\title{
INL Seismic Monitoring Report: January 1, 2013 - December 31, 2013
}

S. J. Payne, B. M. Bockholt, J. M. Hodges, and R. G. Berg

December 2016

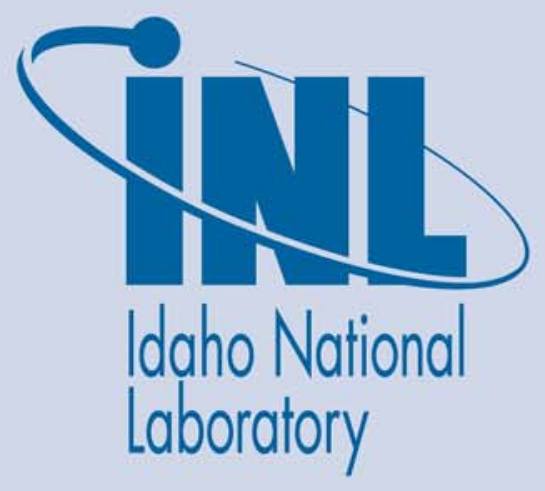

The INL is a U.S. Department of Energy National Laboratory operated by Battelle Energy Alliance 


\section{DISCLAIMER}

This information was prepared as an account of work sponsored by an agency of the U.S. Government. Neither the U.S. Government nor any agency thereof, nor any of their employees, makes any warranty, expressed or implied, or assumes any legal liability or responsibility for the accuracy, completeness, or usefulness, of any information, apparatus, product, or process disclosed, or represents that its use would not infringe privately owned rights. References herein to any specific commercial product, process, or service by trade name, trade mark, manufacturer, or otherwise, does not necessarily constitute or imply its endorsement, recommendation, or favoring by the U.S. Government or any agency thereof. The views and opinions of authors expressed herein do not necessarily state or reflect those of the U.S. Government or any agency thereof. 


\section{INL Seismic Monitoring Report: January 1, 2013 - December 31, 2013}

S. J. Payne, B.M. Bockholt, J. M. Hodges, and R. G. Berg

December 2016

Idaho National Laboratory

Engineering Analysis

Idaho Falls, Idaho 83415

http://www.inl.gov

Prepared for the

U.S. Department of Energy

Office of Nuclear Energy, Science, and Technology

Under DOE Idaho Operations Office

Contract DE-AC07-05ID14517 


\section{SUMMARY}

During 2013, the Idaho National Laboratory (INL) recorded 14,011 independent triggers and 7,355 triggers were manmade blasts and distant, regional, and local earthquakes. Within the region, the INL Seismic Monitoring program located 2,085 earthquakes and 150 man-made blasts. Near and within the $161-\mathrm{km}$ radius of INL, 38 of these earthquakes had small to moderate size magnitudes that ranged from 3.0 to 4.2. Residents near 19 of the $\mathrm{M}>3.0$ earthquakes reported ground shaking affects of these earthquakes to the U.S. Geological Survey. Also, five new seismic stations with broadband seismometers and accelerometers were installed near INL facility areas. These new stations were installed to collect earthquake data that can be used in future INL probabilistic seismic hazard analyses to reduce uncertainties of ground motion models.

In 2013, 1,013 earthquakes were located within the $161-\mathrm{km}$ radius of INL and three occurred within the eastern Snake River Plain (ESRP). The earthquakes included three swarms and a mainshock-aftershock sequence. The earthquakes were located northwest of the INL in the Basin and Range regions of Idaho and Montana and southeast of the ESRP in the Basin and Range region along the Idaho-Wyoming border. A swarm of $>180$ earthquakes occurred at Driggs, Idaho; the largest events had local magnitudes $\left(\mathrm{M}_{\mathrm{L}}\right)$ of 2.8 and 3.1 and were felt by residents. A less intense swarm of 64 earthquakes was located west of Jackson, Wyoming along the Idaho-Wyoming border. The largest event was a $\mathrm{M}_{\mathrm{W}} 3.8$ that was felt by local residents. Southeast of Pocatello, Idaho an earthquake of $\mathrm{M}_{\mathrm{L}} 4.2$ was followed by 18 aftershocks that included a $\mathrm{M}_{\mathrm{L}}$ 3.6. Both earthquakes were felt by residents near the epicenters.

Three earthquakes occurred within the ESRP and three other earthquakes were located at the northwest edge of the ESRP. The coda magnitude $\left(\mathrm{M}_{\mathrm{c}}\right) 1.3$ earthquake was located in the center of ESRP north of the Great Rift and at a depth of $45 \mathrm{~km}$. To the west, an earthquake of $\mathrm{M}_{\mathrm{c}} 0.7$ was located at a depth of $37 \mathrm{~km}$ and at the northwestern end of the Great Rift. Four earthquakes, $\mathrm{M}_{\mathrm{c}} 0.0$, $\mathrm{M}_{\mathrm{c}} 1.3, \mathrm{M}_{\mathrm{c}} 1.8$, and $\mathrm{M}_{\mathrm{c}} 1.1$ were located north of the INL along the edge of the ESRP. The $M_{c} 0.0$ and 1.1 earthquakes were located just within the ESRP at depths less than $6 \mathrm{~km}$. 


\section{ACKNOWLEDGEMENTS}

We appreciate the help of Debra Bruhn, Alex George, and Jonathan Pullum who performed earthquake analysis. We also thank staff at the University of Utah Seismograph Stations, U. S. Geological Survey, and Montana Bureau of Mines and Geology for their earthworm data shares. We also appreciate the support of Incorporated Research Institutions in Seismology (IRIS). The research was funded by the Idaho National Laboratory through the U.S. Department of Energy Idaho Operations Office contract DE-AC07-05ID14517. 


\section{CONTENTS}

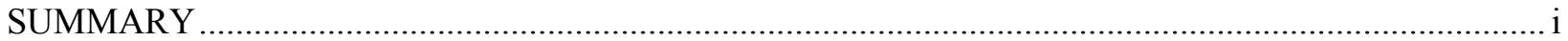

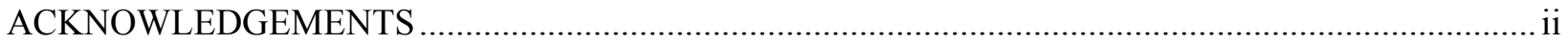

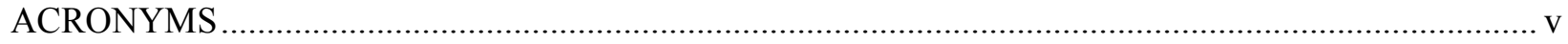

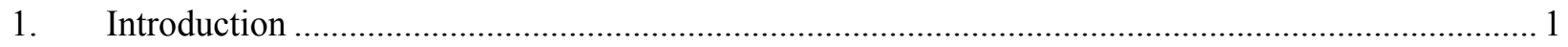

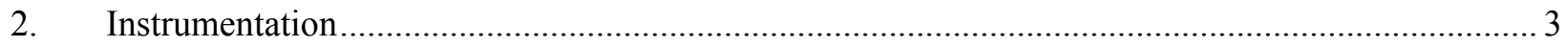

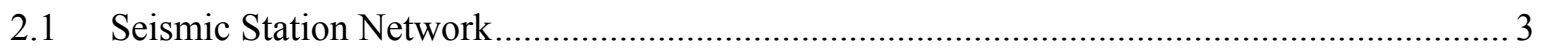

2.1.1 Instrumentation at Short Period Seismic Stations ................................................. 3

2.1.2 Instrumentation at Broadband Seismic Stations ................................................... 9

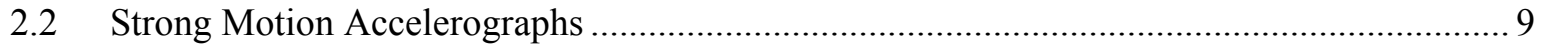

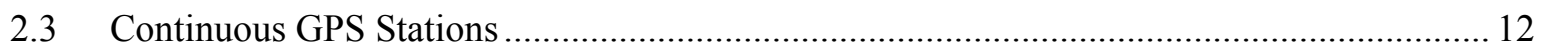

2.4 Seismic Data Acquisition and Analysis System …...................................................... 12

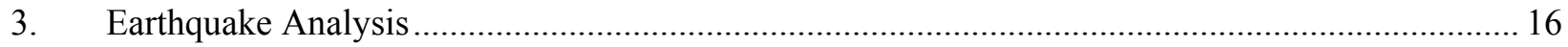

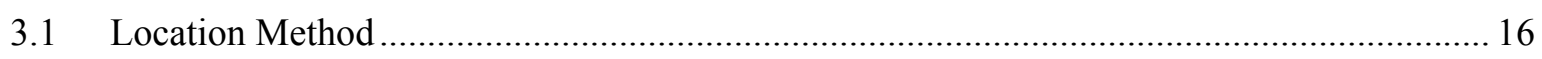

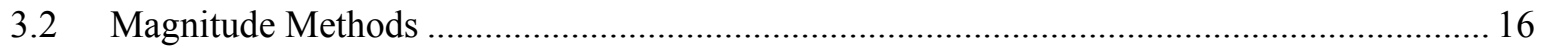

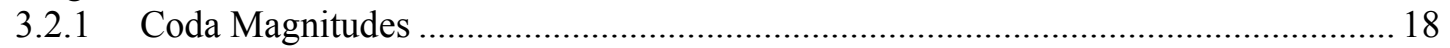

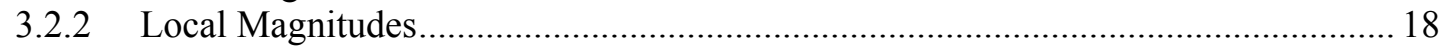

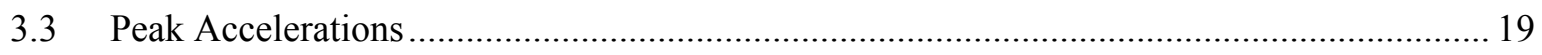

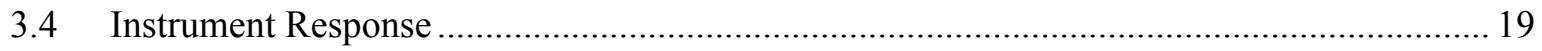

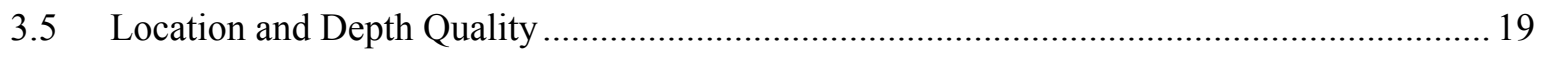

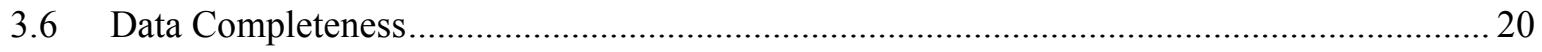

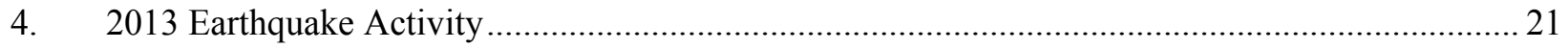

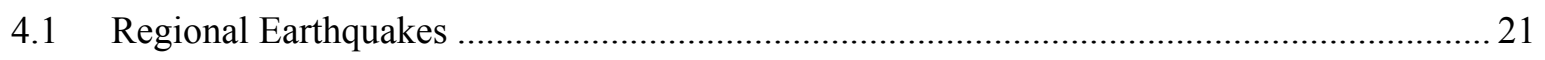

4.2 Earthquakes within 161-km Radius of INL ................................................................ 21

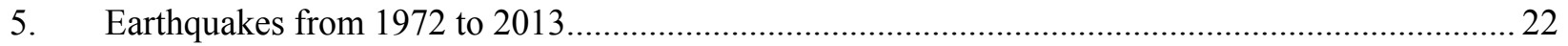

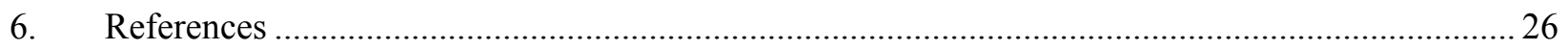

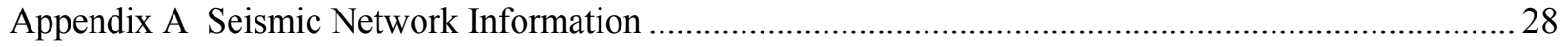

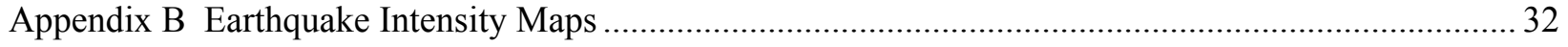

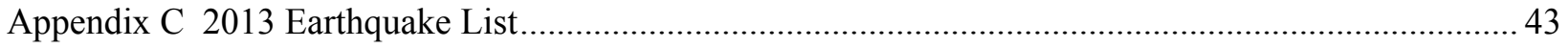




\section{FIGURES}

Figure 1. Map shows locations of the earthquake reporting area within a 161-km (or 100-mile) radius around the INL, Quaternary faults, and volcanic rift zones: G - Great Rift, A Arco, $\mathrm{H}$ - Howe-East Butte, and L - Lava Ridge-Hell's Half Acre.

Figure 2. Map shows the locations of INL seismic stations and stations monitored by INL that are operated by other institutions. Stations BMO and BWO6 are not shown (see Table 2 for locations).

Figure 3. Map shows locations of strong motion accelerograph (SMA) and accelerometer sites at INL.

Figure 4. Map shows locations of continuous GPS stations co-located at INL seismic stations and those operated by the Plate Boundary Observatory (PBO) under the EarthScope Science Program. See Figure 1 for names of normal faults and volcanic rift zones.

Figure 5. Map of earthquakes with magnitudes greater than 3.0 occurring during 2013. Normal fault abbreviations include: BHF - Beaverhead; LHF - Lemhi; LRF - Lost River; and MDF - Madison.

Figure 6. Map of epicenters of earthquakes within the 161-km radius around the INL from January 1, 2013 to December 31, 2013. Normal fault abbreviations include: BHF Beaverhead; LHF - Lemhi; LRF - Lost River; and MDF - Madison

Figure 7. Map of epicenters of earthquakes from 1972 to 2013 within the $161-\mathrm{km}$ (100 mile) radius around the INL

\section{TABLES}

Table 1. Seismic stations operated by INL in 2013. .5

Table 2. Agencies and stations from which INL receives data shares................................................ 8

Table 3. Strong-motion accelerographs and seismic stations with accelerometers operating in 2013.

Table 4. Continuous GPS sites co-located with INL seismic stations. 14

Table 5. P-wave velocity models used in location programs. 17 


\section{ACRONYMS}

\begin{tabular}{|c|c|}
\hline ANL & Argonne National Laboratory \\
\hline ATR & Advanced Test Reactor \\
\hline CFA & Central Facilities Area \\
\hline $\mathrm{COM}$ & Craters of the Moon National Monument and Preserve \\
\hline DAAS & Data Acquisition/Analysis System \\
\hline DOE & U.S. Department of Energy \\
\hline DSL & Digital Subscriber Line \\
\hline EFS & Experimental Field Station \\
\hline ESRP & Eastern Snake River Plain \\
\hline GPS & Global Positioning System \\
\hline ICPP & Idaho Chemical Processing Plant \\
\hline IF & Idaho Falls \\
\hline INL & Idaho National Laboratory \\
\hline INTEC & Idaho Nuclear Technology and Engineering Center \\
\hline IP & Internet Protocol \\
\hline IRC & INL Research Center \\
\hline LOFT & Loss of Fluid Test \\
\hline LTA & Long Term Average \\
\hline MFC & Materials and Fuels Complex \\
\hline $\mathrm{M}_{\mathrm{c}}$ & Coda Magnitude \\
\hline $\mathrm{M}_{\mathrm{L}}$ & Local Magnitude \\
\hline $\mathrm{M}_{\mathrm{s}}$ & Surface-wave Magnitude \\
\hline $\mathrm{M}_{\mathrm{W}}$ & Moment Magnitude \\
\hline NEIC & National Earthquake Information Center \\
\hline NRF & Naval Reactor Facility \\
\hline
\end{tabular}




$\begin{array}{ll}\text { OFS } & \text { Old Fire Station } \\ \text { PBF } & \text { Power Burst Facility } \\ \text { PBO } & \text { Plate Boundary Observatory } \\ \text { PDCC } & \text { Portable Data Collection Center } \\ \text { PSHA } & \text { Probabilistic Seismic Hazard Analysis } \\ \text { P-Wave } & \text { Compression Wave } \\ \text { REC } & \text { Research and Education Campus } \\ \text { RMS } & \text { Root Mean Square } \\ \text { RWMC } & \text { Radioactive and Waste Management Complex } \\ \text { SEED } & \text { Standard for the Exchange of Earthquake Data } \\ \text { SMA } & \text { Strong Motion Accelerograph } \\ \text { SMC } & \text { Special Manufacturing Complex } \\ \text { SSCs } & \text { Structures, Systems, and Components } \\ \text { STA } & \text { Short Term Average } \\ \text { S-Wave } & \text { Shear Wave } \\ \text { TAN } & \text { Test Area North } \\ \text { TG } & \text { Teledyne Geotech } \\ \text { TRA } & \text { Test Reactor Area } \\ \text { USGS } & \text { United States Geological Survey } \\ \end{array}$




\section{INL Seismic Monitoring Report: January 1, 2013 to December 31, 2013}

\section{Introduction}

The INL Seismic Monitoring Program provides the Idaho National Laboratory (INL) with earthquake data and staff expertise to support the requirements set forth by Presidential executive orders, U.S. Department of Energy (DOE) directives, orders and standards, and the Nuclear Regulatory Commission for seismic safety. Seismic monitoring is required by DOE Order 420.1C "Facility Safety" (DOE, 2012). The program supports safety of: Structures, Systems, and Components (SSCs); workers and the public; and operations for INL nuclear facilities and waste management activities. The program supports safety of operations through continuous monitoring of earthquake activity, the incorporation of earthquake data into INL probabilistic seismic hazard analyses (PSHAs), the development of INL seismic design criteria, and early warning of volcanic-related earthquakes as an indicator of potential volcanic activity near INL. For example, five new seismic stations were installed in 2013 at INL facility areas to record local earthquakes that can be used in future PSHAs to assess near surface site effects and other parameters that characterize ground motion models.

The INL Seismic Monitoring Program operates 32 permanent seismic stations for the purpose of determining the time, location, and size of earthquakes occurring in the vicinity of the INL. The seismic data are compiled to develop an historical database that defines the spatial distributions, earthquake magnitudes, and frequencies of earthquakes. The INL seismic network has stations that are located on the INL, within the eastern Snake River Plain (ESRP), and in the surrounding mountains or Basin and Range regions. INL seismic stations are located near sources of future earthquakes including Quaternary normal faults, volcanic rift zones, and the ESRP (Figure 1). Additionally, Global Positioning System (GPS) receivers are co-located at 16 seismic stations for the purpose of determining rates of crustal deformation. GPS velocity gradients are used to identify regions with higher crustal deformation rates (such as Yellowstone Caldera in Wyoming) relative to regions with lower deformation rates (e.g., Snake River Plain, Idaho). Regions with high deformation rates generally have higher rates of earthquakes.

The INL Seismic Monitoring Program also operates 30 sites that have strong motion accelerographs (SMAs) or three-component accelerometers for the purpose of recording strong ground motions from local moderate or major earthquakes. Ten SMAs are located in INL buildings to determine the response of these buildings to ground motions in the event of a large earthquake. Seven SMAs at "free-field" sites (not within buildings) located at INL facility areas are used to determine levels of ground shaking for either rock or soil conditions. Two other sites have SMAs and eleven sites have three-component accelerometers, all of which are co-located at INL seismic stations to record acceleration data and assess ground motions from small to large magnitude normal faulting earthquakes.

This report covers the earthquake activity from January 1, 2013 through December 31, 2013 and is a continuation of previous annual reports on earthquake activity in ESRP within and near the INL and adjacent Basin and Range regions. The INL has accumulated 41 years of earthquake data (1972-2013). This report discusses seismic station, SMA, and continuous GPS instrumentation used to record the earthquake data and how these data are analyzed. It also discusses earthquake activity that has occurred around the local region and within a $161-\mathrm{km}$ (or 100-mile) radius of the INL from the center point of $43^{\circ}$ $39.00^{\prime} \mathrm{N}, 112^{\circ} 47.00^{\prime} \mathrm{W}$ (Figure 1). 


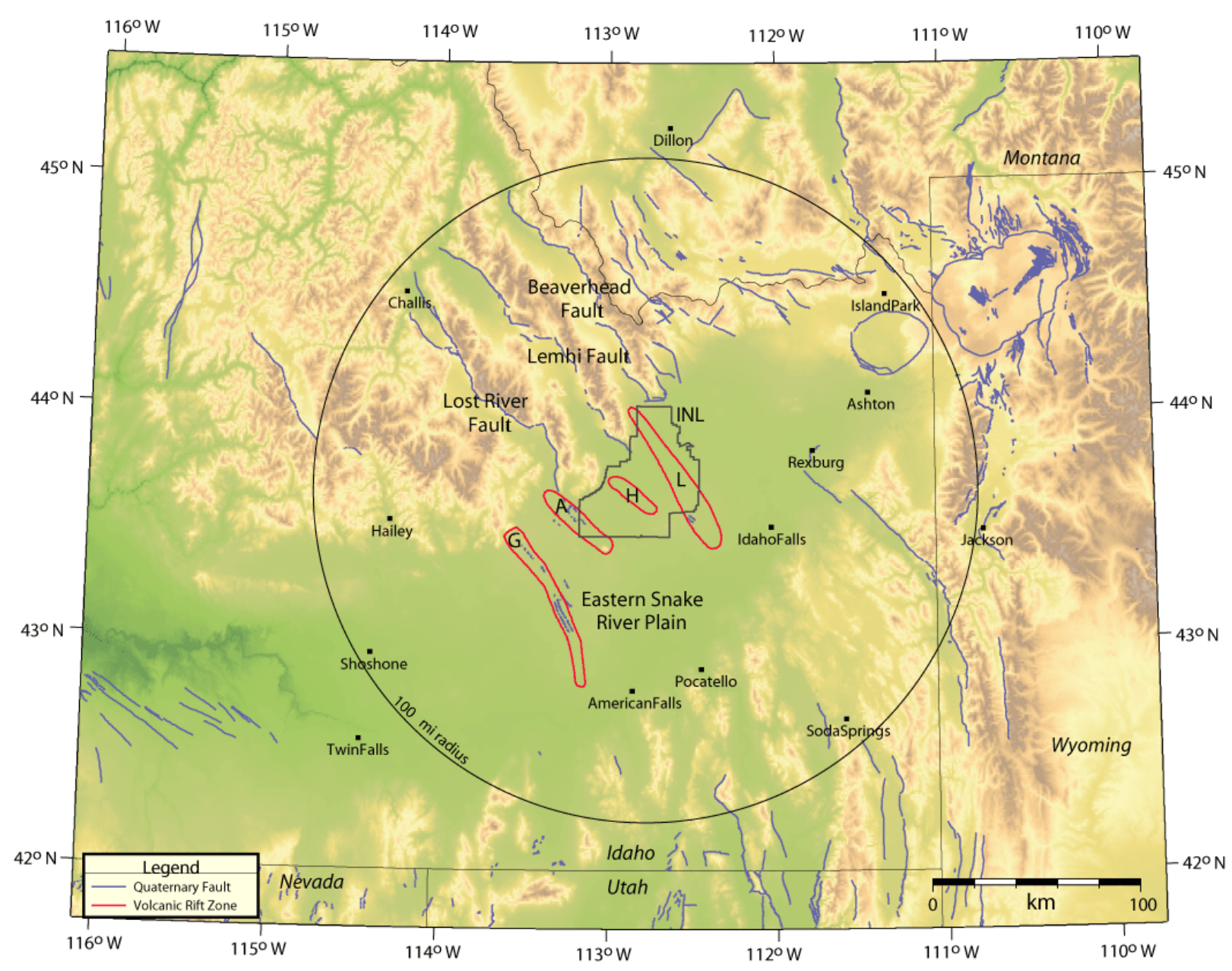

Figure 1. Map shows locations of the earthquake reporting area within a 161-km (or 100-mile) radius around the INL, Quaternary faults, and volcanic rift zones: G - Great Rift, A - Arco, H - Howe-East Butte, and L - Lava Ridge-Hell's Half Acre. 


\section{Instrumentation}

The INL Seismic Monitoring program acquires earthquake data from a network of seismic stations and SMAs which is recorded on the program's Data Acquisition/Analysis System (DAAS). INL operates a seismic network of 32 stations and records data from nearby seismic stations operated by other agencies. The INL seismic network has had various configurations of seismic stations since 1972 and that history is discussed in Section A-1 (Appendix A). Section 2.1 covers the current configuration of seismic stations that operated in 2013 and the associated instrumentation including GPS receivers (Section 2.3). The INL also operates 30 sites with SMAs and three-component accelerometers. SMAs were first installed in the 1970's at INL and their facility locations have evolved over time based on the needs of facility operations as discussed in Section A-2 (Appendix A). Section 2.2 discusses the instrumentation at SMA sites and accelerometers co-located at seismic stations that operated in 2013. Earthquake data are transmitted from seismic stations and some SMA sites to the DAAS, which is located in Idaho Falls, Idaho (Section 2.4).

\subsection{Seismic Station Network}

During 2013, the INL Seismic Monitoring Program operated 32 permanent seismic stations and monitored up to 24 seismic stations from other nearby seismic networks (Figure 2). Five new seismic stations were installed in September of 2013 at sites on INL. These new seismic stations were installed to record local and regional earthquakes that can be used in future PSHAs to assess near surface site effects and other parameters that characterize site-specific ground motion models at INL facility areas (Payne et al., 2012a). Table 1 lists the name, location, date of installation, and instrumentation for all of the seismic stations owned and operated by the INL Seismic Monitoring Program. Table 2 lists the name, location, and operation dates of seismic stations owned by other agencies. The INL recorded seismic data from these other seismic stations to improve the quality of earthquake locations within the 161-km radius of INL.

For monitoring continuous earthquake data, an INL seismic station is composed of a seismometer, data logger, digital radio, and DC power sources. Seismic stations have one to three seismometers. Some stations have a single, vertically oriented short-period seismometer whereas other stations have a threecomponent broadband seismometer with a vertical and two orthogonal horizontal components. Stations with three sensors have a short-period vertical seismometer and two short period, orthogonally oriented horizontal seismometers (Table 1). INL seismic stations have seismometers installed in surface vaults that are on rock or soil deposits. Some stations have seismometers installed in rock at the base of $18-\mathrm{m}$ or greater boreholes. Seismic signals from the seismometers are digitized using a data logger at the station. The instrumentation at the seismic stations is powered by batteries, solar panels, and at some locations, small wind generators. Since INL seismic stations are remotely located, digitized seismic signals are relayed by digital radios or internet Digital Subscriber Line (DSL) links to the DAAS computers located in Idaho Falls (Section A-3 in Appendix A). The DSL sites in Arco, Idaho, Howe, Idaho, and at Gray's Lake near Wayan, Idaho each have a computer that provides data to the data acquisition computer in Idaho Falls via the internet.

\subsubsection{Instrumentation at Short Period Seismic Stations}

Instrumentation for short-period INL seismic stations consists of one or two types of short period seismometers with a DAQSystems NetDAS digital data logger. Single-component short-period seismic stations have vertically oriented seismometers that are a Mark Products model L-4C, Teledyne Geotech (TG) model S-13, or TG model S-13 Jr. seismometer. Some short-period seismic stations have two Teledyne Geotech model S-13 horizontal seismometers located in surface vaults along with the verticallyoriented seismometer. All seismic stations located within the ESRP have their vertical short period seismometer located at the base of the 18-m or greater borehole to help dampen wind and cultural noise. Short period seismometers at stations outside of the ESRP are buried within $3 \mathrm{~m}$ of the ground surface. 


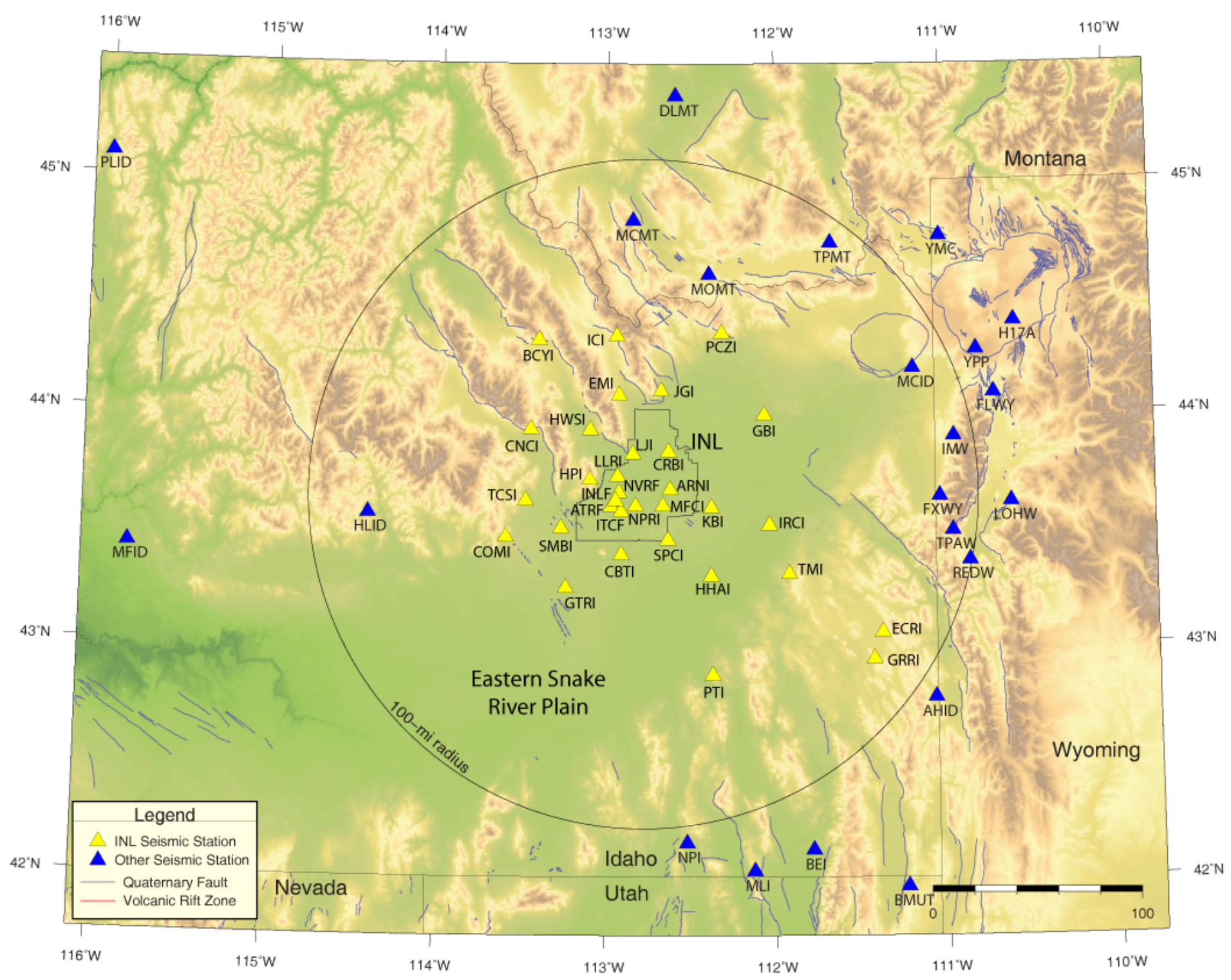

Figure 2. Map shows the locations of INL seismic stations and stations monitored by INL that are operated by other institutions. Stations BMO and BWO6 are not shown (see Table 2 for locations). 
Table 1. Seismic stations operated by INL in 2013.

\begin{tabular}{|c|c|c|c|c|c|c|}
\hline Code & Station Name & Types of Sensors & $\begin{array}{l}\text { Latitude } \\
\text { North } \\
\left({ }^{\circ}\right)\end{array}$ & $\begin{array}{l}\text { Longitude } \\
\text { West } \\
\left({ }^{\circ}\right) \\
\end{array}$ & $\begin{array}{c}\text { Elevation } \\
(\mathrm{m})\end{array}$ & $\begin{array}{c}\text { Date } \\
\text { Installed } \\
\text { (Month/Year) } \\
\end{array}$ \\
\hline ARNI & $\begin{array}{l}\text { Argonne North, } \\
\text { Idaho }\end{array}$ & $\begin{array}{l}\text { Borehole Vertical } \\
\text { Seismometer; } \\
\text { GPS Receiver }\end{array}$ & 43.6667 & 112.6235 & 1533 & 09/1990 \\
\hline ATRF & $\begin{array}{l}\text { Advanced Test } \\
\text { Reactor, Idaho }\end{array}$ & $\begin{array}{l}\text { Three-component } \\
\text { Broadband Seismometer; } \\
\text { Three-component } \\
\text { Accelerometer }\end{array}$ & 43.5952 & 112.9724 & 1502 & $09 / 2013$ \\
\hline BCYI & $\begin{array}{l}\text { Bear Canyon, } \\
\text { Idaho }\end{array}$ & $\begin{array}{l}\text { Vertical Seismometer; } \\
\text { Three-component } \\
\text { Accelerometers; } \\
\text { GPS Receiver }\end{array}$ & 44.3108 & 113.4052 & 2194 & 05/1992 \\
\hline CBTI & $\begin{array}{l}\text { Cedar Butte, } \\
\text { Idaho }\end{array}$ & $\begin{array}{l}\text { Borehole Vertical } \\
\text { Seismometer }\end{array}$ & 43.3875 & 112.9115 & 1734 & $07 / 1986$ \\
\hline COMI & $\begin{array}{l}\text { Craters of the } \\
\text { Moon, Idaho }\end{array}$ & $\begin{array}{l}\text { Three-component } \\
\text { Seismometers; Strong- } \\
\text { Motion Accelerograph }\end{array}$ & 43.4618 & 113.5938 & 1890 & 03/1992 \\
\hline $\mathrm{CNCI}$ & $\begin{array}{l}\text { Crows Nest } \\
\text { Canyon, Idaho }\end{array}$ & $\begin{array}{l}\text { Vertical (Short-period) } \\
\text { Seismometer; Three- } \\
\text { component Broadband } \\
\text { Seismometer }\end{array}$ & 43.9283 & 113.4522 & 1914 & 05/1992 \\
\hline CRBI & $\begin{array}{l}\text { Circular Butte, } \\
\text { Idaho }\end{array}$ & $\begin{array}{l}\text { Borehole Vertical } \\
\text { Seismometer; } \\
\text { GPS Receiver }\end{array}$ & 43.8303 & 112.6345 & 1520 & $11 / 1987$ \\
\hline ECRI & $\begin{array}{l}\text { Eagle Creek, } \\
\text { Idaho }\end{array}$ & Vertical Seismometer & 43.0535 & 111.3705 & 2086 & 08/1994 \\
\hline EMI & $\begin{array}{l}\text { Eightmile } \\
\text { Canyon, Idaho }\end{array}$ & $\begin{array}{l}\text { Vertical Seismometer; } \\
\text { GPS Receiver }\end{array}$ & 44.0742 & 112.9262 & 1963 & 04/1992 \\
\hline GBI & $\begin{array}{l}\text { Big Grassy } \\
\text { Butte, Idaho }\end{array}$ & $\begin{array}{l}\text { Borehole Vertical } \\
\text { Seismometer; } \\
\text { GPS Receiver }\end{array}$ & 43.9875 & 112.0633 & 1541 & $10 / 1981$ \\
\hline GRRI & $\begin{array}{l}\text { Grays Range, } \\
\text { Idaho }\end{array}$ & $\begin{array}{l}\text { Vertical Seismometer; } \\
\text { Three-component } \\
\text { Accelerometer; } \\
\text { GPS Receiver }\end{array}$ & 42.9380 & 111.4217 & 2207 & 08/1994 \\
\hline GTRI & Great Rift, Idaho & $\begin{array}{l}\text { Borehole Vertical } \\
\text { Seismometer; } \\
\text { GPS Receiver }^{1}\end{array}$ & 43.2440 & 113.2410 & 1522 & 05/1992 \\
\hline HHAI & $\begin{array}{l}\text { Hell's Half Acre, } \\
\text { Idaho }\end{array}$ & $\begin{array}{l}\text { Borehole Vertical } \\
\text { Seismometer }\end{array}$ & 43.2950 & 112.3795 & 1371 & 06/1992 \\
\hline
\end{tabular}


Table 1. Continued.

\begin{tabular}{|c|c|c|c|c|c|c|}
\hline Code & Station Name & Types of Sensors & $\begin{array}{l}\text { Latitude } \\
\text { North } \\
\left(^{\circ}\right)\end{array}$ & $\begin{array}{l}\text { Longitude } \\
\text { West } \\
\left({ }^{\circ}\right)\end{array}$ & $\begin{array}{l}\text { Elevation } \\
\quad(\mathrm{m})\end{array}$ & $\begin{array}{c}\text { Date } \\
\text { Installed } \\
\text { (Month/Year) }\end{array}$ \\
\hline HPI & $\begin{array}{l}\text { Howe Peak, } \\
\text { Idaho }\end{array}$ & $\begin{array}{l}\text { Vertical Seismometer; } \\
\text { GPS Receiver }\end{array}$ & 43.7113 & 113.0983 & 2597 & $10 / 1972$ \\
\hline HWFI & $\begin{array}{l}\text { Howe Fault, } \\
\text { Idaho }\end{array}$ & $\begin{array}{l}\text { Three-component } \\
\text { Seismometers; Three- } \\
\text { component Accelerometer; } \\
\text { GPS Receiver }\end{array}$ & 43.9257 & 113.0973 & 1743 & 10/1999 \\
\hline ICI & $\begin{array}{l}\text { Italian Canyon, } \\
\text { Idaho }\end{array}$ & $\begin{array}{l}\text { Vertical Seismometer; } \\
\text { GPS Receiver }\end{array}$ & 44.3293 & 112.9412 & 2463 & 04/1992 \\
\hline INLF & $\begin{array}{l}\text { INEL-1 Drill } \\
\text { Site, Idaho }\end{array}$ & $\begin{array}{l}\text { Three-component } \\
\text { Broadband Seismometer; } \\
\text { Three-component } \\
\text { Accelerometer }\end{array}$ & 43.6206 & 112.9466 & 1476 & $08 / 2013$ \\
\hline IRCI & $\begin{array}{l}\text { INL Research } \\
\text { Center, Idaho }\end{array}$ & $\begin{array}{l}\text { Low-gain Three- } \\
\text { component Seismometers }\end{array}$ & 43.5153 & 112.0333 & 1442 & $11 / 1988$ \\
\hline ITCF & $\begin{array}{l}\text { Idaho Nuclear } \\
\text { and Engineering } \\
\text { Technology } \\
\text { Complex, Idaho }\end{array}$ & $\begin{array}{l}\text { Three-component } \\
\text { Broadband Seismometer; } \\
\text { Three-component } \\
\text { Accelerometer }\end{array}$ & 43.5716 & 112.9148 & 1490 & $09 / 2013$ \\
\hline JGI & $\begin{array}{l}\text { Juniper Gulch, } \\
\text { Idaho }\end{array}$ & $\begin{array}{l}\text { Three-component } \\
\text { Seismometer }\end{array}$ & 44.0927 & 112.6768 & 1657 & $11 / 1979$ \\
\hline KBI & $\begin{array}{l}\text { Kettle Butte, } \\
\text { Idaho }\end{array}$ & $\begin{array}{l}\text { Borehole Vertical } \\
\text { Seismometer }\end{array}$ & 43.5907 & 112.3767 & 1678 & $05 / 1992$ \\
\hline LJI & $\begin{array}{l}\text { Lemhi Junction, } \\
\text { Idaho }\end{array}$ & Vertical Seismometer & 43.8208 & 112.8440 & 1643 & $05 / 1990$ \\
\hline LLRI & $\begin{array}{l}\text { Little Lost } \\
\text { River, Idaho }\end{array}$ & $\begin{array}{l}\text { Three-component } \\
\text { Seismometer; } \\
\text { GPS Receiver }\end{array}$ & 43.7230 & 112.9330 & 1476 & 05/1990 \\
\hline $\mathrm{MFCF}$ & $\begin{array}{l}\text { Materials and } \\
\text { Fuels Complex, } \\
\text { Idaho }\end{array}$ & $\begin{array}{l}\text { Three-component } \\
\text { Broadband Seismometer; } \\
\text { Three-component } \\
\text { Accelerometer }\end{array}$ & 43.5966 & 112.6653 & 1583 & $09 / 2013$ \\
\hline NPRI & $\begin{array}{l}\text { New Production } \\
\text { Reactor, Idaho }\end{array}$ & $\begin{array}{l}\text { Three-component Short- } \\
\text { period and Broadband } \\
\text { Seismometers; Three- } \\
\text { component Accelerometer; } \\
\text { GPS Receiver }\end{array}$ & 43.5975 & 112.8272 & 1495 & $09 / 1990$ \\
\hline NVRF & $\begin{array}{l}\text { Naval Reactors } \\
\text { Facility, Idaho }\end{array}$ & $\begin{array}{l}\text { Three-component } \\
\text { Broadband Seismometer; } \\
\text { Three-component } \\
\text { Accelerometer }\end{array}$ & 43.6541 & 112.9279 & 1489 & $09 / 2013$ \\
\hline
\end{tabular}


Table 1. Continued.

\begin{tabular}{|c|l|l|c|c|c|c|}
\hline Code & \multicolumn{1}{|c|}{ Station Name } & \multicolumn{1}{|c|}{ Types of Sensors } & $\begin{array}{c}\text { Latitude } \\
\text { North } \\
\left({ }^{\circ}\right)\end{array}$ & $\begin{array}{c}\text { Longitude } \\
\text { West } \\
\left({ }^{\circ}\right)\end{array}$ & $\begin{array}{c}\text { Elevation } \\
(\mathrm{m})\end{array}$ & $\begin{array}{c}\text { Date } \\
\text { Installed } \\
(\text { Month/Year })\end{array}$ \\
\hline PTI & Pocatello, Idaho & $\begin{array}{l}\text { Vertical Seismometer; } \\
\text { Three-component } \\
\text { Accelerometer; } \\
\text { GPS Receiver }\end{array}$ & 42.8703 & 112.3702 & 1670 & $10 / 1984$ \\
\hline PZCI & $\begin{array}{l}\text { Patelzick Creek, } \\
\text { Idaho }\end{array}$ & $\begin{array}{l}\text { Vertical Seismometer; } \\
\text { GPS Receiver }\end{array}$ & 44.3410 & 112.3172 & 2073 & $12 / 1991$ \\
\hline SMBI & $\begin{array}{l}\text { Sixmile Butte, } \\
\text { Idaho }\end{array}$ & $\begin{array}{l}\text { Borehole Vertical } \\
\text { Seismometer }\end{array}$ & 43.5022 & 113.2677 & 1716 & $05 / 1992$ \\
\hline SPCI & $\begin{array}{l}\text { Split Crater, } \\
\text { Idaho }\end{array}$ & $\begin{array}{l}\text { Three-component } \\
\text { Seismometer; Three- } \\
\text { component Accelerometer }\end{array}$ & 43.4500 & 112.6370 & 1553 & $06 / 1992$ \\
\hline TCSI & $\begin{array}{l}\text { Telchick Spring, } \\
\text { Idaho }\end{array}$ & $\begin{array}{l}\text { Vertical Seismometer; } \\
\text { GPS Receiver }\end{array}$ & 43.6193 & 113.4783 & 1731 & $05 / 1992$ \\
\hline TMI & $\begin{array}{l}\text { Taylor } \\
\text { Mountain, Idaho }\end{array}$ & $\begin{array}{l}\text { Three-component } \\
\text { Seismometer; } \\
\text { GPS Receiver }\end{array}$ & 43.3057 & 111.9182 & 2179 & $10 / 1972$ \\
\hline 1. - GPS instrumentation is owned by the Plate Boundary Observatory under the EarthScope Science Program.
\end{tabular}


Table 2. Agencies and stations from which INL receives data shares.

\begin{tabular}{|c|c|c|c|c|}
\hline Code & Station Name & Latitude North $\left({ }^{\circ}\right)$ & Longitude West $\left(^{\circ}\right)$ & Elevation (m) \\
\hline \multicolumn{5}{|c|}{ National Earthquake Information Center, Golden, Colorado } \\
\hline AHID & Auburn, Idaho & 42.7653 & 111.1003 & 1960 \\
\hline $\mathrm{BMO}$ & Baker City, Oregon & 44.8525 & 117.3060 & 1154 \\
\hline BW06 & Boulder, Wyoming & 42.7667 & 109.5582 & 2224 \\
\hline DLMT & Dillon, MT & 45.3625 & 112.5964 & 1569 \\
\hline FLWY & Flagg Ranch, WY & 44.0827 & 110.6993 & 2078 \\
\hline FXWY & Fox Creek, WY & 43.6381 & 111.0268 & 2254 \\
\hline HLID & Hailey, Idaho & 43.5625 & 114.4063 & 1498 \\
\hline IMW & Indian Meadows, Wyoming & 43.8970 & 110.9392 & 2646 \\
\hline LOHW & Long Hollow, Wyoming & 43.6123 & 110.6037 & 2121 \\
\hline MFID & Camas Ranch, Mayfield, ID & 43.4151 & 115.8278 & 1302 \\
\hline PLID & Pearl Lake, ID & 45.0877 & 116.0002 & 2164 \\
\hline REDW & Red Top Meadow, Wyoming & 43.3642 & 110.8518 & 2322 \\
\hline TPAW & Teton Pass, Wyoming & 43.4902 & 110.9507 & 2512 \\
\hline \multicolumn{5}{|c|}{ University of Utah, Salt Lake City, Utah } \\
\hline BEI & Bear River Range, Idaho & 42.1167 & 111.7823 & 1859 \\
\hline BMUT & Black Mountain, Utah & 41.9582 & 111.2342 & 2243 \\
\hline H17A & Transportable Array Site & 44.3951 & 110.5762 & 2400 \\
\hline MCID & Moose Creek, Idaho & 44.1903 & 111.1827 & 2149 \\
\hline MLI & Malad Range, Idaho & 42.0268 & 112.1255 & 1896 \\
\hline NPI & North Pocatello, Idaho & 42.1473 & 112.5183 & 1640 \\
\hline YMC & Maple Creek, Wyoming & 44.7593 & 111.0062 & 2073 \\
\hline YPP & Pitchstone Plateau, Wyoming & 44.2710 & 110.8045 & 2707 \\
\hline \multicolumn{5}{|c|}{ Montana Bureau of Mines and Geology, Butte, Montana } \\
\hline MCMT & McKenzie Canyon, Montana & 44.8277 & 112.8488 & 2323 \\
\hline MOMT & Monida, Montana & 44.5933 & 112.3943 & 2220 \\
\hline TPMT & Teepee Creek, Montana & 44.7298 & 111.6657 & 2518 \\
\hline
\end{tabular}


The DAQSystems NetDAS data logger has an embedded LINUX computer with a GPS clock and Symmetric Research 24-bit digitizer. The NetDAS data logger has from 22 to 24 bits of data resolution over \pm 20 volts for a four-channel unit or \pm 10 volts for an eight-channel unit. Four-channel units (NetDAS-CH4) are located at seismic stations that have one or three seismometers; eight channel units (NetDAS-CH8) are at seismic stations that have one or three seismometers and three-component accelerometers. The NetDAS digitizes data at the seismic station and time stamps the data with accuracies of \pm 0.001 seconds. The seismic signals are transmitted by FreeWave Technologies DGR $115900 \mathrm{MHz}$ Wireless Modem radios. These radios use standard IP (Internet Protocol) networking features that are included in their embedded LINUX operating system. The short period seismic stations transmit their signals to other stations that serve as relay stations. The relay sites transmit multiple seismic signals to the DSL sites at Arco, Howe, and Gray's Lake (Figure A-1 in Appendix A).

\subsubsection{Instrumentation at Broadband Seismic Stations}

Five new seismic stations installed in 2013 and two existing seismic stations have three-component broadband seismometers connected to digital data loggers. Six stations (ATRF, ITCF, INLF, MFCF, NPRI, and NVRF) each have the Nanometrics Trillium T120-PA broadband seismometer and one station (CNCI) has the Guralp CMG-3T three-component broadband seismometer. Each of the three-component broadband seismometers is connected to the Kinemetrics Quanterra Q330 digital data logger. The Quanterra Q330 has six or three channels, a 24-bit digitizer, GPS receiver, and low-power consumption. A Kinementrics Baler PB44 is connected to the Quanterra and is used for data storage at the seismic station and data transmitting. The broadband seismometers and data loggers are housed in a vault-like enclosure which is covered by native soils to dampen wind noise and minimize temperature fluctuations. Seismic stations, CNCI, ITCF, INLF, MFCF, NPRI, and NVRF, have their vaults on rock, and the vault at the ATRF broadband station is on shallow soil (possibly less than $<20 \mathrm{ft}$ ). FreeWave Technologies DGR115 $900 \mathrm{MHz}$ Wireless Modem radios transmit seismic signals from seismic stations CNCI and NPRI. Sierra Wireless, AirLink series cell modems transmit seismic signals from ATRF, ITCF, INLF, MFCF, and NVRF. The broadband seismic signals are transmitted to relay stations or directly to the DSL sites in Arco or Howe (Figure A-1 in Appendix A).

\subsection{Strong Motion Accelerographs}

During 2013, the INL Seismic Monitoring Program operated 30 sites with SMAs and threecomponent accelerometers co-located at INL seismic stations. Table 3 lists the location, code, and date of installation of the accelerometer sites. In September of 2013, five new free-field accelerometer sites were installed at INL facility areas. Three-component accelerometers were co-located in the vaults housing the broadband seismic stations, ATRF, ITCF, INLF, MFCF, and NVRF. Along with the five new free-field sites, 19 SMAs operated in INL buildings or at free-field sites on INL (Figure 3). Seven seismic stations housed SMAs (NPRI and COMI) or three-component accelerometers (BCYI, GRRI, HWSI, PTI, and SPCI) (Tables 1 and 3). During 2013, earthquake data were not recorded on any SMAs located within INL facilities.

Instrumentation for the 30 accelerometer sites includes one of two types of data loggers with the Applied MEMs Inc. model SF2500A or SF3000L tri-axial accelerometer. Three-component MEMs accelerometers co-located at a short period station seismic are connected to the DAQSystems NetDAS digital data logger. MEMs accelerometers co-located with a broadband station are connected to the Quanterra Q330 digital data logger. The accelerometer sites and some SMAs at free-field sites are transmitted by FreeWave Technologies DGR $115900 \mathrm{MHz}$ Wireless Modem radios or Sierra Wireless, AirLink series cell modems. The acceleration data are transmitted to relay stations or directly to the DSL sites at Arco, Howe, or Gray's Lake which are then transmitted via the internet to the data acquisition computer in Idaho Falls (Figure A-1 in Appendix A). 


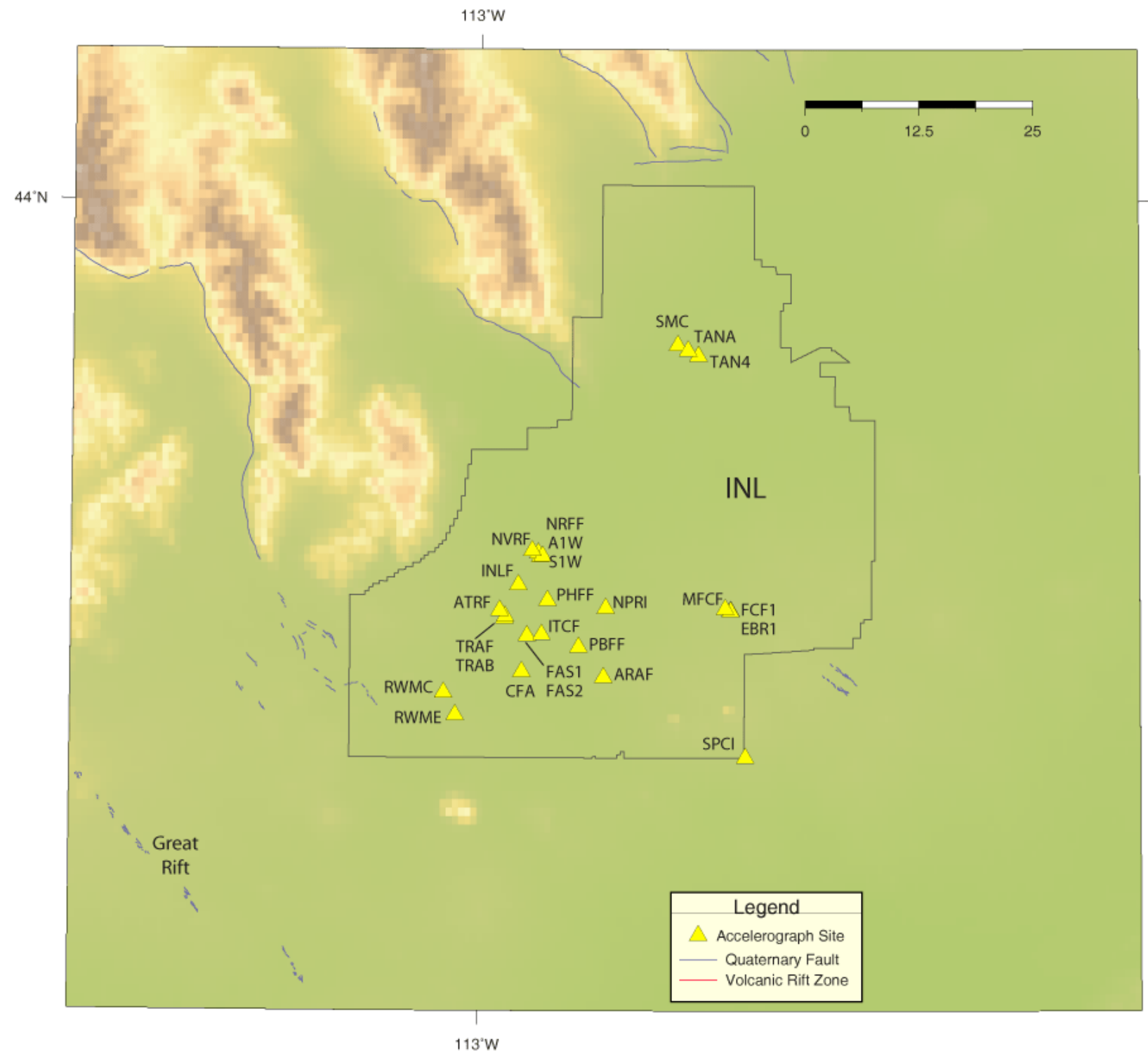

Figure 3. Map shows locations of strong motion accelerograph (SMA) and accelerometer sites at INL. 
Table 3. Strong-motion accelerographs and seismic stations with accelerometers operating in 2013.

\begin{tabular}{|c|c|c|c|c|}
\hline $\begin{array}{c}\text { INL Location } \\
\text { or Seismic Station }\end{array}$ & $\begin{array}{l}\text { Building } \\
\text { Number }\end{array}$ & Location & Site Code & Year Installed \\
\hline ATR & TRA-602 & Free-field & TRAF & 2003 \\
\hline ATR & TRA-670 & Basement & TRAB & 1996 \\
\hline ATRF & NA & Free-field & ATRF & 2013 \\
\hline BCYI & NA & Free-field & BCYI & 2002 \\
\hline CFA & CFA-1607 & Free-field & CFA & 1996 \\
\hline COMI & NA & Free-field & COMF & 2008 \\
\hline EFS & EFS & Free-field & PHFF & 2010 \\
\hline GRRI & NA & Free-field & GRRI & 2002 \\
\hline HWSI & NA & Free-field & HWSI & 2002 \\
\hline INEL-1 & NA & Free-field & INLF & 2013 \\
\hline INTEC & ICPP-666 & Second Floor & FAS1 & 1984 \\
\hline INTEC & ICPP-666 & Second Basement & FAS2 & 1984 \\
\hline INTEC & NA & Free-field & ITCF & 2013 \\
\hline $\mathrm{MFC}$ & ANL-767 & Basement & EBR1 & 1973 \\
\hline MFC & ANL-768 & Basement & FCF1 & 1973 \\
\hline MFC & NA & Free-field & MFCF & 2013 \\
\hline NRF & NRF-768 & Free-field & NRFF & 1996 \\
\hline NRF & NRF-A1W & First Floor & $\mathrm{A} 1 \mathrm{~W}$ & 1983 \\
\hline NRF & NRF-S1W & First Floor & S1W & 1983 \\
\hline $\mathrm{NRF}$ & NA & Free-field & NVRF & 2013 \\
\hline $\mathrm{PBF}$ & NA & Free-field & PBFF & 2005 \\
\hline $\mathrm{PBF}$ & NA & Free-field & ARAF & 2005 \\
\hline PTI & NA & Free-field & PTI & 2003 \\
\hline RWMC & NA & Free-field & RWMC & 1997 \\
\hline RWMC & NA & Free-field & RWME & 2005 \\
\hline REC & IF-602 & First Floor & IRC & 1983 \\
\hline TAN & NA & Free-field & TANA & 2007 \\
\hline TAN & TAN-601 & First Floor & TAN4 & 2008 \\
\hline TAN & SMC & First Floor & $\mathrm{SMC}$ & 2007 \\
\hline SPCI & NA & Free-field & SPCI & 2003 \\
\hline \multicolumn{5}{|c|}{$\begin{array}{l}\text { NA - Not within a building. } \\
\text { Acronyms: ANL - Argonne National Laboratory; ATR - Advanced Test Reactor; CFA - Central Facilities } \\
\text { Area; COMI - Craters of the Moon seismic station (Table 1); ICPP - Idaho Chemical Processing Plant; EFS } \\
\text { - Experimental Field Station; IF - Idaho Falls; INTEC - Idaho Nuclear Technology and Engineering } \\
\text { Center; MFC - Materials and Fuels Complex; NRF - Naval Reactors Facility; PBF - Power Burst Facility; } \\
\text { RWMC - Radioactive and Waste Management Complex; SMC - Special Manufacturing Complex; TAN - } \\
\text { Test Area North; TRA - Test Reactor Area. }\end{array}$} \\
\hline
\end{tabular}


The SMAs are the DAQSystems NetDAS digital data logger that has an Applied MEMS SiFlex model SF2500A or SF3000L tri-axial accelerometer mounted within the unit. Each MEMs accelerometer component of an SMA is set to trigger and record to a compact flash when ground motions exceed $\sim 0.005$ g except for the SMA in the basement of ATR (TRA2) which is set to less than $0.005 \mathrm{~g}$. The SMA record lengths are set for $30 \mathrm{~s}$ of pre- and post-trigger thresholds. The tri-axial accelerometers have two horizontal components oriented in an orthogonal manner, generally aligned in the north-south and eastwest directions. SMAs housed within secure buildings at INL do not have internet access and therefore the earthquake data are recorded to compact flash disks that are later retrieved using a laptop computer.

\subsection{Continuous GPS Stations}

The INL Seismic Monitoring Program has a geodetic network for the purpose of monitoring crustal deformation in support of INL seismic hazards assessments. The network consists of 16 GPS receivers and antennas co-located with INL seismic stations. Table 4 lists the codes, stations, and date of installation of INL GPS sites. As part of the Plate Boundary Observatory (PBO) under the EarthScope Science Program, there are currently 19 other continuous GPS sites near the Snake River Plain (Figure 4). One of these GPS receivers is co-located at INL seismic station (GTRI). In addition to continuously operating GPS sites, INL personnel periodically collect GPS phase data at nearby campaign GPS sites on INL, in the ESRP, and in the surrounding Basin and Range region.

An INL continuous GPS station consists of a Trimble NetRS GPS receiver connected to a Trimble $\mathrm{L} 1 / \mathrm{L} 2$ dual frequency choke ring antenna. The antenna is attached to a $2.4 \mathrm{~m}$ steel rod that is drilled into a rock outcrop to a depth of about $1 \mathrm{~m}$. The NetRS receivers continuously collect GPS phase data (positions of 20 satellites) at 30 seconds intervals. The GPS phase data along with seismic station data are relayed to the DSL sites at Arco, How, or Gray's Lake using digital radios, and they are then accessible via Internet. The phase data are downloaded daily from the Internet and archived by UNAVCO, ${ }^{\mathrm{TM}}$ a non-profit university-governed consortium.

GPS phase data collected by INL's continuous sites or any campaign sites are provided to Dr. Robert King at the Massachusetts Institute of Technology for processing. Dr. King has processed all of INL's GPS phase data acquired up to 2013. He combines INL GPS data with other data in the region to produce horizontal GPS velocity fields that cover the ESRP and surrounding Basin and Range and fields that encompasses the Pacific Northwest.

GPS data are used to investigate active crustal deformation that is on the order of millimeters of movement per year within the ESRP, the surrounding Basin and Range, and Yellowstone Caldera. GPS data help distinguish regions of high velocity gradients (or strain rates) having more frequent damaging earthquakes (e.g., Yellowstone - Hebgen Lake, Montana) from regions of low velocity gradients (e.g., eastern Snake River Plain). The regional spatial patterns of GPS data also help constrain the fundamental geodynamic processes that drive active continental deformation in the western United States. Locally, the horizontal GPS velocities indicate the Basin and Range is rapidly extending at a rate greater than the very slowly deforming Snake River Plain, which is thought to explain its relative low seismicity (e.g., Payne et al. 2012b; Payne et al., 2013).

\subsection{Seismic Data Acquisition and Analysis System}

The INL Seismic Monitoring office is located in the INL Research Center (IRC) building at the Research and Education Campus (REC) in Idaho Falls. The office houses the DAAS, which has evolved since 1991 (see Section A-4; Appendix A). The DAAS is currently composed of five computers. The first computer performs data acquisition using the software package, EARTHWORM, a second computer is used to analyze earthquakes with the software package, SEISAN (see Section 3), and a third computer is used to serve an internal web site. The fourth computer runs the program SWARM which displays digital seismograms on up to four monitors. The fifth computer is a dedicated repository (or Vault) that routinely 
backups files on the acquisition and analysis computers and archives all digital earthquake data after analysis.

EARTHWORM performs two primary functions that include signal discrimination for possible earthquakes and data sharing with other seismic networks. EARTHWORM constantly monitors seismic signals from seismic stations by evaluating the amplitude ratios of the short-term average (STA) divided by the long-term average (LTA) or STA/LTA. This involves comparing the short-term root-mean square (RMS) average (1-s window) of the seismic data to a longer-term RMS average, which is the background noise or voltage level determined over a time interval of $20 \mathrm{~s}$. The program determines that an earthquake has occurred when the STA/LTA ratios for several stations exceed a threshold value.

The earthquake detection module in EARTHWORM is configured to trigger on earthquakes detected by several stations within a subnet. Subnets contain several stations that are likely to detect the same local earthquake. All INL seismic stations usually detect local earthquakes of magnitude 1.5. Subnets are specified for stations in close proximity to each other and their relationship to known earthquake sources. For the ESRP though, a subnet was created for detection of small magnitude $(\mathrm{M}<0.5)$ microearthquakes.

When an earthquake is detected by EARTHWORM, seismograms are saved in a trigger file on the acquisition computer's disk. The trigger file is labeled with a sequential number based on the date and time of the trigger. The analysis computer pulls trigger files from the acquisition computer and puts them into a directory for analysis by a seismologist using SEISAN. The trigger files are entered into the SEISAN database. Each seismogram has $30 \mathrm{~s}$ of pre-event data and $20 \mathrm{~s}$ of post-event data stored within the trigger file. The pre- and post-event durations ensure the entire earthquake waveform is recorded. In some instances, earthquakes have low-amplitudes, emergent compression (P) waves with larger amplitude shear (S) waves. When this occurs EARTHWORM may trigger on the S-waves instead of the P-waves, thus, saving $30 \mathrm{~s}$ of pre-event time allows recording of the P-waves also.

The EARTHWORM software also allows data sharing of seismic stations in near real time over the Internet. INL uses EARTHWORM data shares to transmit data from the Arco, Howe, and Gray's Lake DSL sites to Idaho Falls, and to acquire seismic station data from other networks and to provide INL seismic station data to other networks. The INL provides data from various seismic stations to the University of Utah, Montana Bureau of Mines and Geology, and National Earthquake Information Center (NEIC), which in return provide data to INL (Table 2). EARTHWORM triggers on and records seismic data from INL and these other agencies. Analyzing earthquake data from these other seismic stations in SEISAN expands the azimuth coverage of stations surrounding an earthquake which results in reduced uncertainties of earthquake locations and magnitudes within the 161-km radius of INL. 
Table 4. Continuous GPS sites co-located with INL seismic stations.

\begin{tabular}{|c|c|c|c|c|c|}
\hline Code & Station Name & $\begin{array}{c}\text { Latitude } \\
\text { North } \\
\left({ }^{\circ}\right)\end{array}$ & $\begin{array}{c}\text { Longitude } \\
\text { West } \\
\left({ }^{\circ}\right)\end{array}$ & $\begin{array}{c}\text { Elevation } \\
(\mathrm{m})\end{array}$ & $\begin{array}{c}\text { Year } \\
\text { Installed }\end{array}$ \\
\hline ARNG & Argonne North, Idaho & 43.6667 & 112.6235 & 1533 & 2005 \\
\hline BCYI & Bear Canyon, Idaho & 44.3108 & 113.4052 & 2194 & 2003 \\
\hline CRBG & Circular Butte, Idaho & 43.8303 & 112.6345 & 1520 & $2007^{1}$ \\
\hline EMIG & Eightmile Canyon, Idaho & 44.0742 & 112.9262 & 1963 & 2005 \\
\hline GBIG & Big Grassy Butte, Idaho & 43.9875 & 112.0633 & 1541 & $2007^{1}$ \\
\hline GRRG & Grays Range, Idaho & 42.9380 & 111.4217 & 2207 & $2007^{1}$ \\
\hline GTRG & Great Rift, Idaho & 43.2440 & 113.2410 & 1522 & $1998^{2}$ \\
\hline HPIG & Howe Peak, Idaho & 43.7113 & 113.0983 & 2597 & 2005 \\
\hline HWFG & Howe Fault, Idaho & 43.9257 & 113.0973 & 1743 & $2007^{1}$ \\
\hline ICIG & Italian Canyon, Idaho & 44.3293 & 112.9412 & 2463 & 2007 \\
\hline LLRG & Little Lost River, Idaho & 43.7230 & 112.9330 & 1476 & 2009 \\
\hline NPRG & New Production Reactor, Idaho & 43.5975 & 112.8272 & 1495 & 2009 \\
\hline PTIG & Pocatello, Idaho & 42.8703 & 112.3702 & 1670 & $2007^{1}$ \\
\hline PZCG & Patelzick Creek, Idaho & 44.3410 & 112.3172 & 2073 & $2007^{1}$ \\
\hline $\begin{array}{l}\text { TCSG } \\
\text { TMIG }\end{array}$ & Telchick Spring, Idaho & 43.6193 & 113.4783 & 1731 & 2005 \\
\hline $\begin{array}{l}1 . \text { Although hardware was installed for the GPS receiver in } 2007, \text { the receiver began acquiring phase data in } \\
\text { EarthScope Science Program. }\end{array}$ & Taylor Mountain, Idaho & 43.3057 & 111.9182 & 2179 & $2007^{1}$ \\
\hline
\end{tabular}




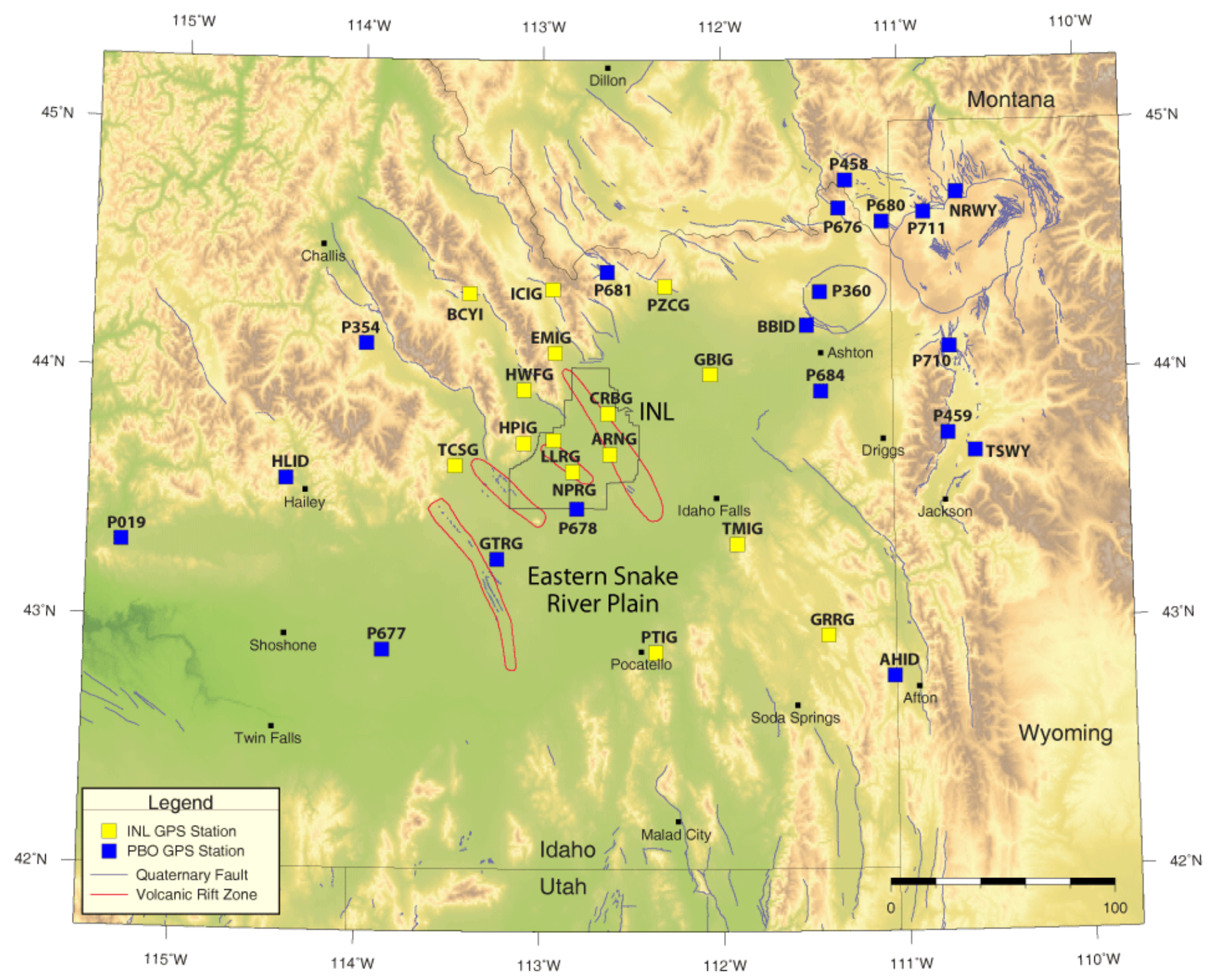

Figure 4. Map shows locations of continuous GPS stations co-located at INL seismic stations and those operated by the Plate Boundary Observatory (PBO) under the EarthScope Science Program. See Figure 1 for names of normal faults and volcanic rift zones. 


\section{Earthquake Analysis}

Digital seismograms are analyzed using the SEISAN program to determine the earthquake's location, magnitude, peak ground accelerations, and instrument responses. SEISAN displays multiple seismograms on a computer screen with corresponding time codes having accuracy of $\pm 0.001 \mathrm{~s}$. P- and S-wave arrival times in the seismograms are selected at an accuracy of up to $\pm 0.01 \mathrm{~s}$. Durations and amplitudes of seismic signals are selected, corrected using instrument responses, and then used to calculate earthquake magnitudes. The arrival times, durations, and amplitudes measured for an earthquake are saved in a computer file directly from the SEISAN program.

Earthquakes are located using the HYPOINVERSE-2000 program (Section 3.1) and two methods may be used to calculate the final magnitude of an earthquake depending on its size (Section 3.2). The locations and magnitudes of the earthquakes are plotted on maps to assess seismically active regions near the INL. When available from a large magnitude earthquake, amplitudes of accelerograms can be measured using the SEISAN program then processed using a separate program to determine peak horizontal and vertical accelerations (Section 3.3). Instrument responses of the data logger and sensors at seismic stations and SMAs are now routinely determined and integrated into the SEISAN database (Section 3.4). Finally, INL discriminates manmade blasts from earthquakes (Section 3.5) and has a detection threshold of nearly magnitude 0.0 within the ESRP (Section 3.6).

\subsection{Location Method}

The HYPOINVERSE-2000 location program (Klein, 2002) is used to determine locations for all local earthquakes recorded. Phase data files (arrival times of the earthquake) from the output of SEISAN are input into the HYPOINVERSE-2000 program. Stable locations are usually obtained from about seven to ten arrival times (P- and S-waves combined) for recorded events that are not surrounded by INL seismic stations (Zollweg and Sprenke, 1995). Within the INL network, stable locations can be obtained with a minimum of six arrival times. Because of the density and sensitivity of the INL seismic network, the majority of earthquakes located within the $161-\mathrm{km}$ radius have a minimum of six arrival times. However, some earthquakes are located with fewer than six arrival times and, thus, their locations are less accurate. Seismic stations from other agencies monitored by the INL provide coverage outside the INL network and phase arrivals from these stations supplement phase data from INL stations in an attempt to reduce location errors. Other notable parameters used in the HYPOINVERSE-2000 program are the starting focal depth, set to $5 \mathrm{~km}$, and the distance cutoff for arrival weighting, set to $50 \mathrm{~km}$.

Four P-wave velocity models are used in the HYPOINVERSE-2000 program depending on the location of the earthquakes (Table 5). The "ESRP" velocity model is used for locating earthquakes that occur within the ESRP and including the mountainous terrain along the Idaho-Wyoming border and southeast Idaho (Olsen et al., 1979; Sparlin et al., 1979; Braile and Smith, 1979; and Ackerman, 1979). The "INL ESRP" velocity model is used to locate earthquakes that occur on the ESRP and are near or within the INL Site boundaries. This model was developed from Sparlin et al. (1982) and Braile et al. (1982) and checked with respect to a few microearthquakes located within the ESRP (Jackson et al., 1989). The "BPEAK" velocity model is used for locating earthquakes that occur in the Borah Peak aftershock area and the mountainous terrain northwest of the Plain (Richins et al., 1987). Finally, the "SMT" velocity model is used to locate earthquake in southwestern Montana (Stickney, 1997). For all velocity models, a P-wave velocity to S-wave velocity ratio of 1.75 is used (Bones, 1978; Greensfelder and Kovach, 1982; and Richins et al., 1987).

\subsection{Magnitude Methods}

In SEISAN, magnitudes are determined using two methods 1) coda magnitudes using signal duration of digital seismograms, and 2) local magnitudes using amplitudes from digital seismograms. A coda magnitude $\left(\mathrm{M}_{\mathrm{c}}\right)$ is calculated for an earthquake using several signal durations measured from the seismograms of different seismic stations. A local magnitude $\left(\mathrm{M}_{\mathrm{L}}\right)$ is calculated using the largest 
Table 5. P-wave velocity models used in location programs.

\begin{tabular}{|c|c|c|c|c|}
\hline Velocity Model Code & $\begin{array}{l}\text { Velocity } \\
(\mathrm{km} / \mathrm{sec})\end{array}$ & $\begin{array}{l}\text { Depth to Top of } \\
\text { Layer }(\mathrm{km})\end{array}$ & $\begin{array}{c}\text { Layer Thickness } \\
(\mathrm{km})\end{array}$ & References \\
\hline \multirow{4}{*}{ ESRP } & 4.90 & 0.00 & 2.00 & \multirow{4}{*}{$\begin{array}{l}\text { Olsen et al., 1979; } \\
\text { Sparlin et al., 1979; } \\
\text { Braile \& Smith, 1979; } \\
\text { Ackerman, } 1979 .\end{array}$} \\
\hline & 6.00 & 2.00 & 15.00 & \\
\hline & 6.70 & 17.00 & 23.00 & \\
\hline & 7.90 & 40.00 & Half-space & \\
\hline \multirow{7}{*}{ INL ESRP } & 3.30 & 0.00 & 1.00 & \multirow{7}{*}{$\begin{array}{c}\text { Sparlin et al., 1982; } \\
\text { Braile et al., 1982; } \\
\text { Jackson et al., } 1989 .\end{array}$} \\
\hline & 4.90 & 1.00 & 2.00 & \\
\hline & 5.30 & 3.00 & 2.00 & \\
\hline & 6.15 & 5.00 & 2.00 & \\
\hline & 6.53 & 7.00 & 10.00 & \\
\hline & 6.80 & 17.00 & 23.00 & \\
\hline & 8.00 & 40.00 & Half-space & \\
\hline \multirow{5}{*}{ BPEAK } & 4.75 & 0.00 & 1.64 & \multirow[t]{5}{*}{ Richins et al., 1987.} \\
\hline & 5.59 & 1.64 & 5.31 & \\
\hline & 6.16 & 6.95 & 11.05 & \\
\hline & 6.80 & 18.00 & 22.00 & \\
\hline & 8.00 & 40.00 & Half-space & \\
\hline \multirow{4}{*}{ SMT } & 5.52 & 0.00 & 5.86 & \multirow[t]{4}{*}{ Stickney, 1997.} \\
\hline & 6.12 & 5.86 & 12.78 & \\
\hline & 6.74 & 18.64 & 20.05 & \\
\hline & 8.00 & 38.69 & Half-space & \\
\hline
\end{tabular}


peak-to-peak trace amplitude measured from digital waveforms and the Richter magnitude equation. If a magnitude cannot be determined for a local earthquake, then magnitudes determined by other seismic networks may be used including, for example, the University of Utah, Montana Bureau of Mines and Geology, NEIC, Boise State University, and the U.S. Bureau of Reclamation. The summary list of earthquakes in Appendix $\mathrm{C}$ lists the type of magnitude calculated and what institution reported the magnitude.

\subsubsection{Coda Magnitudes}

A coda magnitude is determined by measuring the duration of an earthquake's seismic waves as identified on a vertical component seismogram in SEISAN. In SEISAN when the P-wave arrival time is selected, the earthquake's signal duration can be automatically selected by SEISAN or manually selected by a seismologist at INL. The duration is measured at the start of the earthquake signature (P-wave arrival) to the end of the coda, where the signal fades into the background noise of the trace. The durations are measured for each station where the earthquake's signal can be clearly identified. The following expression from Arabasz et al. (1979) is used to calculate the coda magnitude for each seismic station's duration measured:

$$
\mathrm{M}_{\mathrm{c}}=-3.13+2.74 \log \tau+0.0012 \Delta
$$

Where:

$\tau=$ Total signal duration recorded at the station in seconds;

$\Delta=$ Epicentral distance from the station in $\mathrm{km}$.

The final coda magnitude is determined from the mean of coda magnitudes calculated for each station. The HYPOINVERSE-2000 program uses Equation (1) to estimate the mean coda magnitude along with the location.

\subsubsection{Local Magnitudes}

A local magnitude is determined by measuring the amplitudes of a synthetic Wood-Anderson seismogram digitally for the horizontal components generated in SEISAN. SEISAN allows the seismologist to generate synthetic Wood-Anderson seismograms from shear waves recorded on the horizontal components of accelerometers and seismometers at INL seismic stations. SEISAN calculates synthetic Wood-Anderson seismograms at a magnification of 2800 using the instrument response information for accelerometers and seismometers contained in Appendix C.

For each horizontal component at a station and for multiple stations, the seismologist manually measures or allows SEISAN to automatically measure the largest peak-to-peak amplitude (or A) in millimeters from the synthetic Wood-Anderson seismogram. Once measured, the local magnitude is calculated for each component using the Richter magnitude scale. Richter (1958) defined the local magnitude scale from the following equation:

$$
\mathrm{M}_{\mathrm{L}}=\log \mathrm{A}-\log \mathrm{A}_{\mathrm{o}}
$$

Where:

A = Recorded maximum trace amplitude from the zero-line measured in millimeters on a standard, Wood-Anderson seismogram;

$\mathrm{A}_{\mathrm{o}}=$ Maximum trace amplitude from the zero-line in millimeters for a selected standard earthquake.

The Richter magnitude scale was developed for a standard earthquake of magnitude 3.0 at $100 \mathrm{~km}$ for $\mathrm{A}_{\mathrm{o}}$ $=0.001 \mathrm{~mm}$ and amplitude of $1.0 \mathrm{~mm}$ measured on the standard seismogram. Dr. Richter constructed a table of magnitudes based on distance and $-\log \mathrm{A}_{\mathrm{o}}$ for maximum trace amplitudes recorded on the standard Wood-Anderson seismogram. 
SEISAN has a program that uses equation [2] and measured amplitude of each synthetic WoodAnderson horizontal seismogram to calculate local magnitude. SEISAN uses the distance of the seismic station from the earthquake's epicenter and one-half the peak-to-peak amplitude to determine local magnitude using Richter's table. Typically, the earthquake is located using the HYPOINVERSE-2000 program first to estimate distances from the epicenter to seismic stations, then amplitudes are measured secondly so these distances can be used in the magnitude calculation.

\subsection{Peak Accelerations}

Peak horizontal and vertical accelerations are determined from accelerograms using the SEISAN program. SEISAN displays the horizontal and vertical accelerograms for some free-field SMAs located at the INL and accelerometers co-located with the seismic stations. The SEISAN program allows the user to correct the accelerograms by removing the instrument responses (Section 3.4). A separate program is then used to measure the largest zero-to-peak acceleration amplitude from the corrected acceleration time history.

\subsection{Instrument Response}

Instrument responses of seismic stations and SMAs are regularly determined and maintained for use in SEISAN. The sensitivity and frequency response of the sensor and data logger are used in SEISAN to convert the measured counts of ground motion amplitude to the desired units for acceleration, velocity, and displacement. The instrument responses are held in SEISAN's "GSE" formatted files in the SEISAN database, and INL currently uses GSE 2.0 format. The "GSE2" response files contain the poles and zeros and system gain of the sensor and data logger. Instrument responses are calculated using two approaches depending on whether a seismic station has broadband seismometers, short-period seismometers, or accelerometers, or is an SMA site.

The first approach applies to seismic stations with broadband seismometers. The five new seismic stations (ATRF, ITCF, INLF, MFCF, and NVRF) and the NPRI and CNCI stations with broadband seismometers have response files that are generated using IRIS's Portable Data Collection Center (PDCC) program. PDCC has a library that contains the manufacturer's data for the Nanometrics and Guralp broadband seismometers and the Quanterra Q330 data logger. PDCC is used as a way to store instrument metadata and instrument responses in a file called a "Dataless Seed". The file is in the SEED or Standard for the Exchange of Earthquake Data format, which is a common format used by seismic networks to share earthquake data and store instrument responses. The response files from the Dataless Seed file are converted to SEISAN's GSE2 format for each broadband seismometer component.

The second approach is used for short-period seismic stations with and without accelerometers, SMAs, and accelerometers co-located at broadband stations. Field measurements are made on the data logger at the seismic station or SMA site to quantify the sensitivities. At short-period seismic stations, sensitivities are measured on the DAQSystems NetDAS for each short-period seismometer or each accelerometer component. For the seismometers, GSE2 files are generated using the measured sensitivities along with the filter coefficients of the NetDAS digitizers (Bockholt, 2016) combined with those of the short-period seismometer. For SMAs or seismic stations with accelerometers, GSE2 files are generated using the measured sensitivities and the poles and zeros of the NetDAS digitizers. Finally for accelerometers at broadband seismic stations, sensitivities of each accelerometer component are made on the Quanterra Q330 data logger. These sensitivities and two zeros are used when generating the GSE2 files.

\subsection{Location and Depth Quality}

Comparisons between earthquake locations determined by the INL and locations determined by other temporary networks or NEIC have been used to approximate locations errors of earthquake epicenters (Jackson et al., 1993a). This method is very general and yields an approximation of the quality of the INL 
earthquake locations. Zollweg and Sprenke (1995) evaluated the parameters chosen for the HYPOINVERSE-2000 program used by INL and the locations produced for the INL station geometry. They determined that the parameters chosen yield good location results despite the poor coverage in azimuth of earthquakes outside the network. An evaluation of the difference between actual and computed locations showed that HYPOINVERSE-2000 location error was less than $0.25 \mathrm{~km}$ for test events located by the INL seismic stations. A more detailed discussion of location uncertainty is in Section A-5 (Appendix A).

The HYPOINVERSE-2000 location program also calculates depth to the hypocenter. Focal depths calculated by this program have large uncertainties for many of the earthquakes recorded by the INL seismic network for two reasons: 1) the station spacing is typically greater than twice the focal depth of the earthquake recorded; and 2) earthquakes occur outside of the network resulting in poor station coverage. To calculate accurate focal depths, the earthquake ideally should occur within the seismic network and at a distance equal to or less than it's focal depth, or have S-arrivals from one or more stations within a distance of 1.4 focal depths of the epicenter (Gomberg et al., 1990). Although focal depths are listed in Appendix C, they should be interpreted within the context of the limitations discussed in this section unless otherwise discussed in another section about specific earthquakes.

\subsection{Data Completeness}

Local earthquakes are easily discriminated from other seismic data such as local mine blasts, air blasts (or sonic booms), and distant (worldwide) and regional earthquakes occurring far outside of the INL seismic network. For example, man-made blasts are easily discriminated from earthquakes on the basis of waveform characteristics, the time the event occurred, and the location and depth of the event. The NEIC earthquake website lists are regularly inspected to confirm consistency with the INL earthquake catalog for magnitudes 2.5 and greater. Typically, local mine operators provide lists of blasting times when requested by INL seismologists.

Detection threshold can provide a measure of completeness for the INL earthquake catalog. It is defined as the magnitude level at which the seismic network will nearly always detect and locate an earthquake. Zollweg and Sprenke (1995) evaluated the detection threshold of the INL seismic network by plotting the cumulative number of earthquakes as a function of magnitude to determine the lowest magnitude point that the curve begins to flatten. Zollweg and Sprenke (1995) determined the detection threshold to be a magnitude 1.3 , anywhere within a $161-\mathrm{km}(100-\mathrm{mile})$ radius around INL. Their conclusion was based on a plot of 1360 earthquakes for an 18-month period. Since the seismic stations are all located within $90 \mathrm{~km}$ of the center of INL, they suggested that the detection threshold is magnitude 0.8 within the network on the ESRP. The analysis of Zollweg and Sprenke (1995) suggests that the INL earthquake catalog is complete for magnitudes above 1.3 within a $161-\mathrm{km}$ (100-mile) radius of INL and may be complete for magnitudes as low as 0.8 within the network. Ongoing hardware and software upgrades of INL seismic instrumentation and for the current DAAS have increased detection sensitivities to nearly magnitude 0.0 , which allow recording of small magnitude microearthquakes within ESRP. 


\section{2013 Earthquake Activity}

During 2013, INL recorded 14,011 independent triggers from earthquakes and blasts that occurred in the local region, in the western United States, and worldwide. Of these triggers, 7,355 included blasts and distant, regional, and local earthquakes. Within the local region, INL located 2,085 earthquakes and 150 confirmed and possible man-made blasts. Near and within the 161-km (or 100-mile) radius of INL, 38 earthquakes had small to moderate size magnitudes (M) that ranged from 3.0 to 4.2. Nineteen of the M>3.0 earthquakes were reported felt to the U.S. Geological Survey (USGS). Of the 1,013 earthquakes that occurred within the 161-km radius of INL, three occurred within the ESRP.

\subsection{Regional Earthquakes}

Outside of the 161-km radius of INL, 25 earthquakes from magnitude 3.0 to 3.9 occurred in central Idaho, southern Montana, western Wyoming, and the Idaho-Wyoming border (Figure 5). Twelve of the earthquakes were reported as felt by local residents to the USGS "Did You Feel It" web site (Appendix B).

Five of these earthquakes were located in central Idaho and southern Montana. On July 1, 2013, an $\mathrm{M}_{\mathrm{L}} 3.4$ earthquake occurred and was located northeast of Challis, Idaho, but was not felt (Figure 5). On August 21, 2013, an $\mathrm{M}_{\mathrm{L}} 3.4$ earthquake occurred and was located northeast of Dillon, Montana (Figure 5) and was felt by six residents (Figure B-4b, Appendix B). Three earthquakes of $\mathrm{M}_{\mathrm{c}} 3.3,3.1$, and 3.0 occurred on June 6, November 20, and December 23, 2013, respectively. All three earthquakes were located near the southern end of the Madison fault, which is north of Island Park, Idaho (Figure 5). The $M_{c} 3.1$ and 3.0 earthquakes were each felt by five local residents (Figures B-7a and B-9a, respectively).

From March to November, twelve earthquakes were located in the Yellowstone Plateau in northwestern Wyoming (Figure 5). Seven of the twelve earthquakes occurred in September from the $10^{\text {th }}$ to $24^{\text {th }}$. Earthquake magnitudes ranged from 3.0 to 3.6. The $\mathrm{M}_{\mathrm{L}} 3.3$ earthquake on March 31, 2013 was felt by three local residents (Figure B-1b). The $\mathrm{M}_{\mathrm{L}} 3.4$ and $\mathrm{M}_{\mathrm{L}} 3.6$ earthquakes that occurred on September 15, 2013 were each felt by 15 and 9 local residents, respectively (Figures B-4b and B-5a, respectively).

Nine earthquakes occurred south of Jackson, Wyoming and near the Idaho-Wyoming border. Three earthquakes of $\mathrm{M}_{\mathrm{L}}$ 3.2, 3.6, and 3.9 occurred on December 8, 2013 and were located southeast of Jackson, Wyoming (Figure 5). The $\mathrm{M}_{\mathrm{L}} 3.6$ and 3.9 earthquakes were felt by 8 and 22 local residents, respectively (Figure B-8). To the south, one earthquake with $\mathrm{M}_{\mathrm{L}} 3.1$ occurred on June 20, 2013 and was felt by 15 nearby residents (Figure B-3b). Four earthquakes were located southwest of Afton, Wyoming and along the Idaho-Wyoming border (Figure 5). The largest of the four earthquakes occurred on March 1, 2013, had a moment magnitude $\left(\mathrm{M}_{\mathrm{W}}\right) 3.9$, and was reported felt by 16 nearby residents (Figure B-1a). The next largest earthquake occurring on May 16, 2013 with a $\mathrm{M}_{\mathrm{W}} 3.6$ was felt by 50 local residents (Figure B-3a). The greater number of reports for the $\mathrm{M}_{\mathrm{W}} 3.6$ is likely due to the closer proximity of earthquake to Afton, Wyoming whereas the $\mathrm{M}_{\mathrm{W}} 3.9$ earthquake was further to the south of Afton. Earthquakes of $\mathrm{M}_{\mathrm{L}} 3.0$ and 3.1 occurred on November 29, 2013 and were located between the $\mathrm{M}_{\mathrm{W}} 3.6$ and 3.9 events (Figure 5). Only the $\mathrm{M}_{\mathrm{L}} 3.1$ earthquake was felt by three local residents (Figure B-7b). Finally, one earthquake with $\mathrm{M}_{\mathrm{L}} 3.1$ occurred on July 28, 2013 and was located south of Soda Springs, Idaho (Figure 5), but was not felt by residents nearby.

\subsection{Earthquakes within 161-km Radius of INL}

During 2013, 1,013 earthquakes occurred within 161-km radius of INL and thirteen of these events had magnitudes from 3.0 to 4.2 (Appendix C). Seven earthquakes were felt by local residents. The earthquakes included three swarms and a mainshock-aftershock sequence. The earthquakes within 161$\mathrm{km}$ radius were located northwest of the INL in the Basin and Range regions of Idaho and Montana and southeast of the ESRP in the Basin and Range region along the Idaho-Wyoming border (Figure 6). 
Scattered earthquakes occurred along the Lost River, Lemhi, and Beaverhead faults and a swarm of earthquakes occurred in the Beaverhead Mountains near the Idaho-Montana border (Figure 6). On July 18,2013 , an earthquake of $\mathrm{M}_{\mathrm{c}} 3.3$ was located east of Stanley, Idaho within the 161-km radius of INL, but was not felt. In May, a swarm of 62 earthquakes occurred in the Beaverhead Mountains near the Idaho-Montana border (Figure 6). The swarm included five earthquakes with magnitudes of $\mathrm{M}_{\mathrm{c}} 3.0$ (two), $\mathrm{M}_{\mathrm{c}}$ 3.2, $\mathrm{M}_{\mathrm{c}} 3.3$, and $\mathrm{M}_{\mathrm{c}} 3.4$ (Figure 5) that occurred May $21^{\text {st }}$ to $23^{\text {rd }}$ during the time period with the greatest number of earthquakes. None of the magnitude 3.0 or greater earthquakes was felt by nearby residents. The swarm continued with infrequent events until December. Further east of this swarm near the southern end of the Madison fault and within the 161-km radius of INL (Figure 6), a $\mathrm{M}_{\mathrm{c}} 3.0$ earthquake occurred on August 28, 2013. This earthquake was located west of the three earthquakes that were located near the southern end of the Madison fault and was not felt by residents nearby (Figure 5).

Two earthquake swarms and a mainshock-aftershock sequence occurred southeast of the ESRP along the Idaho-Wyoming border. A swarm of $>180$ earthquakes occurred at Driggs, Idaho. The swarm began with some earthquakes occurring in January and June but intensified with more than 160 events in November and December. Two of the larger earthquakes were felt by local residents in Driggs, which occurred on December 29, 2013 and December 30, 2013 and had magnitudes of $\mathrm{M}_{\mathrm{L}} 2.8$ and 3.1, respectively (Figures B-9b and B-10, respectively). A less intense swarm of earthquakes occurred in July and ended in October and was located west of Jackson, Wyoming along the border with Idaho (Figure 6). The largest event in the swarm was a $\mathrm{M}_{\mathrm{W}} 3.8$ that occurred on October 19, 2013 within the 161-km radius of INL (Figure 5) and was felt by 16 local residents (Figure B-5b). The swarm included 64 events with $>20$ occurring on October 19, 2013.

To the south of the July-October swarm, two earthquakes of $\mathrm{M}_{\mathrm{L}} 3.3$ and 3.9 occurred on October 19, 2013 and November 17, 2013, respectively (Figure 5). The October and November events were each felt by nine local residents (Figure B-6). Finally, southeast of Pocatello, Idaho on May 6, 2013 an earthquake of $\mathrm{M}_{\mathrm{L}} 4.2$ was followed by 18 aftershocks that included a $\mathrm{M}_{\mathrm{L}} 3.6$ (Figure 5). The $\mathrm{M}_{\mathrm{L}} 4.2$ earthquake was felt by 139 residents due to its proximity to many nearby towns (Figure B-2a). The $\mathrm{M}_{\mathrm{L}} 3.6$ event was reported felt by only 13 residents likely because it occurred 7 minutes after the $M_{L} 4.2$ and many residents likely did not distinguish between the two events (Figure B-2b).

Three earthquakes occurred within the ESRP and three other earthquakes were located at the northwest edge of the ESRP (Figure 6). On January 31, 2013 a $\mathrm{M}_{\mathrm{c}} 1.3$ earthquake was located in the center of ESRP north of the Great Rift and at a depth of $45 \mathrm{~km}$. To the west, an earthquake of $\mathrm{M}_{\mathrm{c}} 0.7$ occurred on February 19, 2013 and was located at a depth of $37 \mathrm{~km}$ and at the northwestern end of the Great Rift at its juncture with the mountains. Four earthquakes, $\mathrm{M}_{\mathrm{c}} 0.0, \mathrm{M}_{\mathrm{c}} 1.3, \mathrm{M}_{\mathrm{c}} 1.8$, and $\mathrm{M}_{\mathrm{c}} 1.1$, occurred on May 1, May 9, July 1, and September 9, 2013, respectively, and were located north of the INL along the edge of the ESRP. The $\mathrm{M}_{\mathrm{c}} 0.0$ and 1.1 earthquakes were located just within the ESRP.

\section{Earthquakes from 1972 to 2013}

The earthquakes in 2013 were located in areas around and within the ESRP that have been active in previous years. Figure 7 shows that the majority of 2013 earthquakes occur in the Basin and Range Province regions surrounding the ESRP. Even though 87 microearthquakes $(M \leq 2.2)$ have occurred within the ESRP, monitoring by the INL seismic network indicates that at present the ESRP is relatively seismically inactive when compared to surrounding Basin and Range Province (see also Jackson et al., 1993b). Ongoing activity of 30 events (2007-2013) within and near the Great Rift suggests possible association with volcanic processes. Nearly 2,200 years ago, volcanic activity occurred along the entire 80-km length of the Great Rift (Kuntz et al., 2002). 


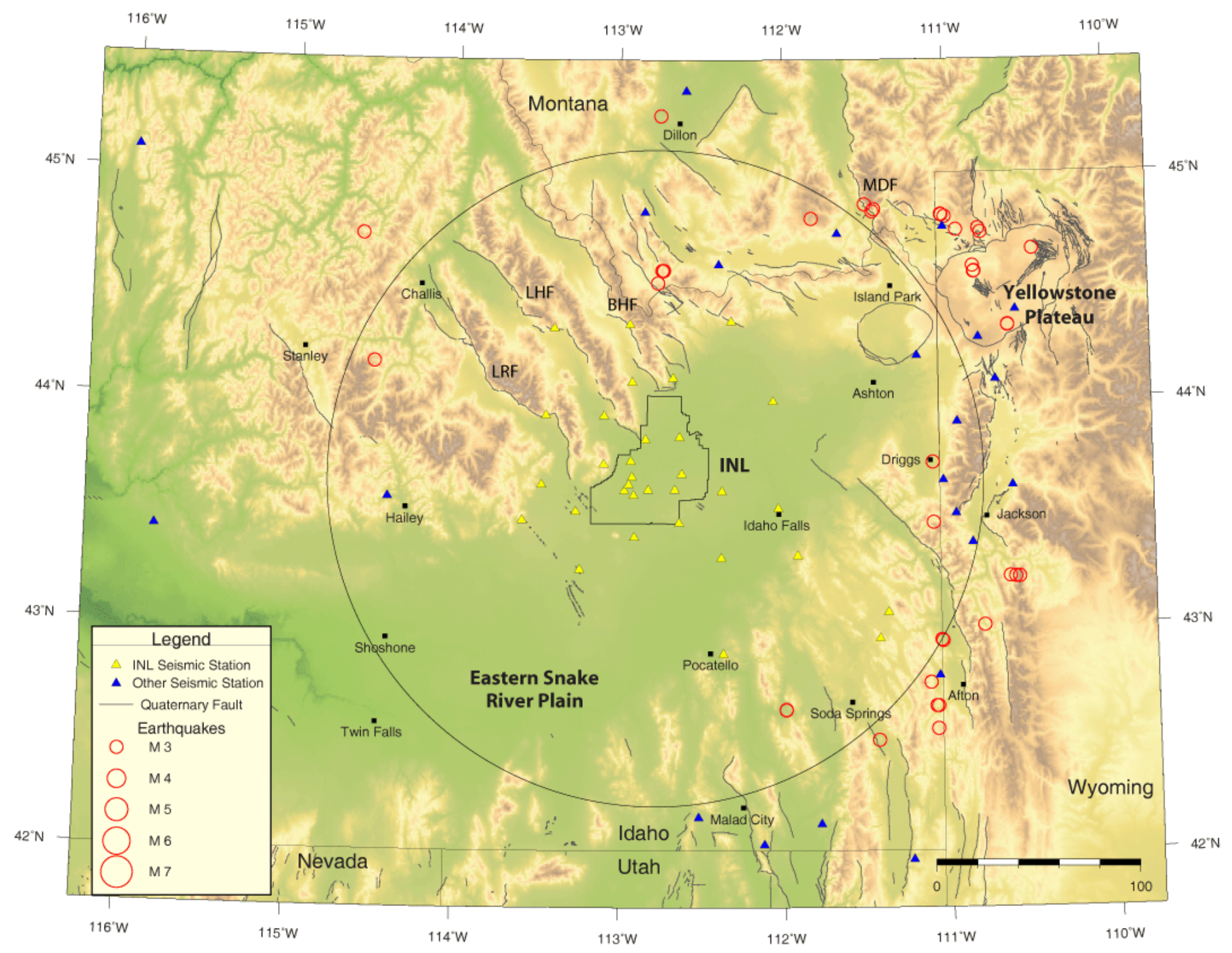

Figure 5. Map of earthquakes with magnitudes greater than 3.0 occurring during 2013. Normal fault abbreviations include: BHF - Beaverhead; LHF - Lemhi; LRF - Lost River; and MDF - Madison. 


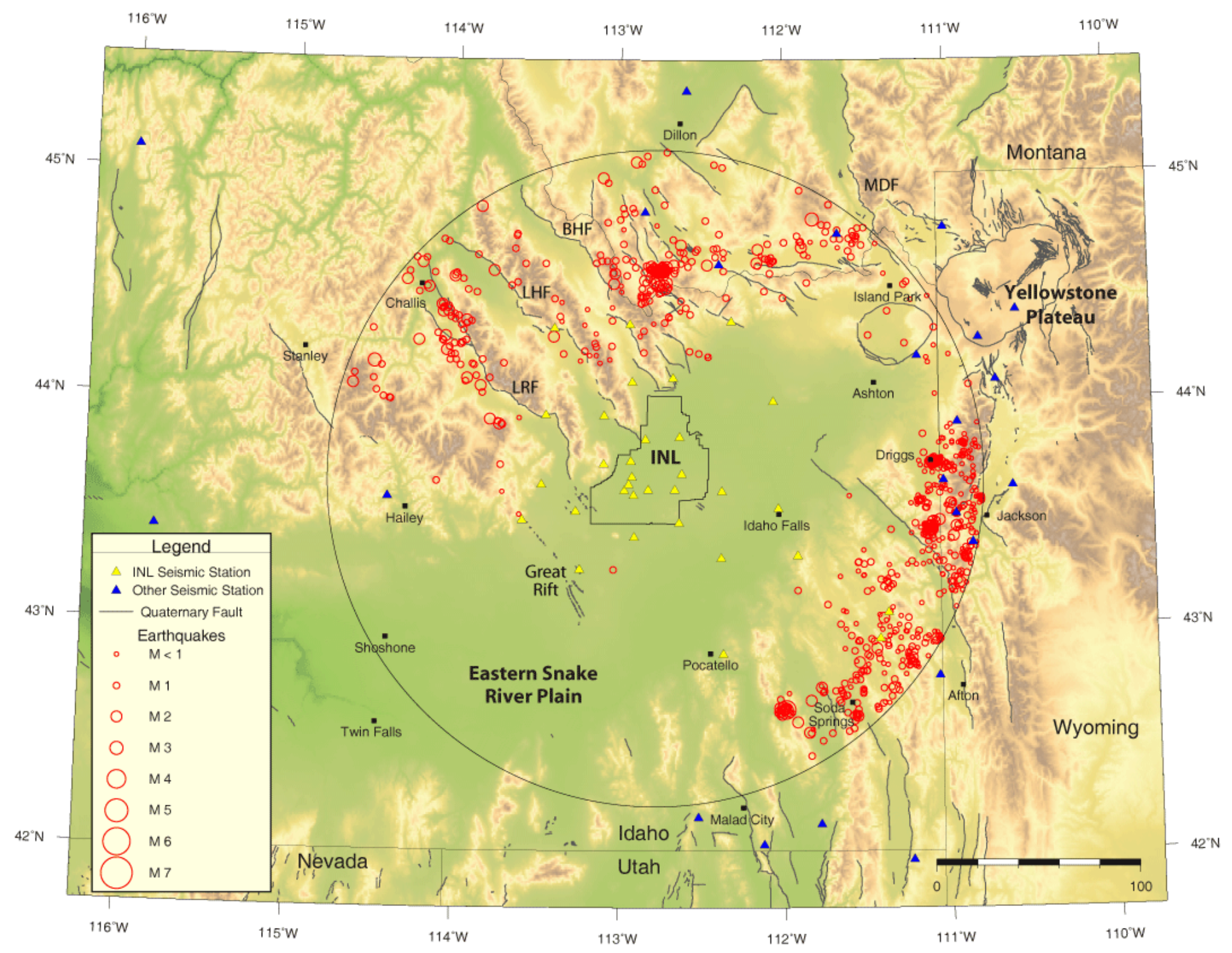

Figure 6. Map of epicenters of earthquakes within the 161-km radius around the INL from January 1, 2013 to December 31, 2013. Normal fault abbreviations include: BHF - Beaverhead; LHF - Lemhi; LRF - Lost River; and MDF - Madison. 


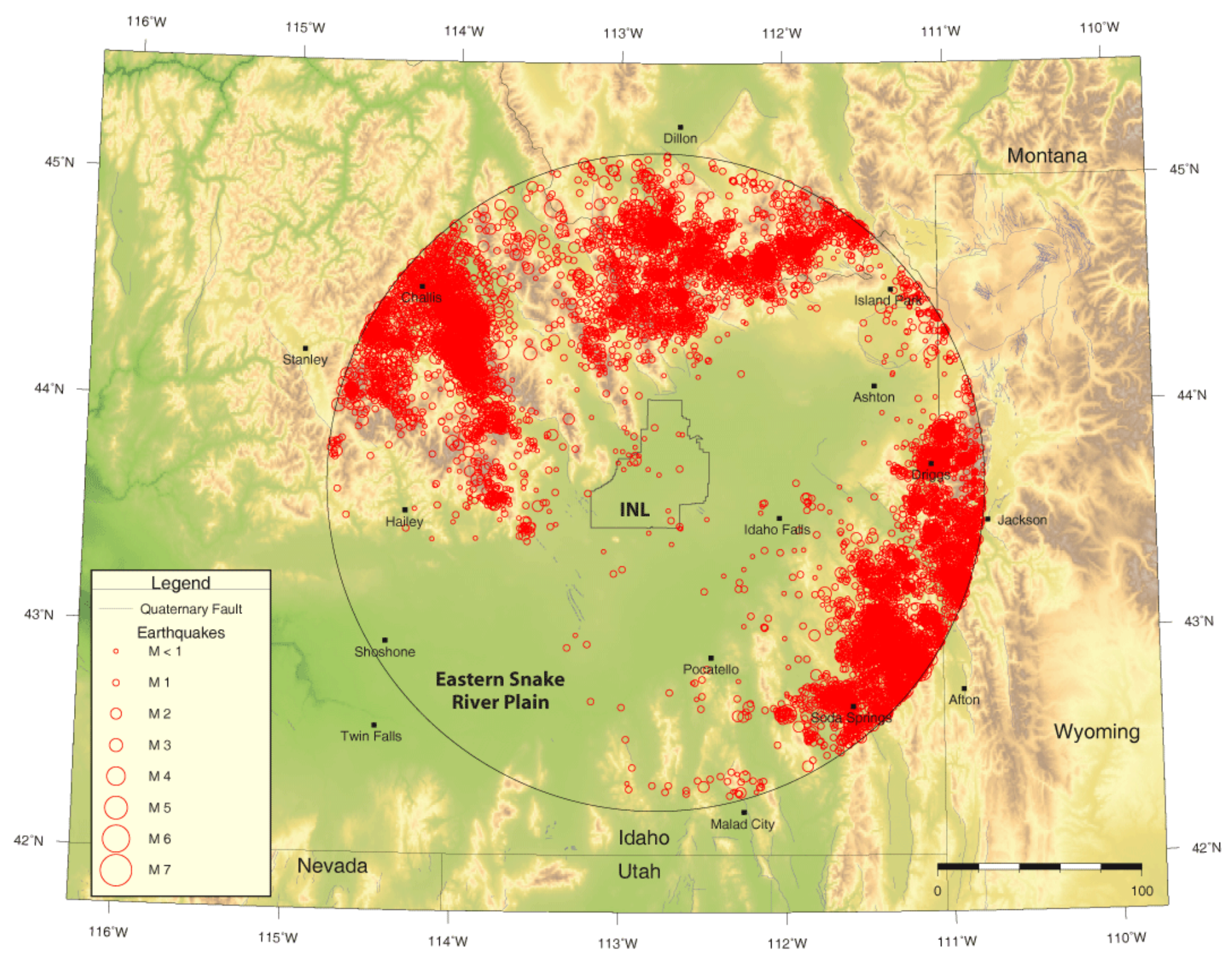

Figure 7. Map of epicenters of earthquakes from 1972 to 2013 within the 161-km (100 mile) radius around the INL. 


\section{References}

Ackerman, H. D. (1979). Velocity Structure to 3000-Meter Depth at the Idaho National Engineering Laboratory, Eastern Snake River Plain (abstract), EOS Transactions, American Geophysical Union, v. 60, no. 46 , p. 942.

Arabasz, W. J., R. B. Smith, and W. D. Richins (1979). Earthquake Studies Along the Wasatch Front, Utah: Network Monitoring, Seismicity, and Seismic Hazards, Earthquake Studies in Utah - 1850 to 1978, W. J. Arabasz, R. B. Smith, and W. D. Richins, Editors, published by the University of Utah, p. 253-286.

Bockholt, B.M. (2016). Performance tests of data loggers at the Idaho National Laboratory, Seismological Research Letters, v. 87, no.6, doi:10.1785/0220160092.

Bones, D. B. (1978). Seismicity of the Intermountain Seismic Belt in Southeastern Idaho and Western Wyoming, and Tectonic Implications, unpublished M. S. Thesis, University of Utah.

Braile, L. W. and R. B. Smith (1979). The Structure of the Crust in the Yellowstone-Snake River Plain Area and Adjacent Provinces and Implications for Crustal Evolution (abstract), EOS Transactions, American Geophysical Union, v. 60, no. 46, p. 941.

Braile, L. W., R. B. Smith, J. Ansorge, M. R. Baker, M. A. Sparlin, C. Prodehl, M. M. Schilly, J. H. Healy, ST. Mueller, and K. H. Olsen (1982). The Yellowstone-Snake River Plain Seismic Profiling Experiment: Crustal Structure of the Eastern Snake River Plain, Journal of Geophysical Research, v. 87, no. B4, p. 2597-2609.

DOE (2012). Facility Safety, U.S. Department of Energy, DOE Order 420.1C.

Gomberg, J. S., K. M. Shedlock, and S. W. Roecker (1990). The effect of S-wave arrival times on the accuracy of hypocenter estimation, Bulletin of the Seismological Society of America, v. 80, p. 16051628.

Greensfelder, R. W. and R. L. Kovach (1982). Shear Wave Velocities and Crustal Structure of the Eastern Snake River Plain, Idaho, Journal of Geophysical Research, v. 87, no. B4, p. 2643-2653.

Jackson, S. M., D. M. Anderson, G. S. Carpenter, H. K. Gilbert, S. M. Martin, and P. J. Permann (1989). The 1988 INEL Microearthquake Survey near the Western Edge of the eastern Snake River Plain, EG\&G Internal Technical Report EGG-BEG-8665, August, 48 p.

Jackson, S. M., G. S. Carpenter, D. M. Anderson, D. L. Scott, J. L. Casper, and R. B. Powell (1993a). INEL Seismograph Stations Annual Report: January 1 - December 31, 1992, EG\&G Internal Technical Report EGG-EELS-004, 114 p.

Jackson, S. M., I. G. Wong, G. S. Carpenter, D. M. Anderson, and S. M. Martin (1993b). Contemporary Seismicity in the eastern Snake River Plain, Idaho based on Microearthquake Monitoring, Bulletin of the Seismological Society of America, v. 83, no. 3, June, p. 680-695.

Klein, F.W. (2002). User's guide to HYPOINVERSE-2000, a Fortran program to solve for earthquake locations and magnitudes, U.S. Geological Survey Open-File Report, 02-171.

Kuntz, M.A., Anderson, S.R., Champion, D.E., Lanphere, M.A. \& Grunwald, D.J. (2002). Tension cracks, eruptive fissures, dike, and faults related to late Pleistocene - Holocene basaltic volcanism and implications for the distribution of hydraulic conductivity in the eastern Snake River Plain, Idaho, in Link, P.K. and L.L. Mink, eds., Geology, Hydrogeology, and Environmental Remediation: Idaho National Engineering and Environmental Laboratory, Eastern Snake River Plain, Idaho, Geologic Society of America Special Paper, 353, p. 111-133. 
Olsen, K. H., E. F. Homuth, J. N. Stewart, R. N. Felch, T. G. Handel, and P. A. Johnson (1979). Upper Crustal Structure Beneath the Eastern Snake River Plain Interpreted from Seismic refraction Measurements Near Big Southern Butte, Idaho (abstract), EOS Transactions American Geophysical Union, v. 60, no. 46, p. 941.

Payne, S.J., B.D. Coryell, and J.M. Hubbell (2012a). Evaluations of existing subsurface data and recommendations for new data collection in support of INL probabilistic seismic hazard analyses, Battelle Energy Alliance, INL-LTD-12-26965, September.

Payne, S. J., R. McCaffrey, and S. A. Kattenhorn (2013). Extension Driven Right-lateral Shear in the Centennial Shear Zone Adjacent to the Eastern Snake River Plain, Idaho, Lithosphere, v. 5, no.4, p. 407-419.

Payne, S.J., R. McCaffrey, R.W. King, and S.A. Kattenhorn (2012b). An new interpretation of deformation rates in the Snake River Plain and adjacent Basin and Range regions from GPS measurements, Geophysics Journal International, v. 189, p. 101-122, doi: 10.1111/j.1365246X.2012.05370.x.

Richins, W. D., J. C. Pechmann, R. B. Smith, C. J. Langer, S. K. Goter, J. E. Zollweg, and J. J. King (1987). The 1983 Borah Peak, Idaho Earthquake and Its Aftershocks, Bulletin of the Seismological Society of America, v. 77, no. 3, p. 694-723.

Richter, C. F. (1958). Elementary Seismology, W. H. Freenam and Company, San Francisco, p. 340-342.

Sparlin M., L. W. Braile, M. R. Baker, and R. B. Smith (1979). Interpretation of Seismic Profiles Across the Eastern Snake River Plain (abstract), EOS Transactions American Geophysical Union, v. 60, no. 46, p. 941.

Sparlin, M. A., L. W. Braile and R. B. Smith (1982). Crustal Structure of the Eastern Snake River Plain Determined from Ray Trace Modeling of Seismic Refraction Data, Journal of Geophysical Research, v. 87 , no. B4, p. 2619-2633.

Stickney, M.C. (1997). Seismic source zones in southwest Montana, Montana Bureau of Mines and Geology, Butte, Montana Open-file report 366.

U.S. Geological Survey (2016). "Did You Feel It?” web archives http://earthquake.usgs.gov/earthquakes/dyfi/archives.php, accessed December.

Zollweg, J.E., and K. F. Sprenke (1995). Review of Idaho National Engineering Laboratory Seismographic Networks and Seismic Hazard Program, prepared for the State of Idaho INEL Oversight Program, Technical Report 95-01, 72 p. 


\section{Appendix A}

\section{Seismic Network Information}

\section{A-1. INL Seismic Network History}

The INL seismic network has evolved from a single analog station to its current configuration of 32 digital seismic stations. The INL Seismic Monitoring Program also records data from seismic stations owned and operated by other seismic networks. The INL seismic network began with a single station in 1971 and expanded to three stations by October of 1972. In 1977, the INL began monitoring a station operated by BYU-Idaho in Rexburg, Idaho. The INL installed two additional stations in 1979 and from 1979 to 1985, the INL monitored earthquake activity using six seismic stations. In 1985, the INL installed a simulated Wood-Anderson system to improve the capabilities of measuring magnitudes of local earthquakes $(3.0<M<5.0)$. During 1986, the INL began receiving seismic data from a station located in Pocatello, Idaho and operated by the University of Utah in Salt Lake City, Utah. Also in 1986, the INL began receiving data from a station located near Palisades Reservoir, Idaho that is operated by BYUIdaho. A seismic station within the INL boundaries was added to the INL seismic network in 1987.

From 1990 to 1994, INL seismic network underwent a major expansion of seismic stations. During 1990, four seismic stations were installed within the INL boundaries. From 1991 to 1992, thirteen new stations were installed in support of construction and operation of the proposed New Production Reactor at INL. Shallow boreholes $(<18 \mathrm{~m})$ were drilled for seismic stations located within the ESRP. Also, monitoring of BYU-Idaho seismic station near Palisades Reservoir was terminated in 1991 to accommodate the addition of the new INL seismic stations. In 1994, two new INL seismic stations were installed near Gray's Lake, Idaho.

Several changes occurred to seismic stations from 1999 to 2003. During 1999, the INL Howe Scarp, Idaho (HWSI) seismic station was relocated further east to a new location now referred to as the Howe Fault, Idaho or HWFI because of a lawsuit filed against the Bureau of Land Management. With the implementation of the "EARTHWORM" computer software in 2000, up to 14 stations from several nearby networks were being recorded in real-time along with the INL seismic stations. During 2001-2003, analog seismic instruments at all INL seismic stations were replaced with digital instruments. In 2003, the University of Utah transferred ownership of the Pocatello, Idaho (PTI) seismic station to the INL Seismic Monitoring Program at which time a digital seismic station was installed. With addition of the PTI station, INL has operated 27 seismic stations from 2003 through 2012.

In 2013, five new seismic stations were installed on INL near facility areas. The stations included: Advanced Test Reactor, Idaho (ATRF), Idaho Nuclear Technology and Engineering Center, Idaho (ITCF), INEL-1 Drill Site, Idaho (INLF), Materials and Fuels Complex, Idaho (MFCF), and Naval Reactors Facility, Idaho (NVRF). The stations were installed with broadband seismometers to record regional earthquakes with magnitudes from 3 to 5 that can be used in future INL seismic hazard analyses to characterize ground motion models. With the addition of these five stations, the INL operated 32 seismic stations.

\section{A-2. INL Strong Motion Accelerograph History}

The INL has a network of SMA and three-component accelerometer sites that has undergone changes in site locations. Prior to 1978, the original network had eleven SMAs that included three SMAs installed within buildings at the Idaho Nuclear Technology and Engineering Center (INTEC) (formerly referred to 
as Idaho Chemical Processing Plant - ICPP), two located within the Materials and Fuels Complex (MFC) facilities (formerly referred to as Argonne National Laboratory - ANL), three installed within the Power Burst Facility (PBF), two located within buildings at the Advanced Test Reactor (ATR) (formerly referred to as Test Reactor Area - TRA), and one located at the Old Fire Station (OFS). From 1978 to 1979, four SMAs were installed at Test Area North (TAN) within the Containment Test facility (formerly referred to as Loss of Fluid Test - LOFT facility). Just prior to the October 1983 surface-wave magnitude $\left(\mathrm{M}_{\mathrm{s}}\right) 7.3$ Borah Peak, Idaho earthquake, one SMA was installed at the IRC, which is now part of the REC in Idaho Falls, Idaho. Following the 1983 earthquake, two SMAs were installed within buildings at the Naval Reactor Facility (NRF). In 1984, two additional SMAs were placed within buildings at INTEC. During 1990, one SMA was installed at the Central Facilities Area (CFA). A digital SMA was co-located with an analog SMA at MFC in 1993. In 1996, two free-field SMA sites were installed, one at NRF and the other at PBF. In 1997, one SMA was installed as a free-field site at the Radioactive Waste Management Complex (RWMC). In 2003, the SMAs were upgraded to digital NetDAS SMAs. At that time, one NetDAS digital SMA replaced two SMAs co-located at Building ANL-767 (Kinemetrics analog SMA-1 and digital SSA-2 accelerographs). The SMA on the crane beam at PBF-620 was not upgraded, but removed due to decommissioning activities.

Over the years, several SMAs have been relocated because buildings have been decommissioned and demolished. In 1995, the SMA at OFS was moved to a storage building directly behind the fire station because the fire station was decommissioned. In 1997, when the storage building was demolished, this SMA was relocated to the Experimental Field Station (EFS). In 1996, the Containment Test facilities, or LOFT facilities, were decommissioned. Three of the SMAs from LOFT were moved to the TAN Hot Shop and one was placed at the TAN Air Monitoring building. In 1997, the SMA at CFA was relocated to CFA-1607 Refueling Building. In 2004, the TAN Air Monitoring building was demolished so the SMA was removed and was reinstalled in 2005 as a free-field near the TAN Hot Shop. In 2004, the PBF building was demolished and the three SMAs were removed. The SMAs were reinstalled in 2005 as freefield sites near PBF and RWMC. In 2006, four SMAs at TAN were removed due to demolition of the TAN Hot Shop. In 2007, two of these SMAs were reinstalled; one was installed at the Special Manufacturing Complex (SMC) and the other at a free-field site east of SMC. In 2008, two SMAs were removed as a result of building demolition activities. One SMA at INTEC in building CPP-668 and one at ATR were removed. These SMAs were reinstalled at TAN and the New Production Reactor seismic station, NPRI. During 2009, two SMAs were removed at INTEC from building CPP-601 as a result of building demolition activities. In 2010, the SMA at CFA, called EFSF, was uninstalled, moved to the nearby pump house, and renamed to PHFF.

Three-component accelerometers and SMAs were added to some of the seismic stations. In 2002, accelerometers were added to four seismic stations: Bear Canyon (BCYI), Gray's Range (GRRI), NPRI, and HWFI. In 2003, accelerometers were added to seismic stations Telchick Spring, Idaho (TCSI), Split Crater (SPCI), and PTI. In 2004, the accelerometer at TCSI was uninstalled. In 2008, a free-field SMA was installed at the Craters of the Moon (COMF) seismic station. In 2013, five new free-field sites were installed near INL facility areas, including ATR, INTEC, NRF, and MFC, and at the 3-km deep INEL-1 drill hole. Three-component accelerometers were co-located with broadband seismometers at sites, ATRF, ITCF, INLF, MFCF, and NVRF. The five stations were added to record earthquakes that can be used to assess parameters of ground motion models for future seismic hazard analyses. During 2013, the INL operated a total of 30 sites with acceleration recording capabilities. 


\section{A-3. INL Seismic Network Telemetry}

Digital radios, Internet, or DSL links transmit seismic data from INL seismic stations and free-field SMAs to the IRC. Some seismic stations are used as relay links to transmit several seismic stations to a DSL drop point or directly to the IRC. Figure A-1 shows the telemetry configuration during 2013.

\section{A-4. Evolution of INL Seismic Data Acquisition and Analysis Computer System}

INL began recording earthquake data on the DAAS June 8, 1991 using the USGS's CUSP processing software. Since 2001, significant upgrades have been made to the DAAS as a result of computer hardware and software advances. The USGS's CUSP data acquisition and analysis software supported use of the TIMIT program, which was used to analyze earthquake data from June 1991 to November 2002. The USGS CUSP and TIMT software packages were replaced in 2002 with the earthquake analysis

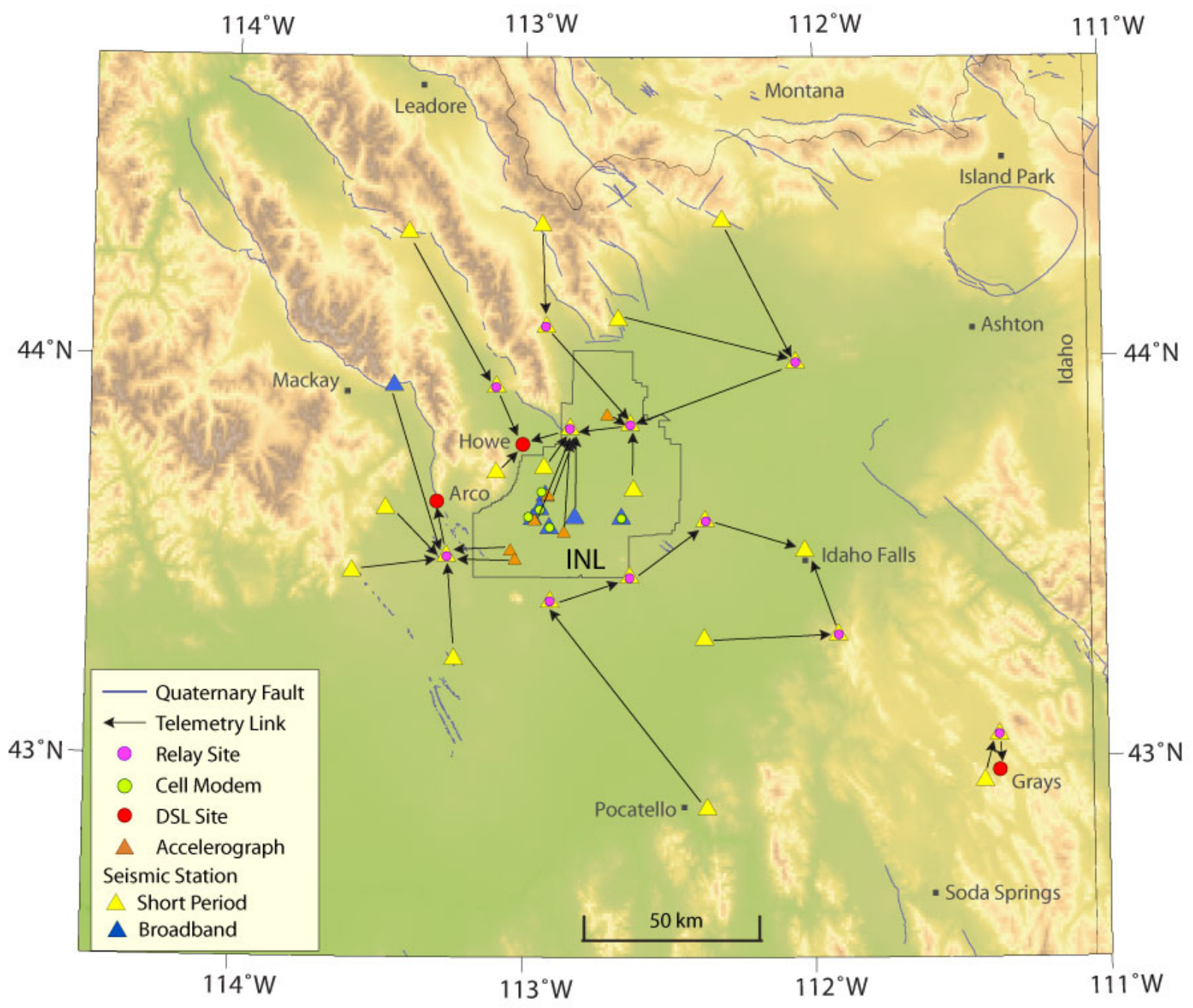

Figure A-1. Telemetry configuration of INL seismic stations and free-field SMAs during 2013. 
program SEISAN (developed by the University of Bergen, Norway) and the USGS's EARTHWORM processing software in 2003. As of December 2002, earthquake data are analyzed using the SEISAN program and is still in use today. Use of the SEISAN and EARTHWORM programs facilitate the upgrades of seismic stations and SMAs to currently available digital data loggers and sensors, which enables concurrent waveform analyses of both velocity and acceleration data.

\section{A-5. 1995 Evaluation of INL Seismic Network Location Quality}

In 1995, the State of Idaho at that time requested that Zollweg and Sprenke (1995) perform an independent assessment of the INL Seismic Monitoring Program. Zollweg and Sprenke (1995) evaluated the location accuracy of the INL seismic network by two methods: 1) directly comparing INL locations to well-located earthquakes; and 2) indirectly by evaluating the network bias or non-random error through varying independent permutations (or combinations) of recording stations.

For the first method, twenty-two earthquakes having high-quality locations determined from a temporary seismic network installed near Challis, Idaho from July 1, 1992 to July 12, 1992 (by Boise State University) were compared to INL locations for these earthquakes. The earthquakes were located about $120 \mathrm{~km}$ from the center of INL, had varying magnitudes ranging from 1.9 to 4.5 , and had absolute errors less than $1 \mathrm{~km}$. The epicenters determined by INL seismic stations for these events differed by 1.6 to $11.5 \mathrm{~km}$ with an average of $7.1 \mathrm{~km}$. The differences in locations were dependent on magnitude, with the smaller magnitude earthquakes tending to have greater differences in locations (Zollweg and Sprenke, 1995). These results are similar to the earlier estimates of an error radius of $5 \mathrm{~km}$ for a comparison to high-quality locations of the aftershocks from the $\mathrm{M}_{\mathrm{s}} 7.3$ October 28, 1983 earthquake (Jackson et al., 1993a). However it is noted that this estimate for an error radius was based on having five stations in the INL seismic network at that time. The closest station to the aftershocks was at a distance of $50 \mathrm{~km}$ or more.

The second method used by Zollweg and Sprenke (1995) evaluates the network bias. Unless all earthquakes are located using exactly the same groups of stations and phases (P- and S-wave arrivals), the relative locations will be affected by a non-random error or network bias. The network bias is important for the smaller earthquakes that make up the majority of the events in a catalog since fewer stations usually record smaller earthquakes. Five earthquakes located northwest of the INL seismic network and ranging in magnitude from 1.8 to 3.8 were used in the analysis. Because INL operated 26 seismic stations at the time of the assessment, there were millions of possible combinations of recording stations. Zollweg and Sprenke (1995) chose to vary the combination of the ten most influential phase arrivals for the permutation analysis. The locations for most of the permutations clustered about radii ranging from 6.5 to $11 \mathrm{~km}$. For the magnitude 3.8 earthquake, $8 \%$ of the permutations resulted in a linear band extending 100 $\mathrm{km}$. Zollweg and Sprenke (1995) suggested that earthquakes located with fewer S-wave arrival times have less well-constrained locations. Some of the larger earthquakes, like the magnitude 3.8 earthquake, have fewer S-wave arrival times because the signals saturate the instrumentation and onset of the S- wave is indistinguishable from the P-waves. Earthquakes with more than three S-wave-arrival times resulted in better-constrained locations. 


\section{Appendix B}

\section{Earthquake Intensity Maps}

The USGS with the cooperation of various regional seismic networks provide a web page where people who experience an earthquake can go online and share information about its effects to help create a map of shaking intensities and damage. The "Community Internet Intensity Maps" contribute toward the quick assessment of the scope of an earthquake emergency and provide valuable data for earthquake research (U.S. Geological Survey, 2016). The website is called "Did You Feel It?" and is the place where a person can enter their ZIP Code and answer a list of questions about what they felt and what damage occurred.

Maps in Figures B-1 to B-10 show the responses from local residents for 19 earthquakes that were felt during 2013 (see Section 4). The earthquakes are identified in the figure caption by the date that corresponds to the time (hour and minute) in UTC. The maps were downloaded from the USGS "Did You Feel It?" website and thus are labeled at the top with the date that corresponds to the local time when the earthquake occurred (U.S. Geological Survey, 2016). The earthquakes are shown in chronological order. 
a)

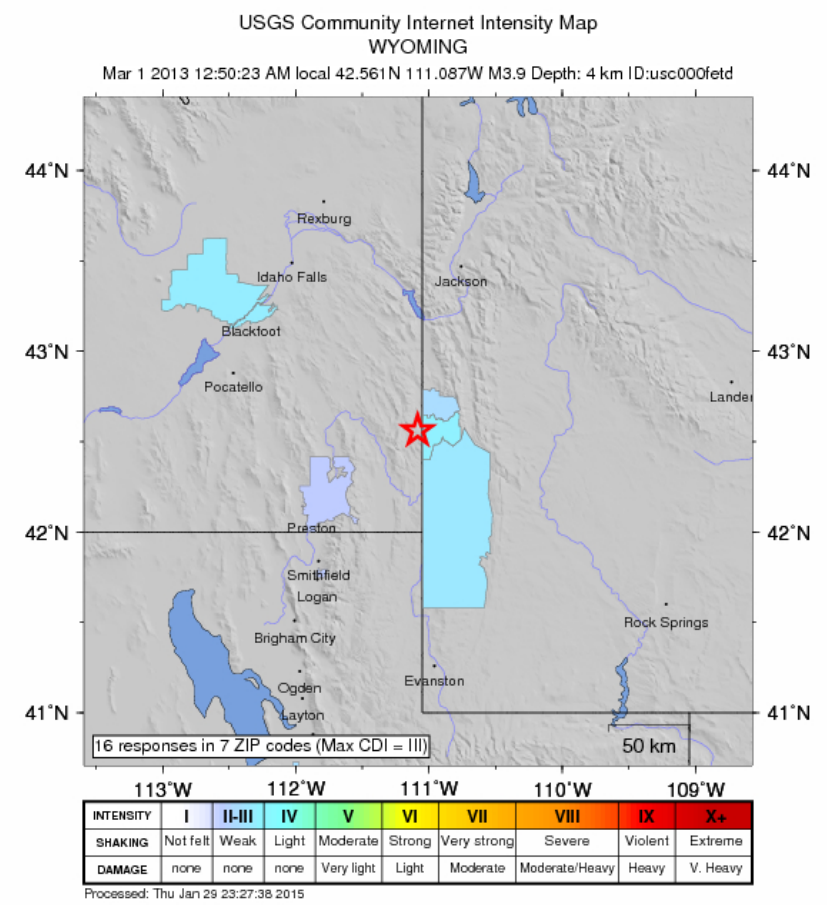

b)

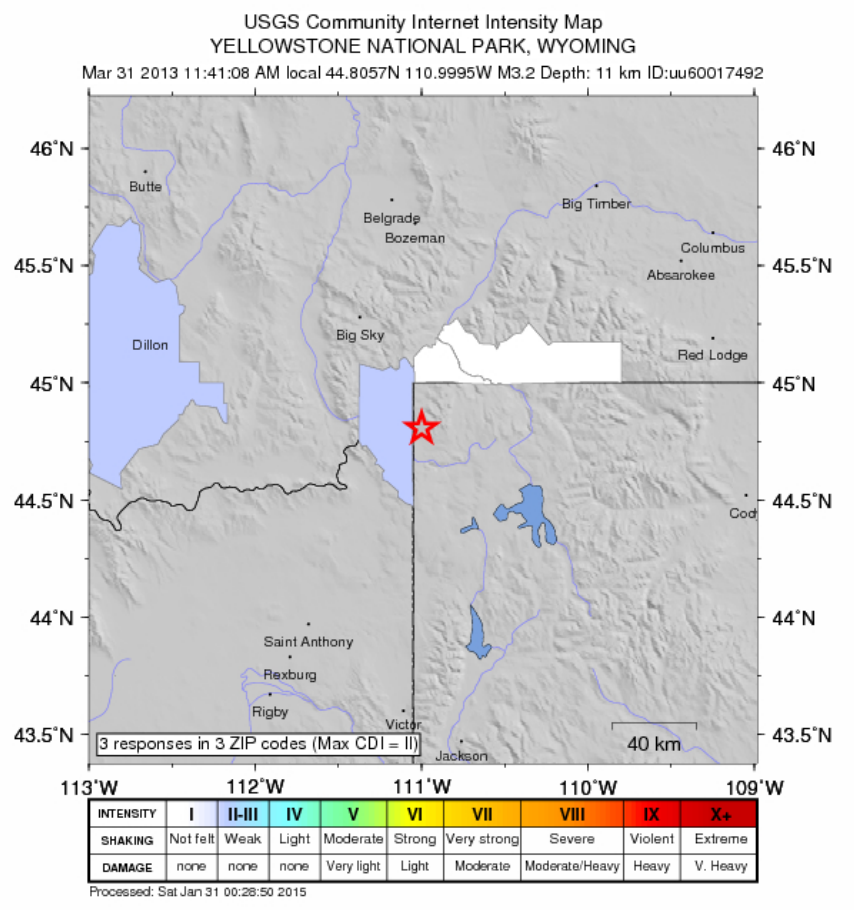

Figure B-1. Intensity maps for: a) March 1, 2013 (07:50 UTC) $\mathrm{M}_{\mathrm{W}} 3.9$ earthquake; and b) March 31, 2013 (17:41 UTC) $M_{L} 3.2$ earthquake (U.S. Geological Survey, 2016). 
a)

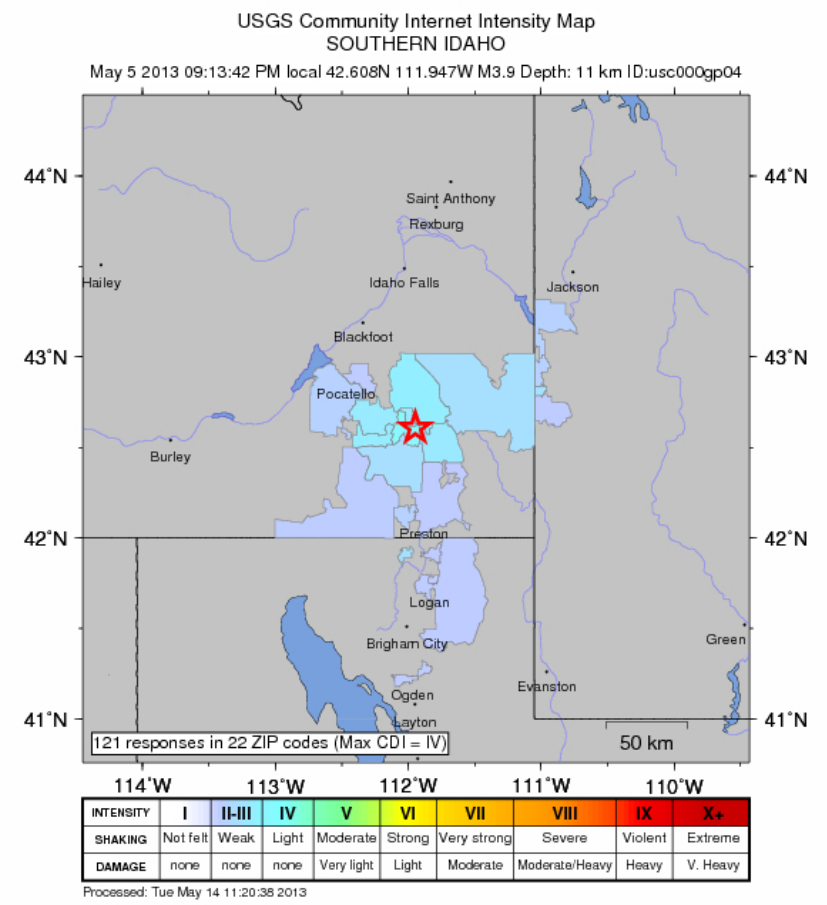

b)

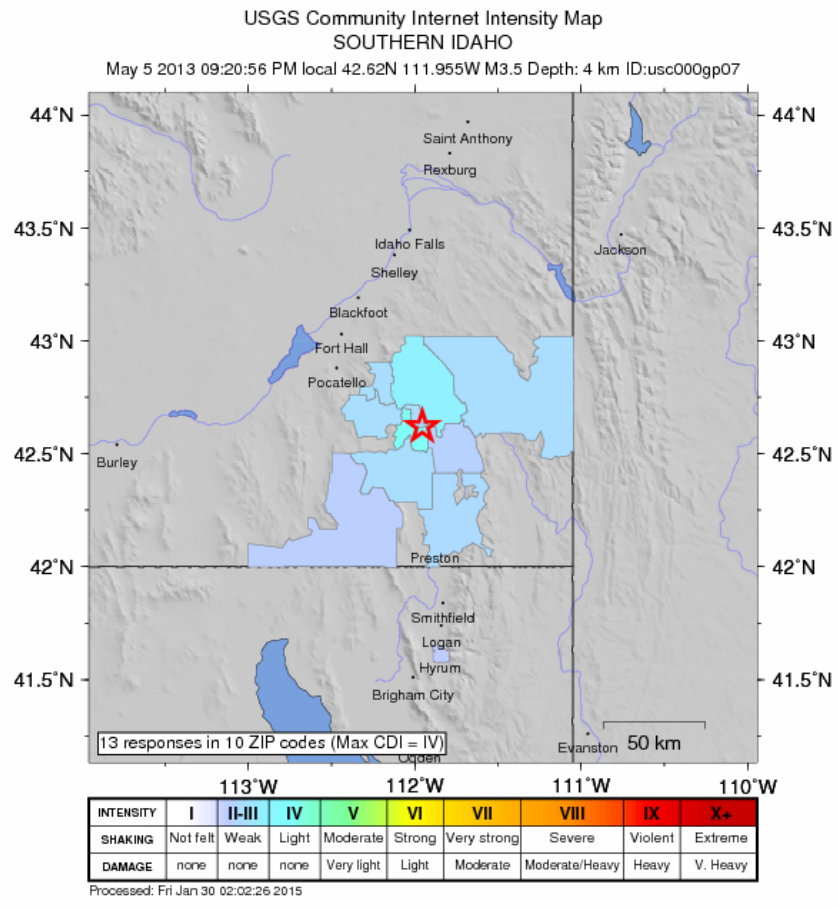

Figure B-2. Intensity maps for: a) May 6, 2013 (03:13 UTC) $\mathrm{M}_{\mathrm{W}} 3.9$ earthquake; and b) May 6, 2013 (03:20 UTC) $M_{L} 3.5$ earthquake (U.S. Geological Survey, 2016). 
a)

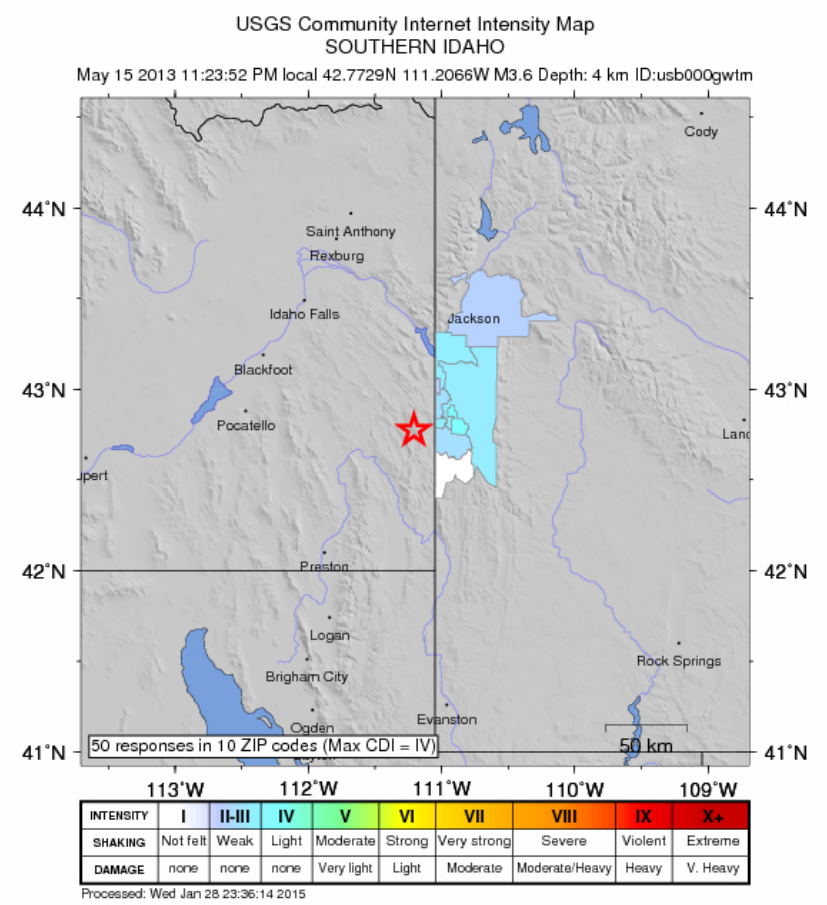

b)

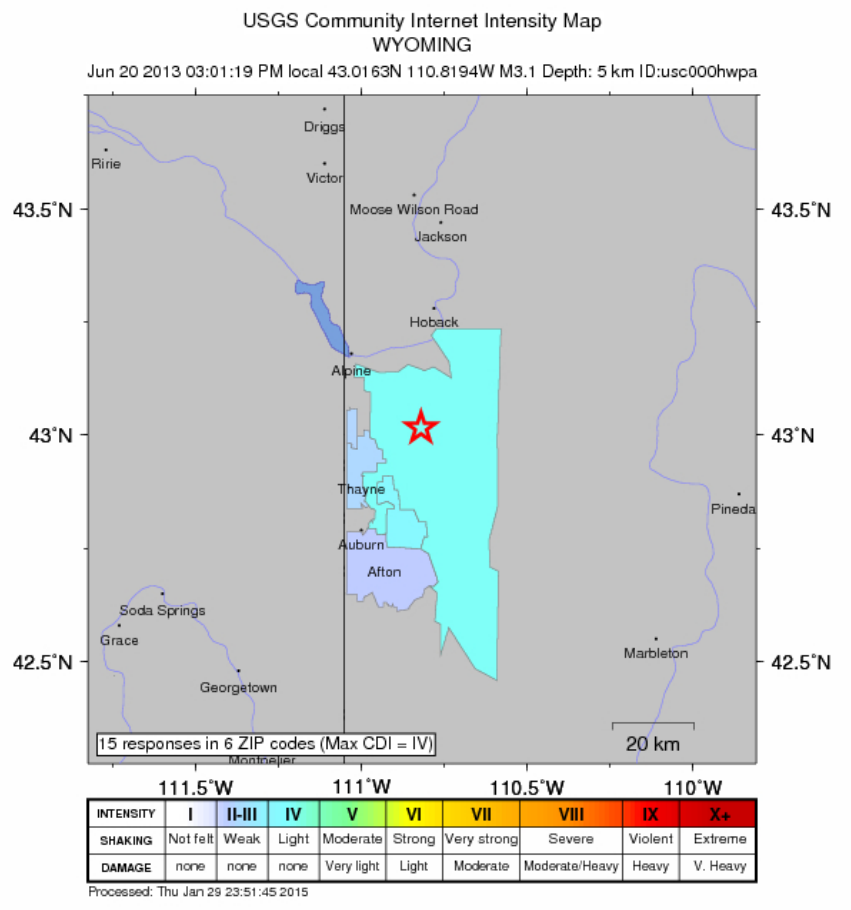

Figure B-3. Intensity maps for: a) May 16, 2013 (05:23 UTC) $\mathrm{M}_{\mathrm{W}} 3.6$ earthquake; and b) June 20, 2013 (21:01 UTC) $\mathrm{M}_{\mathrm{L}} 3.1$ earthquake (U.S. Geological Survey, 2016). 
a)

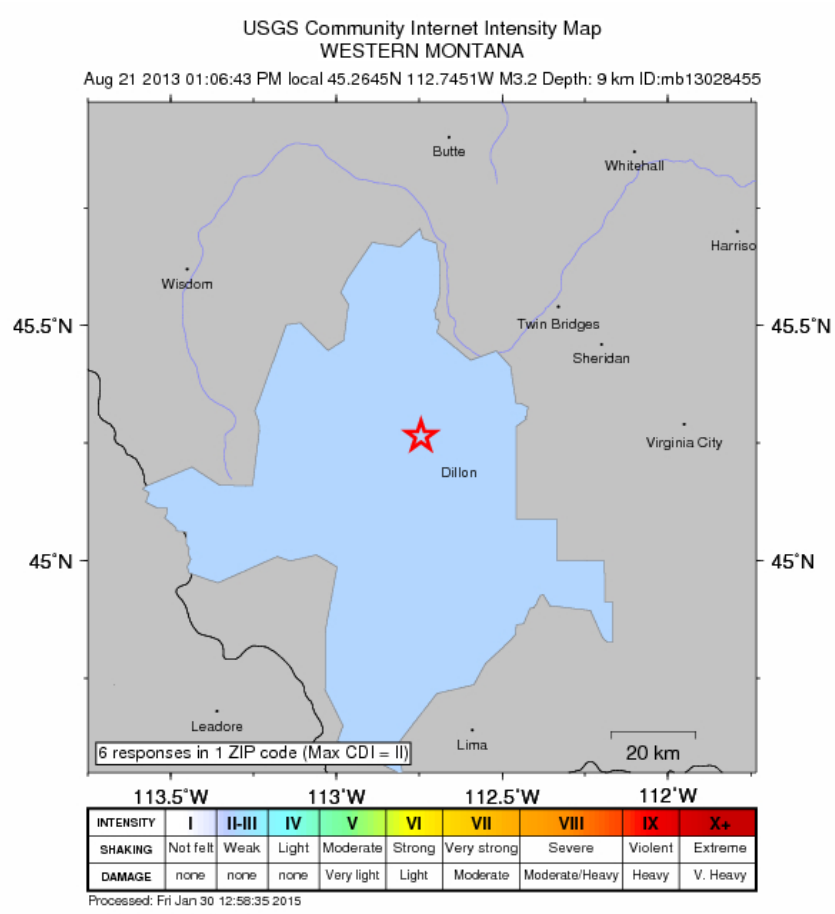

b)

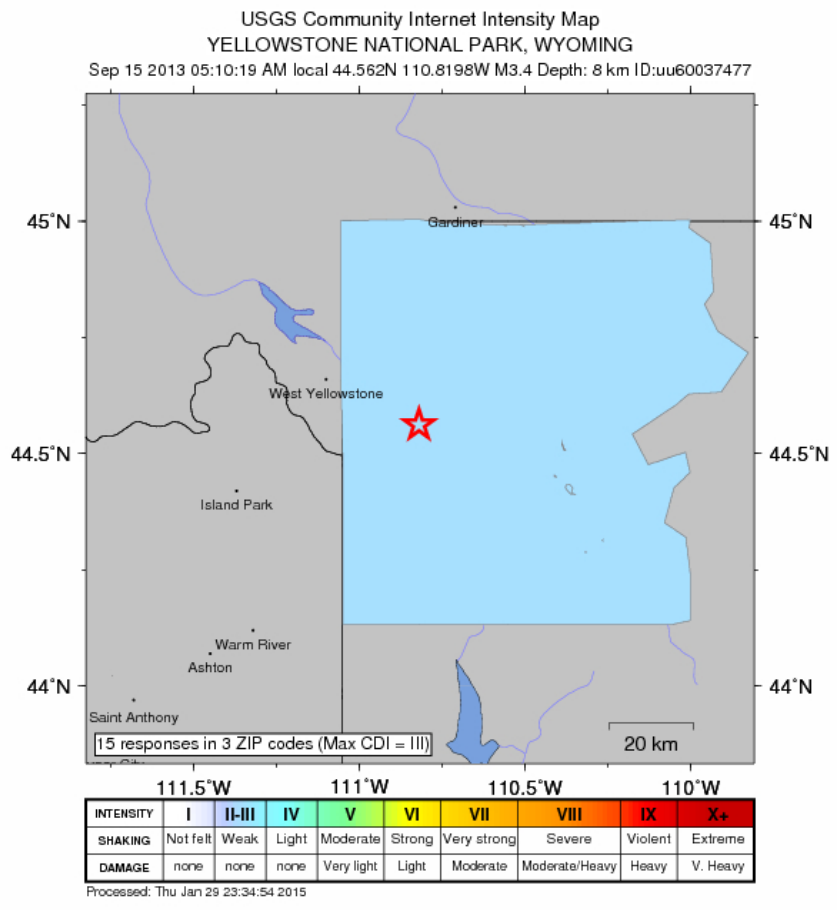

Figure B-4. Intensity maps for: a) August 21, 2013 (19:06 UTC) $\mathrm{M}_{\mathrm{L}} 3.3$ earthquake; and b) September 15, 2013 (11:10 UTC) $M_{\mathrm{L}} 3.4$ earthquake (U.S. Geological Survey, 2016). 
a)

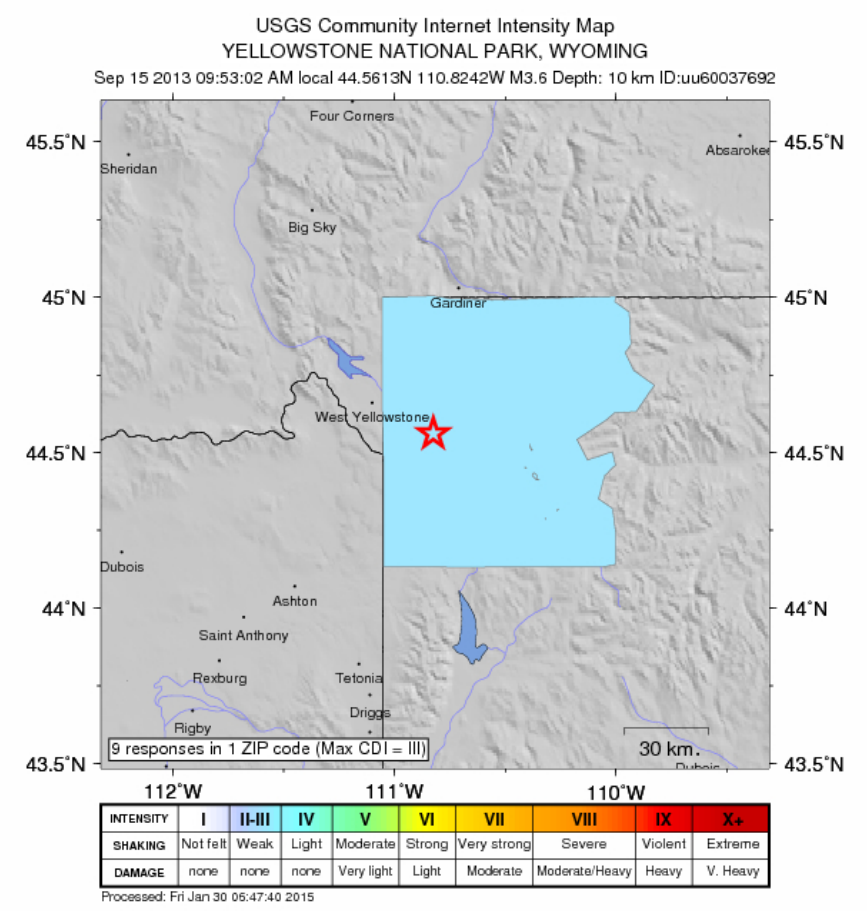

b)

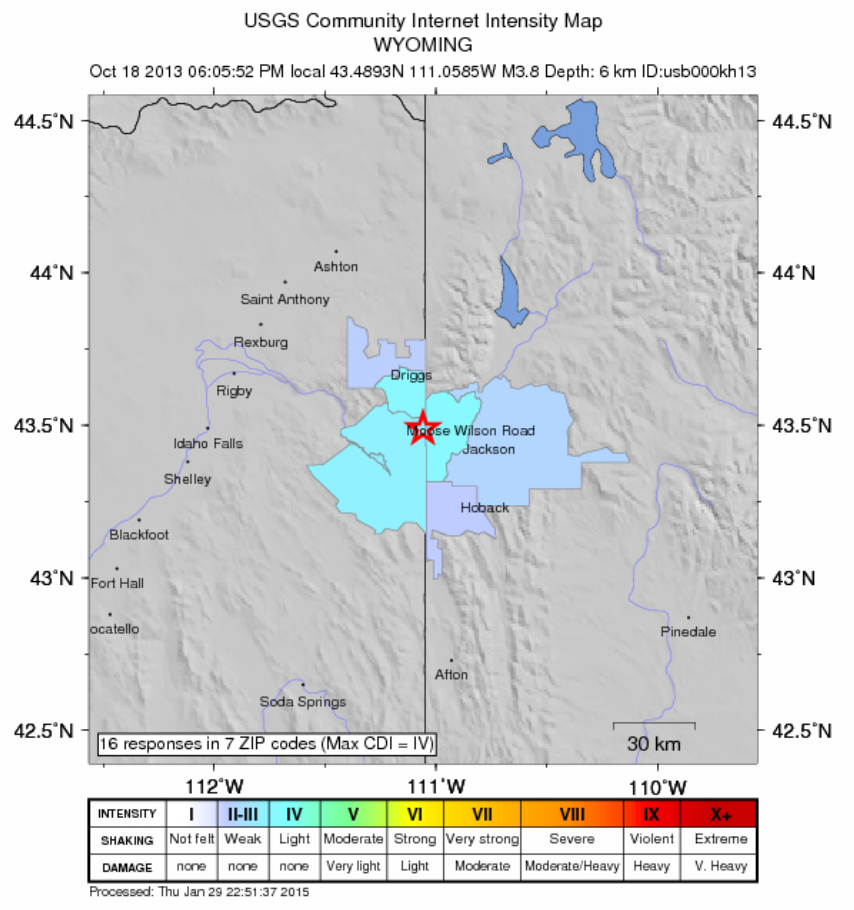

Figure B-5. Intensity maps for: a) September 15, 2013 (15:53 UTC) $\mathrm{M}_{\mathrm{L}} 3.6$ earthquake; and b) October 19, 2013 (00:05 UTC) $\mathrm{M}_{\mathrm{W}} 3.8$ earthquake (U.S. Geological Survey, 2016). 
a)

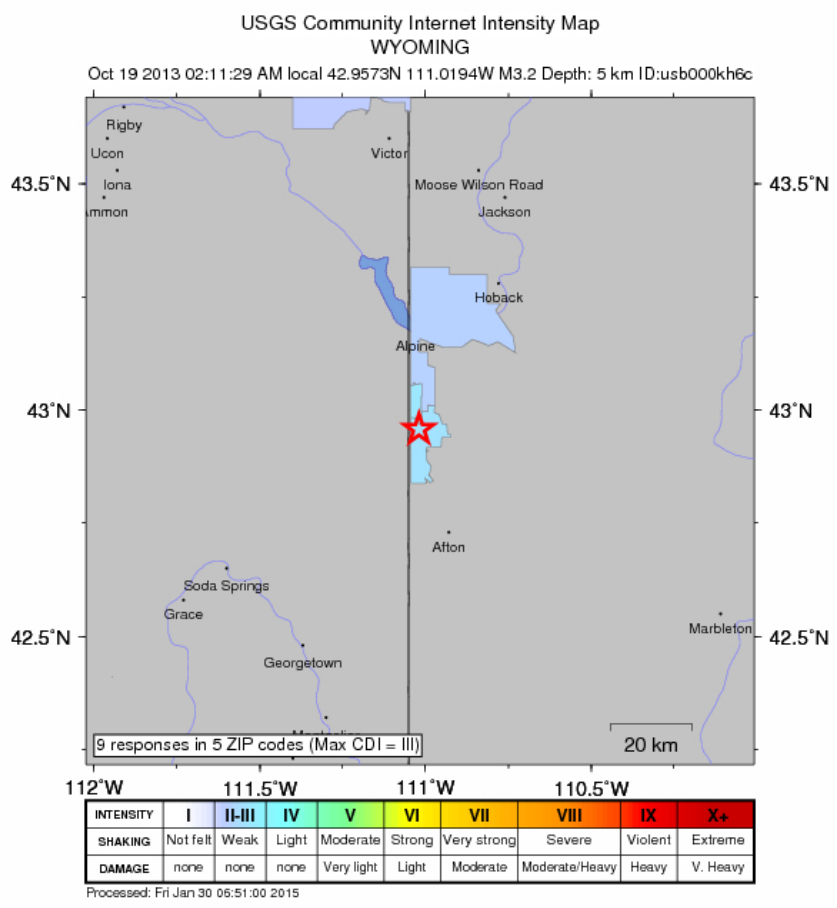

b)

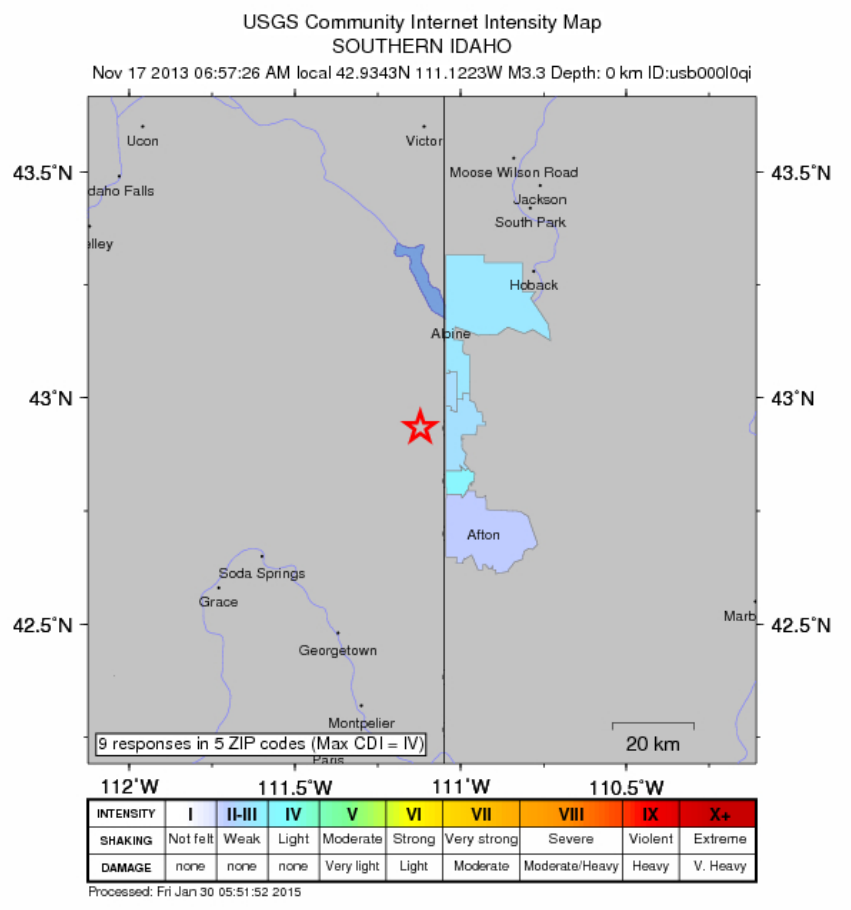

Figure B-6. Intensity maps for: a) October 19, 2013 (08:11 UTC) $\mathrm{M}_{\mathrm{L}} 3.3$ earthquake; and b) November 17, 2013 (13:57 UTC) $M_{\mathrm{L}} 3.3$ earthquake (U.S. Geological Survey, 2016). 
a)

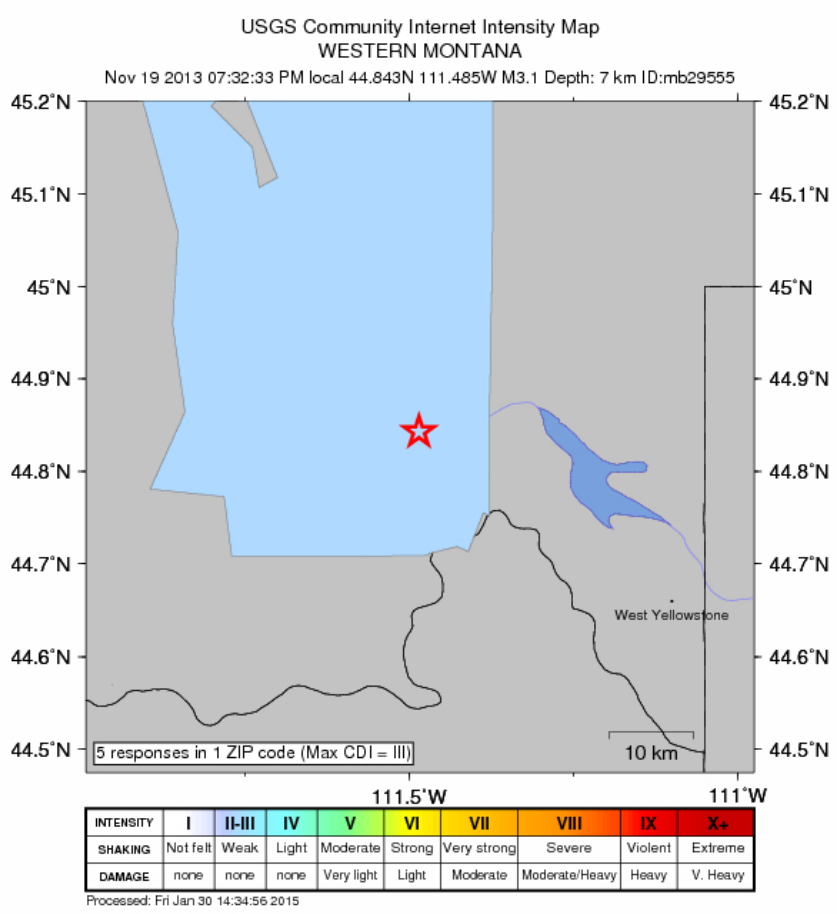

b)

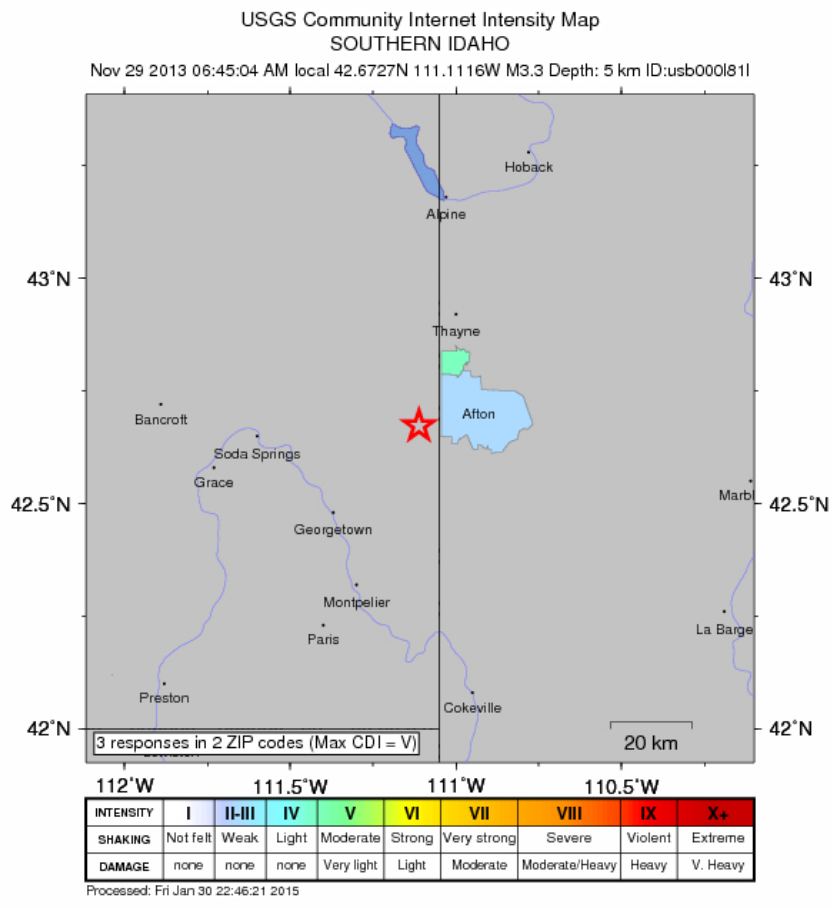

Figure B-7. Intensity maps for: a) November 20, 2013 (02:32 UTC) $\mathrm{M}_{\mathrm{c}} 3.1$ earthquake; and b) November 29, 2013 (13:45 UTC) $M_{\mathrm{L}} 3.1$ earthquake (U.S. Geological Survey, 2016). 
a)

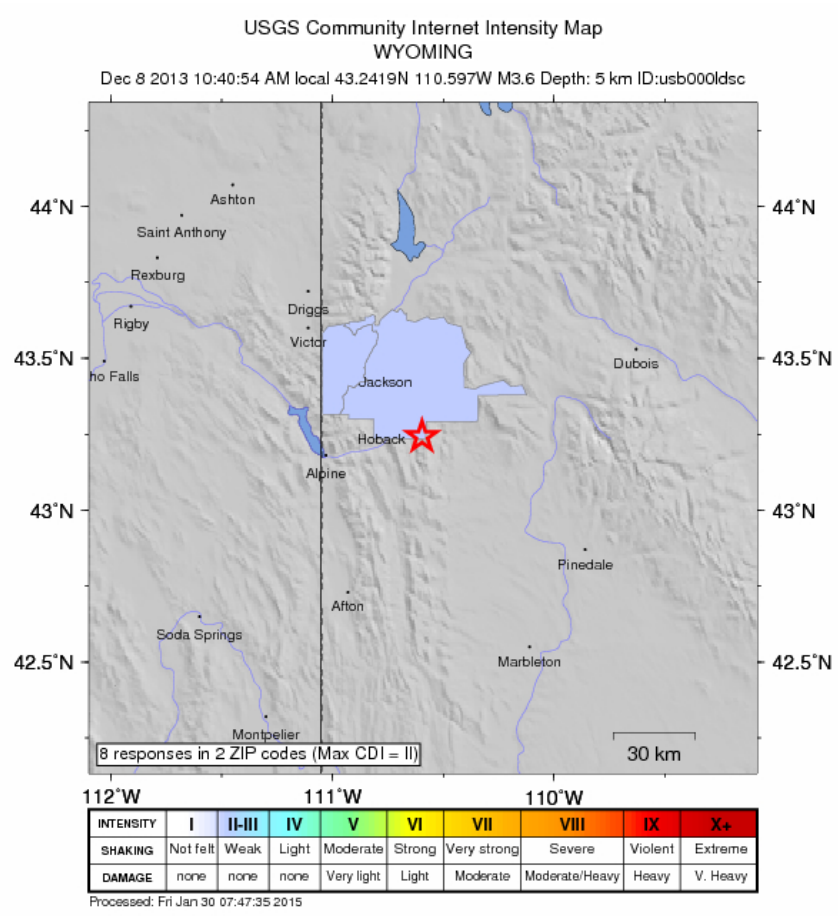

b)

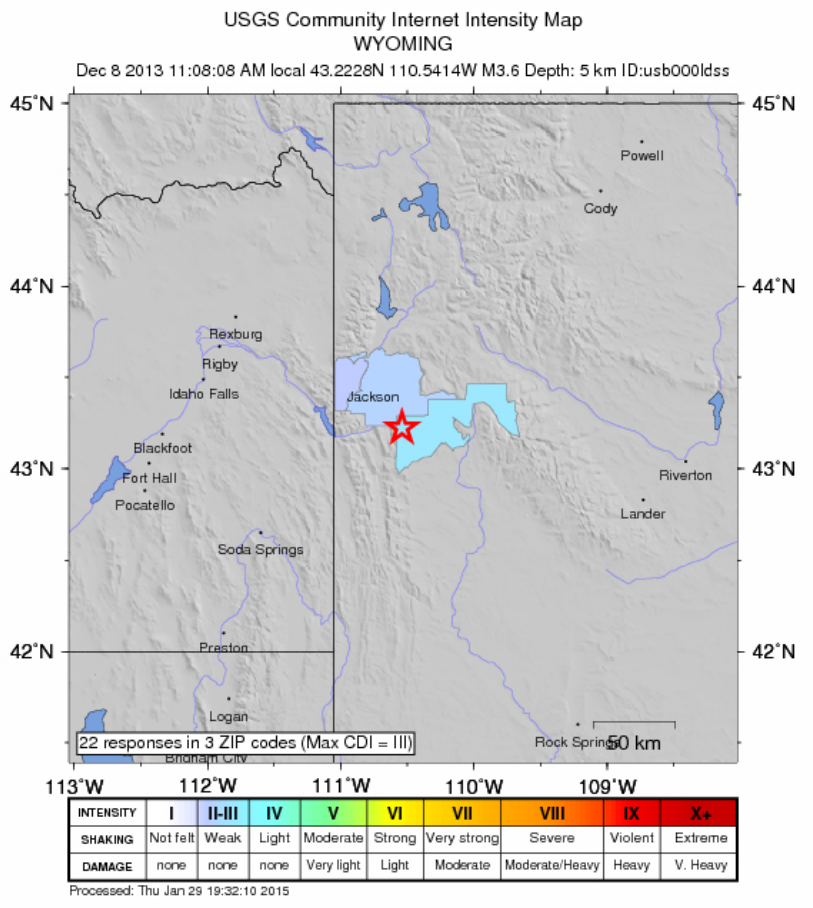

Figure B-8. Intensity maps for: a) December 8, 2013 (17:40 UTC) $\mathrm{M}_{\mathrm{L}} 3.6$ earthquake; and b) December 8, 2013 (18:08 UTC) $M_{\mathrm{L}} 3.9$ earthquake (U.S. Geological Survey, 2016). 
a)

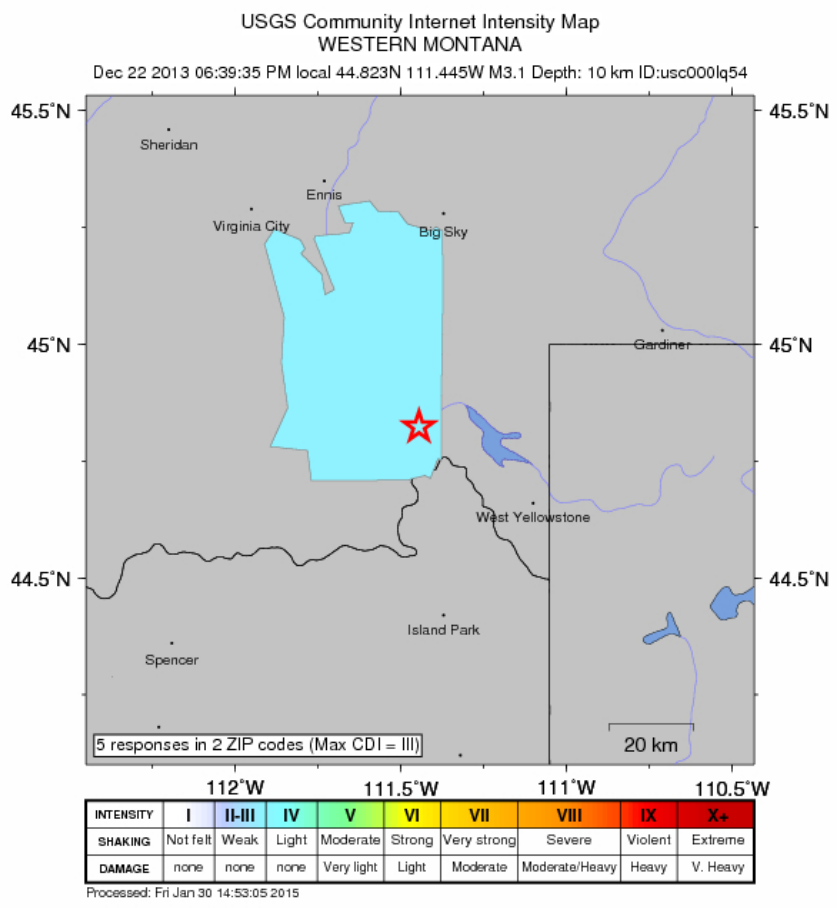

b)

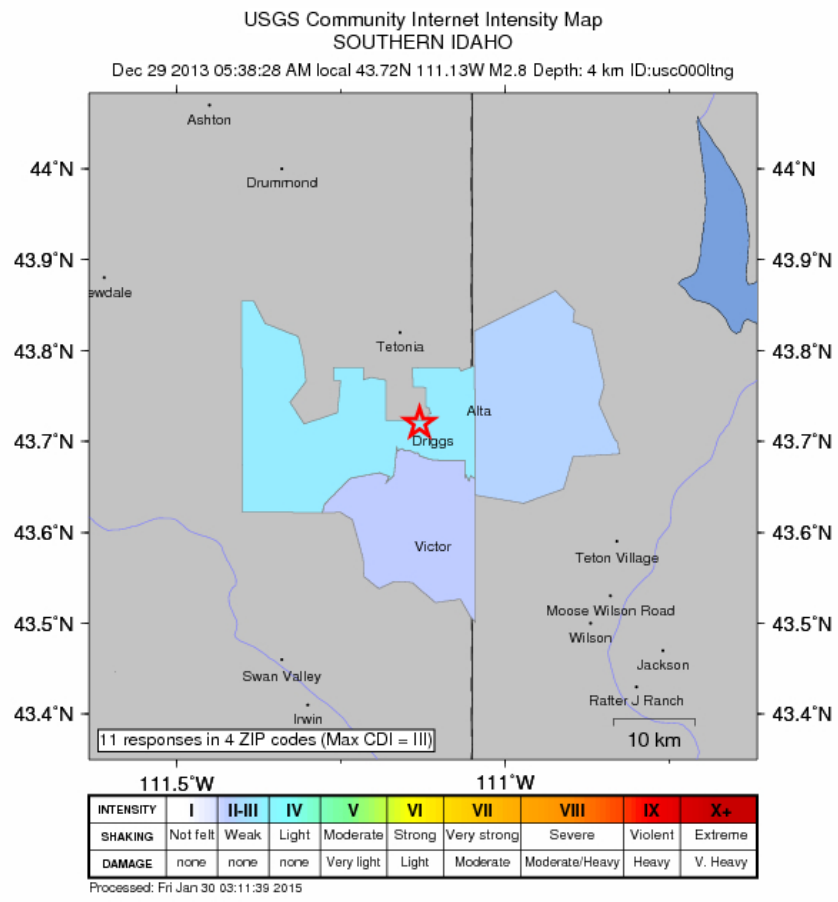

Figure B-9. Intensity maps for: a) December 23, 2013 (01:39 UTC) $\mathrm{M}_{\mathrm{L}} 2.8$ earthquake; and b) December 30, 2013 (00:38 UTC) $\mathrm{M}_{\mathrm{L}} 2.8$ earthquake (U.S. Geological Survey, 2016). 


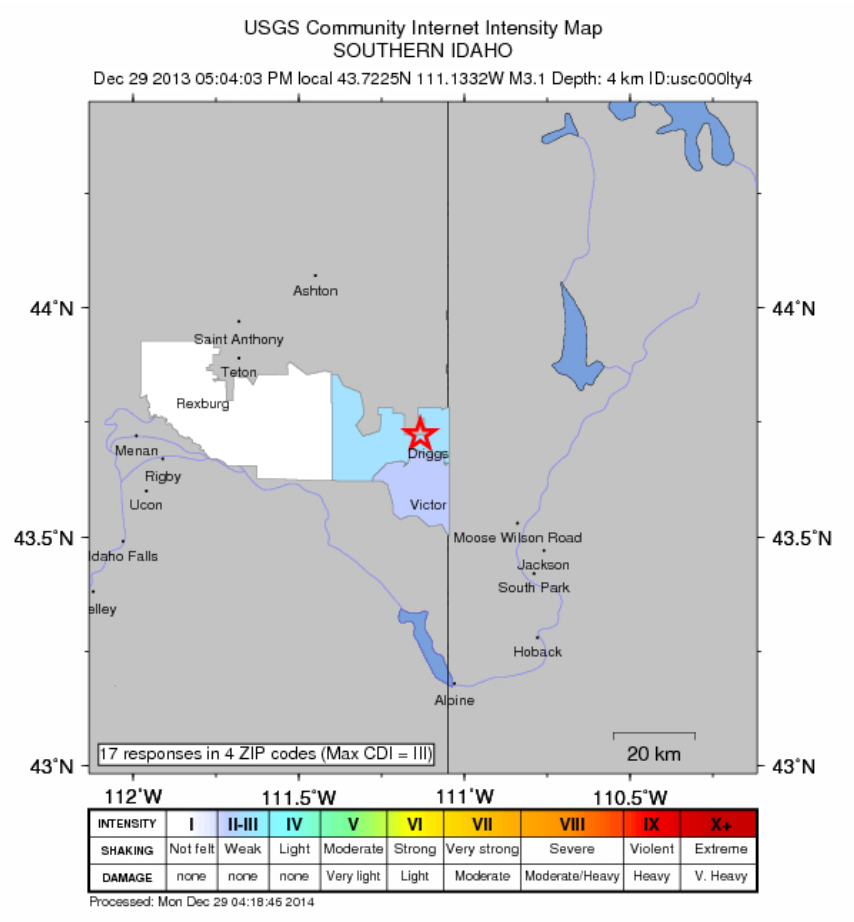

Figure B-10. Intensity maps for December 30, 2013 (00:40 UTC) $\mathrm{M}_{\mathrm{L}} 3.1$ earthquake (U.S. Geological Survey, 2016). 


\section{Appendix C}

\section{Earthquake List}

The summary list of earthquakes includes those located within a $161-\mathrm{km}(100-$ mile) radius of the INL centered at $43.0^{\circ} 39.00^{\prime} \mathrm{N}, 112^{\circ} 47.00^{\prime} \mathrm{W}$. Table C-1 provides an explanation of the headings listed in Table $\mathrm{C}-2$ for the earthquake list. 
Table C-1. Explanation of the earthquake summary table headings.

\begin{tabular}{|c|c|c|}
\hline Heading & Example & Explanation \\
\hline ORIGIN & $1 / 2 / 201300: 36: 13.6$ & $\begin{array}{l}\text { Date of the earthquake: month/day/year; origin time of the } \\
\text { earthquake: hour, minute, and second in UTC }\end{array}$ \\
\hline LAT N & 43.3002 & Latitude of epicenter in degrees North \\
\hline LONG W & -110.9658 & Longitude of epicenter in degrees West \\
\hline MAG- & 1.4 & $\begin{array}{l}\text { Magnitude of the earthquake. NM signifies that no magnitude } \\
\text { was determined for this earthquake. }\end{array}$ \\
\hline TYPE & ML IE & $\begin{array}{l}\text { Type of magnitude reported and reporting agency. Magnitude } \\
\text { types: Coda magnitude (Mc); Local magnitude (ML); } \\
\text { Moment magnitude (Mw); and Body wave magnitude (mb). } \\
\text { Reporting agencies include: Idaho National Laboratory (IE); } \\
\text { NEIC (US); University of Utah (UU); and Montana Bureau } \\
\text { of Mines and Geology (MB); Wyoming (WY). NM with a } \\
\text { magnitude of } 0.00 \text { indicates that no magnitude was calculated } \\
\text { as a result of multiple earthquakes, which obscures the coda } \\
\text { of the first event or the record length was insufficient to } \\
\text { include the full coda of the earthquake. }\end{array}$ \\
\hline DIST & 152.0 & $\begin{array}{l}\text { Distance in } \mathrm{km} \text { from center of INL at: } 43^{\circ} 39.00^{\prime} \mathrm{N} \\
112^{\circ} 47.00^{\prime} \mathrm{W} \text {. }\end{array}$ \\
\hline $\mathrm{Z}$ & 1.06 & $\begin{array}{l}\text { Calculated focal depth in } \mathrm{km} \text {. Not all earthquakes have } \\
\text { appropriate seismic station geometry for calculating a reliable } \\
\text { focal depth, thus the errors (ERZ) are typically large. }\end{array}$ \\
\hline NO & 9 & $\begin{array}{l}\text { Number of station readings used in locating the earthquake } \\
\text { with weights above } 0.1 . \mathrm{P} \text { - and S-wave arrival times for the } \\
\text { same station are regarded as two readings. }\end{array}$ \\
\hline GAP & 160 & Largest azimuthal separation in degrees between stations. \\
\hline DMIN & 11.5 & Distance in $\mathrm{km}$ from the epicenter to the nearest station. \\
\hline RMS & 0.04 & $\begin{array}{l}\text { Root mean square error of arrival time residuals in second } \\
\text { using all weights as calculated by: RMS }=\mathrm{SQRT}\left(\Sigma \mathrm{W}_{\mathrm{i}}{ }^{*} \mathrm{R}_{\mathrm{i}}{ }^{2} / \mathrm{N}\right) \\
\text { Where: SQRT is the square root; } \Sigma \mathrm{W}_{\mathrm{i}}^{*} \mathrm{R}_{\mathrm{i}} \text { is the sum of the } \\
\text { time residuals for the } \mathrm{i}^{\text {th }} \text { arrival times the weight assigned to } \\
\text { that arrival time; and } \mathrm{N} \text { is the number of residuals. }\end{array}$ \\
\hline ERH & 0.7 & Standard horizontal error of the epicenter in $\mathrm{km}$. \\
\hline ERZ & 1.6 & Standard vertical error of the focal depth in $\mathrm{km}$. \\
\hline
\end{tabular}


Table C-2. Earthquakes located within 161-km radius of INL in 2013.

\begin{tabular}{|c|c|c|c|c|c|c|c|c|c|c|c|c|}
\hline ORIGIN & TIME & LAT N & LONG W & MAG-TYP & DIST & Z & NO & GAP & DMIN & RMS & $\mathrm{ERH}$ & ERZ \\
\hline $1 / 2 / 2013$ & $00: 36: 13.6$ & 43.3002 & -110.9658 & 1.4 ML IE & 152.0 & 1.06 & 9 & 160 & 11.5 & 0.04 & 0.7 & 1.6 \\
\hline $1 / 2 / 2013$ & $05: 51: 14.4$ & 43.3807 & -111.0978 & 1.1 Mc IE & 139.4 & 3.74 & 10 & 175 & 17.0 & 0.04 & 0.9 & 6.6 \\
\hline $1 / 3 / 2013$ & $04: 44: 32.3$ & 43.7410 & -111.0918 & $0.3 \mathrm{ML}$ IE & 136.6 & 3.54 & 6 & 238 & 21.2 & 0.04 & 2.9 & 11.3 \\
\hline $1 / 3 / 2013$ & $11: 07: 58.5$ & 45.0268 & -112.3755 & 1.3 Mc MB & 156.6 & 1.09 & 7 & 144 & 41.1 & 0.02 & 1.2 & 3.9 \\
\hline $1 / 4 / 2013$ & 00:09:03.1 & 44.4780 & -112.1163 & 1.7 Mc IE & 106.5 & 4.74 & 20 & 106 & 22.1 & 0.03 & 0.3 & 0.6 \\
\hline $1 / 4 / 2013$ & $06: 09: 42.2$ & 43.6770 & -111.1420 & $0.5 \mathrm{ML}$ IE & 132.3 & 3.13 & 9 & 211 & 25.9 & 0.02 & 1.0 & 11.2 \\
\hline $1 / 4 / 2013$ & 07:04:04.0 & 42.8995 & -111.5100 & 1.1 ML IE & 132.8 & 6.72 & 12 & 114 & 36.7 & 0.07 & 0.5 & 3.9 \\
\hline $1 / 4 / 2013$ & 07:04:19.5 & 42.8965 & -111.4427 & $2.4 \mathrm{Mc} \mathrm{IE}$ & 137.3 & 7.98 & 9 & 181 & 31.6 & 0.04 & 0.8 & 2.4 \\
\hline $1 / 4 / 2013$ & $07: 44: 05.5$ & 44.0325 & -114.4967 & 1.3 Mc IE & 144.2 & 3.23 & 9 & 192 & 52.7 & 0.05 & 1.5 & 3.9 \\
\hline $1 / 4 / 2013$ & $14: 07: 04.3$ & 42.8858 & -111.5777 & 1.4 ML IE & 129.6 & 5.28 & 14 & 161 & 41.3 & 0.04 & 0.4 & 5.6 \\
\hline $1 / 4 / 2013$ & $14: 45: 37.4$ & 44.6115 & -112.5630 & 1.8 Mc MB & 108.4 & 8.65 & 11 & 99 & 13.5 & 0.02 & 0.6 & 3.3 \\
\hline $1 / 5 / 2013$ & $02: 34: 17.4$ & 43.8388 & -110.8957 & $0.5 \mathrm{ML}$ IE & 153.4 & 0.01 & 10 & 143 & 7.3 & 0.06 & 0.8 & 1.5 \\
\hline $1 / 5 / 2013$ & $04: 52: 30.0$ & 43.7113 & -111.0160 & $0.5 \mathrm{ML}$ IE & 142.6 & 2.49 & 8 & 179 & 21.5 & 0.05 & 0.9 & 12.4 \\
\hline $1 / 5 / 2013$ & $15: 10: 40.9$ & 45.0940 & -112.7162 & 1.3 Mc MB & 160.7 & 2.51 & 6 & 164 & 31.3 & 0.07 & 2.4 & 4.2 \\
\hline $1 / 8 / 2013$ & $20: 23: 07.6$ & 44.6033 & -112.1617 & $2.3 \mathrm{Mc} \mathrm{MB}$ & 117.1 & 5.26 & 14 & 91 & 18.5 & 0.03 & 0.6 & 0.9 \\
\hline $1 / 11 / 2013$ & $19: 57: 41.8$ & 43.2792 & -111.5485 & 1.2 ML IE & 108.0 & 16.69 & 18 & 123 & 29.0 & 0.10 & 0.4 & 0.6 \\
\hline $1 / 12 / 2013$ & $03: 32: 39.4$ & 43.5338 & -111.1262 & 1.1 ML IE & 134.3 & 9.24 & 8 & 188 & 15.0 & 0.08 & 1.0 & 2.6 \\
\hline $1 / 12 / 2013$ & $04: 29: 18.4$ & 43.5178 & -111.1405 & 1.4 ML IE & 133.4 & 11.61 & 15 & 87 & 15.7 & 0.04 & 0.4 & 1.4 \\
\hline $1 / 12 / 2013$ & $05: 17: 16.5$ & 43.5180 & -111.1315 & 1.2 ML IE & 134.1 & 8.70 & 7 & 230 & 15.0 & 0.01 & 1.1 & 2.3 \\
\hline $1 / 12 / 2013$ & $06: 13: 29.8$ & 42.9405 & -111.1978 & $0.8 \mathrm{ML}$ IE & 150.9 & 11.71 & 7 & 125 & 18.3 & 0.08 & 0.8 & 2.9 \\
\hline $1 / 12 / 2013$ & $23: 58: 54.5$ & 44.6208 & -112.0913 & 1.1 Mc MB & 121.3 & 3.61 & 5 & 138 & 24.3 & 0.02 & 1.1 & 2.1 \\
\hline $1 / 13 / 2013$ & $15: 12: 56.2$ & 44.6630 & -112.1565 & 2.6 Mc MB & 123.3 & 8.64 & 19 & 105 & 38.0 & 0.12 & 0.4 & 1.3 \\
\hline $1 / 13 / 2013$ & $15: 59: 32.9$ & 44.1462 & -113.9852 & 1.3 Mc IE & 111.2 & 2.50 & 13 & 220 & 49.1 & 0.06 & 0.8 & 3.8 \\
\hline $1 / 14 / 2013$ & $22: 54: 58.7$ & 42.6677 & -111.6720 & 1.0 ML IE & 141.8 & 4.99 & 7 & 113 & 48.1 & 0.06 & 0.7 & 12.3 \\
\hline $1 / 17 / 2013$ & $22: 33: 22.9$ & 44.3395 & -112.7302 & 1.1 Mc MB & 76.8 & 14.14 & 7 & 136 & 16.9 & 0.05 & 0.7 & 2.7 \\
\hline $1 / 18 / 2013$ & $05: 28: 11.7$ & 44.2880 & -114.1235 & 1.4 Mc IE & 128.8 & 6.53 & 9 & 250 & 57.4 & 0.05 & 2.2 & 6.0 \\
\hline $1 / 18 / 2013$ & $10: 28: 41.9$ & 43.7060 & -111.1693 & $0.4 \mathrm{Mc} \mathrm{IE}$ & 130.2 & 2.54 & 9 & 214 & 13.7 & 0.08 & 1.2 & 10.9 \\
\hline $1 / 18 / 2013$ & $13: 11: 21.7$ & 42.6798 & -111.6395 & $0.9 \mathrm{ML}$ IE & 142.4 & 4.80 & 9 & 94 & 33.8 & 0.05 & 0.6 & 6.9 \\
\hline $1 / 19 / 2013$ & $00: 24: 00.6$ & 43.2108 & -110.9585 & $0.6 \mathrm{ML}$ IE & 155.5 & 6.17 & 8 & 211 & 18.9 & 0.06 & 1.2 & 4.0 \\
\hline $1 / 19 / 2013$ & 02:26:01.9 & 44.7028 & -114.0935 & 1.5 Mc IE & 157.1 & 5.13 & 6 & 225 & 70.0 & 0.01 & 2.2 & 10.5 \\
\hline $1 / 19 / 2013$ & 05:00:04.6 & 44.6940 & -114.0645 & 1.6 ML IE & 154.9 & 5.11 & 5 & 247 & 67.5 & 0.02 & 2.2 & 12.3 \\
\hline $1 / 19 / 2013$ & $16: 01: 01.2$ & 42.8953 & -111.6375 & $0.6 \mathrm{ML}$ IE & 125.2 & 7.19 & 8 & 160 & 18.2 & 0.11 & 0.9 & 3.5 \\
\hline $1 / 19 / 2013$ & $17: 52: 40.5$ & 43.1583 & -111.4697 & $0.9 \mathrm{Mc}$ IE & 119.6 & 11.22 & 8 & 248 & 14.2 & 0.02 & 1.9 & 1.3 \\
\hline $1 / 19 / 2013$ & $22: 44: 23.8$ & 42.5407 & -111.5855 & 1.3 ML IE & 157.2 & 6.82 & 12 & 98 & 46.1 & 0.04 & 0.4 & 4.0 \\
\hline $1 / 20 / 2013$ & 01:14:02.9 & 43.1598 & -111.3745 & 1.1 ML IE & 126.4 & 6.72 & 11 & 194 & 11.8 & 0.05 & 0.8 & 2.1 \\
\hline $1 / 20 / 2013$ & $10: 55: 50.2$ & 43.1483 & -110.9880 & $0.5 \mathrm{Mc}$ IE & 155.7 & 5.89 & 9 & 164 & 26.2 & 0.07 & 1.4 & 6.0 \\
\hline $1 / 21 / 2013$ & $02: 23: 28.9$ & 44.8203 & -112.9800 & 1.7 Mc IE & 131.1 & 5.49 & 14 & 175 & 10.4 & 0.05 & 0.7 & 0.6 \\
\hline $1 / 21 / 2013$ & $14: 38: 00.4$ & 44.6970 & -111.8915 & 1.4 Mc MB & 136.6 & 9.04 & 10 & 114 & 18.3 & 0.02 & 0.5 & 2.5 \\
\hline $1 / 22 / 2013$ & 05:05:16.8 & 42.7307 & -111.7820 & $0.7 \mathrm{ML}$ IE & 130.7 & 3.24 & 10 & 108 & 49.2 & 0.03 & 0.4 & 12.0 \\
\hline $1 / 23 / 2013$ & $00: 30: 44.5$ & 43.7380 & -111.0548 & $0.6 \mathrm{ML}$ IE & 139.6 & 1.78 & 12 & 181 & 11.3 & 0.06 & 1.0 & 1.9 \\
\hline $1 / 24 / 2013$ & $20: 07: 44.4$ & 44.0903 & -113.9430 & 2.1 Mc IE & 105.3 & 6.99 & 12 & 207 & 43.3 & 0.09 & 0.8 & 14.8 \\
\hline $1 / 27 / 2013$ & 09:18:44.3 & 42.9163 & -111.1548 & 1.0 ML IE & 155.3 & 3.11 & 10 & 136 & 17.4 & 0.10 & 0.5 & 12.6 \\
\hline $1 / 27 / 2013$ & $18: 29: 25.4$ & 43.3678 & -111.1232 & 1.3 ML IE & 137.8 & 10.86 & 9 & 163 & 22.0 & 0.08 & 0.6 & 2.9 \\
\hline $1 / 29 / 2013$ & $12: 23: 33.7$ & 44.1602 & -113.1270 & $0.6 \mathrm{ML}$ IE & 63.1 & 4.35 & 10 & 172 & 18.7 & 0.08 & 0.6 & 1.6 \\
\hline $1 / 29 / 2013$ & $19: 37: 07.8$ & 44.2580 & -114.0970 & 1.4 Mc IE & 125.2 & 3.91 & 9 & 245 & 55.5 & 0.06 & 0.9 & 2.9 \\
\hline $1 / 31 / 2013$ & $15: 45: 03.1$ & 43.2443 & -113.0368 & 1.3 Mc IE & 49.6 & 45.00 & 9 & 143 & 16.6 & 0.09 & 1.0 & 0.9 \\
\hline $2 / 1 / 2013$ & $06: 15: 38.1$ & 43.9170 & -113.6187 & $0.8 \mathrm{ML}$ IE & 73.5 & 6.33 & 11 & 204 & 13.5 & 0.09 & 0.9 & 0.7 \\
\hline $2 / 2 / 2013$ & $14: 45: 32.4$ & 43.3122 & -110.9175 & 1.8 Mc IE & 155.5 & 3.18 & 14 & 151 & 7.7 & 0.06 & 0.6 & 3.3 \\
\hline $2 / 2 / 2013$ & $15: 11: 54.9$ & 43.3015 & -110.8985 & $2.2 \mathrm{Mc} \mathrm{IE}$ & 157.2 & 6.25 & 11 & 162 & 7.7 & 0.04 & 0.7 & 1.3 \\
\hline $2 / 2 / 2013$ & $15: 15: 43.4$ & 43.3055 & -110.9053 & 1.7 ML IE & 156.6 & 5.80 & 14 & 112 & 7.7 & 0.05 & 0.6 & 1.1 \\
\hline
\end{tabular}


Table C-2. Continued.

\begin{tabular}{|c|c|c|c|c|c|c|c|c|c|c|c|c|}
\hline ORIGIN & TIME & LAT N & LONG W & MAG-TYP & DIST & Z & NO & GAP & DMIN & RMS & $\mathrm{ERH}$ & ERZ \\
\hline $2 / 2 / 2013$ & $15: 32: 15.2$ & 43.2970 & -110.8943 & 2.1 ML IE & 157.7 & 5.80 & 13 & 117 & 8.0 & 0.06 & 0.8 & 1.2 \\
\hline $2 / 2 / 2013$ & $16: 18: 03.6$ & 43.3397 & -110.8987 & 1.1 ML IE & 156.2 & 2.90 & 8 & 139 & 4.6 & 0.02 & 0.8 & 2.8 \\
\hline $2 / 3 / 2013$ & $09: 41: 36.6$ & 44.4708 & -114.2450 & $1.3 \mathrm{Mc} \mathrm{IE}$ & 148.5 & 1.32 & 7 & 241 & 69.2 & 0.05 & 1.6 & 3.4 \\
\hline $2 / 3 / 2013$ & $12: 21: 42.3$ & 43.3002 & -110.9070 & 1.1 ML IE & 156.6 & 4.65 & 9 & 160 & 8.2 & 0.08 & 0.8 & 1.9 \\
\hline $2 / 3 / 2013$ & 13:01:03.0 & 43.3205 & -110.8863 & 1.4 ML IE & 157.7 & 4.29 & 12 & 161 & 5.4 & 0.05 & 0.6 & 1.1 \\
\hline $2 / 3 / 2013$ & $15: 44: 54.7$ & 43.2938 & -110.9025 & 1.0 ML IE & 157.2 & 4.96 & 7 & 162 & 8.7 & 0.05 & 0.9 & 1.9 \\
\hline $2 / 3 / 2013$ & $22: 42: 53.0$ & 44.5250 & -114.3202 & $2.2 \mathrm{Mc} M B$ & 156.9 & 9.12 & 7 & 137 & 76.7 & 0.05 & 0.8 & 2.2 \\
\hline $2 / 4 / 2013$ & $02: 27: 32.1$ & 43.9947 & -114.4082 & 1.4 Mc IE & 136.2 & 7.25 & 8 & 247 & 48.0 & 0.07 & 1.1 & 13.7 \\
\hline $2 / 4 / 2013$ & $08: 32: 27.8$ & 44.6542 & -112.5405 & 1.3 Mc MB & 113.4 & 6.42 & 7 & 171 & 13.4 & 0.06 & 1.4 & 9.4 \\
\hline $2 / 4 / 2013$ & $10: 42: 10.5$ & 44.5607 & -114.3025 & $1.6 \mathrm{Mc} \mathrm{IE}$ & 158.3 & 1.78 & 10 & 250 & 76.7 & 0.11 & 1.2 & 4.6 \\
\hline $2 / 5 / 2013$ & 02:06:28.5 & 44.1755 & -113.0652 & $0.4 \mathrm{Mc} \mathrm{IE}$ & 62.7 & 4.98 & 10 & 90 & 15.8 & 0.09 & 0.5 & 1.0 \\
\hline $2 / 6 / 2013$ & $13: 19: 50.4$ & 44.1610 & -111.1155 & $0.2 \mathrm{Mc} \mathrm{IE}$ & 145.4 & 13.37 & 6 & 148 & 6.3 & 0.05 & 1.3 & 3.2 \\
\hline $2 / 6 / 2013$ & $15: 00: 41.5$ & 43.2985 & -111.0777 & 1.3 ML IE & 143.3 & 2.77 & 11 & 154 & 19.6 & 0.06 & 0.5 & 11.4 \\
\hline $2 / 11 / 2013$ & $11: 22: 40.1$ & 44.4493 & -112.0028 & 1.1 Mc MB & 108.7 & 6.26 & 9 & 112 & 35.0 & 0.05 & 0.5 & 13.0 \\
\hline $2 / 12 / 2013$ & $14: 01: 59.0$ & 44.6225 & -112.1093 & $1.2 \mathrm{Mc} 1$ & 120.9 & 12.91 & 11 & 95 & 22.9 & 0.03 & 0.4 & 1.1 \\
\hline $2 / 14 / 2013$ & $18: 35: 16.8$ & 42.6655 & -111.8417 & 2.0 ML IE & 133.6 & 4.25 & 16 & 99 & 45.8 & 0.07 & 0.3 & 9.8 \\
\hline $2 / 16 / 2013$ & $05: 11: 28.3$ & 43.0008 & -111.3077 & $0.9 \mathrm{ML}$ IE & 139.7 & 4.84 & 10 & 104 & 7.8 & 0.07 & 0.6 & 2.9 \\
\hline $2 / 16 / 2013$ & $16: 25: 18.8$ & 42.9365 & -111.4770 & 1.3 ML IE & 132.4 & 0.02 & 12 & 261 & 4.5 & 0.05 & 0.9 & 0.5 \\
\hline $2 / 18 / 2013$ & $12: 55: 05.8$ & 44.4047 & -113.0537 & $0.6 \mathrm{ML}$ IE & 86.7 & 6.87 & 12 & 129 & 12.3 & 0.05 & 0.4 & 0.7 \\
\hline $2 / 19 / 2013$ & $11: 16: 25.7$ & 43.4897 & -113.6150 & 0.7 ML IE & 69.5 & 37.17 & 6 & 224 & 3.5 & 0.09 & 1.8 & 1.3 \\
\hline $2 / 19 / 2013$ & $23: 46: 38.1$ & 43.5370 & -110.9843 & $2.0 \mathrm{Mc} \mathrm{IE}$ & 145.7 & 0.02 & 19 & 133 & 5.9 & 0.12 & 0.4 & 0.5 \\
\hline 2/19/2013 & $23: 57: 55.8$ & 43.5387 & -110.9775 & 1.5 ML IE & 146.2 & 0.02 & 13 & 132 & 5.8 & 0.11 & 0.8 & 0.8 \\
\hline $2 / 20 / 2013$ & $15: 57: 35.2$ & 44.3505 & -114.0195 & 1.1 Mc IE & 126.1 & 5.39 & 8 & 219 & 49.2 & 0.03 & 0.9 & 4.0 \\
\hline $2 / 22 / 2013$ & $13: 04: 05.3$ & 44.7477 & -111.6628 & 1.2 Mc MB & 151.4 & 6.26 & 10 & 217 & 2.0 & 0.02 & 2.0 & 0.4 \\
\hline $2 / 23 / 2013$ & 05:39:08.6 & 44.3650 & -112.7023 & $1.5 \mathrm{Mc} \mathrm{MB}$ & 79.8 & 6.27 & 28 & 83 & 19.4 & 0.06 & 0.2 & 0.6 \\
\hline $2 / 23 / 2013$ & $05: 45: 18.0$ & 44.3638 & -112.7023 & 1.0 Mc MB & 79.7 & 4.67 & 18 & 83 & 19.4 & 0.07 & 0.4 & 0.8 \\
\hline 2/23/2013 & $05: 50: 53.7$ & 44.3600 & -112.6983 & $0.9 \mathrm{ML}$ IE & 79.3 & 4.92 & 14 & 83 & 19.7 & 0.05 & 0.4 & 0.9 \\
\hline $2 / 25 / 2013$ & $19: 15: 50.7$ & 44.6280 & -112.0773 & 1.6 Mc MB & 122.6 & 5.95 & 12 & 139 & 25.5 & 0.04 & 0.6 & 11.5 \\
\hline $2 / 26 / 2013$ & $12: 22: 26.3$ & 44.2418 & -114.0225 & 1.1 Mc IE & 119.3 & 6.95 & 10 & 237 & 49.9 & 0.03 & 1.1 & 12.8 \\
\hline $2 / 28 / 2013$ & $16: 52: 30.4$ & 42.6550 & -111.3745 & $0.8 \mathrm{Mc}$ IE & 159.3 & 2.63 & 6 & 293 & 25.6 & 0.03 & 2.5 & 12.1 \\
\hline $3 / 1 / 2013$ & $00: 57: 17.3$ & 43.4897 & -110.8413 & $0.9 \mathrm{Mc} \mathrm{IE}$ & 157.8 & 3.85 & 4 & 230 & 14.2 & 0.27 & 7.3 & 24.5 \\
\hline $3 / 1 / 2013$ & $04: 28: 55.4$ & 44.6393 & -111.8720 & 1.2 Mc MB & 132.0 & 0.04 & 12 & 132 & 19.2 & 0.04 & 0.4 & 1.0 \\
\hline $3 / 2 / 2013$ & $18: 22: 05.2$ & 43.2003 & -111.3883 & $0.9 \mathrm{Mc} \mathrm{IE}$ & 123.5 & 2.50 & 6 & 216 & 16.4 & 0.14 & 1.3 & 16.8 \\
\hline $3 / 2 / 2013$ & 21:10:04.7 & 43.5388 & -111.1388 & 1.1 ML IE & 133.3 & 8.44 & 7 & 251 & 14.3 & 0.02 & 2.0 & 1.8 \\
\hline $3 / 2 / 2013$ & $21: 12: 31.7$ & 43.5587 & -111.1507 & $0.8 \mathrm{Mc} \mathrm{IE}$ & 132.1 & 11.28 & 6 & 277 & 13.3 & 0.07 & 0.9 & 1.8 \\
\hline $3 / 2 / 2013$ & $22: 46: 19.5$ & 44.5282 & -113.9728 & 1.6 Mc IE & 136.4 & 9.67 & 4 & 282 & 51.3 & 0.31 & 10.8 & 26.9 \\
\hline $3 / 2 / 2013$ & $23: 34: 14.5$ & 43.3437 & -110.8388 & $0.1 \mathrm{Mc} \mathrm{IE}$ & 160.8 & 6.90 & 4 & 357 & 2.3 & 0.00 & 12.5 & 1.1 \\
\hline $3 / 3 / 2013$ & $12: 14: 29.8$ & 44.2785 & -112.8800 & $0.3 \mathrm{Mc} \mathrm{IE}$ & 70.3 & 4.76 & 8 & 89 & 7.5 & 0.01 & 0.5 & 0.7 \\
\hline $3 / 5 / 2013$ & $07: 30: 40.9$ & 43.4478 & -111.0895 & $0.9 \mathrm{Mc} \mathrm{IE}$ & 138.6 & 2.83 & 7 & 257 & 12.2 & 0.38 & 3.3 & 32.4 \\
\hline $3 / 5 / 2013$ & $10: 00: 06.8$ & 43.2157 & -111.3180 & $0.4 \mathrm{Mc} \mathrm{IE}$ & 128.0 & 5.00 & 4 & 320 & 41.2 & 0.06 & 2.9 & 13.1 \\
\hline $3 / 6 / 2013$ & $21: 43: 37.2$ & 42.8583 & -111.1365 & $0.6 \mathrm{ML} \mathrm{IE}$ & 160.1 & 9.82 & 8 & 136 & 10.8 & 0.03 & 0.6 & 1.6 \\
\hline $3 / 7 / 2013$ & $11: 37: 21.2$ & 43.3292 & -111.1233 & 1.8 Mc IE & 138.8 & 2.53 & 15 & 144 & 22.3 & 0.06 & 0.4 & 10.9 \\
\hline $3 / 9 / 2013$ & $03: 42: 32.2$ & 44.5870 & -112.5852 & $1.5 \mathrm{Mc} \mathrm{MB}$ & 105.4 & 4.06 & 8 & 124 & 15.2 & 0.05 & 1.8 & 3.5 \\
\hline $3 / 9 / 2013$ & $18: 40: 22.9$ & 43.5250 & -111.0112 & $0.9 \mathrm{ML} \mathrm{IE}$ & 143.7 & 4.05 & 8 & 227 & 6.2 & 0.06 & 1.3 & 3.6 \\
\hline $3 / 12 / 2013$ & $06: 55: 46.8$ & 44.0027 & -114.4517 & 1.1 Mc IE & 139.8 & 5.18 & 10 & 279 & 49.0 & 0.02 & 6.1 & 10.1 \\
\hline $3 / 12 / 2013$ & $07: 49: 50.2$ & 44.1055 & -114.6343 & 1.1 Mc IE & 157.1 & 0.02 & 6 & 273 & 63.1 & 0.02 & 8.3 & 9.5 \\
\hline $3 / 14 / 2013$ & $00: 46: 54.1$ & 43.2290 & -111.3532 & 1.6 Mc IE & 124.8 & 3.15 & 23 & 89 & 19.5 & 0.10 & 0.4 & 6.6 \\
\hline $3 / 14 / 2013$ & 03:01:48.9 & 42.8393 & -111.2440 & 1.4 ML IE & 154.1 & 12.33 & 9 & 184 & 14.3 & 0.09 & 0.9 & 1.2 \\
\hline $3 / 14 / 2013$ & 03:07:03.0 & 42.8465 & -111.2292 & $0.6 \mathrm{ML}$ IE & 154.6 & 12.30 & 8 & 173 & 13.9 & 0.12 & 0.7 & 1.3 \\
\hline $3 / 17 / 2013$ & 13:59:04.0 & 44.0837 & -114.5147 & 1.7 ML IE & 147.3 & 6.81 & 8 & 262 & 58.6 & 0.08 & 1.7 & 5.1 \\
\hline $3 / 20 / 2013$ & 04:49:10.4 & 42.7198 & -111.4035 & 1.0 ML IE & 152.6 & 7.18 & 8 & 279 & 24.3 & 0.03 & 1.4 & 3.1 \\
\hline
\end{tabular}


Table C-2. Continued.

\begin{tabular}{|c|c|c|c|c|c|c|c|c|c|c|c|c|}
\hline ORIGIN & TIME & LAT N & LONG W & MAG-TYP & DIST & Z & NO & GAP & DMIN & RMS & $\mathrm{ERH}$ & ERZ \\
\hline $3 / 20 / 2013$ & $20: 36: 32.2$ & 44.8258 & -112.9177 & 1.8 ML IE & 131.2 & 5.90 & 10 & 167 & 5.4 & 0.06 & 0.7 & 0.3 \\
\hline $3 / 21 / 2013$ & 01:10:57.7 & 42.8525 & -111.2335 & 2.1 Mc IE & 153.9 & 9.33 & 15 & 100 & 14.6 & 0.07 & 0.4 & 1.1 \\
\hline $3 / 21 / 2013$ & $05: 27: 30.7$ & 44.7218 & -113.6432 & 1.4 Mc MB & 137.6 & 2.89 & 7 & 233 & 64.0 & 0.02 & 1.8 & 4.4 \\
\hline $3 / 21 / 2013$ & $05: 34: 16.7$ & 44.7297 & -113.6427 & 1.7 ML IE & 138.4 & 1.46 & 9 & 233 & 63.8 & 0.05 & 1.5 & 2.4 \\
\hline $3 / 21 / 2013$ & $10: 38: 52.9$ & 42.8482 & -111.2367 & 1.2 ML IE & 154.0 & 9.94 & 8 & 175 & 14.5 & 0.08 & 0.8 & 2.1 \\
\hline $3 / 21 / 2013$ & $23: 17: 58.0$ & 43.2765 & -111.5515 & 1.1 ML IE & 107.9 & 3.64 & 8 & 231 & 28.8 & 0.07 & 1.5 & 11.3 \\
\hline $3 / 22 / 2013$ & $00: 03: 25.8$ & 43.2683 & -111.5173 & 1.7 ML IE & 110.8 & 2.50 & 16 & 71 & 26.7 & 0.11 & 0.4 & 14.4 \\
\hline $3 / 22 / 2013$ & $00: 44: 28.9$ & 43.2195 & -111.5193 & $0.5 \mathrm{ML}$ IE & 112.9 & 5.02 & 4 & 254 & 22.1 & 0.05 & 2.3 & 11.1 \\
\hline $3 / 22 / 2013$ & $23: 00: 12.6$ & 43.5462 & -111.1735 & 1.8 ML IE & 130.4 & 8.89 & 11 & 188 & 15.6 & 0.06 & 0.7 & 2.0 \\
\hline 3/23/2013 & $00: 47: 03.8$ & 43.5542 & -111.1965 & $0.7 \mathrm{Mc}$ IE & 128.5 & 5.22 & 5 & 288 & 16.6 & 0.05 & 3.0 & 12.8 \\
\hline $3 / 26 / 2013$ & 03:27:19.4 & 44.5042 & -112.7532 & $2.6 \mathrm{Mc} \mathrm{IE}$ & 95.1 & 0.01 & 19 & 110 & 24.5 & 0.18 & 0.6 & 1.9 \\
\hline $3 / 26 / 2013$ & $05: 02: 10.7$ & 43.7783 & -110.8113 & $0.0 \mathrm{Mc} \mathrm{IE}$ & 159.5 & 5.00 & 4 & 268 & 23.3 & 1.64 & 15.6 & 98.9 \\
\hline $3 / 26 / 2013$ & 05:06:50.9 & 44.4960 & -112.7043 & 1.6 Mc IE & 94.3 & 5.01 & 4 & 194 & 38.6 & 0.02 & 1.3 & 11.5 \\
\hline $3 / 26 / 2013$ & $14: 38: 53.4$ & 43.6963 & -110.8478 & $0.5 \mathrm{Mc} \mathrm{IE}$ & 156.1 & 2.01 & 6 & 229 & 15.8 & 0.05 & 1.5 & 13.1 \\
\hline $3 / 27 / 2013$ & $04: 45: 15.7$ & 42.5292 & -111.6158 & 1.1 Mc IE & 156.7 & 4.81 & 3 & 264 & 49.8 & 0.15 & 2.5 & 17.6 \\
\hline $3 / 28 / 2013$ & 05:08:39.8 & 43.5328 & -111.1915 & $0.6 \mathrm{Mc}$ IE & 129.1 & 4.82 & 7 & 284 & 17.7 & 0.08 & 1.0 & 4.6 \\
\hline $3 / 28 / 2013$ & $07: 44: 35.3$ & 44.3028 & -112.8590 & 1.7 Mc IE & 72.9 & 5.14 & 4 & 235 & 27.5 & 0.16 & 8.2 & 13.0 \\
\hline $3 / 28 / 2013$ & $19: 41: 45.0$ & 43.8873 & -113.7212 & 1.5 ML IE & 80.0 & 1.30 & 17 & 150 & 22.1 & 0.08 & 0.5 & 2.9 \\
\hline $3 / 29 / 2013$ & 05:29:50.6 & 43.8895 & -110.8193 & $0.2 \mathrm{Mc} \mathrm{IE}$ & 160.3 & 9.44 & 6 & 187 & 9.7 & 0.08 & 3.0 & 4.2 \\
\hline $3 / 29 / 2013$ & 11:09:38.6 & 42.6273 & -111.4382 & 1.6 ML IE & 157.8 & 4.96 & 6 & 230 & 31.6 & 0.02 & 1.3 & 9.6 \\
\hline 3/30/2013 & $07: 11: 51.8$ & 42.8953 & -111.2025 & $0.8 \mathrm{Mc}$ IE & 153.3 & 10.52 & 8 & 136 & 16.7 & 0.05 & 0.5 & 2.1 \\
\hline $3 / 30 / 2013$ & $08: 55: 15.3$ & 43.6730 & -110.8488 & $0.6 \mathrm{Mc} \mathrm{IE}$ & 156.0 & 3.93 & 4 & 212 & 14.9 & 0.05 & 5.7 & 11.9 \\
\hline $3 / 30 / 2013$ & $10: 18: 43.6$ & 44.2355 & -111.0772 & $0.8 \mathrm{Mc}$ IE & 151.6 & 4.56 & 4 & 239 & 9.8 & 0.11 & 4.7 & 14.8 \\
\hline $3 / 31 / 2013$ & $14: 32: 48.4$ & 44.7910 & -112.4782 & 1.9 Mc IE & 129.2 & 6.31 & 3 & 176 & 29.6 & 0.10 & 1.4 & 15.2 \\
\hline $3 / 31 / 2013$ & $22: 03: 54.5$ & 43.6517 & -111.0482 & $0.6 \mathrm{Mc} \mathrm{IE}$ & 139.9 & 18.22 & 4 & 338 & 2.3 & 0.10 & 14.9 & 1.5 \\
\hline $4 / 1 / 2013$ & $19: 52: 13.2$ & 43.3427 & -111.0895 & $0.5 \mathrm{Mc} \mathrm{IE}$ & 141.1 & 5.83 & 5 & 285 & 19.4 & 0.02 & 1.4 & 7.4 \\
\hline $4 / 3 / 2013$ & $09: 27: 23.8$ & 44.9788 & -113.1103 & $2.6 \mathrm{Mc} \mathrm{IE}$ & 150.1 & 2.07 & 8 & 282 & 119.8 & 0.24 & 12.9 & 13.9 \\
\hline $4 / 4 / 2013$ & 01:52:48.6 & 43.3117 & -110.8925 & $0.7 \mathrm{Mc} \mathrm{IE}$ & 157.4 & 5.69 & 7 & 310 & 6.5 & 0.12 & 1.2 & 1.4 \\
\hline $4 / 4 / 2013$ & 02:03:20.8 & 44.6028 & -112.0763 & 1.6 Mc IE & 120.1 & 5.00 & 4 & 133 & 34.8 & 0.15 & 1.2 & 17.8 \\
\hline $4 / 4 / 2013$ & $10: 26: 13.8$ & 43.7590 & -111.1490 & 1.1 Mc IE & 132.2 & 5.02 & 4 & 319 & 33.9 & 0.04 & 1.4 & 13.0 \\
\hline $4 / 5 / 2013$ & $17: 44: 05.4$ & 43.2248 & -110.8955 & 1.9 ML IE & 159.9 & 14.54 & 7 & 186 & 15.7 & 0.15 & 1.7 & 3.9 \\
\hline $4 / 5 / 2013$ & $19: 19: 34.0$ & 43.2308 & -110.9412 & $0.8 \mathrm{Mc} \mathrm{IE}$ & 156.2 & 8.86 & 7 & 163 & 16.3 & 0.09 & 1.1 & 2.1 \\
\hline $4 / 5 / 2013$ & $21: 11: 03.3$ & 43.4525 & -110.9278 & $0.9 \mathrm{Mc}$ IE & 151.4 & 18.68 & 4 & 282 & 4.6 & 0.00 & 1.4 & 1.7 \\
\hline $4 / 7 / 2013$ & 04:08:27.1 & 43.3000 & -110.8997 & 1.0 Mc IE & 157.2 & 19.09 & 6 & 311 & 21.5 & 0.06 & 1.4 & 2.1 \\
\hline $4 / 7 / 2013$ & 04:08:36.7 & 43.2672 & -110.8708 & $0.3 \mathrm{Mc} \mathrm{IE}$ & 160.4 & 5.09 & 4 & 315 & 25.6 & 0.27 & 3.4 & 19.1 \\
\hline $4 / 7 / 2013$ & $04: 27: 32.4$ & 44.2465 & -111.2555 & 1.1 Mc IE & 139.4 & 4.89 & 4 & 268 & 48.1 & 0.28 & 2.2 & 26.6 \\
\hline $4 / 8 / 2013$ & $08: 56: 20.3$ & 43.6473 & -110.8507 & $0.5 \mathrm{Mc} \mathrm{IE}$ & 155.8 & 5.12 & 4 & 275 & 14.3 & 0.15 & 4.3 & 16.8 \\
\hline $4 / 8 / 2013$ & $22: 47: 36.8$ & 43.5518 & -111.1638 & $1.5 \mathrm{Mc} \mathrm{IE}$ & 131.1 & 9.12 & 5 & 298 & 14.6 & 0.03 & 1.2 & 1.6 \\
\hline $4 / 9 / 2013$ & $15: 18: 41.6$ & 44.6362 & -113.8808 & 1.7 ML IE & 140.5 & 7.08 & 13 & 210 & 52.3 & 0.04 & 1.4 & 2.2 \\
\hline $4 / 11 / 2013$ & $13: 50: 13.9$ & 43.5473 & -111.1922 & $0.9 \mathrm{Mc} \mathrm{IE}$ & 128.9 & 4.95 & 5 & 286 & 16.7 & 0.03 & 2.7 & 12.2 \\
\hline $4 / 12 / 2013$ & $17: 25: 20.3$ & 43.5448 & -111.1818 & 1.1 Mc IE & 129.8 & 3.17 & 4 & 279 & 16.3 & 0.12 & 2.2 & 13.4 \\
\hline $4 / 14 / 2013$ & $17: 55: 01.9$ & 42.9000 & -111.2347 & 1.3 Mc IE & 150.8 & 4.82 & 5 & 143 & 15.8 & 0.03 & 1.4 & 12.6 \\
\hline $4 / 15 / 2013$ & 02:19:16.6 & 44.9245 & -111.8983 & $1.5 \mathrm{Mc} \mathrm{IE}$ & 158.4 & 5.00 & 4 & 258 & 28.4 & 0.29 & 10.6 & 18.8 \\
\hline $4 / 15 / 2013$ & $03: 11: 11.7$ & 43.8450 & -111.1520 & 1.2 Mc IE & 133.1 & 5.01 & 4 & 323 & 42.6 & 0.06 & 1.4 & 13.4 \\
\hline $4 / 15 / 2013$ & 07:07:26.6 & 43.5568 & -111.1722 & 1.7 ML IE & 130.4 & 11.04 & 7 & 283 & 14.8 & 0.06 & 1.0 & 1.9 \\
\hline $4 / 15 / 2013$ & $07: 31: 58.0$ & 43.6513 & -110.8497 & $0.7 \mathrm{Mc} \mathrm{IE}$ & 155.9 & 5.09 & 5 & 276 & 14.4 & 0.14 & 4.1 & 16.1 \\
\hline $4 / 15 / 2013$ & 09:01:01.5 & 43.6112 & -111.0208 & $0.5 \mathrm{Mc}$ IE & 142.2 & 10.19 & 4 & 194 & 3.0 & 0.06 & 13.3 & 1.5 \\
\hline $4 / 15 / 2013$ & $09: 51: 20.2$ & 43.6548 & -110.8460 & $0.8 \mathrm{Mc} \mathrm{IE}$ & 156.2 & 5.09 & 5 & 278 & 14.7 & 0.12 & 3.7 & 15.1 \\
\hline $4 / 15 / 2013$ & $10: 39: 49.9$ & 42.8193 & -111.2502 & 1.2 Mc IE & 155.0 & 17.77 & 5 & 198 & 13.6 & 0.04 & 1.2 & 3.4 \\
\hline $4 / 15 / 2013$ & $16: 58: 37.2$ & 43.2368 & -111.5535 & $0.7 \mathrm{ML}$ IE & 109.6 & 4.92 & 8 & 250 & 25.2 & 0.08 & 1.1 & 12.4 \\
\hline $4 / 16 / 2013$ & $21: 31: 04.2$ & 43.6153 & -111.0278 & 1.0 Mc IE & 141.6 & 17.92 & 4 & 208 & 2.5 & 0.02 & 12.6 & 1.4 \\
\hline
\end{tabular}


Table C-2. Continued.

\begin{tabular}{|c|c|c|c|c|c|c|c|c|c|c|c|c|}
\hline ORIGIN & TIME & LAT N & LONG W & MAG-TYP & DIST & $z$ & NO & GAP & DMIN & RMS & $\mathrm{ERH}$ & ERZ \\
\hline $4 / 17 / 2013$ & $21: 40: 10.1$ & 42.7083 & -111.6953 & 1.1 Mc IE & 137.1 & 5.05 & 4 & 321 & 49.1 & 0.26 & 2.6 & 25.2 \\
\hline $4 / 18 / 2013$ & $15: 49: 51.8$ & 44.3145 & -111.0755 & 1.1 Mc IE & 155.6 & 4.34 & 4 & 250 & 16.2 & 0.05 & 2.9 & 12.8 \\
\hline $4 / 19 / 2013$ & $10: 28: 50.8$ & 44.7092 & -111.6468 & 1.1 Mc IE & 148.8 & 1.64 & 4 & 180 & 2.7 & 0.08 & 14.1 & 11.8 \\
\hline $4 / 20 / 2013$ & 08:01:53.4 & 43.6420 & -110.8918 & $0.8 \mathrm{Mc}$ IE & 152.5 & 15.27 & 6 & 266 & 10.9 & 0.07 & 9.6 & 7.1 \\
\hline $4 / 20 / 2013$ & $14: 46: 35.6$ & 43.6200 & -111.0325 & $0.8 \mathrm{Mc} \mathrm{IE}$ & 141.2 & 19.19 & 4 & 220 & 2.1 & 0.05 & 13.2 & 1.4 \\
\hline $4 / 22 / 2013$ & $04: 49: 52.7$ & 44.4383 & -111.2173 & $0.9 \mathrm{Mc}$ IE & 153.0 & 5.60 & 7 & 319 & 27.7 & 0.13 & 4.8 & 14.9 \\
\hline $4 / 22 / 2013$ & 09:51:05.3 & 43.2662 & -111.2000 & $0.9 \mathrm{Mc}$ IE & 135.0 & 4.87 & 4 & 342 & 30.2 & 0.30 & 5.4 & 27.6 \\
\hline $4 / 22 / 2013$ & 09:54:17.1 & 44.8463 & -112.9845 & 1.2 Mc IE & 134.1 & 2.50 & 4 & 250 & 10.9 & 0.56 & 19.8 & 33.0 \\
\hline $4 / 22 / 2013$ & $17: 12: 37.6$ & 42.6347 & -112.0073 & $2.4 \mathrm{ML} \mathrm{IE}$ & 129.4 & 7.08 & 18 & 116 & 39.6 & 0.05 & 0.3 & 1.8 \\
\hline $4 / 23 / 2013$ & 01:05:03.3 & 42.6077 & -112.0482 & $0.9 \mathrm{Mc} \mathrm{IE}$ & 130.4 & 4.90 & 3 & 178 & 39.3 & 0.03 & 3.5 & 12.0 \\
\hline $4 / 23 / 2013$ & 08:59:11.2 & 43.1540 & -111.9180 & 1.3 Mc IE & 89.2 & 4.96 & 5 & 310 & 45.9 & 0.02 & 1.5 & 12.4 \\
\hline $4 / 24 / 2013$ & $06: 18: 45.2$ & 44.6953 & -111.8953 & $1.5 \mathrm{Mc} \mathrm{IE}$ & 136.2 & 5.24 & 4 & 289 & 18.6 & 0.19 & 11.6 & 13.4 \\
\hline $4 / 25 / 2013$ & $04: 41: 49.2$ & 43.6150 & -111.0840 & $0.4 \mathrm{Mc}$ IE & 137.1 & 8.98 & 4 & 290 & 5.3 & 0.01 & 1.7 & 1.1 \\
\hline $4 / 25 / 2013$ & $06: 40: 41.3$ & 44.1945 & -113.1908 & $0.8 \mathrm{Mc} \mathrm{IE}$ & 68.8 & 2.51 & 4 & 217 & 21.5 & 0.15 & 1.2 & 17.2 \\
\hline $4 / 26 / 2013$ & $11: 18: 41.0$ & 43.6303 & -110.8693 & 1.1 Mc IE & 154.3 & 4.37 & 5 & 187 & 16.9 & 0.15 & 3.1 & 15.3 \\
\hline $4 / 27 / 2013$ & $06: 49: 19.9$ & 44.0203 & -111.0752 & $0.8 \mathrm{Mc} \mathrm{IE}$ & 143.3 & 4.88 & 3 & 327 & 17.5 & 0.05 & 3.3 & 12.8 \\
\hline $4 / 27 / 2013$ & $10: 24: 23.0$ & 44.4902 & -112.8685 & 1.8 Mc IE & 93.7 & 7.94 & 4 & 186 & 39.4 & 0.01 & 1.2 & 12.3 \\
\hline $4 / 27 / 2013$ & $11: 44: 09.0$ & 43.4655 & -110.8507 & $0.8 \mathrm{Mc} \mathrm{IE}$ & 157.4 & 4.77 & 5 & 217 & 8.5 & 0.05 & 6.5 & 11.2 \\
\hline $4 / 27 / 2013$ & $22: 41: 28.9$ & 44.6117 & -113.0845 & $1.9 \mathrm{Mc} \mathrm{IE}$ & 109.7 & 7.38 & 5 & 179 & 30.4 & 0.12 & 1.3 & 15.7 \\
\hline $4 / 28 / 2013$ & $07: 33: 48.6$ & 44.5772 & -112.8022 & $2.3 \mathrm{Mc} \mathrm{IE}$ & 103.2 & 5.01 & 8 & 151 & 28.1 & 0.12 & 1.1 & 16.1 \\
\hline $4 / 29 / 2013$ & 07:06:59.7 & 43.1898 & -110.9938 & 1.1 Mc IE & 153.6 & 7.03 & 8 & 324 & 22.4 & 0.07 & 1.2 & 4.0 \\
\hline $5 / 1 / 2013$ & $02: 33: 52.4$ & 44.1930 & -112.4653 & $0.0 \mathrm{Mc} \mathrm{IE}$ & 65.6 & 5.18 & 4 & 182 & 20.3 & 0.16 & 8.9 & 15.7 \\
\hline $5 / 1 / 2013$ & $13: 42: 53.2$ & 44.6892 & -111.7452 & $1.5 \mathrm{Mc} \mathrm{IE}$ & 142.3 & 5.35 & 4 & 350 & 109.0 & 0.18 & 15.7 & 11.2 \\
\hline $5 / 1 / 2013$ & $21: 45: 04.3$ & 42.9722 & -111.1925 & 1.4 Mc IE & 149.4 & 4.64 & 4 & 231 & 24.2 & 0.07 & 2.9 & 13.5 \\
\hline $5 / 3 / 2013$ & $00: 30: 11.9$ & 44.2147 & -114.0680 & 2.1 Mc IE & 120.8 & 4.90 & 4 & 281 & 58.7 & 0.07 & 7.1 & 11.8 \\
\hline $5 / 3 / 2013$ & $06: 05: 30.4$ & 43.5845 & -111.1238 & $0.7 \mathrm{Mc} \mathrm{IE}$ & 134.1 & 10.52 & 8 & 274 & 9.8 & 0.06 & 0.9 & 1.4 \\
\hline $5 / 5 / 2013$ & $06: 00: 33.8$ & 42.8160 & -111.2452 & $0.8 \mathrm{Mc}$ IE & 155.6 & 5.11 & 4 & 272 & 13.1 & 0.02 & 3.6 & 12.1 \\
\hline $5 / 5 / 2013$ & $13: 23: 12.0$ & 43.3400 & -110.8750 & 1.2 Mc IE & 158.1 & 10.38 & 7 & 303 & 3.1 & 0.08 & 0.9 & 0.8 \\
\hline $5 / 5 / 2013$ & $14: 21: 43.1$ & 43.3625 & -110.8688 & 1.1 ML IE & 158.0 & 18.40 & 6 & 298 & 15.7 & 0.12 & 1.5 & 1.2 \\
\hline $5 / 6 / 2013$ & $03: 13: 43.3$ & 42.6248 & -111.9928 & 4.0 ML IE & 130.9 & 9.27 & 19 & 115 & 41.2 & 0.08 & 0.3 & 1.4 \\
\hline $5 / 6 / 2013$ & $03: 20: 13.3$ & 43.4957 & -110.8615 & $0.8 \mathrm{Mc} \mathrm{IE}$ & 156.1 & 4.96 & 6 & 216 & 7.2 & 0.05 & 6.6 & 11.1 \\
\hline $5 / 6 / 2013$ & $03: 20: 57.5$ & 42.6245 & -111.9918 & 3.5 ML NE & 131.0 & 2.23 & 15 & 122 & 41.3 & 0.07 & 0.4 & 13.7 \\
\hline $5 / 6 / 2013$ & $03: 27: 52.4$ & 42.6305 & -111.9903 & $2.0 \mathrm{Mc} \mathrm{IE}$ & 130.4 & 7.70 & 9 & 121 & 40.9 & 0.09 & 0.5 & 1.4 \\
\hline $5 / 6 / 2013$ & 03:31:59.7 & 42.6315 & -111.9842 & 1.6 ML IE & 130.6 & 2.55 & 6 & 121 & 41.3 & 0.05 & 0.6 & 13.0 \\
\hline $5 / 6 / 2013$ & $03: 48: 41.8$ & 42.6343 & -112.0107 & 1.6 ML IE & 129.3 & 5.53 & 7 & 123 & 39.4 & 0.14 & 0.7 & 2.2 \\
\hline $5 / 6 / 2013$ & 03:59:27.0 & 42.6977 & -111.9738 & $0.9 \mathrm{Mc} \mathrm{IE}$ & 124.7 & 2.93 & 4 & 218 & 37.7 & 0.07 & 4.1 & 14.0 \\
\hline $5 / 6 / 2013$ & $06: 18: 46.1$ & 42.6373 & -112.0120 & $2.5 \mathrm{ML} \mathrm{IE}$ & 128.9 & 7.36 & 15 & 117 & 39.1 & 0.06 & 0.3 & 1.8 \\
\hline $5 / 6 / 2013$ & $06: 23: 24.2$ & 42.6343 & -111.9897 & 1.8 ML IE & 130.1 & 5.08 & 8 & 121 & 40.7 & 0.07 & 0.5 & 2.4 \\
\hline $5 / 6 / 2013$ & $07: 13: 20.4$ & 43.1490 & -111.4982 & 1.2 Mc IE & 118.0 & 2.14 & 6 & 259 & 14.9 & 0.03 & 2.4 & 12.7 \\
\hline $5 / 6 / 2013$ & $11: 07: 34.0$ & 42.6342 & -111.9993 & $1.5 \mathrm{Mc} \mathrm{IE}$ & 129.7 & 7.94 & 6 & 172 & 40.1 & 0.07 & 0.9 & 2.7 \\
\hline $5 / 6 / 2013$ & $11: 32: 37.8$ & 42.5702 & -111.9232 & $2.0 \mathrm{Mc} \mathrm{IE}$ & 139.0 & 14.54 & 7 & 201 & 62.6 & 0.10 & 5.0 & 11.3 \\
\hline $5 / 6 / 2013$ & $12: 31: 27.3$ & 44.4497 & -112.3508 & $1.9 \mathrm{Mc} \mathrm{IE}$ & 95.5 & 5.40 & 4 & 134 & 16.3 & 0.23 & 2.7 & 5.7 \\
\hline $5 / 6 / 2013$ & $13: 19: 47.1$ & 42.6243 & -112.0227 & $1.5 \mathrm{Mc} \mathrm{IE}$ & 129.8 & 9.59 & 11 & 176 & 39.4 & 0.20 & 0.9 & 1.7 \\
\hline $5 / 6 / 2013$ & $14: 12: 28.9$ & 44.5720 & -112.7470 & $2.8 \mathrm{ML}$ US & 102.6 & 5.99 & 12 & 126 & 28.1 & 0.06 & 0.4 & 13.0 \\
\hline $5 / 6 / 2013$ & $14: 16: 22.9$ & 44.4515 & -112.8602 & 1.1 Mc IE & 89.4 & 0.02 & 4 & 185 & 40.3 & 0.26 & 2.8 & 5.8 \\
\hline $5 / 6 / 2013$ & $14: 17: 26.5$ & 44.4903 & -112.7232 & 2.4 ML IE & 93.6 & 6.96 & 10 & 252 & 24.9 & 0.36 & 2.6 & 18.5 \\
\hline $5 / 6 / 2013$ & $14: 21: 45.5$ & 44.4567 & -112.8432 & 1.2 Mc IE & 89.9 & 7.90 & 3 & 185 & 38.8 & 0.03 & 1.3 & 12.6 \\
\hline $5 / 6 / 2013$ & $15: 51: 27.2$ & 42.6040 & -112.0285 & $1.5 \mathrm{Mc} \mathrm{IE}$ & 131.6 & 4.78 & 4 & 180 & 40.7 & 0.03 & 5.7 & 10.5 \\
\hline $5 / 6 / 2013$ & $16: 24: 49.5$ & 44.5118 & -113.0435 & 2.2 ML IE & 98.1 & 7.08 & 14 & 147 & 21.8 & 0.29 & 1.1 & 12.4 \\
\hline $5 / 6 / 2013$ & $19: 38: 50.5$ & 44.4307 & -112.8503 & $1.9 \mathrm{Mc}$ IE & 87.0 & 0.08 & 3 & 191 & 40.5 & 0.21 & 2.2 & 5.3 \\
\hline $5 / 6 / 2013$ & $22: 29: 08.0$ & 44.5520 & -112.7580 & 1.9 Mc IE & 100.4 & 5.95 & 13 & 128 & 29.2 & 0.39 & 1.7 & 34.6 \\
\hline
\end{tabular}


Table C-2. Continued.

\begin{tabular}{|c|c|c|c|c|c|c|c|c|c|c|c|c|}
\hline ORIGIN & TIME & LAT N & LONG W & MAG-TYP & DIST & Z & NO & GAP & DMIN & RMS & $\mathrm{ERH}$ & ERZ \\
\hline $5 / 6 / 2013$ & $22: 35: 42.9$ & 44.4517 & -112.8722 & 1.3 Mc IE & 89.5 & 0.04 & 3 & 183 & 41.1 & 0.09 & 1.6 & 3.6 \\
\hline $5 / 6 / 2013$ & $23: 20: 38.6$ & 44.5617 & -112.7508 & $2.0 \mathrm{Mc} \mathrm{IE}$ & 101.5 & 6.12 & 7 & 127 & 28.5 & 0.13 & 1.0 & 16.1 \\
\hline $5 / 7 / 2013$ & $09: 16: 02.8$ & 44.4243 & -112.8745 & $1.9 \mathrm{Mc} \mathrm{IE}$ & 86.5 & 40.19 & 8 & 144 & 11.8 & 0.12 & 1.9 & 4.2 \\
\hline $5 / 7 / 2013$ & 09:18:43.5 & 44.6125 & -112.9265 & 1.9 Mc IE & 107.7 & 3.60 & 8 & 184 & 31.5 & 0.24 & 7.1 & 2.6 \\
\hline $5 / 7 / 2013$ & $09: 24: 56.3$ & 43.2818 & -111.0625 & 1.3 ML IE & 145.1 & 14.35 & 10 & 180 & 19.3 & 0.11 & 0.8 & 1.2 \\
\hline $5 / 7 / 2013$ & 09:46:09.5 & 44.5683 & -112.7465 & $2.8 \mathrm{ML} \mathrm{IE}$ & 102.2 & 6.95 & 18 & 126 & 29.9 & 0.22 & 0.8 & 19.3 \\
\hline $5 / 7 / 2013$ & $10: 50: 26.2$ & 44.5740 & -112.7557 & 2.1 ML IE & 102.8 & 6.81 & 12 & 127 & 29.1 & 0.25 & 1.3 & 4.7 \\
\hline $5 / 7 / 2013$ & $11: 30: 06.7$ & 44.4990 & -112.7923 & $1.9 \mathrm{Mc} \mathrm{IE}$ & 94.5 & 5.71 & 11 & 324 & 22.3 & 0.19 & 1.9 & 2.6 \\
\hline $5 / 7 / 2013$ & $11: 39: 03.3$ & 44.5947 & -112.6733 & $2.2 \mathrm{Mc} \mathrm{IE}$ & 105.5 & 18.37 & 9 & 173 & 85.5 & 0.07 & 0.9 & 13.9 \\
\hline $5 / 7 / 2013$ & $18: 11: 24.9$ & 42.6168 & -112.0298 & $2.0 \mathrm{Mc} \mathrm{IE}$ & 130.2 & 10.65 & 13 & 129 & 39.6 & 0.07 & 0.4 & 0.9 \\
\hline $5 / 8 / 2013$ & $02: 23: 14.8$ & 44.4592 & -112.8740 & 1.1 Mc IE & 90.3 & 5.00 & 3 & 181 & 40.9 & 0.23 & 2.9 & 8.5 \\
\hline $5 / 8 / 2013$ & $03: 47: 08.5$ & 42.6195 & -112.0183 & $2.0 \mathrm{ML} \mathrm{IE}$ & 130.4 & 6.40 & 12 & 127 & 40.1 & 0.08 & 0.3 & 2.3 \\
\hline $5 / 8 / 2013$ & $10: 07: 38.1$ & 44.1952 & -114.0190 & 1.4 Mc IE & 116.3 & 5.26 & 4 & 277 & 54.2 & 0.07 & 7.2 & 11.6 \\
\hline $5 / 8 / 2013$ & $10: 36: 11.6$ & 44.5012 & -113.6747 & 1.6 Mc IE & 118.6 & 6.24 & 5 & 256 & 66.1 & 0.01 & 7.5 & 10.0 \\
\hline $5 / 8 / 2013$ & $10: 38: 42.3$ & 44.4507 & -112.8743 & 1.6 Mc IE & 89.4 & 5.00 & 3 & 184 & 41.3 & 0.25 & 2.9 & 13.6 \\
\hline $5 / 8 / 2013$ & $11: 19: 31.1$ & 42.6298 & -112.0003 & $1.8 \mathrm{Mc} \mathrm{IE}$ & 130.1 & 5.00 & 3 & 173 & 40.4 & 0.02 & 1.6 & 12.1 \\
\hline $5 / 8 / 2013$ & $14: 43: 03.4$ & 42.6158 & -112.0225 & $0.9 \mathrm{Mc} \mathrm{IE}$ & 130.6 & 4.98 & 3 & 183 & 40.1 & 0.06 & 1.3 & 12.6 \\
\hline $5 / 8 / 2013$ & $18: 22: 36.4$ & 42.6037 & -112.0195 & $2.1 \mathrm{Mc} \mathrm{IE}$ & 131.9 & 17.13 & 5 & 157 & 64.7 & 0.06 & 0.7 & 13.5 \\
\hline $5 / 9 / 2013$ & 09:54:07.2 & 44.2017 & -112.5192 & 1.3 Mc IE & 64.9 & 5.38 & 3 & 173 & 22.4 & 0.06 & 7.4 & 13.1 \\
\hline $5 / 9 / 2013$ & $10: 57: 33.2$ & 44.6118 & -113.1187 & $1.7 \mathrm{Mc} \mathrm{IE}$ & 110.3 & 5.10 & 6 & 186 & 32.1 & 0.12 & 5.0 & 14.5 \\
\hline $5 / 9 / 2013$ & $15: 27: 37.5$ & 44.4240 & -112.8722 & 1.3 Mc IE & 86.4 & 2.80 & 3 & 191 & 42.4 & 0.02 & 6.3 & 10.2 \\
\hline $5 / 9 / 2013$ & $17: 32: 00.9$ & 43.7667 & -110.8632 & $0.6 \mathrm{Mc} \mathrm{IE}$ & 155.2 & 10.31 & 6 & 151 & 15.7 & 0.01 & 0.5 & 2.8 \\
\hline $5 / 9 / 2013$ & $18: 26: 54.1$ & 44.4037 & -112.5988 & 1.7 Mc IE & 85.1 & 0.01 & 4 & 339 & 28.5 & 0.30 & 14.6 & 8.3 \\
\hline $5 / 9 / 2013$ & $19: 51: 26.6$ & 44.5555 & -111.3800 & $0.8 \mathrm{Mc}$ IE & 150.8 & 5.03 & 5 & 350 & 43.5 & 0.36 & 14.2 & 29.5 \\
\hline $5 / 9 / 2013$ & $23: 23: 34.4$ & 44.5773 & -112.7975 & 1.9 Mc IE & 103.2 & 7.20 & 4 & 180 & 28.1 & 0.05 & 0.9 & 13.0 \\
\hline $5 / 10 / 2013$ & $01: 46: 33.8$ & 43.5867 & -110.8295 & $0.3 \mathrm{ML} \mathrm{IE}$ & 157.8 & 5.10 & 6 & 255 & 14.5 & 0.05 & 3.5 & 12.7 \\
\hline $5 / 10 / 2013$ & $04: 56: 42.2$ & 44.5878 & -112.8125 & $2.3 \mathrm{Mc} \mathrm{IE}$ & 104.4 & 6.18 & 6 & 170 & 30.5 & 0.00 & 2.9 & 6.7 \\
\hline $5 / 10 / 2013$ & $06: 02: 28.6$ & 42.6123 & -111.9522 & $0.8 \mathrm{Mc} \mathrm{IE}$ & 133.8 & 5.09 & 5 & 323 & 71.9 & 0.25 & 14.1 & 16.1 \\
\hline $5 / 12 / 2013$ & 04:39:04.7 & 42.6325 & -111.9853 & 1.8 Mc IE & 130.5 & 2.28 & 4 & 233 & 41.1 & 0.03 & 3.7 & 12.8 \\
\hline $5 / 12 / 2013$ & $10: 34: 31.9$ & 43.5133 & -110.8547 & $0.9 \mathrm{Mc}$ IE & 156.4 & 6.21 & 4 & 224 & 8.2 & 0.16 & 9.1 & 14.9 \\
\hline $5 / 12 / 2013$ & $17: 56: 28.8$ & 43.2090 & -110.9688 & 1.6 ML IE & 154.8 & 21.44 & 9 & 162 & 31.3 & 0.11 & 1.0 & 2.6 \\
\hline $5 / 14 / 2013$ & $21: 34: 42.2$ & 44.0635 & -114.6402 & $2.0 \mathrm{Mc} \mathrm{IE}$ & 156.2 & 8.34 & 4 & 257 & 58.8 & 0.08 & 2.2 & 3.3 \\
\hline $5 / 19 / 2013$ & $09: 22: 47.7$ & 42.7820 & -111.2703 & $0.7 \mathrm{Mc} \mathrm{IE}$ & 156.3 & 5.10 & 4 & 290 & 14.0 & 0.04 & 3.5 & 12.5 \\
\hline $5 / 20 / 2013$ & $22: 21: 32.4$ & 43.0028 & -111.6627 & 1.7 Mc IE & 115.9 & 5.00 & 9 & 187 & 24.5 & 0.08 & 0.5 & 10.4 \\
\hline $5 / 21 / 2013$ & 08:10:38.9 & 43.7855 & -111.0100 & $0.5 \mathrm{Mc} \mathrm{IE}$ & 143.6 & 7.55 & 4 & 199 & 13.6 & 0.00 & 11.7 & 4.4 \\
\hline $5 / 21 / 2013$ & 08:34:18.4 & 44.5678 & -112.7520 & 3.5 ML IE & 102.1 & 5.86 & 19 & 127 & 28.5 & 0.14 & 0.4 & 14.4 \\
\hline $5 / 21 / 2013$ & $08: 44: 03.0$ & 44.5188 & -112.7945 & $2.1 \mathrm{Mc} \mathrm{IE}$ & 96.7 & 2.01 & 9 & 323 & 50.5 & 0.13 & 5.7 & 11.9 \\
\hline $5 / 21 / 2013$ & $09: 55: 10.2$ & 44.5667 & -112.7732 & $2.0 \mathrm{Mc} \mathrm{IE}$ & 102.0 & 5.02 & 4 & 131 & 29.6 & 0.42 & 4.7 & 32.1 \\
\hline $5 / 21 / 2013$ & $10: 01: 01.4$ & 44.5057 & -112.7337 & $2.6 \mathrm{Mc} \mathrm{IE}$ & 95.3 & 0.01 & 20 & 133 & 25.6 & 0.61 & 1.1 & 2.2 \\
\hline $5 / 21 / 2013$ & $10: 06: 40.9$ & 44.5630 & -112.8552 & 1.7 Mc IE & 101.7 & 6.94 & 8 & 169 & 29.4 & 0.15 & 1.5 & 17.7 \\
\hline $5 / 21 / 2013$ & $10: 49: 16.6$ & 44.5867 & -112.7185 & $2.5 \mathrm{Mc} \mathrm{IE}$ & 104.3 & 13.28 & 13 & 138 & 25.7 & 0.04 & 0.9 & 1.2 \\
\hline $5 / 21 / 2013$ & $11: 02: 25.6$ & 44.5692 & -112.7735 & 1.8 Mc IE & 102.3 & 7.00 & 7 & 184 & 29.3 & 0.09 & 0.9 & 14.4 \\
\hline $5 / 21 / 2013$ & $11: 08: 34.4$ & 44.5865 & -113.0467 & $1.8 \mathrm{Mc} \mathrm{IE}$ & 106.3 & 4.97 & 4 & 206 & 31.0 & 0.27 & 7.8 & 20.5 \\
\hline $5 / 21 / 2013$ & $11: 14: 14.6$ & 44.5723 & -112.7303 & 1.4 Mc IE & 102.7 & 5.00 & 4 & 130 & 26.8 & 0.18 & 1.1 & 19.3 \\
\hline $5 / 21 / 2013$ & $11: 20: 37.0$ & 44.5765 & -112.7445 & $3.2 \mathrm{Mc} M B$ & 103.1 & 10.61 & 19 & 125 & 27.9 & 0.12 & 0.5 & 2.2 \\
\hline $5 / 21 / 2013$ & $11: 40: 18.4$ & 44.5688 & -112.7215 & 1.4 Mc IE & 102.3 & 5.00 & 3 & 131 & 26.1 & 0.16 & 1.5 & 6.8 \\
\hline $5 / 21 / 2013$ & $11: 56: 49.6$ & 44.5915 & -112.8427 & $1.9 \mathrm{Mc} \mathrm{IE}$ & 104.8 & 5.84 & 4 & 253 & 35.6 & 0.48 & 5.8 & 42.1 \\
\hline $5 / 21 / 2013$ & $12: 17: 26.7$ & 44.5393 & -112.7758 & 1.7 Mc IE & 98.9 & 5.52 & 4 & 313 & 72.9 & 0.09 & 6.6 & 12.4 \\
\hline $5 / 21 / 2013$ & $12: 34: 12.3$ & 44.5768 & -112.7388 & 1.7 Mc IE & 103.2 & 5.01 & 4 & 132 & 27.4 & 0.13 & 1.1 & 16.7 \\
\hline $5 / 21 / 2013$ & $12: 52: 36.4$ & 43.5287 & -111.0135 & $0.5 \mathrm{Mc}$ IE & 143.5 & 2.35 & 6 & 211 & 6.6 & 0.10 & 0.8 & 12.1 \\
\hline $5 / 21 / 2013$ & $13: 13: 55.3$ & 44.5683 & -112.7420 & $2.3 \mathrm{Mc}$ IE & 102.2 & 6.16 & 18 & 125 & 27.8 & 0.07 & 0.4 & 11.4 \\
\hline
\end{tabular}


Table C-2. Continued.

\begin{tabular}{|c|c|c|c|c|c|c|c|c|c|c|c|c|}
\hline ORIGIN & TIME & LAT N & LONG W & MAG-TYP & DIST & $z$ & NO & GAP & DMIN & RMS & $\mathrm{ERH}$ & ERZ \\
\hline $5 / 21 / 2013$ & $13: 33: 21.9$ & 44.5777 & -112.7445 & $1.5 \mathrm{Mc} \mathrm{IE}$ & 103.2 & 4.07 & 5 & 134 & 27.9 & 0.09 & 4.6 & 11.2 \\
\hline $5 / 21 / 2013$ & $14: 00: 41.6$ & 44.4353 & -112.6305 & 1.6 Mc IE & 88.2 & 1.79 & 6 & 168 & 25.7 & 0.00 & 2.3 & 2.4 \\
\hline $5 / 21 / 2013$ & $15: 00: 15.8$ & 44.5523 & -112.7722 & $1.9 \mathrm{Mc} \mathrm{IE}$ & 100.4 & 6.08 & 6 & 148 & 30.4 & 0.02 & 0.9 & 12.7 \\
\hline $5 / 21 / 2013$ & $15: 23: 33.2$ & 44.5625 & -112.7815 & $2.0 \mathrm{Mc} \mathrm{IE}$ & 101.5 & 4.86 & 7 & 198 & 30.0 & 0.10 & 4.6 & 11.9 \\
\hline $5 / 21 / 2013$ & 20:09:31.3 & 44.5160 & -111.8567 & 1.6 Mc IE & 121.6 & 4.73 & 4 & 338 & 64.8 & 0.13 & 7.0 & 14.8 \\
\hline $5 / 21 / 2013$ & $23: 39: 34.0$ & 44.5737 & -112.8238 & $1.9 \mathrm{Mc} \mathrm{IE}$ & 102.8 & 3.81 & 5 & 201 & 28.3 & 0.01 & 2.7 & 2.1 \\
\hline $5 / 22 / 2013$ & 08:33:00.2 & 44.5667 & -112.7420 & 2.7 ML IE & 102.0 & 7.52 & 17 & 125 & 27.8 & 0.08 & 0.4 & 6.4 \\
\hline $5 / 22 / 2013$ & 08:37:29.9 & 44.5688 & -112.7410 & 3.0 Mc MB & 102.3 & 9.92 & 17 & 125 & 27.7 & 0.06 & 0.4 & 3.0 \\
\hline $5 / 22 / 2013$ & 09:20:09.1 & 44.4842 & -112.7515 & $2.5 \mathrm{Mc} \mathrm{IE}$ & 92.8 & 0.03 & 10 & 166 & 22.9 & 0.18 & 1.3 & 3.1 \\
\hline $5 / 22 / 2013$ & 09:29:30.2 & 44.5755 & -112.8077 & 1.9 Mc IE & 103.0 & 7.11 & 6 & 204 & 28.2 & 0.05 & 2.3 & 13.3 \\
\hline $5 / 22 / 2013$ & $09: 32: 17.2$ & 44.5677 & -113.7840 & $2.7 \mathrm{Mc} \mathrm{IE}$ & 129.8 & 0.04 & 4 & 295 & 72.1 & 0.48 & 16.9 & 13.0 \\
\hline $5 / 22 / 2013$ & $09: 45: 60.0$ & 44.5670 & -112.7447 & $2.0 \mathrm{Mc} \mathrm{IE}$ & 102.1 & 2.44 & 4 & 134 & 28.0 & 0.00 & 0.8 & 2.7 \\
\hline $5 / 22 / 2013$ & 09:49:36.6 & 44.5703 & -112.7655 & $1.9 \mathrm{Mc} \mathrm{IE}$ & 102.4 & 4.88 & 6 & 140 & 29.3 & 0.00 & 0.6 & 1.8 \\
\hline $5 / 22 / 2013$ & $10: 49: 27.4$ & 44.5715 & -112.7423 & 1.8 Mc IE & 102.6 & 8.31 & 5 & 133 & 27.7 & 0.05 & 1.0 & 11.1 \\
\hline $5 / 22 / 2013$ & $11: 23: 00.0$ & 44.5692 & -112.7388 & 1.8 Mc IE & 102.3 & 4.99 & 3 & 132 & 27.5 & 0.02 & 0.8 & 10.1 \\
\hline $5 / 22 / 2013$ & $13: 17: 21.0$ & 44.5665 & -112.7387 & 1.5 Mc IE & 102.0 & 2.09 & 3 & 132 & 27.5 & 0.06 & 1.0 & 12.1 \\
\hline $5 / 22 / 2013$ & $15: 57: 54.5$ & 44.3418 & -113.9172 & 1.7 Mc IE & 119.1 & 7.15 & 4 & 212 & 59.1 & 0.11 & 1.7 & 15.5 \\
\hline $5 / 22 / 2013$ & $16: 12: 34.5$ & 44.6185 & -112.9715 & 1.9 Mc IE & 108.8 & 3.18 & 3 & 204 & 32.2 & 0.07 & 10.4 & 1.8 \\
\hline $5 / 22 / 2013$ & $17: 18: 48.5$ & 44.2768 & -113.4137 & $2.0 \mathrm{Mc} \mathrm{IE}$ & 86.2 & 9.10 & 4 & 303 & 75.9 & 0.00 & 3.1 & 1.8 \\
\hline $5 / 22 / 2013$ & $20: 02: 41.1$ & 42.5205 & -111.7172 & 1.3 Mc IE & 152.7 & 5.14 & 4 & 177 & 45.2 & 0.19 & 5.5 & 19.5 \\
\hline $5 / 23 / 2013$ & $05: 51: 48.0$ & 44.2360 & -113.0540 & 1.1 Mc IE & 68.7 & 4.78 & 4 & 321 & 65.9 & 0.15 & 9.4 & 9.1 \\
\hline $5 / 23 / 2013$ & $06: 04: 57.2$ & 44.5720 & -112.7575 & 1.9 Mc IE & 102.6 & 2.57 & 6 & 137 & 29.3 & 0.04 & 2.0 & 2.6 \\
\hline $5 / 23 / 2013$ & $06: 16: 56.8$ & 44.5175 & -112.7175 & $2.1 \mathrm{Mc} \mathrm{IE}$ & 96.7 & 5.86 & 6 & 210 & 37.4 & 0.05 & 2.0 & 13.1 \\
\hline $5 / 23 / 2013$ & 07:38:06.1 & 44.5920 & -112.7198 & $0.0 \mathrm{Mc} \mathrm{IE}$ & 104.9 & 4.73 & 4 & 163 & 25.9 & 0.00 & 4.4 & 6.7 \\
\hline $5 / 23 / 2013$ & 08:02:22.6 & 44.5593 & -112.7747 & $2.0 \mathrm{Mc} \mathrm{IE}$ & 101.2 & 6.63 & 6 & 182 & 28.8 & 0.10 & 1.6 & 13.8 \\
\hline $5 / 23 / 2013$ & 08:06:47.0 & 44.5588 & -112.6720 & 1.3 Mc IE & 101.5 & 2.97 & 3 & 141 & 22.4 & 0.02 & 1.2 & 10.8 \\
\hline $5 / 23 / 2013$ & $11: 45: 58.1$ & 44.4838 & -112.8173 & 1.5 Mc IE & 92.8 & 6.95 & 5 & 190 & 19.8 & 0.01 & 8.9 & 12.5 \\
\hline $5 / 23 / 2013$ & $11: 57: 21.4$ & 44.5007 & -112.7703 & $2.3 \mathrm{Mc} \mathrm{IE}$ & 94.7 & 5.00 & 6 & 135 & 91.3 & 0.63 & 2.8 & 13.3 \\
\hline $5 / 23 / 2013$ & $12: 08: 52.1$ & 44.6837 & -112.6318 & $2.1 \mathrm{Mc} \mathrm{IE}$ & 115.6 & 7.76 & 5 & 163 & 21.4 & 0.01 & 0.7 & 9.7 \\
\hline $5 / 23 / 2013$ & $12: 48: 20.3$ & 44.3872 & -114.0603 & $2.3 \mathrm{Mc} \mathrm{IE}$ & 131.2 & 2.87 & 5 & 225 & 95.7 & 0.02 & 3.5 & 8.9 \\
\hline $5 / 23 / 2013$ & $17: 30: 15.3$ & 44.5692 & -112.7348 & 3.0 ML MB & 102.3 & 10.95 & 18 & 123 & 27.2 & 0.11 & 0.4 & 2.4 \\
\hline $5 / 23 / 2013$ & $17: 31: 22.1$ & 44.5150 & -112.7715 & 3.4 ML MB & 96.2 & 6.05 & 15 & 256 & 24.7 & 0.13 & 1.2 & 0.6 \\
\hline $5 / 23 / 2013$ & $17: 34: 22.1$ & 44.5255 & -112.8533 & $2.2 \mathrm{Mc} \mathrm{IE}$ & 97.6 & 7.54 & 7 & 331 & 22.9 & 0.14 & 2.5 & 15.2 \\
\hline $5 / 23 / 2013$ & $17: 45: 37.1$ & 44.6022 & -113.1503 & $1.5 \mathrm{Mc} \mathrm{IE}$ & 109.9 & 5.01 & 4 & 227 & 34.6 & 0.22 & 9.7 & 7.1 \\
\hline $5 / 23 / 2013$ & $18: 40: 41.7$ & 44.5607 & -112.7342 & $1.5 \mathrm{Mc} \mathrm{IE}$ & 101.4 & 3.09 & 3 & 131 & 27.2 & 0.08 & 1.5 & 11.8 \\
\hline $5 / 23 / 2013$ & 21:31:54.1 & 44.5615 & -112.7387 & 1.6 Mc IE & 101.5 & 5.95 & 3 & 131 & 27.6 & 0.05 & 1.4 & 13.2 \\
\hline $5 / 23 / 2013$ & $23: 49: 14.4$ & 44.5655 & -112.7378 & 1.4 Mc IE & 101.9 & 5.01 & 4 & 129 & 27.5 & 0.05 & 1.2 & 13.1 \\
\hline $5 / 24 / 2013$ & $20: 35: 13.9$ & 44.5835 & -112.9097 & 1.4 Mc IE & 104.3 & 17.23 & 3 & 184 & 27.6 & 0.04 & 12.4 & 1.6 \\
\hline $5 / 25 / 2013$ & $10: 27: 03.6$ & 42.6415 & -111.4473 & $0.9 \mathrm{Mc} \mathrm{IE}$ & 156.1 & 3.75 & 6 & 313 & 31.6 & 0.03 & 1.3 & 12.6 \\
\hline $5 / 25 / 2013$ & $13: 52: 40.0$ & 44.5822 & -112.8110 & 1.6 Mc IE & 103.7 & 5.28 & 4 & 204 & 27.4 & 0.11 & 3.3 & 4.0 \\
\hline $5 / 25 / 2013$ & $16: 53: 05.6$ & 44.5858 & -112.7278 & 1.4 Mc IE & 104.2 & 5.00 & 4 & 123 & 26.5 & 0.18 & 1.3 & 19.3 \\
\hline $5 / 26 / 2013$ & $05: 34: 45.5$ & 44.5657 & -112.8045 & 1.6 Mc IE & 101.9 & 4.99 & 4 & 223 & 29.3 & 0.04 & 4.4 & 11.6 \\
\hline $5 / 26 / 2013$ & $06: 49: 48.7$ & 44.5570 & -112.7247 & 1.3 Mc IE & 101.0 & 5.00 & 5 & 134 & 26.5 & 0.12 & 1.2 & 16.1 \\
\hline $5 / 26 / 2013$ & 07:36:01.4 & 44.5728 & -112.6652 & 1.2 Mc IE & 103.1 & 6.10 & 4 & 143 & 21.6 & 0.10 & 1.4 & 15.1 \\
\hline $5 / 26 / 2013$ & $12: 46: 21.2$ & 42.8358 & -111.2188 & 1.0 ML IE & 156.0 & 12.98 & 5 & 205 & 12.5 & 0.01 & 1.5 & 3.4 \\
\hline $5 / 26 / 2013$ & $13: 46: 07.6$ & 44.5822 & -112.7480 & 1.6 Mc IE & 103.8 & 6.05 & 4 & 122 & 28.1 & 0.05 & 1.4 & 13.3 \\
\hline $5 / 26 / 2013$ & $18: 11: 02.4$ & 43.6738 & -111.0962 & $0.4 \mathrm{Mc} \mathrm{IE}$ & 136.0 & 3.81 & 5 & 335 & 6.9 & 0.15 & 9.4 & 11.7 \\
\hline $5 / 26 / 2013$ & $22: 41: 08.0$ & 44.5690 & -112.7112 & 1.6 Mc IE & 102.4 & 5.11 & 5 & 205 & 30.8 & 0.04 & 4.2 & 11.0 \\
\hline $5 / 27 / 2013$ & $08: 22: 13.8$ & 42.8790 & -111.2178 & 1.1 Mc IE & 153.3 & 13.66 & 8 & 186 & 15.9 & 0.17 & 1.0 & 1.0 \\
\hline $5 / 27 / 2013$ & $19: 19: 29.1$ & 44.7823 & -113.0823 & 1.4 Mc IE & 128.2 & 4.97 & 4 & 183 & 19.1 & 0.13 & 9.1 & 7.5 \\
\hline $5 / 28 / 2013$ & $15: 57: 16.9$ & 42.6342 & -112.0298 & $2.0 \mathrm{Mc} \mathrm{IE}$ & 128.5 & 11.12 & 13 & 127 & 38.3 & 0.09 & 0.3 & 0.9 \\
\hline
\end{tabular}


Table C-2. Continued.

\begin{tabular}{|c|c|c|c|c|c|c|c|c|c|c|c|c|}
\hline ORIGIN & TIME & LAT N & LONG W & MAG-TYP & DIST & Z & NO & GAP & DMIN & RMS & ERH & ERZ \\
\hline $5 / 28 / 2013$ & $22: 38: 57.7$ & 43.5942 & -111.1150 & 1.0 Mc IE & 134.7 & 12.53 & 7 & 275 & 8.6 & 0.11 & 1.0 & 1.3 \\
\hline $5 / 29 / 2013$ & 07:53:17.8 & 43.3295 & -110.9212 & $0.8 \mathrm{Mc} \mathrm{IE}$ & 154.7 & 10.01 & 8 & 291 & 6.7 & 0.17 & 1.2 & 1.4 \\
\hline $5 / 29 / 2013$ & $09: 58: 43.1$ & 44.5935 & -112.4690 & $2.0 \mathrm{Mc} \mathrm{IE}$ & 107.9 & 15.52 & 6 & 158 & 5.9 & 0.01 & 1.5 & 1.4 \\
\hline $5 / 29 / 2013$ & $18: 16: 34.2$ & 43.7362 & -111.0412 & $0.7 \mathrm{Mc}$ IE & 140.7 & 2.27 & 8 & 211 & 11.0 & 0.10 & 0.7 & 12.5 \\
\hline $5 / 30 / 2013$ & $08: 22: 56.3$ & 43.2217 & -111.5180 & $0.9 \mathrm{Mc} \mathrm{IE}$ & 112.9 & 4.98 & 6 & 253 & 22.2 & 0.19 & 2.3 & 20.0 \\
\hline $5 / 31 / 2013$ & $03: 33: 24.8$ & 44.3435 & -113.3633 & $0.8 \mathrm{Mc} \mathrm{IE}$ & 90.1 & 12.01 & 6 & 289 & 4.9 & 0.00 & 3.0 & 1.8 \\
\hline $6 / 1 / 2013$ & $09: 25: 45.1$ & 44.5740 & -112.6995 & $0.0 \mathrm{Mc} \mathrm{IE}$ & 103.0 & 0.06 & 9 & 173 & 30.6 & 0.09 & 0.9 & 4.9 \\
\hline $6 / 1 / 2013$ & $16: 35: 55.1$ & 43.5965 & -111.0170 & $0.5 \mathrm{Mc} \mathrm{IE}$ & 142.6 & 13.22 & 4 & 196 & 4.7 & 0.06 & 13.4 & 1.6 \\
\hline $6 / 2 / 2013$ & $06: 12: 45.7$ & 43.8842 & -110.9818 & $0.3 \mathrm{Mc} \mathrm{IE}$ & 147.3 & 15.33 & 6 & 239 & 3.7 & 0.04 & 2.6 & 1.2 \\
\hline $6 / 3 / 2013$ & $07: 42: 12.8$ & 42.8297 & -111.2473 & $0.5 \mathrm{Mc} \mathrm{IE}$ & 154.5 & 12.21 & 5 & 191 & 14.0 & 0.01 & 2.6 & 3.0 \\
\hline $6 / 4 / 2013$ & $03: 55: 27.4$ & 44.0577 & -113.8593 & $2.0 \mathrm{Mc} \mathrm{IE}$ & 97.7 & 7.02 & 14 & 193 & 35.7 & 0.09 & 0.5 & 14.2 \\
\hline $6 / 4 / 2013$ & $22: 16: 15.6$ & 42.8738 & -111.4353 & 1.4 Mc IE & 139.3 & 0.02 & 7 & 255 & 7.2 & 0.18 & 6.3 & 1.7 \\
\hline $6 / 5 / 2013$ & $06: 36: 28.2$ & 43.6985 & -111.0468 & $0.9 \mathrm{Mc} \mathrm{IE}$ & 140.1 & 10.88 & 4 & 215 & 6.9 & 0.01 & 4.4 & 3.6 \\
\hline $6 / 5 / 2013$ & $10: 25: 06.4$ & 43.7358 & -111.0463 & $0.7 \mathrm{Mc} \mathrm{IE}$ & 140.3 & 2.35 & 6 & 214 & 11.0 & 0.07 & 1.5 & 11.4 \\
\hline $6 / 5 / 2013$ & $10: 27: 08.6$ & 43.7383 & -111.0428 & $0.7 \mathrm{Mc} \mathrm{IE}$ & 140.6 & 2.08 & 6 & 212 & 11.2 & 0.05 & 2.0 & 13.1 \\
\hline $6 / 5 / 2013$ & $10: 34: 50.4$ & 44.5967 & -112.7455 & 1.0 Mc IE & 105.4 & 4.89 & 5 & 107 & 26.9 & 0.09 & 4.4 & 11.0 \\
\hline $6 / 5 / 2013$ & $11: 35: 25.1$ & 43.6960 & -110.9602 & $0.7 \mathrm{Mc} \mathrm{IE}$ & 147.0 & 4.70 & 4 & 174 & 8.4 & 0.03 & 5.5 & 9.4 \\
\hline $6 / 5 / 2013$ & $12: 23: 27.5$ & 43.6912 & -111.0582 & 1.1 Mc IE & 139.1 & 8.93 & 5 & 357 & 6.4 & 0.02 & 11.6 & 0.8 \\
\hline $6 / 5 / 2013$ & $12: 25: 25.2$ & 43.7075 & -110.9778 & $0.7 \mathrm{Mc} \mathrm{IE}$ & 145.6 & 2.68 & 6 & 160 & 8.7 & 0.09 & 1.0 & 10.8 \\
\hline $6 / 5 / 2013$ & $12: 48: 12.5$ & 43.6808 & -110.9592 & $0.5 \mathrm{Mc} \mathrm{IE}$ & 147.1 & 4.68 & 5 & 175 & 7.2 & 0.05 & 5.5 & 10.1 \\
\hline $6 / 5 / 2013$ & $12: 51: 04.6$ & 43.6818 & -110.9723 & 1.1 Mc IE & 146.0 & 6.14 & 5 & 241 & 6.5 & 0.02 & 2.4 & 1.7 \\
\hline $6 / 5 / 2013$ & $12: 51: 49.7$ & 43.6888 & -111.0102 & $0.5 \mathrm{Mc} \mathrm{IE}$ & 143.0 & 8.64 & 7 & 179 & 5.8 & 0.19 & 2.7 & 2.3 \\
\hline $6 / 5 / 2013$ & $12: 59: 15.6$ & 43.6963 & -110.9958 & 1.1 Mc IE & 144.2 & 7.93 & 5 & 264 & 6.9 & 0.01 & 2.0 & 2.3 \\
\hline $6 / 5 / 2013$ & $13: 11: 11.9$ & 43.6833 & -111.0283 & $0.9 \mathrm{Mc} \mathrm{IE}$ & 141.5 & 9.51 & 6 & 198 & 5.0 & 0.07 & 2.8 & 1.2 \\
\hline $6 / 5 / 2013$ & $13: 41: 04.1$ & 43.6995 & -110.9900 & 1.0 Mc IE & 144.6 & 6.85 & 6 & 166 & 7.4 & 0.05 & 2.0 & 2.5 \\
\hline $6 / 5 / 2013$ & $14: 56: 59.9$ & 43.7122 & -111.0043 & $0.8 \mathrm{Mc} \mathrm{IE}$ & 143.5 & 6.74 & 6 & 275 & 8.4 & 0.04 & 1.0 & 1.6 \\
\hline $6 / 6 / 2013$ & $04: 26: 14.8$ & 44.5757 & -112.7472 & 1.8 Mc IE & 103.0 & 5.01 & 6 & 103 & 28.1 & 0.09 & 0.8 & 14.6 \\
\hline $6 / 6 / 2013$ & $04: 26: 15.0$ & 44.5425 & -112.7268 & $1.9 \mathrm{Mc} \mathrm{IE}$ & 99.4 & 5.83 & 4 & 192 & 27.0 & 0.02 & 1.3 & 12.7 \\
\hline $6 / 6 / 2013$ & $04: 55: 43.1$ & 43.2500 & -111.0073 & 1.2 Mc IE & 150.4 & 4.99 & 5 & 320 & 27.1 & 0.07 & 1.4 & 11.5 \\
\hline $6 / 6 / 2013$ & $22: 20: 56.3$ & 42.6070 & -111.9692 & 1.1 Mc IE & 133.6 & 4.99 & 4 & 212 & 65.7 & 0.02 & 1.3 & 12.3 \\
\hline $6 / 7 / 2013$ & $04: 02: 22.8$ & 42.7333 & -111.3185 & $0.9 \mathrm{Mc} \mathrm{IE}$ & 156.7 & 4.90 & 4 & 262 & 18.2 & 0.05 & 2.1 & 11.4 \\
\hline $6 / 7 / 2013$ & $14: 20: 00.7$ & 44.5652 & -112.7315 & $2.1 \mathrm{Mc} \mathrm{IE}$ & 101.9 & 5.03 & 8 & 113 & 27.0 & 0.06 & 0.5 & 13.2 \\
\hline $6 / 8 / 2013$ & $10: 03: 34.9$ & 42.7232 & -111.7808 & 2.1 ML IE & 131.4 & 5.22 & 15 & 88 & 37.8 & 0.08 & 0.5 & 5.4 \\
\hline $6 / 8 / 2013$ & $10: 10: 57.5$ & 42.9578 & -111.2010 & $0.0 \mathrm{Mc} \mathrm{IE}$ & 149.6 & 9.15 & 6 & 125 & 17.4 & 0.03 & 0.9 & 4.0 \\
\hline $6 / 8 / 2013$ & $10: 15: 23.1$ & 42.9422 & -111.2313 & $0.9 \mathrm{Mc} \mathrm{IE}$ & 148.5 & 2.49 & 5 & 167 & 16.8 & 0.08 & 1.2 & 13.8 \\
\hline $6 / 11 / 2013$ & $05: 42: 12.6$ & 44.4437 & -113.4073 & $1.5 \mathrm{Mc} \mathrm{IE}$ & 101.5 & 12.96 & 4 & 221 & 14.8 & 0.00 & 3.3 & 1.8 \\
\hline $6 / 13 / 2013$ & 08:00:26.4 & 43.5613 & -110.8070 & 1.2 Mc IE & 159.8 & 3.23 & 7 & 120 & 14.0 & 0.16 & 0.5 & 14.6 \\
\hline $6 / 13 / 2013$ & $13: 58: 29.9$ & 42.9655 & -111.3372 & $0.8 \mathrm{Mc} \mathrm{IE}$ & 139.8 & 9.06 & 6 & 206 & 7.5 & 0.03 & 1.7 & 3.3 \\
\hline $6 / 13 / 2013$ & $22: 19: 31.0$ & 44.7730 & -111.7610 & $1.9 \mathrm{Mc} \mathrm{IE}$ & 149.2 & 9.36 & 4 & 207 & 8.9 & 0.01 & 0.8 & 2.5 \\
\hline $6 / 14 / 2013$ & $13: 09: 38.4$ & 43.5032 & -110.9963 & 1.0 Mc IE & 145.2 & 9.82 & 7 & 208 & 15.2 & 0.06 & 0.6 & 2.5 \\
\hline $6 / 16 / 2013$ & $16: 39: 26.7$ & 43.3605 & -110.8330 & $0.7 \mathrm{Mc} \mathrm{IE}$ & 160.9 & 12.45 & 6 & 286 & 1.5 & 0.02 & 3.5 & 1.2 \\
\hline $6 / 17 / 2013$ & $02: 14: 49.8$ & 44.3257 & -113.9827 & 1.0 Mc IE & 122.1 & 7.45 & 6 & 215 & 46.1 & 0.07 & 0.8 & 13.8 \\
\hline $6 / 17 / 2013$ & $06: 06: 29.3$ & 44.3030 & -113.9678 & 1.6 Mc IE & 119.6 & 7.59 & 4 & 212 & 44.9 & 0.09 & 3.5 & 14.3 \\
\hline $6 / 17 / 2013$ & 10:03:09.7 & 44.3873 & -112.6345 & $0.0 \mathrm{Mc} \mathrm{IE}$ & 82.9 & 5.04 & 4 & 194 & 29.8 & 0.10 & 4.5 & 13.0 \\
\hline $6 / 17 / 2013$ & $17: 24: 26.2$ & 43.0937 & -111.1720 & $0.6 \mathrm{Mc} \mathrm{IE}$ & 144.4 & 5.09 & 4 & 217 & 16.8 & 0.01 & 4.1 & 10.0 \\
\hline $6 / 18 / 2013$ & $07: 23: 51.4$ & 43.4155 & -111.1490 & $0.7 \mathrm{Mc} \mathrm{IE}$ & 134.6 & 3.98 & 6 & 278 & 18.1 & 0.04 & 1.6 & 10.5 \\
\hline $6 / 18 / 2013$ & $15: 02: 20.1$ & 42.6843 & -111.3573 & 1.2 Mc IE & 158.0 & 5.00 & 5 & 208 & 22.9 & 0.01 & 1.9 & 11.8 \\
\hline $6 / 18 / 2013$ & $15: 30: 02.8$ & 42.6123 & -111.6250 & 1.4 Mc IE & 149.0 & 3.42 & 8 & 145 & 46.2 & 0.03 & 0.7 & 11.2 \\
\hline $6 / 19 / 2013$ & $07: 11: 27.4$ & 42.9273 & -111.5487 & 1.9 Mc IE & 128.4 & 8.20 & 10 & 268 & 10.4 & 0.06 & 1.3 & 1.0 \\
\hline $6 / 19 / 2013$ & $08: 05: 31.8$ & 44.3647 & -113.3740 & $1.5 \mathrm{Mc} \mathrm{IE}$ & 92.5 & 24.35 & 4 & 195 & 6.5 & 0.00 & 1.5 & 1.6 \\
\hline $6 / 19 / 2013$ & $17: 41: 03.4$ & 43.7462 & -110.9125 & 1.1 Mc IE & 151.1 & 7.67 & 7 & 135 & 15.1 & 0.03 & 0.6 & 4.0 \\
\hline
\end{tabular}


Table C-2. Continued.

\begin{tabular}{|c|c|c|c|c|c|c|c|c|c|c|c|c|}
\hline ORIGIN & TIME & LAT N & LONG W & MAG-TYP & DIST & Z & NO & GAP & DMIN & RMS & ERH & ERZ \\
\hline $6 / 20 / 2013$ & $05: 35: 30.5$ & 43.7003 & -111.1003 & 1.1 Mc IE & 135.7 & 8.24 & 7 & 203 & 9.1 & 0.07 & 1.3 & 2.3 \\
\hline $6 / 20 / 2013$ & $14: 01: 07.3$ & 44.3835 & -114.0943 & $2.0 \mathrm{Mc} \mathrm{IE}$ & 133.1 & 5.14 & 5 & 227 & 55.5 & 0.18 & 3.6 & 9.9 \\
\hline $6 / 21 / 2013$ & $04: 50: 46.3$ & 42.9253 & -111.5612 & 0.0 NoMag & 127.8 & 6.28 & 4 & 292 & 11.5 & 0.00 & 2.8 & 5.1 \\
\hline $6 / 21 / 2013$ & $04: 51: 19.6$ & 42.9305 & -111.5527 & $1.0 \mathrm{Mc} \mathrm{IE}$ & 127.9 & 6.09 & 4 & 291 & 10.7 & 0.01 & 2.8 & 4.8 \\
\hline $6 / 22 / 2013$ & $22: 42: 55.7$ & 44.1717 & -114.0490 & $1.5 \mathrm{Mc} \mathrm{IE}$ & 117.0 & 6.46 & 4 & 208 & 55.0 & 0.00 & 1.7 & 5.0 \\
\hline $6 / 22 / 2013$ & $23: 58: 58.1$ & 43.4202 & -111.3512 & 1.1 Mc IE & 118.5 & 5.00 & 5 & 309 & 33.3 & 0.04 & 1.4 & 12.9 \\
\hline $6 / 23 / 2013$ & $07: 52: 23.7$ & 44.4270 & -113.3633 & $0.9 \mathrm{ML}$ IE & 98.2 & 12.27 & 9 & 207 & 13.3 & 0.06 & 1.6 & 1.1 \\
\hline $6 / 23 / 2013$ & $22: 09: 34.1$ & 44.1997 & -113.3493 & 1.2 Mc IE & 76.2 & 4.81 & 5 & 145 & 13.1 & 0.05 & 6.8 & 7.8 \\
\hline $6 / 25 / 2013$ & 09:14:41.1 & 43.2757 & -111.1225 & $0.8 \mathrm{Mc} \mathrm{IE}$ & 140.6 & 5.00 & 6 & 304 & 24.0 & 0.05 & 1.5 & 12.0 \\
\hline $6 / 25 / 2013$ & $15: 30: 16.8$ & 43.3795 & -111.0410 & $0.5 \mathrm{Mc} \mathrm{IE}$ & 144.0 & 9.63 & 6 & 266 & 14.3 & 0.07 & 0.9 & 1.7 \\
\hline $6 / 26 / 2013$ & $14: 23: 14.9$ & 42.6728 & -112.0277 & 1.1 Mc IE & 124.8 & 2.50 & 5 & 122 & 35.6 & 0.29 & 2.4 & 26.9 \\
\hline $6 / 26 / 2013$ & $14: 36: 09.2$ & 44.5168 & -111.2403 & 1.3 Mc IE & 156.7 & 1.28 & 5 & 244 & 36.6 & 0.01 & 3.1 & 1.4 \\
\hline $6 / 26 / 2013$ & $17: 14: 59.3$ & 43.2203 & -110.9270 & $0.8 \mathrm{Mc} \mathrm{IE}$ & 157.6 & 2.87 & 4 & 327 & 16.9 & 0.01 & 4.2 & 11.8 \\
\hline $6 / 26 / 2013$ & $19: 33: 12.4$ & 43.2650 & -111.3650 & $0.6 \mathrm{Mc} \mathrm{IE}$ & 122.4 & 4.99 & 5 & 211 & 23.5 & 0.03 & 1.0 & 10.3 \\
\hline $6 / 27 / 2013$ & $00: 05: 23.4$ & 44.5700 & -112.7872 & 1.2 Mc IE & 102.3 & 1.07 & 5 & 120 & 29.1 & 0.01 & 0.8 & 6.2 \\
\hline $6 / 27 / 2013$ & 04:01:20.4 & 43.2662 & -111.2528 & $0.6 \mathrm{Mc} \mathrm{IE}$ & 130.9 & 4.55 & 5 & 201 & 25.5 & 0.08 & 2.1 & 11.5 \\
\hline $6 / 27 / 2013$ & $13: 30: 07.5$ & 44.3487 & -113.0510 & 1.0 Mc IE & 80.6 & 9.83 & 5 & 114 & 9.0 & 0.03 & 0.8 & 2.5 \\
\hline $6 / 27 / 2013$ & $14: 59: 39.0$ & 43.2303 & -110.9315 & 1.3 Mc IE & 156.9 & 4.59 & 7 & 211 & 16.0 & 0.02 & 0.9 & 7.1 \\
\hline $6 / 27 / 2013$ & $20: 33: 29.1$ & 43.5700 & -111.1845 & $0.7 \mathrm{Mc} \mathrm{IE}$ & 129.3 & 8.55 & 7 & 258 & 14.8 & 0.09 & 0.9 & 2.3 \\
\hline $6 / 28 / 2013$ & $08: 37: 53.6$ & 43.8052 & -111.0520 & $0.7 \mathrm{Mc} \mathrm{IE}$ & 140.5 & 8.22 & 6 & 228 & 13.7 & 0.05 & 2.0 & 1.7 \\
\hline $6 / 28 / 2013$ & $17: 33: 43.8$ & 44.8603 & -111.7162 & 1.7 Mc IE & 159.3 & 5.15 & 5 & 241 & 15.0 & 0.01 & 2.3 & 1.4 \\
\hline $6 / 29 / 2013$ & 01:17:33.6 & 44.7070 & -111.5502 & $1.5 \mathrm{Mc} \mathrm{IE}$ & 153.4 & 3.04 & 4 & 225 & 9.5 & 0.29 & 19.7 & 18.5 \\
\hline $6 / 29 / 2013$ & $06: 01: 27.2$ & 44.1942 & -114.0422 & 1.4 Mc IE & 117.8 & 6.75 & 6 & 210 & 52.5 & 0.10 & 1.5 & 6.2 \\
\hline $6 / 29 / 2013$ & $11: 53: 05.9$ & 44.3335 & -113.9488 & 1.6 Mc IE & 120.5 & 7.31 & 6 & 213 & 43.4 & 0.04 & 1.2 & 12.9 \\
\hline $6 / 30 / 2013$ & $06: 51: 49.1$ & 44.3333 & -113.9488 & 1.4 Mc IE & 120.5 & 6.97 & 6 & 213 & 43.4 & 0.10 & 0.9 & 15.0 \\
\hline $6 / 30 / 2013$ & $16: 14: 19.7$ & 42.7587 & -111.3438 & $1.5 \mathrm{Mc} \mathrm{IE}$ & 153.3 & 2.52 & 7 & 256 & 19.9 & 0.08 & 0.9 & 13.4 \\
\hline $6 / 30 / 2013$ & $16: 24: 58.5$ & 42.7240 & -111.3593 & 1.1 Mc IE & 154.9 & 14.27 & 7 & 249 & 21.7 & 0.05 & 1.3 & 0.9 \\
\hline $6 / 30 / 2013$ & $20: 51: 27.3$ & 44.4933 & -114.1842 & $2.1 \mathrm{Mc} \mathrm{IE}$ & 146.2 & 12.06 & 7 & 240 & 65.3 & 0.20 & 1.8 & 2.6 \\
\hline $7 / 1 / 2013$ & $00: 03: 52.8$ & 44.1828 & -111.1242 & $0.0 \mathrm{Mc} \mathrm{IE}$ & 145.8 & 28.69 & 4 & 321 & 35.8 & 0.81 & 42.8 & 53.8 \\
\hline $7 / 1 / 2013$ & $05: 24: 02.0$ & 42.8910 & -111.2410 & $0.4 \mathrm{Mc} \mathrm{IE}$ & 150.9 & 4.98 & 5 & 150 & 15.6 & 0.07 & 0.7 & 11.5 \\
\hline $7 / 1 / 2013$ & $20: 50: 37.4$ & 42.4215 & -111.8403 & 1.6 Mc IE & 156.8 & 8.57 & 5 & 300 & 66.9 & 0.21 & 3.1 & 6.4 \\
\hline $7 / 1 / 2013$ & $21: 41: 28.9$ & 44.2115 & -112.5777 & 1.8 ML IE & 64.6 & 0.02 & 10 & 88 & 25.3 & 0.10 & 0.6 & 1.5 \\
\hline $7 / 2 / 2013$ & 21:03:17.4 & 43.4002 & -111.1515 & 1.8 ML IE & 134.7 & 7.05 & 6 & 281 & 19.1 & 0.03 & 3.1 & 11.0 \\
\hline $7 / 2 / 2013$ & 21:08:33.5 & 43.4025 & -111.1285 & 2.7 ML IE & 136.5 & 10.26 & 9 & 276 & 17.4 & 0.06 & 1.8 & 3.1 \\
\hline $7 / 3 / 2013$ & $19: 45: 58.6$ & 45.0505 & -112.9065 & $2.0 \mathrm{Mc} \mathrm{IE}$ & 156.1 & 5.03 & 6 & 212 & 25.2 & 0.00 & 3.1 & 2.0 \\
\hline $7 / 3 / 2013$ & $21: 30: 26.3$ & 42.8595 & -111.4878 & 1.4 Mc IE & 137.1 & 0.02 & 14 & 217 & 10.3 & 0.28 & 1.0 & 0.9 \\
\hline $7 / 4 / 2013$ & $02: 35: 14.1$ & 43.4362 & -110.9550 & 2.1 ML IE & 149.6 & 8.53 & 8 & 212 & 6.0 & 0.09 & 2.2 & 1.0 \\
\hline $7 / 5 / 2013$ & $06: 46: 53.1$ & 43.4773 & -110.8875 & 1.4 Mc IE & 154.3 & 11.49 & 13 & 111 & 5.3 & 0.14 & 0.5 & 0.7 \\
\hline $7 / 6 / 2013$ & 02:03:01.0 & 43.5242 & -110.9080 & 1.1 Mc IE & 152.0 & 9.21 & 8 & 155 & 5.1 & 0.06 & 0.7 & 1.5 \\
\hline $7 / 6 / 2013$ & 03:23:08.8 & 43.5132 & -110.9115 & $0.9 \mathrm{Mc} \mathrm{IE}$ & 151.8 & 11.07 & 10 & 97 & 4.1 & 0.07 & 0.5 & 1.1 \\
\hline $7 / 7 / 2013$ & $07: 22: 26.4$ & 44.4153 & -114.1010 & $2.9 \mathrm{ML}$ IE & 135.6 & 9.92 & 12 & 126 & 75.0 & 0.07 & 0.8 & 1.1 \\
\hline $7 / 7 / 2013$ & $13: 43: 08.1$ & 42.8492 & -111.4275 & $1.5 \mathrm{Mc}$ IE & 141.6 & 1.70 & 4 & 304 & 9.9 & 0.04 & 9.7 & 13.0 \\
\hline $7 / 7 / 2013$ & $14: 14: 50.1$ & 44.4162 & -114.0997 & 1.6 Mc IE & 135.6 & 6.94 & 5 & 229 & 75.0 & 0.03 & 0.8 & 12.7 \\
\hline $7 / 7 / 2013$ & $14: 24: 22.7$ & 44.1702 & -114.0113 & $1.5 \mathrm{Mc} \mathrm{IE}$ & 114.3 & 11.65 & 6 & 205 & 52.3 & 0.06 & 1.8 & 7.2 \\
\hline $7 / 7 / 2013$ & $17: 49: 41.4$ & 42.9262 & -111.4593 & 1.0 Mc IE & 134.2 & 1.17 & 9 & 266 & 3.4 & 0.10 & 1.3 & 0.6 \\
\hline $7 / 9 / 2013$ & $06: 24: 11.6$ & 44.6543 & -111.5978 & 1.1 Mc IE & 146.5 & 4.80 & 4 & 181 & 10.0 & 0.18 & 19.0 & 17.1 \\
\hline $7 / 10 / 2013$ & $05: 58: 52.1$ & 43.5718 & -110.9248 & $0.7 \mathrm{Mc} \mathrm{IE}$ & 150.2 & 2.32 & 7 & 118 & 9.3 & 0.08 & 0.7 & 13.8 \\
\hline $7 / 10 / 2013$ & $15: 35: 58.8$ & 42.6982 & -111.6540 & 1.5 ML IE & 140.1 & 5.64 & 9 & 135 & 32.7 & 0.06 & 0.7 & 4.3 \\
\hline $7 / 10 / 2013$ & $20: 02: 10.0$ & 42.9903 & -111.3685 & $0.6 \mathrm{Mc} \mathrm{IE}$ & 136.2 & 14.25 & 6 & 142 & 7.0 & 0.06 & 1.7 & 0.4 \\
\hline $7 / 12 / 2013$ & $02: 00: 33.0$ & 43.3168 & -110.9957 & $0.9 \mathrm{Mc} \mathrm{IE}$ & 149.2 & 2.56 & 5 & 290 & 12.7 & 0.06 & 3.2 & 11.1 \\
\hline $7 / 12 / 2013$ & 03:06:37.3 & 44.6418 & -112.7063 & 1.3 Mc IE & 110.5 & 8.60 & 7 & 130 & 23.5 & 0.06 & 1.1 & 12.5 \\
\hline
\end{tabular}


Table C-2. Continued.

\begin{tabular}{|c|c|c|c|c|c|c|c|c|c|c|c|c|}
\hline ORIGIN & TIME & LAT N & LONG W & MAG-TYP & DIST & $z$ & NO & GAP & DMIN & RMS & $\mathrm{ERH}$ & ERZ \\
\hline $7 / 12 / 2013$ & $23: 36: 55.7$ & 44.3988 & -114.0960 & 1.8 Mc IE & 134.2 & 18.26 & 5 & 227 & 73.4 & 0.05 & 0.8 & 13.3 \\
\hline $7 / 13 / 2013$ & $00: 11: 32.7$ & 44.3605 & -114.0448 & 1.7 ML IE & 128.4 & 3.67 & 14 & 106 & 67.5 & 0.10 & 1.2 & 3.7 \\
\hline $7 / 14 / 2013$ & $11: 31: 50.3$ & 44.6670 & -112.4277 & $1.0 \mathrm{Mc} \mathrm{IE}$ & 116.7 & 8.67 & 4 & 171 & 8.6 & 0.00 & 2.2 & 2.6 \\
\hline $7 / 14 / 2013$ & $12: 39: 07.8$ & 44.7412 & -111.7347 & 1.9 Mc IE & 147.5 & 6.79 & 6 & 226 & 87.8 & 0.06 & 1.3 & 2.0 \\
\hline $7 / 14 / 2013$ & $17: 23: 48.6$ & 44.7697 & -111.7247 & 1.9 Mc IE & 150.5 & 8.57 & 9 & 190 & 56.6 & 0.07 & 1.2 & 2.8 \\
\hline $7 / 15 / 2013$ & $16: 38: 25.3$ & 43.1738 & -111.3493 & $0.9 \mathrm{Mc}$ IE & 127.6 & 2.50 & 6 & 194 & 13.5 & 0.09 & 1.3 & 13.6 \\
\hline $7 / 15 / 2013$ & $17: 03: 15.4$ & 43.1878 & -111.3710 & 1.2 Mc IE & 125.3 & 5.39 & 6 & 118 & 14.9 & 0.06 & 1.6 & 12.0 \\
\hline $7 / 16 / 2013$ & $13: 35: 08.1$ & 42.9513 & -111.5970 & 1.1 Mc IE & 123.7 & 3.54 & 4 & 269 & 21.7 & 0.03 & 8.6 & 12.0 \\
\hline $7 / 16 / 2013$ & $21: 36: 06.1$ & 45.0768 & -112.8378 & $1.8 \mathrm{Mc} \mathrm{IE}$ & 158.8 & 16.10 & 9 & 172 & 37.0 & 0.23 & 8.5 & 19.9 \\
\hline $7 / 17 / 2013$ & $04: 18: 12.6$ & 42.9957 & -111.4248 & $0.6 \mathrm{Mc}$ IE & 132.0 & 9.21 & 7 & 217 & 6.4 & 0.07 & 1.2 & 2.2 \\
\hline $7 / 17 / 2013$ & $12: 33: 16.6$ & 43.4105 & -111.1240 & 1.4 Mc IE & 136.7 & 3.28 & 6 & 199 & 16.6 & 0.01 & 1.5 & 10.3 \\
\hline $7 / 17 / 2013$ & $13: 03: 11.7$ & 43.4205 & -111.1055 & $0.5 \mathrm{Mc} \mathrm{IE}$ & 137.9 & 11.68 & 6 & 267 & 14.7 & 0.04 & 1.0 & 2.5 \\
\hline $7 / 17 / 2013$ & $13: 37: 21.4$ & 43.4178 & -111.1170 & 1.2 Mc IE & 137.1 & 0.03 & 7 & 211 & 15.7 & 0.16 & 1.0 & 2.7 \\
\hline $7 / 17 / 2013$ & $13: 42: 18.7$ & 43.4187 & -111.1012 & 2.4 ML IE & 138.3 & 6.73 & 21 & 77 & 14.5 & 0.04 & 0.3 & 2.1 \\
\hline $7 / 17 / 2013$ & $13: 47: 22.5$ & 43.4890 & -110.9598 & $0.5 \mathrm{Mc} \mathrm{IE}$ & 148.3 & 19.69 & 4 & 292 & 0.8 & 0.04 & 12.9 & 1.4 \\
\hline $7 / 17 / 2013$ & $13: 49: 20.2$ & 43.4195 & -111.1292 & $0.9 \mathrm{Mc}$ IE & 136.1 & 9.52 & 5 & 316 & 16.5 & 0.11 & 1.4 & 4.4 \\
\hline $7 / 17 / 2013$ & $17: 26: 25.7$ & 43.4077 & -111.1447 & $0.6 \mathrm{Mc} \mathrm{IE}$ & 135.1 & 2.32 & 6 & 275 & 18.2 & 0.06 & 1.3 & 13.1 \\
\hline $7 / 17 / 2013$ & $19: 45: 25.9$ & 43.4162 & -111.0920 & 1.8 Mc IE & 139.1 & 7.55 & 9 & 112 & 20.4 & 0.09 & 0.6 & 5.7 \\
\hline $7 / 17 / 2013$ & $20: 04: 26.7$ & 43.4913 & -110.9672 & $0.9 \mathrm{Mc} \mathrm{IE}$ & 147.7 & 19.47 & 4 & 309 & 1.3 & 0.02 & 12.6 & 1.1 \\
\hline $7 / 17 / 2013$ & $22: 13: 06.7$ & 43.4322 & -111.1003 & $0.9 \mathrm{Mc} \mathrm{IE}$ & 138.1 & 2.09 & 7 & 264 & 13.7 & 0.22 & 1.6 & 22.2 \\
\hline $7 / 18 / 2013$ & 04:49:08.8 & 43.4165 & -111.0980 & $0.9 \mathrm{Mc}$ IE & 138.6 & 4.73 & 4 & 267 & 14.5 & 0.02 & 1.5 & 10.4 \\
\hline $7 / 18 / 2013$ & $06: 20: 09.4$ & 44.1602 & -114.5113 & 3.3 Mc MB & 149.9 & 5.22 & 18 & 108 & 66.9 & 0.06 & 0.6 & 1.7 \\
\hline $7 / 18 / 2013$ & $06: 36: 03.0$ & 43.4172 & -111.1192 & $2.0 \mathrm{Mc} \mathrm{IE}$ & 136.9 & 5.97 & 13 & 197 & 15.9 & 0.07 & 0.7 & 3.2 \\
\hline $7 / 18 / 2013$ & $06: 39: 58.4$ & 43.4253 & -111.1087 & 1.3 Mc IE & 137.6 & 2.46 & 10 & 132 & 14.7 & 0.12 & 0.5 & 14.9 \\
\hline $7 / 18 / 2013$ & $08: 37: 44.1$ & 43.4208 & -111.0945 & $1.5 \mathrm{Mc} \mathrm{IE}$ & 138.8 & 8.29 & 7 & 152 & 14.0 & 0.09 & 0.7 & 2.8 \\
\hline $7 / 18 / 2013$ & $10: 27: 49.5$ & 43.4185 & -111.0922 & $1.5 \mathrm{Mc} \mathrm{IE}$ & 139.0 & 8.57 & 11 & 103 & 13.9 & 0.07 & 0.5 & 2.6 \\
\hline $7 / 18 / 2013$ & $11: 20: 32.8$ & 43.4093 & -111.1287 & $0.9 \mathrm{Mc}$ IE & 136.3 & 0.03 & 6 & 272 & 17.0 & 0.11 & 3.1 & 3.8 \\
\hline $7 / 18 / 2013$ & $13: 43: 29.1$ & 43.4195 & -111.0980 & 2.1 ML IE & 138.5 & 9.08 & 13 & 146 & 14.3 & 0.06 & 0.5 & 1.2 \\
\hline $7 / 18 / 2013$ & $16: 56: 31.5$ & 43.4077 & -111.1350 & $0.9 \mathrm{Mc} \mathrm{IE}$ & 135.9 & 4.36 & 6 & 274 & 17.5 & 0.14 & 2.2 & 10.9 \\
\hline $7 / 18 / 2013$ & 19:09:37.3 & 43.4277 & -111.1093 & $0.3 \mathrm{Mc} \mathrm{IE}$ & 137.4 & 11.14 & 5 & 266 & 14.6 & 0.06 & 1.1 & 4.0 \\
\hline $7 / 18 / 2013$ & $22: 25: 46.5$ & 42.5762 & -111.5787 & 1.4 Mc IE & 154.5 & 5.00 & 9 & 237 & 42.2 & 0.17 & 1.4 & 16.2 \\
\hline $7 / 18 / 2013$ & $22: 27: 23.2$ & 42.6037 & -111.5557 & 1.1 Mc IE & 153.3 & 5.01 & 5 & 231 & 41.4 & 0.08 & 1.2 & 13.0 \\
\hline $7 / 19 / 2013$ & $00: 50: 12.2$ & 42.6547 & -111.5690 & 1.0 Mc IE & 148.3 & 5.50 & 7 & 219 & 33.7 & 0.04 & 1.3 & 3.7 \\
\hline $7 / 19 / 2013$ & $06: 16: 60.0$ & 43.4852 & -110.9575 & $0.3 \mathrm{Mc} \mathrm{IE}$ & 148.5 & 19.99 & 4 & 257 & 0.8 & 0.04 & 12.9 & 1.4 \\
\hline $7 / 19 / 2013$ & $11: 29: 41.4$ & 43.4188 & -111.1078 & $0.3 \mathrm{Mc} \mathrm{IE}$ & 137.8 & 11.87 & 6 & 269 & 15.0 & 0.06 & 1.1 & 2.6 \\
\hline $7 / 19 / 2013$ & $14: 43: 10.1$ & 43.4058 & -111.1470 & $0.6 \mathrm{Mc} \mathrm{IE}$ & 134.9 & 6.32 & 7 & 279 & 18.4 & 0.06 & 1.8 & 6.2 \\
\hline $7 / 19 / 2013$ & $14: 49: 29.5$ & 42.5965 & -111.5638 & 2.0 ML IE & 153.5 & 9.21 & 14 & 95 & 39.7 & 0.07 & 0.5 & 1.4 \\
\hline $7 / 19 / 2013$ & $14: 58: 58.1$ & 42.5993 & -111.5658 & $1.8 \mathrm{Mc} \mathrm{IE}$ & 153.2 & 9.81 & 10 & 123 & 42.4 & 0.04 & 0.4 & 1.3 \\
\hline $7 / 19 / 2013$ & $15: 01: 04.7$ & 42.6037 & -111.5665 & 1.8 Mc IE & 152.8 & 2.61 & 8 & 152 & 39.0 & 0.09 & 0.9 & 13.6 \\
\hline $7 / 19 / 2013$ & $15: 02: 52.8$ & 42.8355 & -111.5498 & $2.3 \mathrm{Mc} \mathrm{IE}$ & 135.0 & 7.29 & 5 & 289 & 15.5 & 0.00 & 7.6 & 1.7 \\
\hline $7 / 19 / 2013$ & $15: 09: 50.3$ & 42.6257 & -111.5603 & 1.3 Mc IE & 151.2 & 5.05 & 5 & 272 & 40.8 & 0.04 & 2.2 & 11.7 \\
\hline $7 / 19 / 2013$ & $15: 18: 26.8$ & 42.5922 & -111.5663 & 1.3 Mc IE & 153.8 & 5.03 & 4 & 183 & 42.8 & 0.22 & 1.4 & 21.7 \\
\hline $7 / 19 / 2013$ & $15: 22: 55.4$ & 42.6077 & -111.5773 & 1.6 Mc IE & 151.8 & 5.02 & 4 & 277 & 52.3 & 0.04 & 0.9 & 13.0 \\
\hline $7 / 19 / 2013$ & $18: 36: 22.3$ & 42.5985 & -111.5935 & 1.7 Mc IE & 151.8 & 4.99 & 9 & 231 & 40.3 & 0.20 & 2.3 & 15.9 \\
\hline $7 / 19 / 2013$ & $18: 38: 01.1$ & 42.6072 & -111.5708 & 1.6 Mc IE & 152.2 & 4.99 & 5 & 151 & 42.4 & 0.08 & 0.9 & 13.0 \\
\hline $7 / 19 / 2013$ & $19: 45: 59.2$ & 44.6947 & -111.9957 & 1.2 Mc IE & 132.2 & 9.62 & 5 & 190 & 26.4 & 0.03 & 2.2 & 2.2 \\
\hline $7 / 20 / 2013$ & 08:04:34.0 & 43.4017 & -111.1483 & $0.7 \mathrm{Mc} \mathrm{IE}$ & 134.9 & 3.31 & 7 & 276 & 18.8 & 0.04 & 1.8 & 11.0 \\
\hline $7 / 20 / 2013$ & $15: 43: 20.6$ & 43.4215 & -111.0963 & $0.8 \mathrm{Mc} \mathrm{IE}$ & 138.6 & 7.26 & 8 & 152 & 14.0 & 0.15 & 0.7 & 4.0 \\
\hline $7 / 20 / 2013$ & $21: 19: 44.4$ & 44.2465 & -113.1570 & 1.0 Mc IE & 72.8 & 8.93 & 5 & 131 & 19.5 & 0.05 & 1.5 & 12.6 \\
\hline $7 / 20 / 2013$ & $22: 49: 00.2$ & 44.2325 & -113.1502 & $1.5 \mathrm{Mc} \mathrm{IE}$ & 71.2 & 5.69 & 9 & 85 & 22.1 & 0.02 & 0.4 & 0.9 \\
\hline $7 / 21 / 2013$ & $10: 20: 34.8$ & 43.4197 & -111.1138 & $0.9 \mathrm{Mc} \mathrm{IE}$ & 137.3 & 2.51 & 8 & 168 & 15.4 & 0.22 & 0.8 & 19.5 \\
\hline
\end{tabular}


Table C-2. Continued.

\begin{tabular}{|c|c|c|c|c|c|c|c|c|c|c|c|c|}
\hline ORIGIN & TIME & LAT N & LONG W & MAG-TYP & DIST & Z & NO & GAP & DMIN & RMS & $\mathrm{ERH}$ & ERZ \\
\hline $7 / 21 / 2013$ & $15: 21: 03.2$ & 43.7438 & -110.9223 & $0.8 \mathrm{Mc} \mathrm{IE}$ & 150.3 & 4.18 & 5 & 189 & 14.5 & 0.02 & 2.8 & 9.6 \\
\hline $7 / 21 / 2013$ & $15: 21: 56.6$ & 43.7412 & -110.9130 & $0.5 \mathrm{Mc} \mathrm{IE}$ & 151.0 & 4.29 & 5 & 193 & 14.7 & 0.03 & 2.8 & 10.0 \\
\hline $7 / 24 / 2013$ & $01: 00: 36.2$ & 43.8133 & -110.8942 & $1.0 \mathrm{Mc} \mathrm{IE}$ & 153.2 & 5.80 & 8 & 123 & 10.0 & 0.10 & 0.8 & 2.6 \\
\hline $7 / 24 / 2013$ & $19: 45: 18.2$ & 43.5337 & -110.8748 & $0.1 \mathrm{Mc}$ IE & 154.6 & 2.87 & 5 & 164 & 7.8 & 0.07 & 0.7 & 10.6 \\
\hline $7 / 25 / 2013$ & $15: 54: 17.2$ & 45.0432 & -112.8712 & $1.5 \mathrm{Mc} \mathrm{IE}$ & 155.2 & 0.02 & 4 & 327 & 24.0 & 0.13 & 7.3 & 5.5 \\
\hline $7 / 26 / 2013$ & 02:19:04.5 & 44.4692 & -112.8282 & $0.6 \mathrm{Mc} \mathrm{IE}$ & 91.2 & 6.79 & 4 & 143 & 18.0 & 0.11 & 1.2 & 15.5 \\
\hline $7 / 26 / 2013$ & $08: 56: 25.7$ & 44.4087 & -114.0598 & 1.1 Mc IE & 132.6 & 7.34 & 5 & 226 & 53.3 & 0.05 & 0.9 & 13.1 \\
\hline $7 / 27 / 2013$ & $16: 19: 29.1$ & 43.8878 & -113.7402 & $2.0 \mathrm{Mc} \mathrm{IE}$ & 81.5 & 4.89 & 7 & 245 & 23.6 & 0.12 & 1.3 & 1.6 \\
\hline $7 / 27 / 2013$ & $16: 28: 22.9$ & 43.8897 & -113.7287 & 1.6 Mc IE & 80.6 & 6.34 & 7 & 242 & 22.7 & 0.10 & 1.2 & 1.1 \\
\hline $7 / 27 / 2013$ & $17: 05: 20.7$ & 43.8993 & -113.7522 & 1.2 Mc IE & 82.8 & 7.11 & 8 & 156 & 24.3 & 0.12 & 1.2 & 15.8 \\
\hline $7 / 28 / 2013$ & $15: 49: 11.0$ & 42.6567 & -111.3983 & $0.8 \mathrm{Mc} \mathrm{IE}$ & 157.7 & 13.58 & 5 & 267 & 27.2 & 0.00 & 6.8 & 1.1 \\
\hline $7 / 28 / 2013$ & $17: 35: 10.2$ & 44.1583 & -113.7183 & 1.2 Mc IE & 94.0 & 2.99 & 7 & 263 & 30.2 & 0.30 & 8.1 & 3.7 \\
\hline $7 / 29 / 2013$ & $14: 04: 45.0$ & 42.4882 & -111.7708 & 1.7 Mc IE & 153.3 & 5.00 & 4 & 150 & 59.0 & 0.11 & 1.0 & 14.6 \\
\hline $7 / 29 / 2013$ & $23: 24: 37.9$ & 43.1688 & -111.3997 & 1.0 Mc IE & 124.1 & 15.39 & 5 & 181 & 13.0 & 0.10 & 13.8 & 4.3 \\
\hline $7 / 31 / 2013$ & $10: 13: 22.6$ & 43.0307 & -111.2505 & 1.7 Mc IE & 142.0 & 1.85 & 8 & 196 & 10.1 & 0.10 & 1.1 & 3.3 \\
\hline $7 / 31 / 2013$ & $11: 06: 37.2$ & 44.3043 & -114.5212 & $1.5 \mathrm{Mc} \mathrm{IE}$ & 157.2 & 1.24 & 6 & 302 & 82.9 & 0.08 & 7.1 & 7.8 \\
\hline $8 / 3 / 2013$ & $00: 15: 31.1$ & 44.5795 & -112.7853 & 1.0 Mc IE & 103.4 & 1.25 & 4 & 145 & 28.0 & 0.21 & 1.2 & 21.3 \\
\hline $8 / 3 / 2013$ & $08: 18: 11.2$ & 44.5403 & -114.0252 & $2.5 \mathrm{ML} U S$ & 140.3 & 1.21 & 11 & 234 & 82.0 & 0.06 & 0.9 & 2.8 \\
\hline $8 / 4 / 2013$ & $12: 31: 40.6$ & 44.6872 & -112.0942 & 1.4 Mc IE & 127.8 & 7.49 & 7 & 194 & 26.0 & 0.06 & 1.2 & 13.3 \\
\hline 8/7/2013 & 05:48:11.0 & 44.5735 & -112.7688 & 1.0 Mc IE & 102.8 & 6.40 & 6 & 141 & 28.9 & 0.04 & 0.8 & 12.8 \\
\hline $8 / 12 / 2013$ & $04: 16: 48.5$ & 44.6290 & -112.4188 & 1.7 Mc IE & 112.7 & 5.94 & 14 & 88 & 4.4 & 0.08 & 0.6 & 1.0 \\
\hline $8 / 12 / 2013$ & $04: 36: 31.8$ & 44.5058 & -111.2583 & 1.2 Mc IE & 154.8 & 4.69 & 7 & 326 & 35.6 & 0.32 & 12.3 & 25.1 \\
\hline $8 / 12 / 2013$ & $06: 34: 47.5$ & 44.6683 & -112.4085 & 1.1 Mc IE & 117.2 & 0.31 & 5 & 178 & 8.4 & 0.39 & 8.3 & 15.7 \\
\hline $8 / 13 / 2013$ & 04:58:50.5 & 42.9325 & -111.4007 & $0.8 \mathrm{Mc}$ IE & 137.6 & 3.91 & 5 & 164 & 1.8 & 0.05 & 4.1 & 5.5 \\
\hline $8 / 13 / 2013$ & 05:08:16.1 & 42.9495 & -111.3667 & $0.7 \mathrm{Mc} \mathrm{IE}$ & 138.8 & 2.61 & 5 & 122 & 4.7 & 0.28 & 2.9 & 19.7 \\
\hline $8 / 13 / 2013$ & $06: 26: 49.0$ & 42.5380 & -111.8337 & $0.9 \mathrm{Mc} \mathrm{IE}$ & 145.8 & 6.25 & 6 & 169 & 57.4 & 0.25 & 1.3 & 5.1 \\
\hline $8 / 13 / 2013$ & $16: 44: 51.4$ & 45.0373 & -112.4253 & 1.2 Mc IE & 156.9 & 0.31 & 4 & 197 & 38.6 & 0.05 & 1.4 & 13.1 \\
\hline $8 / 19 / 2013$ & $11: 42: 25.8$ & 44.2403 & -113.9860 & 1.7 Mc IE & 116.8 & 7.03 & 15 & 285 & 47.0 & 0.29 & 2.0 & 2.8 \\
\hline $8 / 20 / 2013$ & 01:35:59.5 & 44.0922 & -113.8038 & 1.4 Mc IE & 95.6 & 7.09 & 9 & 278 & 33.6 & 0.24 & 2.2 & 9.5 \\
\hline $8 / 21 / 2013$ & $07: 10: 36.1$ & 44.6627 & -112.5293 & 1.6 Mc IE & 114.5 & 6.05 & 9 & 128 & 13.2 & 0.19 & 0.6 & 10.5 \\
\hline $8 / 21 / 2013$ & $16: 42: 17.5$ & 44.4022 & -114.0903 & 1.6 Mc IE & 134.1 & 1.35 & 7 & 152 & 55.6 & 0.06 & 1.2 & 2.3 \\
\hline $8 / 21 / 2013$ & $17: 17: 32.2$ & 44.3993 & -114.0627 & 1.4 Mc IE & 132.2 & 0.07 & 6 & 276 & 53.3 & 0.06 & 3.6 & 4.1 \\
\hline $8 / 22 / 2013$ & $09: 34: 53.0$ & 43.1923 & -111.3797 & 1.1 Mc IE & 124.5 & 5.05 & 6 & 229 & 15.4 & 0.12 & 2.0 & 13.7 \\
\hline $8 / 22 / 2013$ & $16: 15: 26.8$ & 44.0268 & -113.8487 & 1.0 Mc IE & 95.4 & 6.45 & 5 & 300 & 33.7 & 0.14 & 7.0 & 14.6 \\
\hline $8 / 23 / 2013$ & $03: 11: 47.1$ & 43.1788 & -111.3438 & 1.2 Mc IE & 127.8 & 1.09 & 8 & 127 & 14.1 & 0.35 & 1.6 & 4.8 \\
\hline $8 / 23 / 2013$ & 06:08:55.2 & 43.4210 & -110.8637 & $0.5 \mathrm{Mc} \mathrm{IE}$ & 157.1 & 12.94 & 6 & 147 & 6.6 & 0.30 & 1.6 & 4.0 \\
\hline $8 / 23 / 2013$ & $07: 16: 42.1$ & 43.4568 & -110.8620 & 1.1 Mc IE & 156.6 & 2.11 & 7 & 125 & 8.1 & 0.16 & 0.7 & 17.8 \\
\hline $8 / 23 / 2013$ & $07: 30: 51.2$ & 42.9507 & -111.1325 & $0.0 \mathrm{Mc} \mathrm{IE}$ & 154.8 & 9.48 & 9 & 142 & 20.8 & 0.10 & 0.7 & 4.2 \\
\hline $8 / 23 / 2013$ & $14: 52: 09.0$ & 43.6333 & -114.1200 & $1.5 \mathrm{Mc} \mathrm{IE}$ & 107.8 & 6.34 & 7 & 310 & 63.0 & 0.18 & 3.9 & 9.5 \\
\hline $8 / 26 / 2013$ & $02: 12: 08.1$ & 44.6193 & -114.2005 & $1.8 \mathrm{Mc} \mathrm{IE}$ & 156.5 & 2.29 & 5 & 296 & 72.0 & 0.11 & 7.8 & 14.2 \\
\hline $8 / 26 / 2013$ & 04:59:37.4 & 43.1933 & -110.9430 & 1.3 Mc IE & 157.4 & 7.96 & 6 & 217 & 20.2 & 0.18 & 3.0 & 8.1 \\
\hline $8 / 27 / 2013$ & $07: 55: 21.5$ & 43.5008 & -110.8477 & $0.5 \mathrm{Mc} \mathrm{IE}$ & 157.1 & 2.50 & 6 & 125 & 8.4 & 0.11 & 0.6 & 11.9 \\
\hline $8 / 27 / 2013$ & $16: 12: 18.2$ & 42.7113 & -111.6633 & $1.8 \mathrm{Mc} \mathrm{IE}$ & 138.5 & 5.02 & 6 & 187 & 32.0 & 0.06 & 1.1 & 11.6 \\
\hline $8 / 27 / 2013$ & $22: 18: 55.3$ & 43.0893 & -111.7395 & 1.1 Mc IE & 105.1 & 4.93 & 6 & 317 & 30.3 & 0.52 & 5.8 & 43.4 \\
\hline $8 / 28 / 2013$ & 09:01:46.4 & 44.2078 & -112.8552 & 1.0 ML IE & 62.3 & 0.13 & 12 & 204 & 15.1 & 0.04 & 1.0 & 1.8 \\
\hline $8 / 28 / 2013$ & $13: 46: 36.8$ & 42.9285 & -111.3747 & $0.8 \mathrm{Mc} \mathrm{IE}$ & 139.6 & 13.43 & 7 & 158 & 4.0 & 0.05 & 1.8 & 2.7 \\
\hline $8 / 28 / 2013$ & $17: 53: 54.3$ & 44.7965 & -111.8197 & $3.0 \mathrm{Mc} M B$ & 148.9 & 4.83 & 13 & 136 & 14.3 & 0.09 & 0.5 & 0.6 \\
\hline $8 / 29 / 2013$ & $08: 21: 42.8$ & 44.7063 & -112.6787 & 1.3 Mc IE & 117.8 & 16.53 & 5 & 114 & 19.1 & 0.01 & 0.7 & 0.9 \\
\hline $8 / 29 / 2013$ & $21: 13: 00.0$ & 42.6880 & -111.6278 & 1.1 Mc IE & 142.4 & 4.12 & 8 & 132 & 32.5 & 0.13 & 0.9 & 15.4 \\
\hline $8 / 30 / 2013$ & 01:40:23.9 & 43.2067 & -111.3720 & $0.9 \mathrm{Mc} \mathrm{IE}$ & 124.4 & 4.86 & 6 & 300 & 45.6 & 0.08 & 1.2 & 14.2 \\
\hline $8 / 30 / 2013$ & $05: 15: 32.3$ & 43.6120 & -111.1197 & 1.2 Mc IE & 134.2 & 0.04 & 9 & 243 & 8.0 & 0.20 & 1.2 & 1.1 \\
\hline
\end{tabular}


Table C-2. Continued.

\begin{tabular}{|c|c|c|c|c|c|c|c|c|c|c|c|c|}
\hline ORIGIN & TIME & LAT N & LONG W & MAG-TYP & DIST & Z & NO & GAP & DMIN & RMS & $\mathrm{ERH}$ & ERZ \\
\hline $8 / 30 / 2013$ & $07: 26: 49.3$ & 44.1015 & -113.8845 & $1.8 \mathrm{Mc}$ IE & 101.8 & 1.50 & 13 & 257 & 39.7 & 0.07 & 0.7 & 1.6 \\
\hline $8 / 30 / 2013$ & $07: 29: 21.6$ & 44.5903 & -112.7968 & $1.5 \mathrm{Mc} \mathrm{IE}$ & 104.6 & 7.88 & 11 & 128 & 26.7 & 0.26 & 1.2 & 6.4 \\
\hline $8 / 30 / 2013$ & $13: 56: 09.3$ & 44.5702 & -112.7402 & 1.2 Mc IE & 102.4 & 0.16 & 5 & 127 & 27.6 & 0.12 & 1.0 & 9.5 \\
\hline $8 / 30 / 2013$ & $19: 00: 16.7$ & 42.8352 & -111.2250 & 1.2 Mc IE & 155.6 & 6.08 & 9 & 179 & 12.8 & 0.09 & 0.9 & 4.5 \\
\hline $8 / 31 / 2013$ & 01:22:29.1 & 44.4955 & -114.1927 & $1.5 \mathrm{Mc} \mathrm{IE}$ & 146.9 & 20.27 & 6 & 201 & 66.0 & 0.17 & 1.1 & 17.9 \\
\hline $8 / 31 / 2013$ & 09:22:04.8 & 43.2805 & -111.2278 & 1.1 Mc IE & 132.3 & 4.98 & 7 & 209 & 31.8 & 0.13 & 1.3 & 15.3 \\
\hline $8 / 31 / 2013$ & $12: 00: 34.4$ & 44.8448 & -112.9287 & 1.1 Mc IE & 133.4 & 4.46 & 8 & 171 & 6.6 & 0.11 & 1.0 & 1.2 \\
\hline $9 / 1 / 2013$ & $13: 41: 14.0$ & 44.2760 & -114.0758 & $2.4 \mathrm{Mc} \mathrm{IE}$ & 124.9 & 0.04 & 10 & 115 & 53.7 & 0.21 & 1.2 & 11.0 \\
\hline $9 / 1 / 2013$ & $13: 57: 05.6$ & 44.2535 & -114.0893 & 1.8 Mc IE & 124.5 & 1.25 & 8 & 196 & 55.0 & 0.35 & 10.0 & 22.0 \\
\hline $9 / 2 / 2013$ & 01:00:45.5 & 43.4243 & -111.1097 & $0.8 \mathrm{Mc}$ IE & 137.5 & 2.43 & 5 & 314 & 22.0 & 0.18 & 1.7 & 19.7 \\
\hline $9 / 2 / 2013$ & $16: 31: 25.9$ & 44.3482 & -113.9497 & 2.3 Mc IE & 121.6 & 6.96 & 9 & 279 & 43.6 & 0.03 & 2.7 & 12.7 \\
\hline $9 / 2 / 2013$ & $20: 42: 57.0$ & 44.0618 & -110.8665 & 1.2 Mc IE & 160.7 & 8.46 & 4 & 140 & 13.6 & 0.01 & 1.2 & 5.2 \\
\hline $9 / 3 / 2013$ & $00: 50: 13.2$ & 43.5832 & -111.0507 & 1.1 Mc IE & 140.0 & 9.05 & 8 & 163 & 6.4 & 0.02 & 0.6 & 0.6 \\
\hline $9 / 3 / 2013$ & $06: 47: 19.5$ & 44.2493 & -113.9742 & 1.9 Mc IE & 116.5 & 0.34 & 7 & 283 & 45.9 & 0.22 & 3.4 & 5.1 \\
\hline $9 / 3 / 2013$ & $12: 52: 17.8$ & 44.1532 & -113.9117 & 1.1 Mc IE & 106.5 & 4.40 & 5 & 285 & 44.1 & 0.03 & 5.5 & 9.5 \\
\hline $9 / 3 / 2013$ & $23: 04: 49.8$ & 43.1310 & -111.0622 & 1.0 Mc IE & 150.8 & 5.07 & 5 & 201 & 26.5 & 0.10 & 2.2 & 13.3 \\
\hline $9 / 3 / 2013$ & 23:19:19.6 & 43.4393 & -111.0830 & $0.6 \mathrm{Mc}$ IE & 139.3 & 5.35 & 6 & 257 & 12.1 & 0.30 & 7.8 & 20.9 \\
\hline $9 / 7 / 2013$ & $21: 46: 28.0$ & 44.5985 & -113.4648 & 1.1 Mc IE & 118.8 & 14.68 & 7 & 219 & 32.3 & 0.25 & 10.1 & 2.6 \\
\hline $9 / 8 / 2013$ & $05: 52: 14.3$ & 43.0780 & -111.3455 & $0.6 \mathrm{Mc}$ IE & 132.7 & 1.97 & 6 & 166 & 3.4 & 0.21 & 10.1 & 15.1 \\
\hline $9 / 8 / 2013$ & $06: 33: 16.9$ & 44.6960 & -111.8302 & $0.8 \mathrm{Mc}$ IE & 139.1 & 12.33 & 5 & 119 & 13.6 & 0.01 & 0.9 & 2.0 \\
\hline 9/9/2013 & 07:08:37.9 & 44.1873 & -112.4612 & 1.1 Mc IE & 65.1 & 5.58 & 7 & 203 & 38.8 & 0.13 & 0.9 & 13.0 \\
\hline $9 / 9 / 2013$ & $12: 36: 04.2$ & 43.1603 & -110.9863 & 1.0 Mc IE & 155.3 & 4.57 & 7 & 332 & 25.0 & 0.40 & 5.0 & 29.3 \\
\hline $9 / 10 / 2013$ & $12: 18: 51.0$ & 44.2292 & -114.0522 & 1.3 Mc IE & 120.5 & 6.63 & 6 & 160 & 52.4 & 0.15 & 1.3 & 4.9 \\
\hline $9 / 10 / 2013$ & $15: 38: 24.8$ & 44.5557 & -114.0140 & 1.4 Mc IE & 140.9 & 5.06 & 7 & 279 & 55.6 & 0.17 & 2.7 & 7.0 \\
\hline $9 / 10 / 2013$ & 23:00:09.0 & 42.8287 & -111.4073 & $0.4 \mathrm{Mc}$ IE & 144.3 & 2.42 & 5 & 250 & 12.2 & 0.18 & 2.0 & 19.0 \\
\hline $9 / 12 / 2013$ & $21: 22: 21.2$ & 42.8238 & -111.4967 & $0.8 \mathrm{Mc}$ IE & 139.1 & 2.50 & 5 & 280 & 14.1 & 0.09 & 11.7 & 13.2 \\
\hline $9 / 14 / 2013$ & $02: 36: 22.6$ & 44.4690 & -112.7638 & 1.3 Mc IE & 91.1 & 10.61 & 9 & 99 & 21.0 & 0.04 & 0.5 & 2.0 \\
\hline $9 / 14 / 2013$ & 21:58:18.6 & 42.9118 & -111.3748 & $0.4 \mathrm{Mc}$ IE & 140.7 & 2.51 & 5 & 183 & 4.8 & 0.04 & 2.0 & 10.1 \\
\hline $9 / 15 / 2013$ & $02: 26: 56.8$ & 42.9417 & -111.3007 & $0.8 \mathrm{Mc} \mathrm{IE}$ & 143.8 & 5.08 & 4 & 128 & 9.9 & 0.14 & 3.1 & 16.0 \\
\hline $9 / 15 / 2013$ & $05: 34: 56.7$ & 42.7417 & -111.6423 & 1.2 Mc IE & 137.1 & 5.04 & 8 & 121 & 28.3 & 0.25 & 1.4 & 18.4 \\
\hline $9 / 15 / 2013$ & $06: 18: 37.3$ & 42.9650 & -111.0805 & $0.5 \mathrm{Mc}$ IE & 157.7 & 12.66 & 6 & 163 & 22.2 & 0.03 & 0.9 & 3.4 \\
\hline $9 / 15 / 2013$ & 09:50:05.9 & 43.0580 & -111.3592 & $0.5 \mathrm{Mc}$ IE & 132.8 & 5.19 & 4 & 168 & 1.1 & 0.00 & 5.7 & 2.6 \\
\hline $9 / 16 / 2013$ & 01:19:24.7 & 44.6135 & -112.0875 & $1.5 \mathrm{Mc}$ IE & 120.8 & 10.76 & 11 & 163 & 24.5 & 0.12 & 0.6 & 1.8 \\
\hline $9 / 16 / 2013$ & $05: 43: 53.9$ & 43.7392 & -110.9073 & $0.3 \mathrm{Mc}$ IE & 151.5 & 4.65 & 5 & 258 & 14.8 & 0.05 & 3.4 & 12.8 \\
\hline $9 / 16 / 2013$ & $13: 56: 22.4$ & 43.7402 & -110.9138 & $0.7 \mathrm{Mc}$ IE & 150.9 & 3.19 & 7 & 135 & 14.5 & 0.05 & 0.4 & 9.4 \\
\hline $9 / 16 / 2013$ & $16: 06: 56.7$ & 43.7970 & -110.9005 & $0.6 \mathrm{Mc} \mathrm{IE}$ & 152.5 & 2.64 & 7 & 145 & 11.5 & 0.07 & 0.5 & 11.7 \\
\hline $9 / 16 / 2013$ & $19: 03: 31.9$ & 43.7938 & -110.8943 & $0.6 \mathrm{Mc}$ IE & 152.9 & 3.33 & 4 & 147 & 12.0 & 0.01 & 0.5 & 10.7 \\
\hline $9 / 17 / 2013$ & $02: 47: 54.6$ & 43.7663 & -110.8988 & $0.3 \mathrm{Mc}$ IE & 152.3 & 2.50 & 5 & 137 & 14.9 & 0.10 & 0.6 & 14.9 \\
\hline $9 / 17 / 2013$ & $06: 45: 45.6$ & 44.7192 & -111.5470 & 1.0 Mc IE & 154.6 & 3.77 & 4 & 165 & 9.5 & 0.15 & 2.5 & 5.1 \\
\hline $9 / 17 / 2013$ & $07: 48: 45.2$ & 42.7090 & -111.3127 & 1.0 Mc IE & 158.8 & 3.03 & 6 & 283 & 18.5 & 0.10 & 1.2 & 11.8 \\
\hline $9 / 17 / 2013$ & $08: 27: 11.3$ & 43.8023 & -110.9065 & 1.0 Mc IE & 152.1 & 3.42 & 8 & 109 & 10.8 & 0.09 & 0.8 & 8.3 \\
\hline $9 / 18 / 2013$ & 01:26:47.4 & 44.5905 & -112.1565 & 1.4 Mc IE & 116.0 & 13.94 & 11 & 105 & 18.9 & 0.12 & 0.6 & 1.6 \\
\hline $9 / 18 / 2013$ & $04: 35: 34.7$ & 43.7960 & -110.8332 & $0.3 \mathrm{Mc}$ IE & 157.9 & 4.86 & 4 & 233 & 14.1 & 0.05 & 2.7 & 12.6 \\
\hline $9 / 18 / 2013$ & $05: 35: 25.6$ & 43.7913 & -110.8468 & $0.3 \mathrm{Mc}$ IE & 156.7 & 2.49 & 6 & 227 & 13.9 & 0.22 & 2.3 & 22.0 \\
\hline $9 / 18 / 2013$ & $08: 37: 29.1$ & 43.7978 & -110.9002 & 1.1 Mc IE & 152.5 & 2.96 & 7 & 184 & 11.5 & 0.03 & 1.4 & 9.1 \\
\hline $9 / 18 / 2013$ & $08: 39: 32.3$ & 43.7823 & -110.8288 & $0.7 \mathrm{Mc}$ IE & 158.1 & 4.96 & 4 & 231 & 15.5 & 0.14 & 3.0 & 15.2 \\
\hline $9 / 18 / 2013$ & $16: 49: 55.5$ & 43.7300 & -110.8550 & $0.6 \mathrm{Mc}$ IE & 155.6 & 2.46 & 6 & 217 & 17.2 & 0.19 & 1.6 & 19.9 \\
\hline $9 / 18 / 2013$ & $19: 49: 29.7$ & 43.8708 & -111.0008 & $0.6 \mathrm{Mc}$ IE & 145.5 & 4.33 & 4 & 234 & 5.8 & 0.11 & 9.8 & 11.8 \\
\hline $9 / 18 / 2013$ & $23: 41: 48.4$ & 44.6018 & -112.6313 & 1.1 Mc IE & 106.6 & 17.08 & 6 & 128 & 18.8 & 0.06 & 0.7 & 1.1 \\
\hline $9 / 19 / 2013$ & $00: 46: 42.3$ & 43.7958 & -110.9045 & $0.5 \mathrm{Mc}$ IE & 152.2 & 3.66 & 5 & 142 & 11.6 & 0.05 & 0.6 & 9.3 \\
\hline 9/19/2013 & 05:04:50.2 & 43.8005 & -110.8967 & $0.9 \mathrm{Mc}$ IE & 152.8 & 2.38 & 10 & 122 & 11.3 & 0.08 & 0.7 & 10.7 \\
\hline
\end{tabular}


Table C-2. Continued.

\begin{tabular}{|c|c|c|c|c|c|c|c|c|c|c|c|c|}
\hline ORIGIN & TIME & LAT N & LONG W & MAG-TYP & DIST & Z & NO & GAP & DMIN & RMS & $\mathrm{ERH}$ & ERZ \\
\hline 9/19/2013 & $05: 10: 56.6$ & 43.7062 & -110.9132 & $0.7 \mathrm{Mc} \mathrm{IE}$ & 150.8 & 17.19 & 5 & 241 & 11.9 & 0.01 & 2.3 & 1.6 \\
\hline $9 / 19 / 2013$ & $11: 52: 56.9$ & 44.6102 & -112.0642 & 1.6 Mc IE & 121.3 & 0.32 & 5 & 160 & 26.3 & 0.02 & 1.0 & 2.5 \\
\hline $9 / 19 / 2013$ & $14: 56: 33.1$ & 42.6880 & -111.6312 & $1.4 \mathrm{Mc} \mathrm{IE}$ & 142.2 & 0.08 & 6 & 132 & 44.3 & 0.32 & 1.6 & 20.4 \\
\hline 9/19/2013 & $15: 00: 20.6$ & 43.3692 & -111.0617 & $0.2 \mathrm{Mc}$ IE & 142.6 & 5.25 & 5 & 273 & 16.2 & 0.09 & 3.3 & 13.7 \\
\hline $9 / 19 / 2013$ & $18: 25: 58.4$ & 43.5858 & -110.8525 & $0.8 \mathrm{Mc} \mathrm{IE}$ & 155.9 & 7.66 & 7 & 136 & 13.3 & 0.35 & 1.4 & 6.7 \\
\hline $9 / 19 / 2013$ & $18: 39: 11.5$ & 43.7973 & -110.9130 & $0.6 \mathrm{Mc} \mathrm{IE}$ & 151.5 & 2.52 & 5 & 142 & 11.3 & 0.04 & 0.8 & 12.0 \\
\hline $9 / 19 / 2013$ & $18: 57: 42.2$ & 43.7975 & -110.9123 & $0.5 \mathrm{Mc} \mathrm{IE}$ & 151.6 & 2.44 & 5 & 141 & 11.3 & 0.03 & 0.8 & 12.1 \\
\hline $9 / 20 / 2013$ & $00: 13: 14.7$ & 43.8245 & -111.0352 & $0.4 \mathrm{Mc} \mathrm{IE}$ & 142.1 & 4.52 & 4 & 225 & 11.1 & 0.04 & 6.4 & 11.3 \\
\hline $9 / 20 / 2013$ & $00: 56: 24.9$ & 43.7975 & -110.9057 & $0.6 \mathrm{Mc}$ IE & 152.1 & 2.75 & 7 & 143 & 11.4 & 0.05 & 0.5 & 10.8 \\
\hline $9 / 20 / 2013$ & $02: 51: 21.9$ & 43.7520 & -110.8938 & $0.5 \mathrm{Mc}$ IE & 152.6 & 8.30 & 6 & 148 & 16.6 & 0.13 & 1.1 & 4.6 \\
\hline $9 / 20 / 2013$ & 08:40:06.2 & 44.6135 & -112.0577 & $1.5 \mathrm{Mc} \mathrm{IE}$ & 121.9 & 5.01 & 8 & 114 & 26.8 & 0.16 & 0.9 & 18.0 \\
\hline $9 / 20 / 2013$ & $11: 20: 56.4$ & 42.9705 & -111.2707 & $0.4 \mathrm{Mc} \mathrm{IE}$ & 144.1 & 5.01 & 6 & 111 & 12.3 & 0.06 & 0.7 & 6.9 \\
\hline $9 / 20 / 2013$ & $17: 39: 16.1$ & 43.7942 & -110.8992 & $0.2 \mathrm{Mc}$ IE & 152.6 & 2.23 & 4 & 145 & 11.9 & 0.03 & 0.5 & 12.7 \\
\hline $9 / 20 / 2013$ & $18: 17: 23.5$ & 43.8078 & -110.9753 & $0.4 \mathrm{Mc} \mathrm{IE}$ & 146.6 & 2.09 & 4 & 183 & 10.3 & 0.03 & 12.4 & 12.8 \\
\hline $9 / 21 / 2013$ & $13: 13: 13.7$ & 43.7992 & -110.9080 & $0.7 \mathrm{Mc} \mathrm{IE}$ & 151.9 & 2.04 & 8 & 142 & 11.2 & 0.11 & 0.8 & 15.5 \\
\hline $9 / 21 / 2013$ & $16: 18: 49.4$ & 43.7990 & -110.9098 & $0.2 \mathrm{Mc}$ IE & 151.8 & 2.47 & 5 & 141 & 11.1 & 0.01 & 0.8 & 12.1 \\
\hline $9 / 21 / 2013$ & 19:01:04.5 & 43.7953 & -110.9032 & $0.5 \mathrm{Mc}$ IE & 152.3 & 2.50 & 6 & 143 & 11.7 & 0.08 & 0.6 & 13.0 \\
\hline $9 / 21 / 2013$ & $20: 23: 31.7$ & 43.8023 & -110.9128 & $0.0 \mathrm{Mc} \mathrm{IE}$ & 151.6 & 2.53 & 4 & 142 & 10.7 & 0.02 & 0.7 & 11.7 \\
\hline $9 / 22 / 2013$ & 03:38:47.8 & 42.9933 & -111.2550 & 1.0 Mc IE & 143.8 & 2.49 & 8 & 268 & 11.5 & 0.08 & 1.4 & 13.6 \\
\hline $9 / 22 / 2013$ & $03: 40: 11.2$ & 42.9518 & -111.3678 & $0.1 \mathrm{Mc} \mathrm{IE}$ & 138.6 & 2.31 & 6 & 127 & 4.7 & 0.15 & 1.7 & 17.5 \\
\hline $9 / 22 / 2013$ & $03: 43: 22.1$ & 42.9680 & -111.2627 & $0.4 \mathrm{Mc}$ IE & 144.8 & 6.83 & 5 & 112 & 12.9 & 0.06 & 1.1 & 5.8 \\
\hline $9 / 22 / 2013$ & 08:00:12.4 & 43.4840 & -110.9445 & $0.4 \mathrm{Mc} \mathrm{IE}$ & 149.6 & 3.23 & 5 & 174 & 0.8 & 0.02 & 8.9 & 1.6 \\
\hline $9 / 22 / 2013$ & $19: 28: 15.6$ & 44.6845 & -111.5730 & $0.8 \mathrm{Mc}$ IE & 150.3 & 0.03 & 4 & 204 & 8.9 & 0.13 & 12.5 & 10.7 \\
\hline $9 / 22 / 2013$ & $19: 33: 19.1$ & 44.6703 & -111.6618 & $0.5 \mathrm{Mc}$ IE & 144.6 & 4.55 & 4 & 146 & 6.6 & 0.25 & 16.3 & 15.6 \\
\hline $9 / 22 / 2013$ & $19: 41: 44.5$ & 43.3322 & -111.5178 & $0.8 \mathrm{Mc} \mathrm{IE}$ & 108.2 & 18.34 & 5 & 175 & 71.6 & 0.08 & 2.3 & 14.1 \\
\hline $9 / 22 / 2013$ & $20: 30: 27.1$ & 44.7213 & -111.5672 & 1.1 Mc IE & 153.8 & 4.78 & 6 & 233 & 7.9 & 0.11 & 2.5 & 1.4 \\
\hline $9 / 24 / 2013$ & $08: 17: 17.3$ & 43.8035 & -110.9008 & 1.3 Mc IE & 152.5 & 2.50 & 7 & 178 & 21.0 & 0.06 & 0.6 & 12.8 \\
\hline $9 / 24 / 2013$ & $10: 53: 20.9$ & 43.4012 & -110.8357 & $0.6 \mathrm{Mc}$ IE & 159.8 & 4.02 & 5 & 159 & 4.5 & 0.11 & 1.1 & 5.2 \\
\hline $9 / 25 / 2013$ & $05: 52: 45.3$ & 43.7977 & -110.9075 & $0.6 \mathrm{Mc}$ IE & 151.9 & 2.50 & 6 & 141 & 11.3 & 0.09 & 0.9 & 13.5 \\
\hline $9 / 26 / 2013$ & 01:16:12.7 & 44.2128 & -113.2202 & 1.3 Mc IE & 71.8 & 1.07 & 4 & 188 & 18.3 & 0.01 & 1.0 & 1.9 \\
\hline $9 / 26 / 2013$ & 01:52:56.1 & 43.7518 & -110.9065 & $0.4 \mathrm{Mc}$ IE & 151.6 & 12.87 & 4 & 133 & 15.9 & 0.00 & 0.7 & 3.4 \\
\hline $9 / 26 / 2013$ & $06: 07: 27.2$ & 44.6215 & -114.2600 & 1.8 Mc IE & 160.1 & 8.80 & 7 & 153 & 76.3 & 0.32 & 2.8 & 6.7 \\
\hline 9/26/2013 & $12: 17: 45.2$ & 43.7980 & -110.9023 & $0.8 \mathrm{Mc}$ IE & 152.4 & 2.49 & 8 & 145 & 11.4 & 0.09 & 0.6 & 12.3 \\
\hline $9 / 26 / 2013$ & $14: 17: 44.9$ & 43.7652 & -110.9087 & $0.0 \mathrm{Mc}$ IE & 151.5 & 12.38 & 4 & 136 & 14.9 & 0.01 & 0.6 & 3.5 \\
\hline $9 / 26 / 2013$ & $20: 49: 49.1$ & 43.2688 & -111.1593 & $0.9 \mathrm{Mc}$ IE & 138.0 & 13.73 & 8 & 208 & 27.0 & 0.08 & 0.9 & 1.4 \\
\hline $9 / 26 / 2013$ & $22: 08: 21.3$ & 42.8213 & -111.2107 & 1.7 Mc IE & 157.5 & 10.83 & 10 & 184 & 11.0 & 0.06 & 1.0 & 2.5 \\
\hline $9 / 26 / 2013$ & $22: 14: 37.9$ & 42.8122 & -111.1967 & $0.7 \mathrm{Mc}$ IE & 159.0 & 12.95 & 6 & 210 & 9.4 & 0.04 & 1.3 & 2.4 \\
\hline $9 / 27 / 2013$ & $00: 13: 07.2$ & 42.8287 & -111.2088 & 1.4 Mc IE & 157.1 & 4.55 & 8 & 177 & 11.3 & 0.12 & 1.0 & 8.8 \\
\hline 9/27/2013 & 01:14:35.8 & 43.5988 & -110.8417 & $0.9 \mathrm{Mc}$ IE & 156.7 & 4.88 & 5 & 195 & 14.9 & 0.05 & 2.3 & 11.9 \\
\hline $9 / 27 / 2013$ & $02: 23: 25.0$ & 43.8043 & -110.9157 & 1.0 Mc IE & 151.3 & 5.03 & 6 & 144 & 10.5 & 0.12 & 1.3 & 7.7 \\
\hline $9 / 27 / 2013$ & 04:40:39.1 & 43.4188 & -110.9587 & $0.3 \mathrm{Mc}$ IE & 149.6 & 7.60 & 7 & 223 & 8.0 & 0.09 & 2.0 & 1.0 \\
\hline $9 / 27 / 2013$ & 05:46:06.2 & 43.7972 & -110.8977 & $0.2 \mathrm{Mc} \mathrm{IE}$ & 152.7 & 2.72 & 5 & 146 & 11.6 & 0.02 & 0.7 & 11.5 \\
\hline $9 / 27 / 2013$ & $11: 20: 15.2$ & 43.7997 & -110.8988 & $0.6 \mathrm{Mc}$ IE & 152.7 & 4.03 & 6 & 147 & 11.3 & 0.03 & 0.5 & 6.0 \\
\hline $9 / 27 / 2013$ & $11: 53: 11.1$ & 43.8015 & -110.9740 & $0.0 \mathrm{Mc}$ IE & 146.7 & 2.49 & 4 & 180 & 11.0 & 0.29 & 27.0 & 24.4 \\
\hline $9 / 27 / 2013$ & 19:03:03.9 & 43.4448 & -111.1348 & $0.7 \mathrm{Mc}$ IE & 135.1 & 4.11 & 7 & 266 & 15.7 & 0.06 & 2.0 & 11.2 \\
\hline $9 / 27 / 2013$ & $19: 48: 49.9$ & 43.4408 & -111.1440 & $0.6 \mathrm{Mc}$ IE & 134.4 & 4.01 & 5 & 267 & 16.6 & 0.06 & 2.0 & 11.6 \\
\hline $9 / 27 / 2013$ & 23:01:10.9 & 42.8683 & -111.5007 & 1.1 Mc IE & 135.6 & 2.15 & 7 & 272 & 10.1 & 0.23 & 1.6 & 22.2 \\
\hline $9 / 28 / 2013$ & 07:06:30.1 & 43.8012 & -110.9017 & $0.8 \mathrm{Mc}$ IE & 152.4 & 2.05 & 9 & 123 & 11.1 & 0.07 & 0.6 & 13.9 \\
\hline $9 / 28 / 2013$ & $11: 43: 48.6$ & 43.9087 & -113.8000 & 2.2 ML IE & 86.7 & 1.77 & 25 & 234 & 28.0 & 0.08 & 0.6 & 0.7 \\
\hline $9 / 28 / 2013$ & $21: 39: 11.6$ & 44.3278 & -113.2213 & $0.9 \mathrm{Mc}$ IE & 83.2 & 5.80 & 4 & 124 & 14.8 & 0.01 & 0.9 & 1.2 \\
\hline 9/29/2013 & $23: 24: 15.7$ & 44.2890 & -113.1518 & $0.8 \mathrm{Mc}$ IE & 77.0 & 10.06 & 6 & 152 & 20.4 & 0.07 & 1.3 & 7.2 \\
\hline
\end{tabular}


Table C-2. Continued.

\begin{tabular}{|c|c|c|c|c|c|c|c|c|c|c|c|c|}
\hline ORIGIN & TIME & LAT N & LONG W & MAG-TYP & DIST & $z$ & NO & GAP & DMIN & RMS & $\mathrm{ERH}$ & ERZ \\
\hline $9 / 30 / 2013$ & 03:11:10.8 & 43.5893 & -110.9898 & $0.8 \mathrm{Mc}$ IE & 144.8 & 2.18 & 5 & 203 & 11.5 & 0.08 & 0.8 & 14.0 \\
\hline $9 / 30 / 2013$ & $08: 02: 38.2$ & 43.2187 & -111.0410 & $0.8 \mathrm{Mc} \mathrm{IE}$ & 148.9 & 13.08 & 6 & 193 & 22.2 & 0.09 & 1.2 & 4.3 \\
\hline $9 / 30 / 2013$ & 09:33:00.1 & 43.8502 & -110.9732 & $0.3 \mathrm{Mc} \mathrm{IE}$ & 147.4 & 2.80 & 4 & 196 & 5.9 & 0.01 & 0.8 & 9.4 \\
\hline $10 / 1 / 2013$ & $08: 44: 28.2$ & 43.2218 & -111.0443 & $0.8 \mathrm{Mc}$ IE & 148.5 & 9.44 & 9 & 191 & 22.1 & 0.10 & 0.8 & 3.2 \\
\hline $10 / 1 / 2013$ & 09:29:47.1 & 44.7405 & -111.5707 & 1.4 Mc IE & 155.2 & 6.95 & 6 & 251 & 7.6 & 0.00 & 2.0 & 1.9 \\
\hline $10 / 1 / 2013$ & $16: 48: 35.6$ & 43.3405 & -110.8685 & $0.4 \mathrm{Mc}$ IE & 158.6 & 6.34 & 5 & 310 & 2.8 & 0.08 & 11.4 & 4.5 \\
\hline $10 / 2 / 2013$ & $13: 21: 33.6$ & 42.6290 & -112.0005 & $2.3 \mathrm{Mc} \mathrm{IE}$ & 130.2 & 8.61 & 29 & 116 & 40.4 & 0.06 & 0.2 & 0.9 \\
\hline $10 / 2 / 2013$ & 15:01:30.9 & 44.3722 & -114.0238 & 1.3 Mc IE & 127.8 & 4.35 & 5 & 162 & 49.8 & 0.00 & 3.2 & 6.1 \\
\hline $10 / 4 / 2013$ & $03: 39: 24.0$ & 43.6620 & -110.9188 & $0.8 \mathrm{Mc} \mathrm{IE}$ & 150.3 & 2.67 & 7 & 105 & 9.1 & 0.08 & 0.7 & 11.1 \\
\hline $10 / 8 / 2013$ & 09:23:01.6 & 44.6375 & -112.1395 & $0.9 \mathrm{Mc} \mathrm{IE}$ & 121.3 & 4.01 & 4 & 227 & 20.8 & 0.00 & 2.7 & 2.4 \\
\hline $10 / 8 / 2013$ & $21: 17: 29.4$ & 42.8237 & -111.3795 & $0.7 \mathrm{Mc} \mathrm{IE}$ & 146.4 & 10.29 & 4 & 256 & 23.7 & 0.00 & 2.4 & 3.6 \\
\hline $10 / 9 / 2013$ & $00: 24: 03.9$ & 43.0392 & -111.2987 & $0.5 \mathrm{Mc} \mathrm{IE}$ & 138.2 & 5.00 & 4 & 177 & 6.1 & 0.05 & 4.6 & 8.8 \\
\hline $10 / 9 / 2013$ & 05:35:01.3 & 44.6375 & -113.1268 & 1.2 Mc IE & 113.2 & 5.00 & 4 & 194 & 30.5 & 0.08 & 4.3 & 13.1 \\
\hline $10 / 10 / 2013$ & $06: 32: 28.8$ & 43.1613 & -111.3655 & $0.5 \mathrm{Mc} \mathrm{IE}$ & 127.0 & 13.88 & 4 & 131 & 12.0 & 0.11 & 2.2 & 3.7 \\
\hline $10 / 10 / 2013$ & $14: 57: 04.2$ & 42.7235 & -111.6067 & $0.8 \mathrm{Mc} \mathrm{IE}$ & 140.6 & 5.21 & 6 & 256 & 41.4 & 0.28 & 3.6 & 22.7 \\
\hline $10 / 11 / 2013$ & $11: 12: 12.8$ & 43.3847 & -111.1248 & $0.2 \mathrm{Mc} \mathrm{IE}$ & 137.2 & 5.54 & 5 & 279 & 18.3 & 0.31 & 5.6 & 26.9 \\
\hline $10 / 11 / 2013$ & $17: 13: 50.8$ & 42.9800 & -111.4107 & $0.6 \mathrm{Mc} \mathrm{IE}$ & 133.9 & 2.44 & 4 & 190 & 4.7 & 0.33 & 21.1 & 23.7 \\
\hline $10 / 12 / 2013$ & $20: 14: 09.2$ & 43.5352 & -110.9698 & $0.4 \mathrm{Mc} \mathrm{IE}$ & 146.9 & 8.77 & 6 & 177 & 5.2 & 0.02 & 0.6 & 1.8 \\
\hline $10 / 14 / 2013$ & 07:14:38.9 & 44.2823 & -111.4807 & 1.0 Mc IE & 125.9 & 5.00 & 6 & 321 & 25.9 & 0.23 & 2.9 & 20.1 \\
\hline $10 / 14 / 2013$ & $15: 22: 42.3$ & 42.6557 & -111.6630 & 1.4 Mc IE & 143.3 & 5.00 & 6 & 136 & 37.1 & 0.05 & 1.0 & 12.4 \\
\hline $10 / 14 / 2013$ & $22: 41: 29.1$ & 43.8218 & -111.0277 & $0.0 \mathrm{Mc} \mathrm{IE}$ & 142.6 & 4.34 & 4 & 221 & 11.0 & 0.02 & 6.4 & 10.9 \\
\hline $10 / 16 / 2013$ & 03:11:15.0 & 44.7212 & -111.9138 & 1.3 Mc IE & 137.9 & 11.40 & 6 & 167 & 19.7 & 0.01 & 1.6 & 3.2 \\
\hline $10 / 16 / 2013$ & $10: 21: 35.8$ & 43.1882 & -110.9765 & 1.2 Mc IE & 155.0 & 5.03 & 5 & 324 & 21.8 & 0.02 & 1.6 & 11.4 \\
\hline $10 / 16 / 2013$ & $10: 28: 25.2$ & 43.1483 & -110.9243 & $0.8 \mathrm{Mc}$ IE & 160.5 & 4.44 & 6 & 339 & 24.5 & 0.11 & 3.8 & 13.8 \\
\hline $10 / 16 / 2013$ & $16: 19: 14.8$ & 42.9747 & -111.3302 & 1.3 Mc IE & 139.7 & 8.50 & 8 & 123 & 8.5 & 0.07 & 0.8 & 1.3 \\
\hline $10 / 16 / 2013$ & $17: 30: 15.4$ & 43.8035 & -110.9327 & $0.6 \mathrm{Mc} \mathrm{IE}$ & 150.0 & 2.61 & 5 & 185 & 10.4 & 0.09 & 2.1 & 11.3 \\
\hline $10 / 16 / 2013$ & $22: 24: 23.5$ & 43.1828 & -110.9012 & $0.7 \mathrm{Mc} \mathrm{IE}$ & 160.9 & 18.52 & 6 & 224 & 20.3 & 0.11 & 1.5 & 3.1 \\
\hline $10 / 16 / 2013$ & $23: 55: 47.7$ & 43.1445 & -111.0363 & $0.6 \mathrm{Mc} \mathrm{IE}$ & 152.2 & 5.09 & 6 & 329 & 28.5 & 0.18 & 2.8 & 19.4 \\
\hline $10 / 18 / 2013$ & 02:05:11.7 & 44.8512 & -113.8650 & $2.0 \mathrm{Mc} \mathrm{IE}$ & 159.1 & 12.30 & 7 & 257 & 70.3 & 0.14 & 2.5 & 1.3 \\
\hline $10 / 18 / 2013$ & $16: 39: 57.1$ & 43.4222 & -110.9430 & $0.5 \mathrm{Mc} \mathrm{IE}$ & 150.8 & 8.70 & 8 & 214 & 7.6 & 0.07 & 0.6 & 0.9 \\
\hline $10 / 18 / 2013$ & $23: 39: 43.9$ & 43.4623 & -111.0553 & 2.0 ML IE & 141.1 & 10.46 & 12 & 143 & 9.0 & 0.06 & 0.5 & 1.3 \\
\hline $10 / 18 / 2013$ & $23: 40: 20.9$ & 43.4480 & -111.1010 & $0.8 \mathrm{Mc} \mathrm{IE}$ & 137.7 & 11.63 & 8 & 168 & 13.0 & 0.11 & 0.7 & 2.4 \\
\hline $10 / 19 / 2013$ & $00: 05: 51.5$ & 43.4523 & -111.0928 & 3.8 Mw US & 138.3 & 10.77 & 13 & 147 & 12.2 & 0.06 & 0.5 & 1.2 \\
\hline $10 / 19 / 2013$ & $00: 14: 27.7$ & 43.5490 & -110.7992 & $0.1 \mathrm{Mc}$ IE & 160.5 & 5.72 & 6 & 253 & 13.9 & 0.14 & 5.1 & 16.0 \\
\hline $10 / 19 / 2013$ & $00: 14: 47.2$ & 43.5617 & -110.8303 & 0.0 NoMag & 157.9 & 4.89 & 6 & 246 & 12.6 & 0.01 & 3.5 & 12.0 \\
\hline $10 / 19 / 2013$ & $00: 27: 16.5$ & 43.4898 & -110.9638 & $0.1 \mathrm{Mc}$ IE & 148.0 & 17.82 & 4 & 256 & 1.1 & 0.03 & 12.7 & 1.5 \\
\hline $10 / 19 / 2013$ & $00: 30: 06.9$ & 43.4415 & -111.0820 & 1.2 Mc IE & 139.3 & 7.84 & 7 & 143 & 11.9 & 0.07 & 0.6 & 2.9 \\
\hline $10 / 19 / 2013$ & 00:30:07.1 & 43.5483 & -110.7993 & 1.1 Mc IE & 160.5 & 5.79 & 6 & 253 & 13.8 & 0.21 & 6.5 & 19.8 \\
\hline $10 / 19 / 2013$ & $00: 51: 06.5$ & 43.5650 & -110.7942 & $0.1 \mathrm{Mc} \mathrm{IE}$ & 160.8 & 5.40 & 6 & 258 & 15.1 & 0.25 & 6.2 & 23.0 \\
\hline $10 / 19 / 2013$ & $00: 57: 53.6$ & 43.4465 & -111.1493 & $0.5 \mathrm{Mc} \mathrm{IE}$ & 133.9 & 5.05 & 5 & 273 & 16.8 & 0.05 & 2.4 & 12.3 \\
\hline $10 / 19 / 2013$ & 01:03:07.5 & 43.4380 & -111.1372 & $0.6 \mathrm{Mc} \mathrm{IE}$ & 135.0 & 5.00 & 7 & 268 & 16.2 & 0.18 & 4.1 & 15.3 \\
\hline $10 / 19 / 2013$ & 01:05:56.9 & 43.4437 & -111.0932 & $0.3 \mathrm{Mc} \mathrm{IE}$ & 138.4 & 10.72 & 9 & 259 & 12.6 & 0.11 & 1.0 & 1.5 \\
\hline $10 / 19 / 2013$ & $01: 28: 24.6$ & 43.4455 & -111.1148 & 1.1 Mc IE & 136.7 & 10.13 & 7 & 306 & 14.2 & 0.08 & 1.8 & 2.0 \\
\hline $10 / 19 / 2013$ & 01:43:50.2 & 43.4437 & -111.0930 & $0.5 \mathrm{Mc} \mathrm{IE}$ & 138.4 & 11.32 & 5 & 308 & 12.6 & 0.01 & 1.2 & 1.5 \\
\hline $10 / 19 / 2013$ & 02:00:40.1 & 43.4378 & -111.1373 & $0.8 \mathrm{Mc} \mathrm{IE}$ & 135.0 & 4.30 & 5 & 313 & 16.2 & 0.02 & 1.6 & 7.6 \\
\hline $10 / 19 / 2013$ & $02: 07: 57.5$ & 43.4475 & -111.0885 & $0.7 \mathrm{Mc} \mathrm{IE}$ & 138.7 & 11.68 & 8 & 307 & 12.1 & 0.03 & 1.1 & 1.2 \\
\hline $10 / 19 / 2013$ & 02:29:17.9 & 43.4490 & -111.0873 & $0.6 \mathrm{Mc} \mathrm{IE}$ & 138.8 & 11.67 & 7 & 306 & 12.0 & 0.03 & 2.4 & 1.9 \\
\hline $10 / 19 / 2013$ & $02: 43: 06.3$ & 43.4435 & -111.0968 & $0.7 \mathrm{Mc} \mathrm{IE}$ & 138.1 & 10.86 & 7 & 308 & 12.9 & 0.01 & 2.2 & 2.4 \\
\hline $10 / 19 / 2013$ & 03:07:07.4 & 43.4685 & -111.0855 & $0.5 \mathrm{Mc} \mathrm{IE}$ & 138.6 & 2.47 & 5 & 296 & 11.2 & 0.15 & 1.7 & 15.8 \\
\hline $10 / 19 / 2013$ & $03: 13: 14.3$ & 43.5373 & -111.2280 & $0.8 \mathrm{Mc}$ IE & 126.1 & 4.82 & 5 & 307 & 19.7 & 0.19 & 3.1 & 15.8 \\
\hline $10 / 19 / 2013$ & 03:39:19.8 & 43.4455 & -111.1185 & 1.0 Mc IE & 136.4 & 8.89 & 8 & 307 & 14.5 & 0.08 & 1.7 & 2.4 \\
\hline
\end{tabular}


Table C-2. Continued.

\begin{tabular}{|c|c|c|c|c|c|c|c|c|c|c|c|c|}
\hline ORIGIN & TIME & LAT N & LONG W & MAG-TYP & DIST & $z$ & NO & GAP & DMIN & RMS & $\mathrm{ERH}$ & ERZ \\
\hline $10 / 19 / 2013$ & $03: 51: 13.5$ & 43.4225 & -111.1105 & $0.3 \mathrm{Mc}$ IE & 137.5 & 5.95 & 5 & 315 & 15.0 & 0.03 & 3.2 & 8.5 \\
\hline $10 / 19 / 2013$ & 04:00:40.1 & 43.4253 & -111.0790 & $0.5 \mathrm{Mc} \mathrm{IE}$ & 139.9 & 11.72 & 5 & 309 & 12.6 & 0.03 & 1.2 & 1.5 \\
\hline $10 / 19 / 2013$ & $04: 12: 43.3$ & 43.4497 & -111.0882 & $0.5 \mathrm{Mc} \mathrm{IE}$ & 138.7 & 11.83 & 6 & 306 & 12.0 & 0.03 & 2.3 & 2.1 \\
\hline 10/19/2013 & 05:57:59.0 & 43.4425 & -111.0943 & $0.3 \mathrm{Mc}$ IE & 138.3 & 11.48 & 5 & 309 & 12.8 & 0.02 & 1.2 & 1.5 \\
\hline $10 / 19 / 2013$ & $06: 53: 28.8$ & 43.4420 & -111.1415 & $0.4 \mathrm{Mc} \mathrm{IE}$ & 134.6 & 3.58 & 6 & 272 & 16.3 & 0.06 & 1.3 & 9.7 \\
\hline 10/19/2013 & 08:04:10.7 & 42.9343 & -111.0603 & 0.0 NoMag & 160.8 & 1.07 & 6 & 185 & 19.1 & 0.23 & 1.8 & 9.7 \\
\hline 10/19/2013 & $09: 41: 41.5$ & 42.9312 & -111.0623 & $0.3 \mathrm{Mc}$ IE & 160.9 & 5.05 & 5 & 164 & 18.7 & 0.08 & 1.3 & 11.4 \\
\hline $10 / 19 / 2013$ & $10: 30: 44.2$ & 43.4315 & -111.1430 & $0.9 \mathrm{Mc} \mathrm{IE}$ & 134.7 & 3.53 & 5 & 270 & 16.9 & 0.04 & 3.1 & 10.1 \\
\hline 10/19/2013 & $10: 45: 24.2$ & 43.4402 & -111.1477 & $0.3 \mathrm{Mc} \mathrm{IE}$ & 134.1 & 5.05 & 5 & 274 & 16.9 & 0.04 & 2.3 & 12.2 \\
\hline 10/19/2013 & $11: 05: 03.0$ & 43.4297 & -111.1723 & $0.8 \mathrm{Mc} \mathrm{IE}$ & 132.4 & 4.56 & 5 & 274 & 19.2 & 0.10 & 4.0 & 10.0 \\
\hline 10/19/2013 & $11: 54: 08.2$ & 43.4370 & -111.1445 & $0.5 \mathrm{Mc} \mathrm{IE}$ & 134.5 & 5.05 & 5 & 274 & 16.8 & 0.05 & 2.3 & 12.2 \\
\hline 10/19/2013 & $12: 01: 10.1$ & 42.9672 & -111.0955 & $0.9 \mathrm{Mc} \mathrm{IE}$ & 156.5 & 5.04 & 5 & 266 & 24.4 & 0.25 & 2.6 & 18.1 \\
\hline 10/19/2013 & $20: 06: 23.4$ & 43.5150 & -110.9312 & $0.7 \mathrm{Mc}$ IE & 150.2 & 16.17 & 6 & 121 & 3.2 & 0.14 & 1.6 & 1.5 \\
\hline 10/19/2013 & $22: 06: 29.2$ & 43.5553 & -110.7932 & $0.7 \mathrm{Mc}$ IE & 160.9 & 5.47 & 6 & 256 & 14.7 & 0.26 & 6.7 & 23.7 \\
\hline 10/19/2013 & $23: 52: 57.7$ & 43.4655 & -111.1110 & $0.4 \mathrm{Mc} \mathrm{IE}$ & 136.6 & 11.61 & 5 & 310 & 13.3 & 0.02 & 1.2 & 1.5 \\
\hline $10 / 20 / 2013$ & 03:18:20.1 & 43.4827 & -110.9603 & $0.6 \mathrm{Mc}$ IE & 148.3 & 17.36 & 4 & 300 & 1.1 & 0.02 & 12.6 & 1.3 \\
\hline $10 / 20 / 2013$ & $04: 27: 56.8$ & 43.5600 & -110.8203 & $0.1 \mathrm{Mc} \mathrm{IE}$ & 158.7 & 5.36 & 6 & 249 & 13.1 & 0.14 & 5.0 & 16.2 \\
\hline $10 / 20 / 2013$ & $09: 26: 45.7$ & 44.5163 & -112.8447 & 1.1 Mc IE & 96.5 & 4.46 & 6 & 230 & 22.2 & 0.02 & 1.9 & 2.2 \\
\hline $10 / 20 / 2013$ & $11: 34: 00.6$ & 43.4390 & -111.1470 & $0.7 \mathrm{Mc} \mathrm{IE}$ & 134.2 & 5.06 & 5 & 274 & 16.9 & 0.06 & 2.4 & 12.7 \\
\hline $10 / 20 / 2013$ & $11: 36: 08.5$ & 43.4482 & -111.1185 & $0.7 \mathrm{Mc}$ IE & 136.3 & 2.49 & 7 & 266 & 14.4 & 0.15 & 1.4 & 15.9 \\
\hline $10 / 20 / 2013$ & $12: 46: 11.5$ & 43.4465 & -111.1260 & $0.6 \mathrm{Mc} \mathrm{IE}$ & 135.7 & 10.31 & 8 & 264 & 15.0 & 0.06 & 1.5 & 2.4 \\
\hline $10 / 20 / 2013$ & $13: 51: 49.9$ & 43.4380 & -111.1468 & $0.7 \mathrm{Mc} \mathrm{IE}$ & 134.3 & 5.47 & 5 & 274 & 16.9 & 0.07 & 2.8 & 12.7 \\
\hline $10 / 20 / 2013$ & $15: 08: 03.8$ & 43.4638 & -111.0715 & $0.7 \mathrm{Mc} \mathrm{IE}$ & 139.8 & 2.62 & 6 & 250 & 10.2 & 0.21 & 2.9 & 17.5 \\
\hline $10 / 20 / 2013$ & $15: 34: 36.4$ & 42.9345 & -111.0660 & $0.7 \mathrm{Mc} \mathrm{IE}$ & 160.4 & 2.30 & 6 & 169 & 19.0 & 0.15 & 1.3 & 17.8 \\
\hline $10 / 20 / 2013$ & $17: 55: 17.6$ & 43.5997 & -111.0428 & $0.6 \mathrm{Mc} \mathrm{IE}$ & 140.5 & 21.08 & 4 & 359 & 14.3 & 0.06 & 13.6 & 1.3 \\
\hline $10 / 20 / 2013$ & $19: 52: 58.9$ & 42.8148 & -111.2962 & 1.0 Mc IE & 152.3 & 2.48 & 6 & 210 & 16.9 & 0.13 & 1.1 & 16.0 \\
\hline $10 / 22 / 2013$ & $05: 21: 20.0$ & 44.3965 & -113.2055 & $0.6 \mathrm{Mc} \mathrm{IE}$ & 89.7 & 0.93 & 4 & 171 & 18.5 & 0.00 & 1.6 & 2.3 \\
\hline $10 / 22 / 2013$ & $22: 19: 52.1$ & 44.3895 & -111.3620 & 1.1 Mc IE & 140.5 & 25.58 & 3 & 359 & 26.4 & 0.11 & 15.7 & 1.8 \\
\hline $10 / 23 / 2013$ & 01:50:30.9 & 44.3337 & -112.7957 & $0.7 \mathrm{Mc} \mathrm{IE}$ & 76.1 & 9.83 & 6 & 121 & 11.6 & 0.09 & 0.9 & 2.6 \\
\hline $10 / 23 / 2013$ & $07: 42: 50.5$ & 43.6130 & -111.0717 & $0.7 \mathrm{Mc} \mathrm{IE}$ & 138.1 & 12.01 & 7 & 206 & 4.6 & 0.13 & 3.6 & 0.9 \\
\hline $10 / 23 / 2013$ & $12: 38: 58.8$ & 42.9348 & -111.0823 & 2.2 Mc IE & 159.2 & 4.12 & 15 & 169 & 26.9 & 0.21 & 2.1 & 9.1 \\
\hline $10 / 23 / 2013$ & $16: 06: 17.8$ & 43.4330 & -110.8817 & $0.4 \mathrm{Mc} \mathrm{IE}$ & 155.5 & 12.68 & 7 & 157 & 8.2 & 0.07 & 0.5 & 1.0 \\
\hline $10 / 23 / 2013$ & $19: 35: 11.3$ & 44.4525 & -111.1125 & $0.9 \mathrm{Mc}$ IE & 160.8 & 4.89 & 4 & 310 & 29.7 & 0.04 & 3.1 & 12.4 \\
\hline $10 / 24 / 2013$ & $11: 53: 26.5$ & 42.9363 & -111.0598 & 1.6 Mc IE & 160.8 & 4.56 & 6 & 245 & 28.5 & 0.05 & 2.2 & 10.0 \\
\hline $10 / 24 / 2013$ & $11: 57: 34.8$ & 42.9470 & -111.0708 & 1.1 Mc IE & 159.4 & 4.93 & 6 & 275 & 27.2 & 0.06 & 1.5 & 12.0 \\
\hline $10 / 24 / 2013$ & $13: 48: 54.3$ & 43.5517 & -110.7960 & $0.1 \mathrm{Mc}$ IE & 160.7 & 5.36 & 5 & 255 & 14.2 & 0.21 & 5.8 & 20.4 \\
\hline $10 / 24 / 2013$ & $21: 15: 40.1$ & 42.7835 & -111.5443 & 0.0 NoMag & 139.3 & 2.50 & 5 & 240 & 19.9 & 0.08 & 1.8 & 13.6 \\
\hline $10 / 25 / 2013$ & $06: 53: 05.4$ & 42.9303 & -111.0740 & $0.6 \mathrm{Mc} \mathrm{IE}$ & 160.1 & 4.98 & 4 & 167 & 18.5 & 0.04 & 1.0 & 10.4 \\
\hline $10 / 25 / 2013$ & $11: 36: 52.9$ & 43.5353 & -110.8113 & $0.0 \mathrm{Mc} \mathrm{IE}$ & 159.7 & 5.89 & 5 & 246 & 12.3 & 0.15 & 6.3 & 16.6 \\
\hline $10 / 25 / 2013$ & $13: 16: 33.5$ & 43.4958 & -110.9687 & $0.3 \mathrm{Mc} \mathrm{IE}$ & 147.5 & 17.27 & 4 & 231 & 1.6 & 0.01 & 12.5 & 1.4 \\
\hline $10 / 25 / 2013$ & $20: 23: 00.4$ & 42.7762 & -111.5748 & 1.1 Mc IE & 138.1 & 4.66 & 5 & 244 & 21.9 & 0.11 & 2.4 & 13.5 \\
\hline $10 / 26 / 2013$ & $10: 43: 45.2$ & 44.7568 & -111.5403 & $1.9 \mathrm{Mc} \mathrm{IE}$ & 158.2 & 9.25 & 10 & 261 & 10.4 & 0.16 & 3.0 & 1.9 \\
\hline $10 / 26 / 2013$ & $21: 42: 46.9$ & 44.6877 & -111.5710 & 1.1 Mc IE & 150.7 & 4.72 & 5 & 206 & 8.8 & 0.09 & 6.8 & 10.5 \\
\hline $10 / 26 / 2013$ & 23:06:06.8 & 43.4398 & -111.1445 & 1.1 Mc IE & 134.4 & 2.52 & 6 & 274 & 16.6 & 0.03 & 0.9 & 12.7 \\
\hline $10 / 27 / 2013$ & 02:13:05.4 & 43.5068 & -110.9355 & $0.6 \mathrm{Mc} \mathrm{IE}$ & 150.0 & 1.57 & 5 & 214 & 2.2 & 0.09 & 7.4 & 9.2 \\
\hline $10 / 27 / 2013$ & $12: 51: 56.3$ & 43.5607 & -110.8077 & $0.3 \mathrm{Mc} \mathrm{IE}$ & 159.7 & 4.96 & 5 & 253 & 14.0 & 0.08 & 3.5 & 13.5 \\
\hline $10 / 27 / 2013$ & $12: 57: 47.1$ & 43.5543 & -110.8095 & $0.5 \mathrm{Mc}$ IE & 159.6 & 5.09 & 6 & 251 & 13.5 & 0.13 & 4.5 & 16.0 \\
\hline $10 / 28 / 2013$ & $08: 21: 46.5$ & 43.5627 & -110.8040 & $0.3 \mathrm{Mc} \mathrm{IE}$ & 160.0 & 5.11 & 5 & 254 & 14.3 & 0.11 & 3.9 & 15.0 \\
\hline $10 / 28 / 2013$ & $10: 44: 14.0$ & 43.2007 & -111.4160 & 1.7 Mc IE & 121.4 & 2.47 & 11 & 225 & 16.8 & 0.11 & 1.3 & 14.6 \\
\hline $10 / 28 / 2013$ & $12: 34: 39.7$ & 43.4558 & -111.0875 & $0.2 \mathrm{Mc}$ IE & 138.6 & 5.47 & 4 & 255 & 11.7 & 0.12 & 4.0 & 12.3 \\
\hline $10 / 28 / 2013$ & $16: 19: 56.0$ & 44.5027 & -112.9995 & $0.6 \mathrm{Mc}$ IE & 96.4 & 6.06 & 5 & 141 & 19.8 & 0.07 & 1.0 & 2.4 \\
\hline
\end{tabular}


Table C-2. Continued.

\begin{tabular}{|c|c|c|c|c|c|c|c|c|c|c|c|c|}
\hline ORIGIN & TIME & LAT N & LONG W & MAG-TYP & DIST & Z & NO & GAP & DMIN & RMS & ERH & ERZ \\
\hline $10 / 29 / 2013$ & $10: 42: 30.2$ & 42.9517 & -111.0678 & $0.4 \mathrm{Mc}$ IE & 159.3 & 4.92 & 5 & 275 & 27.2 & 0.01 & 1.3 & 11.7 \\
\hline $10 / 29 / 2013$ & $11: 58: 42.9$ & 43.4042 & -111.1472 & $0.8 \mathrm{Mc} \mathrm{IE}$ & 135.0 & 5.31 & 7 & 280 & 18.6 & 0.07 & 2.7 & 12.5 \\
\hline $10 / 29 / 2013$ & $21: 15: 50.1$ & 42.7063 & -111.7642 & 1.2 Mc IE & 133.7 & 4.97 & 7 & 317 & 38.0 & 0.19 & 13.9 & 16.0 \\
\hline $10 / 30 / 2013$ & $21: 20: 02.2$ & 42.7128 & -111.6653 & $0.6 \mathrm{Mc}$ IE & 138.3 & 5.05 & 5 & 310 & 32.0 & 0.19 & 3.6 & 17.9 \\
\hline $10 / 31 / 2013$ & $16: 13: 53.1$ & 43.4427 & -111.1392 & $0.4 \mathrm{Mc} \mathrm{IE}$ & 134.8 & 5.07 & 5 & 272 & 16.1 & 0.06 & 2.5 & 12.4 \\
\hline $11 / 1 / 2013$ & 08:38:10.8 & 43.5410 & -110.7970 & $0.3 \mathrm{Mc} \mathrm{IE}$ & 160.8 & 5.10 & 6 & 252 & 13.7 & 0.21 & 5.7 & 20.9 \\
\hline $11 / 1 / 2013$ & $22: 39: 14.4$ & 43.4480 & -111.1128 & 1.0 Mc IE & 136.8 & 8.46 & 8 & 178 & 13.9 & 0.11 & 2.0 & 4.6 \\
\hline $11 / 2 / 2013$ & $04: 37: 27.7$ & 42.6540 & -111.4105 & 1.1 Mc IE & 157.2 & 11.98 & 7 & 225 & 28.3 & 0.11 & 1.3 & 0.9 \\
\hline $11 / 2 / 2013$ & $11: 24: 21.6$ & 43.7242 & -111.0292 & $0.2 \mathrm{Mc} \mathrm{IE}$ & 141.6 & 2.00 & 6 & 202 & 9.6 & 0.16 & 1.1 & 18.5 \\
\hline $11 / 3 / 2013$ & $13: 32: 52.4$ & 44.7087 & -111.6842 & 1.2 Mc IE & 146.9 & 15.20 & 8 & 161 & 2.8 & 0.07 & 1.0 & 0.6 \\
\hline $11 / 3 / 2013$ & $15: 56: 36.4$ & 43.7342 & -110.8682 & $0.7 \mathrm{Mc} \mathrm{IE}$ & 154.6 & 4.81 & 4 & 251 & 16.7 & 0.07 & 3.8 & 13.2 \\
\hline $11 / 4 / 2013$ & 01:32:39.1 & 44.6503 & -112.3673 & 1.8 Mc IE & 116.1 & 5.02 & 6 & 142 & 34.6 & 0.07 & 0.7 & 13.7 \\
\hline $11 / 4 / 2013$ & 03:04:44.0 & 44.5978 & -113.5880 & 1.0 Mc IE & 123.5 & 5.00 & 5 & 255 & 35.1 & 0.10 & 4.8 & 14.9 \\
\hline $11 / 4 / 2013$ & 10:01:18.6 & 44.6222 & -112.3683 & $0.9 \mathrm{Mc} \mathrm{IE}$ & 113.1 & 3.11 & 6 & 218 & 3.8 & 0.08 & 1.6 & 0.7 \\
\hline $11 / 4 / 2013$ & $10: 21: 33.5$ & 44.6282 & -111.5793 & 1.2 Mc IE & 145.3 & 4.73 & 5 & 177 & 13.2 & 0.25 & 17.0 & 15.8 \\
\hline $11 / 4 / 2013$ & $11: 46: 14.5$ & 43.1847 & -110.9380 & 2.1 Mc IE & 158.1 & 9.66 & 17 & 167 & 20.9 & 0.06 & 0.7 & 1.2 \\
\hline $11 / 4 / 2013$ & $15: 14: 32.6$ & 44.6880 & -111.4278 & $0.9 \mathrm{Mc} \mathrm{IE}$ & 158.3 & 4.90 & 5 & 214 & 19.4 & 0.23 & 9.1 & 20.1 \\
\hline $11 / 5 / 2013$ & $00: 20: 58.8$ & 44.6802 & -111.5173 & 1.8 Mc IE & 152.9 & 0.05 & 11 & 215 & 13.0 & 0.29 & 6.2 & 11.6 \\
\hline $11 / 5 / 2013$ & $06: 45: 31.3$ & 43.0043 & -111.5715 & $0.7 \mathrm{Mc} \mathrm{IE}$ & 121.7 & 6.13 & 5 & 263 & 14.3 & 0.04 & 3.7 & 3.0 \\
\hline $11 / 6 / 2013$ & $04: 18: 54.3$ & 44.6310 & -111.8452 & $0.8 \mathrm{Mc} \mathrm{IE}$ & 132.4 & 3.63 & 4 & 274 & 18.0 & 0.21 & 18.3 & 6.3 \\
\hline $11 / 6 / 2013$ & $04: 36: 48.7$ & 44.4708 & -113.8875 & 1.2 Mc IE & 127.1 & 5.00 & 4 & 324 & 42.3 & 0.29 & 23.5 & 27.0 \\
\hline $11 / 6 / 2013$ & $05: 04: 25.3$ & 43.1705 & -110.9617 & $0.5 \mathrm{Mc} \mathrm{IE}$ & 156.8 & 5.03 & 5 & 248 & 35.5 & 0.04 & 2.2 & 11.5 \\
\hline $11 / 6 / 2013$ & $09: 25: 13.8$ & 43.4348 & -111.1440 & $0.5 \mathrm{Mc} \mathrm{IE}$ & 134.6 & 4.81 & 6 & 274 & 16.8 & 0.05 & 2.2 & 12.5 \\
\hline $11 / 6 / 2013$ & $13: 56: 14.1$ & 44.7320 & -112.3958 & 1.1 Mc IE & 124.3 & 12.93 & 4 & 235 & 15.4 & 0.00 & 2.9 & 1.8 \\
\hline $11 / 6 / 2013$ & $18: 45: 01.0$ & 43.4488 & -111.1140 & $0.2 \mathrm{Mc} \mathrm{IE}$ & 136.7 & 5.14 & 5 & 264 & 14.0 & 0.07 & 2.9 & 12.1 \\
\hline $11 / 7 / 2013$ & $05: 23: 10.5$ & 44.6520 & -112.6340 & 1.4 Mc IE & 112.1 & 8.18 & 6 & 172 & 20.1 & 0.24 & 3.1 & 2.8 \\
\hline $11 / 7 / 2013$ & $07: 23: 15.1$ & 44.5423 & -114.0228 & 1.3 Mc IE & 140.4 & 4.90 & 6 & 278 & 55.5 & 0.22 & 3.2 & 8.4 \\
\hline $11 / 7 / 2013$ & $08: 07: 37.7$ & 43.4305 & -111.1277 & $0.6 \mathrm{Mc} \mathrm{IE}$ & 135.9 & 5.10 & 5 & 271 & 15.8 & 0.06 & 2.6 & 12.4 \\
\hline $11 / 7 / 2013$ & $10: 44: 05.8$ & 42.8937 & -111.3005 & 1.0 Mc IE & 146.8 & 2.36 & 9 & 213 & 18.6 & 0.12 & 1.7 & 15.5 \\
\hline $11 / 7 / 2013$ & 13:01:08.8 & 42.8805 & -111.3217 & $0.6 \mathrm{Mc}$ IE & 146.2 & 4.89 & 4 & 224 & 19.6 & 0.08 & 2.7 & 10.6 \\
\hline $11 / 8 / 2013$ & $22: 25: 14.1$ & 44.7210 & -111.5433 & $0.9 \mathrm{Mc} \mathrm{IE}$ & 154.9 & 1.52 & 4 & 236 & 9.7 & 0.17 & 18.2 & 6.0 \\
\hline $11 / 8 / 2013$ & $23: 46: 52.8$ & 44.7118 & -111.5922 & 1.2 Mc IE & 151.7 & 3.81 & 4 & 221 & 6.2 & 0.00 & 4.3 & 4.4 \\
\hline $11 / 9 / 2013$ & 03:03:30.6 & 44.1955 & -110.9860 & $0.9 \mathrm{Mc} \mathrm{IE}$ & 156.5 & 13.28 & 6 & 210 & 15.7 & 0.01 & 0.7 & 2.2 \\
\hline $11 / 9 / 2013$ & $21: 36: 59.4$ & 43.1445 & -110.9672 & $0.7 \mathrm{Mc} \mathrm{IE}$ & 157.4 & 2.42 & 7 & 174 & 26.0 & 0.19 & 2.2 & 19.7 \\
\hline $11 / 11 / 2013$ & $06: 44: 58.8$ & 44.0747 & -113.9528 & 1.7 Mc IE & 105.2 & 0.04 & 12 & 276 & 43.3 & 0.27 & 3.8 & 8.5 \\
\hline $11 / 12 / 2013$ & $02: 02: 45.1$ & 44.4765 & -112.9962 & $0.9 \mathrm{Mc} \mathrm{IE}$ & 93.5 & 3.49 & 4 & 148 & 16.9 & 0.00 & 0.8 & 2.5 \\
\hline $11 / 12 / 2013$ & $06: 42: 29.3$ & 44.8612 & -112.7325 & $1.5 \mathrm{Mc} \mathrm{IE}$ & 134.8 & 7.89 & 6 & 288 & 66.5 & 0.13 & 12.9 & 2.1 \\
\hline $11 / 12 / 2013$ & $09: 35: 53.6$ & 43.4277 & -110.9030 & $0.9 \mathrm{Mc} \mathrm{IE}$ & 153.9 & 2.39 & 5 & 181 & 8.0 & 0.17 & 4.0 & 17.3 \\
\hline $11 / 12 / 2013$ & $10: 49: 38.2$ & 43.3807 & -110.9890 & 1.2 Mc IE & 148.1 & 11.26 & 9 & 166 & 11.3 & 0.03 & 1.5 & 1.6 \\
\hline $11 / 12 / 2013$ & $19: 47: 36.0$ & 43.2783 & -111.4762 & 1.1 Mc IE & 113.5 & 5.11 & 6 & 213 & 26.4 & 0.04 & 1.5 & 12.0 \\
\hline $11 / 12 / 2013$ & $21: 37: 15.7$ & 42.7717 & -111.5685 & $0.9 \mathrm{Mc} \mathrm{IE}$ & 138.8 & 4.36 & 4 & 294 & 35.2 & 0.05 & 7.8 & 11.7 \\
\hline $11 / 13 / 2013$ & $14: 10: 37.6$ & 44.9587 & -113.0820 & 1.1 Mc IE & 147.5 & 7.42 & 4 & 200 & 23.5 & 0.03 & 1.4 & 12.6 \\
\hline $11 / 13 / 2013$ & $14: 45: 45.5$ & 43.3205 & -111.1647 & $0.9 \mathrm{Mc} \mathrm{IE}$ & 135.9 & 12.59 & 9 & 165 & 25.6 & 0.12 & 0.8 & 2.6 \\
\hline $11 / 13 / 2013$ & $22: 25: 44.4$ & 42.7525 & -111.6028 & $0.9 \mathrm{Mc} \mathrm{IE}$ & 138.4 & 5.00 & 4 & 302 & 25.4 & 0.23 & 13.6 & 13.4 \\
\hline $11 / 14 / 2013$ & $04: 26: 56.0$ & 44.6723 & -111.8882 & $2.2 \mathrm{Mc} \mathrm{MB}$ & 134.4 & 5.36 & 21 & 104 & 18.8 & 0.04 & 0.4 & 0.9 \\
\hline $11 / 14 / 2013$ & $22: 13: 56.5$ & 42.7550 & -111.5737 & 1.2 Mc IE & 139.9 & 4.24 & 4 & 296 & 37.1 & 0.04 & 8.0 & 11.7 \\
\hline $11 / 16 / 2013$ & $17: 28: 46.9$ & 42.9275 & -111.0898 & 1.2 Mc IE & 159.1 & 4.98 & 4 & 162 & 18.0 & 0.07 & 1.0 & 11.0 \\
\hline $11 / 18 / 2013$ & $03: 21: 38.9$ & 42.7017 & -111.7708 & $1.8 \mathrm{Mc} \mathrm{IE}$ & 133.8 & 6.60 & 9 & 210 & 51.0 & 0.09 & 1.0 & 2.5 \\
\hline $11 / 18 / 2013$ & $12: 10: 50.7$ & 43.7183 & -111.0662 & $0.9 \mathrm{Mc} \mathrm{IE}$ & 138.6 & 7.35 & 6 & 190 & 9.4 & 0.06 & 1.5 & 1.9 \\
\hline $11 / 18 / 2013$ & $20: 26: 59.9$ & 42.9375 & -111.1468 & $1.9 \mathrm{Mc} \mathrm{IE}$ & 154.6 & 2.25 & 8 & 191 & 19.5 & 0.25 & 4.8 & 12.7 \\
\hline 11/18/2013 & 22:05:03.2 & 44.6862 & -112.9835 & 1.1 Mc IE & 116.4 & 6.62 & 3 & 175 & 19.0 & 0.21 & 9.4 & 18.0 \\
\hline
\end{tabular}


Table C-2. Continued.

\begin{tabular}{|c|c|c|c|c|c|c|c|c|c|c|c|c|}
\hline ORIGIN & TIME & LAT N & LONG W & MAG-TYP & DIST & $z$ & NO & GAP & DMIN & RMS & $\mathrm{ERH}$ & ERZ \\
\hline $11 / 18 / 2013$ & $22: 32: 26.1$ & 42.8388 & -111.5680 & $0.8 \mathrm{Mc} \mathrm{IE}$ & 133.7 & 2.48 & 6 & 146 & 16.3 & 0.08 & 2.6 & 13.3 \\
\hline $11 / 19 / 2013$ & 07:48:49.0 & 44.6010 & -114.2223 & 2.2 Mc MB & 156.4 & 0.16 & 18 & 144 & 72.6 & 0.16 & 1.2 & 5.0 \\
\hline $11 / 19 / 2013$ & $08: 49: 15.5$ & 43.7252 & -111.0905 & 1.1 Mc IE & 136.7 & 2.09 & 8 & 196 & 10.9 & 0.13 & 1.4 & 16.4 \\
\hline 11/19/2013 & $20: 14: 57.4$ & 44.3758 & -112.5730 & 1.1 Mc IE & 82.5 & 6.70 & 4 & 123 & 20.8 & 0.21 & 1.2 & 21.5 \\
\hline $11 / 20 / 2013$ & $04: 39: 45.9$ & 44.7570 & -111.5032 & 1.4 Mc IE & 160.1 & 0.37 & 5 & 257 & 13.2 & 0.14 & 6.4 & 10.1 \\
\hline $11 / 20 / 2013$ & $04: 45: 50.2$ & 42.7052 & -111.5303 & 1.1 Mc IE & 146.3 & 5.02 & 10 & 207 & 35.8 & 0.05 & 0.8 & 10.6 \\
\hline $11 / 20 / 2013$ & $05: 27: 11.5$ & 42.6973 & -111.5282 & 1.1 Mc IE & 147.1 & 5.05 & 6 & 300 & 35.8 & 0.04 & 1.6 & 10.9 \\
\hline $11 / 20 / 2013$ & 11:38:05.2 & 43.5733 & -111.6028 & $0.8 \mathrm{Mc} \mathrm{IE}$ & 95.6 & 5.00 & 5 & 287 & 47.1 & 0.15 & 2.1 & 17.6 \\
\hline $11 / 20 / 2013$ & $17: 22: 57.8$ & 43.2813 & -111.0377 & 1.1 Mc IE & 147.0 & 14.13 & 6 & 170 & 24.3 & 0.07 & 1.6 & 1.2 \\
\hline $11 / 20 / 2013$ & 21:31:53.9 & 42.7967 & -111.5083 & 1.1 Mc IE & 140.4 & 2.49 & 6 & 170 & 17.2 & 0.04 & 1.1 & 12.3 \\
\hline $11 / 21 / 2013$ & $20: 20: 50.8$ & 42.7143 & -111.5267 & $0.7 \mathrm{Mc} \mathrm{IE}$ & 145.8 & 5.02 & 4 & 298 & 26.3 & 0.09 & 2.9 & 13.2 \\
\hline $11 / 22 / 2013$ & $09: 11: 22.0$ & 42.9203 & -111.1068 & $0.6 \mathrm{Mc} \mathrm{IE}$ & 158.4 & 7.11 & 5 & 156 & 17.2 & 0.04 & 0.9 & 6.6 \\
\hline $11 / 22 / 2013$ & 11:08:07.9 & 44.5325 & -112.8273 & 1.1 Mc IE & 98.2 & 0.04 & 6 & 141 & 24.3 & 0.27 & 1.6 & 12.3 \\
\hline $11 / 22 / 2013$ & $13: 23: 39.0$ & 42.7143 & -111.5272 & 1.6 Mc IE & 145.8 & 1.37 & 18 & 93 & 26.3 & 0.07 & 0.4 & 1.6 \\
\hline $11 / 22 / 2013$ & $19: 50: 42.5$ & 44.6773 & -111.8813 & $0.9 \mathrm{Mc} \mathrm{IE}$ & 135.1 & 0.04 & 4 & 148 & 18.1 & 0.28 & 2.2 & 4.3 \\
\hline $11 / 22 / 2013$ & $22: 09: 19.1$ & 42.7972 & -111.5060 & 1.1 Mc IE & 140.6 & 3.64 & 5 & 286 & 17.1 & 0.04 & 5.8 & 9.2 \\
\hline $11 / 24 / 2013$ & $02: 32: 05.3$ & 44.7695 & -112.7808 & $0.9 \mathrm{Mc} \mathrm{IE}$ & 124.5 & 2.59 & 6 & 170 & 8.4 & 0.01 & 2.8 & 2.9 \\
\hline $11 / 24 / 2013$ & $09: 55: 57.6$ & 43.3932 & -111.0992 & 1.0 Mc IE & 139.0 & 9.60 & 5 & 273 & 16.1 & 0.00 & 6.6 & 5.2 \\
\hline $11 / 25 / 2013$ & $02: 57: 34.9$ & 44.5685 & -112.3675 & 1.3 Mc IE & 107.5 & 2.80 & 4 & 196 & 3.5 & 0.00 & 2.3 & 0.9 \\
\hline $11 / 25 / 2013$ & 19:10:08.4 & 43.2157 & -111.6605 & $0.7 \mathrm{Mc}$ IE & 102.9 & 5.15 & 4 & 270 & 29.7 & 0.13 & 5.5 & 13.4 \\
\hline $11 / 27 / 2013$ & $00: 44: 39.4$ & 43.5245 & -110.8495 & $0.6 \mathrm{Mc}$ IE & 156.7 & 5.30 & 5 & 229 & 9.0 & 0.13 & 7.1 & 15.0 \\
\hline 11/27/2013 & 04:15:01.3 & 43.0208 & -111.3862 & $0.2 \mathrm{Mc} \mathrm{IE}$ & 133.1 & 14.73 & 6 & 239 & 3.8 & 0.07 & 0.9 & 0.7 \\
\hline $11 / 27 / 2013$ & $21: 53: 54.3$ & 44.6210 & -112.6082 & 1.4 Mc IE & 108.9 & 6.38 & 6 & 139 & 17.3 & 0.07 & 0.8 & 12.0 \\
\hline $11 / 28 / 2013$ & 01:55:58.0 & 43.7245 & -111.1042 & $0.1 \mathrm{Mc} \mathrm{IE}$ & 135.5 & 3.59 & 6 & 240 & 11.4 & 0.05 & 3.0 & 9.4 \\
\hline $11 / 28 / 2013$ & $12: 01: 16.5$ & 43.7252 & -111.1052 & $0.5 \mathrm{Mc} \mathrm{IE}$ & 135.5 & 2.71 & 5 & 240 & 11.6 & 0.02 & 1.8 & 11.6 \\
\hline $11 / 29 / 2013$ & $00: 07: 14.3$ & 43.7228 & -111.0795 & 1.2 Mc IE & 137.5 & 4.73 & 7 & 193 & 10.3 & 0.10 & 1.3 & 3.2 \\
\hline $11 / 29 / 2013$ & $20: 46: 20.0$ & 43.7222 & -111.0832 & 1.1 Mc IE & 137.2 & 0.09 & 8 & 195 & 10.4 & 0.09 & 1.0 & 1.5 \\
\hline $11 / 30 / 2013$ & $14: 32: 33.1$ & 44.5155 & -113.6378 & 1.6 Mc IE & 118.1 & 7.58 & 6 & 253 & 29.3 & 0.04 & 3.7 & 12.0 \\
\hline $11 / 30 / 2013$ & $20: 10: 33.9$ & 43.7225 & -111.0795 & $0.8 \mathrm{Mc} \mathrm{IE}$ & 137.5 & 4.44 & 7 & 194 & 10.3 & 0.10 & 1.2 & 3.4 \\
\hline $12 / 1 / 2013$ & $07: 18: 34.5$ & 43.7228 & -111.0983 & $0.6 \mathrm{Mc} \mathrm{IE}$ & 136.0 & 2.26 & 8 & 198 & 11.0 & 0.08 & 1.5 & 12.2 \\
\hline $12 / 1 / 2013$ & $20: 21: 14.5$ & 44.3650 & -113.9993 & 1.0 Mc IE & 125.8 & 5.06 & 4 & 283 & 47.8 & 0.16 & 5.6 & 12.2 \\
\hline $12 / 1 / 2013$ & $21: 47: 45.8$ & 43.7168 & -111.0865 & $0.5 \mathrm{Mc} \mathrm{IE}$ & 136.9 & 6.33 & 9 & 196 & 10.0 & 0.12 & 1.1 & 2.3 \\
\hline $12 / 2 / 2013$ & $02: 46: 32.3$ & 43.7198 & -111.0740 & $0.5 \mathrm{Mc} \mathrm{IE}$ & 137.9 & 5.70 & 9 & 193 & 9.8 & 0.09 & 1.2 & 1.9 \\
\hline $12 / 2 / 2013$ & $05: 57: 55.1$ & 43.7138 & -111.0680 & 1.7 Mc IE & 138.4 & 6.42 & 17 & 120 & 9.0 & 0.16 & 0.7 & 1.9 \\
\hline $12 / 3 / 2013$ & $10: 48: 39.0$ & 43.7250 & -111.0700 & $0.5 \mathrm{Mc}$ IE & 138.3 & 0.06 & 7 & 191 & 10.3 & 0.07 & 1.0 & 1.4 \\
\hline $12 / 3 / 2013$ & $11: 21: 42.2$ & 43.7247 & -111.1102 & $0.5 \mathrm{Mc} \mathrm{IE}$ & 135.1 & 2.87 & 6 & 242 & 11.7 & 0.04 & 1.9 & 10.2 \\
\hline $12 / 3 / 2013$ & $15: 17: 16.1$ & 44.7958 & -113.0055 & 1.2 Mc IE & 128.7 & 5.22 & 6 & 223 & 12.9 & 0.09 & 6.1 & 13.3 \\
\hline $12 / 3 / 2013$ & $16: 41: 36.7$ & 44.7505 & -112.9832 & $0.8 \mathrm{Mc} \mathrm{IE}$ & 123.5 & 0.02 & 6 & 196 & 13.7 & 0.26 & 5.3 & 1.9 \\
\hline $12 / 4 / 2013$ & 02:23:05.2 & 43.7248 & -111.1193 & $0.8 \mathrm{Mc} \mathrm{IE}$ & 134.3 & 2.73 & 6 & 245 & 12.2 & 0.02 & 2.0 & 10.9 \\
\hline $12 / 4 / 2013$ & $02: 29: 34.9$ & 44.5487 & -112.9622 & 1.8 Mc IE & 101.0 & 4.98 & 9 & 142 & 24.4 & 0.05 & 0.6 & 0.9 \\
\hline $12 / 4 / 2013$ & $10: 38: 57.7$ & 43.4057 & -110.8597 & 1.1 Mc IE & 157.8 & 8.03 & 9 & 163 & 4.9 & 0.20 & 1.4 & 1.2 \\
\hline $12 / 4 / 2013$ & $16: 05: 21.7$ & 43.7218 & -111.0982 & $0.5 \mathrm{Mc} \mathrm{IE}$ & 136.0 & 5.34 & 6 & 238 & 10.9 & 0.01 & 3.4 & 3.7 \\
\hline $12 / 4 / 2013$ & $16: 05: 45.6$ & 43.7257 & -111.1037 & $0.9 \mathrm{Mc} \mathrm{IE}$ & 135.6 & 2.69 & 6 & 240 & 11.5 & 0.09 & 2.4 & 11.5 \\
\hline $12 / 4 / 2013$ & $16: 47: 30.5$ & 43.7245 & -111.1070 & 1.0 Mc IE & 135.3 & 2.97 & 9 & 241 & 11.6 & 0.06 & 2.3 & 10.3 \\
\hline $12 / 4 / 2013$ & $17: 16: 40.5$ & 43.7227 & -111.0802 & 1.3 Mc IE & 137.5 & 0.03 & 9 & 195 & 10.3 & 0.10 & 1.2 & 0.9 \\
\hline $12 / 4 / 2013$ & $17: 58: 40.8$ & 43.7272 & -111.1062 & $0.8 \mathrm{Mc} \mathrm{IE}$ & 135.4 & 2.26 & 5 & 241 & 11.8 & 0.10 & 3.0 & 13.5 \\
\hline $12 / 4 / 2013$ & 21:05:20.0 & 43.7232 & -111.1073 & $0.6 \mathrm{Mc} \mathrm{IE}$ & 135.3 & 4.71 & 6 & 201 & 11.5 & 0.02 & 1.3 & 4.4 \\
\hline $12 / 4 / 2013$ & $22: 19: 22.1$ & 42.7962 & -111.5265 & 1.2 Mc IE & 139.4 & 2.61 & 8 & 183 & 17.9 & 0.08 & 0.9 & 12.5 \\
\hline $12 / 5 / 2013$ & 09:09:14.1 & 43.7245 & -111.0572 & $1.0 \mathrm{Mc} \mathrm{IE}$ & 139.3 & 0.06 & 9 & 185 & 9.9 & 0.13 & 1.7 & 0.8 \\
\hline $12 / 5 / 2013$ & $16: 32: 45.2$ & 43.7277 & -111.1142 & 1.0 Mc IE & 134.8 & 4.88 & 5 & 243 & 23.5 & 0.11 & 3.4 & 13.4 \\
\hline $12 / 5 / 2013$ & $17: 39: 42.5$ & 42.9805 & -111.6287 & $0.9 \mathrm{Mc} \mathrm{IE}$ & 119.6 & 5.33 & 4 & 256 & 49.4 & 0.20 & 10.5 & 11.3 \\
\hline
\end{tabular}


Table C-2. Continued.

\begin{tabular}{|c|c|c|c|c|c|c|c|c|c|c|c|c|}
\hline ORIGIN & TIME & LAT N & LONG W & MAG-TYP & DIST & $z$ & NO & GAP & DMIN & RMS & $\mathrm{ERH}$ & ERZ \\
\hline $12 / 6 / 2013$ & $00: 02: 29.5$ & 42.9080 & -111.3740 & 1.8 Mc IE & 141.0 & 6.51 & 9 & 174 & 16.2 & 0.06 & 0.8 & 2.5 \\
\hline $12 / 6 / 2013$ & $01: 36: 55.5$ & 43.7213 & -111.0662 & 1.0 Mc IE & 138.6 & 0.34 & 8 & 189 & 9.8 & 0.08 & 1.4 & 0.8 \\
\hline $12 / 6 / 2013$ & $01: 48: 25.9$ & 43.7287 & -111.0770 & 1.1 Mc IE & 137.8 & 2.23 & 7 & 193 & 10.8 & 0.13 & 2.5 & 14.1 \\
\hline $12 / 6 / 2013$ & $06: 36: 44.9$ & 43.7270 & -111.0972 & $0.9 \mathrm{Mc}$ IE & 136.1 & 0.40 & 7 & 238 & 11.4 & 0.10 & 9.0 & 6.5 \\
\hline $12 / 6 / 2013$ & $07: 15: 17.9$ & 43.9957 & -114.4155 & 1.7 Mc IE & 136.8 & 3.75 & 7 & 306 & 77.7 & 0.03 & 4.3 & 10.2 \\
\hline $12 / 6 / 2013$ & $18: 38: 38.8$ & 44.9265 & -112.7900 & 1.0 Mc IE & 142.0 & 3.49 & 5 & 161 & 11.9 & 0.07 & 1.1 & 2.2 \\
\hline $12 / 7 / 2013$ & 17:08:19.1 & 44.1742 & -113.8483 & 1.7 Mc IE & 103.5 & 7.05 & 7 & 279 & 38.5 & 0.14 & 1.9 & 17.0 \\
\hline $12 / 7 / 2013$ & $23: 19: 40.1$ & 44.1495 & -113.9012 & 1.0 Mc IE & 105.6 & 4.89 & 4 & 301 & 43.5 & 0.01 & 4.7 & 9.2 \\
\hline $12 / 8 / 2013$ & $22: 17: 24.0$ & 43.2908 & -110.8902 & $0.9 \mathrm{Mc}$ IE & 158.2 & 4.06 & 5 & 207 & 8.5 & 0.16 & 5.9 & 13.4 \\
\hline $12 / 8 / 2013$ & 23:01:10.3 & 43.1652 & -110.9555 & $0.6 \mathrm{Mc}$ IE & 157.5 & 5.20 & 5 & 334 & 23.5 & 0.06 & 3.0 & 13.1 \\
\hline $12 / 8 / 2013$ & $23: 47: 36.3$ & 42.8538 & -111.2593 & $0.7 \mathrm{Mc} \mathrm{IE}$ & 152.1 & 12.01 & 4 & 179 & 16.2 & 0.00 & 2.3 & 3.4 \\
\hline $12 / 9 / 2013$ & $06: 02: 10.6$ & 44.2413 & -113.9797 & $1.4 \mathrm{Mc} \mathrm{IE}$ & 116.4 & 7.17 & 12 & 253 & 46.5 & 0.15 & 0.9 & 7.2 \\
\hline $12 / 9 / 2013$ & $16: 03: 06.3$ & 43.3922 & -110.9720 & $2.4 \mathrm{Mc} \mathrm{IE}$ & 149.1 & 4.80 & 5 & 154 & 10.3 & 0.06 & 3.2 & 12.8 \\
\hline $12 / 10 / 2013$ & $02: 12: 08.2$ & 43.4063 & -111.2278 & $0.7 \mathrm{Mc} \mathrm{IE}$ & 128.6 & 10.70 & 11 & 118 & 30.4 & 0.19 & 0.6 & 2.1 \\
\hline $12 / 11 / 2013$ & $11: 13: 04.9$ & 44.5552 & -114.1475 & $1.9 \mathrm{Mc} \mathrm{IE}$ & 148.5 & 0.02 & 14 & 265 & 65.0 & 0.21 & 2.8 & 3.2 \\
\hline $12 / 11 / 2013$ & $13: 28: 16.5$ & 43.5875 & -113.7190 & $0.5 \mathrm{Mc}$ IE & 75.8 & 12.40 & 8 & 285 & 19.8 & 0.14 & 1.1 & 1.4 \\
\hline $12 / 12 / 2013$ & 03:33:48.6 & 43.7077 & -113.7323 & 1.1 Mc IE & 76.8 & 1.22 & 13 & 224 & 22.7 & 0.12 & 0.9 & 1.7 \\
\hline $12 / 12 / 2013$ & $22: 16: 47.2$ & 42.7580 & -111.5470 & 1.4 Mc IE & 141.2 & 3.84 & 4 & 353 & 35.9 & 0.02 & 7.3 & 11.7 \\
\hline $12 / 14 / 2013$ & $04: 33: 48.3$ & 44.5577 & -112.0835 & 1.3 Mc IE & 115.5 & 5.76 & 5 & 290 & 122.2 & 0.08 & 8.6 & 11.5 \\
\hline $12 / 14 / 2013$ & $06: 21: 04.3$ & 43.4373 & -110.9435 & 1.1 Mc IE & 150.5 & 23.42 & 4 & 349 & 5.9 & 0.19 & 20.2 & 1.9 \\
\hline $12 / 14 / 2013$ & $14: 08: 32.0$ & 44.5577 & -113.0363 & $2.0 \mathrm{Mc} \mathrm{IE}$ & 103.0 & 0.16 & 7 & 158 & 26.5 & 0.10 & 0.8 & 8.8 \\
\hline $12 / 14 / 2013$ & $14: 30: 46.7$ & 44.5600 & -113.0420 & 1.8 Mc IE & 103.3 & 0.02 & 6 & 160 & 26.9 & 0.17 & 1.1 & 4.4 \\
\hline $12 / 14 / 2013$ & $18: 57: 00.2$ & 43.4268 & -110.9238 & $0.6 \mathrm{Mc} \mathrm{IE}$ & 152.2 & 9.52 & 4 & 358 & 7.4 & 0.14 & 16.8 & 1.3 \\
\hline $12 / 15 / 2013$ & $10: 25: 47.5$ & 44.6143 & -113.0355 & 1.4 Mc IE & 109.2 & 3.64 & 16 & 169 & 27.9 & 0.24 & 0.5 & 1.1 \\
\hline $12 / 16 / 2013$ & $12: 47: 46.2$ & 43.0622 & -111.6438 & $0.4 \mathrm{Mc} \mathrm{IE}$ & 113.1 & 2.22 & 7 & 171 & 22.3 & 0.13 & 0.8 & 16.4 \\
\hline $12 / 16 / 2013$ & $14: 18: 07.2$ & 44.2573 & -113.9492 & 1.4 Mc IE & 115.4 & 6.93 & 17 & 281 & 43.8 & 0.17 & 0.7 & 7.6 \\
\hline $12 / 16 / 2013$ & $16: 45: 52.2$ & 43.7177 & -111.0827 & $0.4 \mathrm{Mc}$ IE & 137.2 & 2.25 & 8 & 198 & 9.9 & 0.08 & 0.8 & 11.8 \\
\hline $12 / 16 / 2013$ & $22: 12: 17.7$ & 42.7535 & -111.6025 & $0.5 \mathrm{Mc} \mathrm{IE}$ & 138.4 & 3.46 & 8 & 297 & 25.3 & 0.13 & 1.2 & 13.7 \\
\hline $12 / 17 / 2013$ & $13: 34: 23.0$ & 43.7168 & -111.0092 & $0.2 \mathrm{Mc} \mathrm{IE}$ & 143.2 & 3.05 & 8 & 156 & 8.9 & 0.08 & 2.0 & 7.6 \\
\hline $12 / 17 / 2013$ & $22: 26: 51.7$ & 42.7913 & -111.5403 & 1.1 Mc IE & 139.0 & 9.98 & 11 & 188 & 19.0 & 0.05 & 0.5 & 1.5 \\
\hline $12 / 18 / 2013$ & $09: 07: 32.3$ & 43.2460 & -110.9778 & $0.5 \mathrm{Mc} \mathrm{IE}$ & 152.8 & 16.32 & 11 & 153 & 16.5 & 0.11 & 0.8 & 0.8 \\
\hline $12 / 19 / 2013$ & $01: 36: 42.4$ & 43.7132 & -111.0995 & $0.3 \mathrm{Mc} \mathrm{IE}$ & 135.9 & 5.85 & 8 & 199 & 10.2 & 0.07 & 1.4 & 1.4 \\
\hline $12 / 19 / 2013$ & 03:29:38.1 & 43.7180 & -111.0753 & $0.8 \mathrm{Mc}$ IE & 137.8 & 5.97 & 10 & 193 & 9.7 & 0.11 & 1.1 & 1.9 \\
\hline $12 / 19 / 2013$ & 09:39:58.6 & 43.7168 & -111.1043 & $0.6 \mathrm{Mc}$ IE & 135.5 & 4.20 & 10 & 201 & 10.7 & 0.11 & 1.0 & 3.1 \\
\hline $12 / 20 / 2013$ & 05:01:21.5 & 43.0593 & -111.6283 & $0.6 \mathrm{Mc}$ IE & 114.3 & 12.87 & 8 & 268 & 21.0 & 0.10 & 1.1 & 1.0 \\
\hline $12 / 20 / 2013$ & 09:08:02.4 & 43.7143 & -111.0980 & $0.6 \mathrm{Mc} \mathrm{IE}$ & 136.0 & 2.93 & 12 & 199 & 10.2 & 0.13 & 1.1 & 6.4 \\
\hline $12 / 20 / 2013$ & $10: 01: 43.6$ & 43.7142 & -111.0837 & $0.5 \mathrm{Mc} \mathrm{IE}$ & 137.1 & 5.68 & 9 & 196 & 9.6 & 0.07 & 1.0 & 1.7 \\
\hline $12 / 20 / 2013$ & $11: 30: 08.9$ & 43.7110 & -111.0708 & $0.5 \mathrm{Mc}$ IE & 138.2 & 6.29 & 9 & 193 & 8.8 & 0.10 & 1.1 & 1.7 \\
\hline $12 / 20 / 2013$ & $12: 16: 45.8$ & 43.7238 & -111.0727 & $0.8 \mathrm{Mc} \mathrm{IE}$ & 138.1 & 2.06 & 13 & 152 & 10.2 & 0.11 & 0.8 & 15.8 \\
\hline $12 / 20 / 2013$ & $12: 39: 58.1$ & 43.7290 & -111.0685 & $0.8 \mathrm{Mc}$ IE & 138.4 & 5.61 & 12 & 189 & 10.6 & 0.11 & 0.9 & 2.0 \\
\hline $12 / 20 / 2013$ & $13: 39: 43.7$ & 43.7195 & -111.0970 & $0.3 \mathrm{Mc}$ IE & 136.1 & 2.18 & 8 & 243 & 10.7 & 0.06 & 1.5 & 12.1 \\
\hline $12 / 20 / 2013$ & $20: 25: 19.5$ & 44.4808 & -113.9420 & 1.1 Mc IE & 131.0 & 7.70 & 8 & 278 & 46.8 & 0.07 & 0.9 & 1.4 \\
\hline $12 / 21 / 2013$ & $06: 22: 56.9$ & 44.1435 & -114.4687 & 1.4 Mc IE & 146.1 & 6.80 & 11 & 125 & 84.9 & 0.21 & 1.1 & 2.2 \\
\hline $12 / 22 / 2013$ & 01:07:20.1 & 42.7860 & -111.4048 & $0.8 \mathrm{Mc}$ IE & 147.5 & 6.87 & 10 & 261 & 16.9 & 0.13 & 1.0 & 2.5 \\
\hline $12 / 22 / 2013$ & 01:58:26.0 & 44.1698 & -113.2462 & $0.8 \mathrm{Mc} \mathrm{IE}$ & 68.8 & 0.19 & 4 & 189 & 20.2 & 0.02 & 0.8 & 2.1 \\
\hline $12 / 22 / 2013$ & $06: 04: 27.8$ & 43.7167 & -111.0902 & 1.3 Mc IE & 136.6 & 4.61 & 11 & 197 & 10.1 & 0.09 & 1.0 & 2.5 \\
\hline $12 / 23 / 2013$ & 05:21:01.6 & 44.6495 & -112.6147 & $1.3 \mathrm{Mc}$ IE & 112.0 & 15.78 & 15 & 81 & 18.6 & 0.09 & 0.3 & 0.5 \\
\hline $12 / 23 / 2013$ & 09:09:48.0 & 43.0773 & -110.9630 & $0.8 \mathrm{Mc} \mathrm{IE}$ & 160.6 & 12.64 & 8 & 183 & 32.9 & 0.10 & 0.9 & 3.4 \\
\hline $12 / 23 / 2013$ & $13: 09: 52.5$ & 44.1017 & -113.8872 & 1.7 Mc IE & 102.0 & 7.16 & 19 & 244 & 39.8 & 0.16 & 0.6 & 3.1 \\
\hline $12 / 24 / 2013$ & 02:07:45.9 & 42.6375 & -111.4433 & 1.0 Mc IE & 156.7 & 9.89 & 9 & 157 & 31.5 & 0.11 & 0.6 & 1.0 \\
\hline $12 / 24 / 2013$ & 08:40:06.9 & 44.1945 & -113.1498 & $0.8 \mathrm{Mc}$ IE & 67.3 & 1.72 & 7 & 163 & 22.3 & 0.19 & 0.8 & 20.0 \\
\hline
\end{tabular}


Table C-2. Continued.

\begin{tabular}{|c|c|c|c|c|c|c|c|c|c|c|c|c|}
\hline ORIGIN & TIME & LAT N & LONG W & MAG-TYP & DIST & $z$ & NO & GAP & DMIN & RMS & $\mathrm{ERH}$ & ERZ \\
\hline $12 / 24 / 2013$ & $21: 08: 27.8$ & 42.8422 & -111.2920 & $0.6 \mathrm{Mc}$ IE & 150.7 & 13.41 & 4 & 198 & 15.0 & 0.05 & 1.3 & 1.6 \\
\hline $12 / 25 / 2013$ & $06: 16: 46.8$ & 44.4373 & -112.8243 & 1.1 Mc IE & 87.7 & 6.08 & 12 & 106 & 15.2 & 0.11 & 0.5 & 0.7 \\
\hline $12 / 25 / 2013$ & $11: 02: 57.5$ & 43.7230 & -111.1168 & 1.0 Mc IE & 134.5 & 2.00 & 11 & 203 & 11.9 & 0.17 & 1.2 & 19.1 \\
\hline $12 / 25 / 2013$ & $21: 17: 07.6$ & 43.7203 & -111.0730 & $2.0 \mathrm{Mc}$ IE & 138.0 & 2.26 & 18 & 119 & 9.9 & 0.13 & 0.8 & 12.1 \\
\hline $12 / 25 / 2013$ & $22: 02: 24.9$ & 43.7122 & -111.0907 & $0.9 \mathrm{Mc} \mathrm{IE}$ & 136.6 & 5.29 & 9 & 198 & 9.7 & 0.12 & 1.1 & 2.2 \\
\hline $12 / 26 / 2013$ & 05:38:18.0 & 44.5762 & -112.6858 & $0.9 \mathrm{Mc} \mathrm{IE}$ & 103.3 & 4.32 & 10 & 92 & 23.2 & 0.18 & 0.7 & 2.0 \\
\hline $12 / 26 / 2013$ & $07: 53: 38.9$ & 42.8775 & -111.2523 & $0.8 \mathrm{Mc} \mathrm{IE}$ & 151.1 & 10.47 & 9 & 161 & 15.4 & 0.06 & 0.6 & 1.8 \\
\hline $12 / 26 / 2013$ & 07:58:03.5 & 42.8777 & -111.2560 & 1.0 Mc IE & 150.8 & 10.62 & 10 & 163 & 15.1 & 0.08 & 0.6 & 1.9 \\
\hline $12 / 26 / 2013$ & $12: 33: 26.8$ & 42.8658 & -111.2628 & $0.4 \mathrm{Mc} \mathrm{IE}$ & 151.1 & 13.34 & 6 & 173 & 15.2 & 0.11 & 0.6 & 1.7 \\
\hline $12 / 26 / 2013$ & $13: 41: 43.6$ & 43.7153 & -111.0823 & $0.6 \mathrm{Mc}$ IE & 137.3 & 4.65 & 9 & 196 & 9.7 & 0.17 & 1.4 & 2.8 \\
\hline $12 / 26 / 2013$ & $13: 54: 57.5$ & 43.7172 & -111.0918 & $0.7 \mathrm{Mc} \mathrm{IE}$ & 136.5 & 0.02 & 10 & 198 & 10.2 & 0.10 & 1.0 & 0.8 \\
\hline $12 / 26 / 2013$ & $23: 43: 19.4$ & 43.7137 & -111.1102 & 1.9 ML IE & 135.0 & 4.77 & 17 & 142 & 10.8 & 0.13 & 0.7 & 2.5 \\
\hline $12 / 26 / 2013$ & $23: 45: 54.6$ & 43.7135 & -111.0968 & $0.6 \mathrm{Mc} \mathrm{IE}$ & 136.1 & 6.97 & 7 & 199 & 10.1 & 0.09 & 1.0 & 2.0 \\
\hline $12 / 26 / 2013$ & $23: 52: 21.3$ & 43.0308 & -111.4002 & $2.5 \mathrm{ML} \mathrm{IE}$ & 131.6 & 8.96 & 23 & 90 & 3.5 & 0.15 & 0.4 & 0.6 \\
\hline $12 / 27 / 2013$ & $00: 12: 04.1$ & 43.7150 & -111.0868 & $2.2 \mathrm{Mc} \mathrm{IE}$ & 136.9 & 5.08 & 16 & 154 & 9.8 & 0.08 & 0.7 & 1.7 \\
\hline $12 / 27 / 2013$ & 01:13:08.1 & 43.7245 & -111.1783 & $0.9 \mathrm{Mc} \mathrm{IE}$ & 129.6 & 2.45 & 7 & 257 & 15.5 & 0.09 & 2.9 & 13.4 \\
\hline $12 / 27 / 2013$ & $05: 54: 52.5$ & 43.7127 & -111.0105 & $0.6 \mathrm{Mc} \mathrm{IE}$ & 143.0 & 3.76 & 7 & 156 & 8.4 & 0.18 & 1.3 & 5.3 \\
\hline $12 / 27 / 2013$ & $06: 22: 58.5$ & 43.7215 & -111.0620 & $0.8 \mathrm{Mc} \mathrm{IE}$ & 138.9 & 0.06 & 10 & 188 & 9.7 & 0.14 & 1.2 & 0.9 \\
\hline $12 / 27 / 2013$ & $07: 10: 29.5$ & 43.7202 & -111.0918 & $0.8 \mathrm{Mc} \mathrm{IE}$ & 136.5 & 0.20 & 10 & 198 & 10.5 & 0.09 & 1.0 & 0.8 \\
\hline $12 / 27 / 2013$ & 07:11:36.0 & 43.7250 & -111.0680 & $0.8 \mathrm{Mc}$ IE & 138.5 & 0.03 & 10 & 189 & 10.2 & 0.11 & 1.1 & 0.8 \\
\hline $12 / 27 / 2013$ & $07: 15: 36.3$ & 43.7225 & -111.0682 & 1.0 Mc IE & 138.4 & 0.29 & 10 & 191 & 9.9 & 0.12 & 1.1 & 0.9 \\
\hline $12 / 27 / 2013$ & 07:19:10.7 & 43.7248 & -111.0535 & 1.6 Mc IE & 139.6 & 1.14 & 13 & 122 & 9.9 & 0.12 & 0.7 & 1.1 \\
\hline $12 / 27 / 2013$ & $07: 30: 20.5$ & 43.7380 & -111.0847 & $0.9 \mathrm{Mc} \mathrm{IE}$ & 137.2 & 3.10 & 6 & 357 & 12.0 & 0.03 & 11.5 & 6.3 \\
\hline $12 / 27 / 2013$ & $07: 44: 41.4$ & 43.7310 & -111.1000 & $0.9 \mathrm{Mc} \mathrm{IE}$ & 135.9 & 2.02 & 6 & 355 & 11.9 & 0.07 & 6.5 & 13.6 \\
\hline $12 / 27 / 2013$ & $07: 55: 49.0$ & 43.7185 & -111.0953 & $0.8 \mathrm{Mc} \mathrm{IE}$ & 136.2 & 2.34 & 7 & 198 & 10.5 & 0.11 & 1.2 & 11.4 \\
\hline $12 / 27 / 2013$ & $08: 19: 31.4$ & 43.7223 & -111.1012 & $0.8 \mathrm{Mc} \mathrm{IE}$ & 135.8 & 0.06 & 6 & 199 & 11.1 & 0.23 & 7.9 & 1.3 \\
\hline $12 / 27 / 2013$ & 09:11:05.3 & 43.7438 & -111.0830 & $0.9 \mathrm{Mc} \mathrm{IE}$ & 137.4 & 1.96 & 5 & 357 & 12.6 & 0.05 & 11.7 & 10.7 \\
\hline $12 / 27 / 2013$ & 09:19:29.2 & 43.7458 & -111.0820 & $0.7 \mathrm{Mc} \mathrm{IE}$ & 137.5 & 2.32 & 5 & 357 & 12.8 & 0.08 & 12.7 & 11.5 \\
\hline $12 / 27 / 2013$ & $10: 23: 00.5$ & 43.7223 & -111.0735 & $0.8 \mathrm{Mc} \mathrm{IE}$ & 138.0 & 6.07 & 4 & 360 & 10.1 & 0.02 & 12.6 & 1.9 \\
\hline $12 / 27 / 2013$ & $14: 48: 31.1$ & 43.7173 & -111.1152 & 1.0 Mc IE & 134.6 & 2.21 & 7 & 247 & 11.3 & 0.09 & 1.6 & 13.1 \\
\hline $12 / 27 / 2013$ & $15: 24: 09.3$ & 43.7173 & -111.0998 & $0.8 \mathrm{Mc} \mathrm{IE}$ & 135.9 & 0.05 & 6 & 199 & 10.6 & 0.09 & 4.4 & 1.0 \\
\hline $12 / 27 / 2013$ & $18: 02: 25.1$ & 43.7182 & -111.0998 & 1.2 Mc IE & 135.9 & 2.09 & 6 & 199 & 10.7 & 0.11 & 2.1 & 15.7 \\
\hline $12 / 27 / 2013$ & $18: 11: 46.1$ & 43.7080 & -111.0582 & $0.9 \mathrm{Mc}$ IE & 139.2 & 6.81 & 4 & 189 & 8.2 & 0.08 & 12.8 & 1.8 \\
\hline $12 / 27 / 2013$ & $19: 07: 10.2$ & 43.7170 & -111.1040 & 1.1 Mc IE & 135.5 & 2.39 & 9 & 201 & 10.7 & 0.11 & 1.3 & 11.8 \\
\hline $12 / 27 / 2013$ & $20: 36: 16.4$ & 43.7192 & -111.1035 & 1.0 Mc IE & 135.6 & 2.47 & 7 & 200 & 10.9 & 0.12 & 2.1 & 12.1 \\
\hline $12 / 27 / 2013$ & $21: 23: 59.1$ & 43.7408 & -111.0852 & 1.0 Mc IE & 137.2 & 2.23 & 5 & 357 & 12.3 & 0.08 & 9.6 & 10.4 \\
\hline $12 / 27 / 2013$ & $23: 22: 58.7$ & 43.7175 & -111.1162 & $0.8 \mathrm{Mc} \mathrm{IE}$ & 134.5 & 2.72 & 5 & 247 & 11.4 & 0.09 & 1.8 & 12.7 \\
\hline $12 / 27 / 2013$ & $23: 28: 42.5$ & 43.7418 & -111.0963 & $0.7 \mathrm{Mc}$ IE & 136.3 & 2.24 & 4 & 360 & 12.8 & 0.20 & 20.8 & 18.9 \\
\hline $12 / 27 / 2013$ & $23: 28: 50.0$ & 43.7257 & -111.0720 & $0.8 \mathrm{Mc} \mathrm{IE}$ & 138.1 & 2.44 & 4 & 192 & 10.4 & 0.07 & 8.9 & 8.4 \\
\hline $12 / 27 / 2013$ & $23: 49: 27.7$ & 43.4473 & -111.2045 & 1.2 Mc IE & 129.5 & 4.47 & 5 & 286 & 21.1 & 0.07 & 1.9 & 13.6 \\
\hline $12 / 28 / 2013$ & $04: 57: 35.5$ & 43.7200 & -111.1102 & $0.8 \mathrm{Mc}$ IE & 135.0 & 2.27 & 6 & 246 & 11.3 & 0.07 & 1.4 & 12.8 \\
\hline $12 / 28 / 2013$ & $05: 36: 03.5$ & 44.2557 & -114.2412 & 2.1 Mc MB & 135.0 & 4.77 & 14 & 295 & 67.0 & 0.09 & 1.6 & 3.8 \\
\hline $12 / 28 / 2013$ & $07: 46: 14.4$ & 43.7165 & -111.0898 & $0.9 \mathrm{Mc} \mathrm{IE}$ & 136.7 & 4.52 & 9 & 197 & 10.1 & 0.11 & 1.1 & 2.9 \\
\hline $12 / 28 / 2013$ & 08:35:39.4 & 43.7157 & -111.0965 & $0.9 \mathrm{Mc} \mathrm{IE}$ & 136.1 & 3.86 & 10 & 199 & 10.3 & 0.09 & 1.1 & 3.7 \\
\hline $12 / 28 / 2013$ & $10: 40: 16.5$ & 43.7243 & -111.0838 & $0.6 \mathrm{Mc} \mathrm{IE}$ & 137.2 & 0.03 & 9 & 195 & 10.6 & 0.14 & 1.2 & 0.7 \\
\hline $12 / 28 / 2013$ & $12: 26: 07.7$ & 43.7107 & -111.0740 & $0.8 \mathrm{Mc} \mathrm{IE}$ & 137.9 & 6.24 & 10 & 194 & 8.9 & 0.12 & 1.0 & 1.6 \\
\hline $12 / 28 / 2013$ & $13: 40: 38.1$ & 43.7412 & -110.9498 & $0.9 \mathrm{Mc} \mathrm{IE}$ & 148.1 & 2.49 & 7 & 154 & 13.0 & 0.24 & 1.4 & 21.5 \\
\hline $12 / 28 / 2013$ & $14: 21: 44.0$ & 43.7152 & -111.0912 & $0.7 \mathrm{Mc} \mathrm{IE}$ & 136.5 & 5.52 & 10 & 198 & 10.0 & 0.08 & 1.0 & 2.0 \\
\hline $12 / 28 / 2013$ & $14: 55: 50.7$ & 43.7212 & -111.1055 & 1.7 Mc IE & 135.4 & 2.54 & 15 & 107 & 11.2 & 0.12 & 0.8 & 8.6 \\
\hline $12 / 28 / 2013$ & $15: 09: 27.8$ & 43.0440 & -111.4245 & $0.8 \mathrm{Mc}$ IE & 129.1 & 4.50 & 9 & 207 & 4.5 & 0.12 & 0.7 & 1.0 \\
\hline $12 / 28 / 2013$ & $19: 30: 37.1$ & 43.7062 & -111.1002 & 0.0 NoMag & 135.8 & 8.13 & 8 & 201 & 9.6 & 0.14 & 2.0 & 1.5 \\
\hline
\end{tabular}


Table C-2. Continued.

\begin{tabular}{|c|c|c|c|c|c|c|c|c|c|c|c|c|}
\hline ORIGIN & TIME & LAT N & LONG W & MAG-TYP & DIST & $z$ & NO & GAP & DMIN & RMS & $\mathrm{ERH}$ & ERZ \\
\hline $12 / 28 / 2013$ & $21: 59: 55.7$ & 43.7175 & -111.0963 & $0.9 \mathrm{Mc}$ IE & 136.1 & 4.11 & 9 & 199 & 10.4 & 0.10 & 1.0 & 3.3 \\
\hline $12 / 28 / 2013$ & $22: 28: 05.5$ & 43.7200 & -111.0893 & 2.2 Mc IE & 136.7 & 0.30 & 18 & 113 & 10.4 & 0.05 & 0.4 & 0.6 \\
\hline $12 / 28 / 2013$ & $22: 43: 45.7$ & 43.7182 & -111.0905 & 1.0 Mc IE & 136.6 & 1.91 & 9 & 198 & 10.3 & 0.08 & 0.8 & 1.4 \\
\hline $12 / 28 / 2013$ & 23:08:31.7 & 43.7195 & -111.0815 & $0.8 \mathrm{Mc}$ IE & 137.3 & 0.15 & 10 & 195 & 10.1 & 0.12 & 1.1 & 0.9 \\
\hline $12 / 29 / 2013$ & $00: 38: 05.8$ & 43.7215 & -111.0825 & $2.8 \mathrm{ML} \mathrm{MB}$ & 137.3 & 0.05 & 16 & 117 & 10.3 & 0.11 & 0.7 & 0.6 \\
\hline $12 / 29 / 2013$ & $01: 29: 42.9$ & 43.7113 & -111.0877 & $0.6 \mathrm{Mc}$ IE & 136.8 & 6.75 & 7 & 197 & 9.5 & 0.05 & 1.0 & 1.7 \\
\hline $12 / 29 / 2013$ & $02: 11: 40.4$ & 43.7185 & -111.0867 & $0.9 \mathrm{Mc} \mathrm{IE}$ & 136.9 & 4.60 & 11 & 196 & 10.1 & 0.09 & 1.0 & 2.6 \\
\hline $12 / 29 / 2013$ & $04: 46: 10.4$ & 43.7048 & -111.1300 & $0.7 \mathrm{Mc} \mathrm{IE}$ & 133.4 & 2.49 & 7 & 207 & 11.1 & 0.18 & 2.6 & 18.3 \\
\hline $12 / 29 / 2013$ & $05: 38: 51.2$ & 43.7193 & -111.0897 & $0.8 \mathrm{Mc} \mathrm{IE}$ & 136.7 & 2.16 & 10 & 196 & 10.4 & 0.10 & 1.0 & 13.5 \\
\hline $12 / 29 / 2013$ & 08:46:04.9 & 43.7145 & -111.0892 & $2.5 \mathrm{ML}$ US & 136.7 & 5.50 & 25 & 112 & 9.9 & 0.10 & 0.4 & 1.4 \\
\hline $12 / 29 / 2013$ & 08:58:56.4 & 43.7157 & -111.1020 & $0.8 \mathrm{Mc} \mathrm{IE}$ & 135.7 & 2.19 & 9 & 201 & 10.5 & 0.06 & 0.9 & 11.6 \\
\hline $12 / 29 / 2013$ & 09:07:12.0 & 43.7170 & -111.0808 & $0.8 \mathrm{Mc} \mathrm{IE}$ & 137.4 & 5.67 & 9 & 195 & 9.8 & 0.07 & 0.9 & 1.7 \\
\hline $12 / 29 / 2013$ & 10:08:02.9 & 43.7203 & -111.0722 & 2.1 Mc IE & 138.1 & 0.31 & 16 & 119 & 9.8 & 0.11 & 0.6 & 0.6 \\
\hline $12 / 29 / 2013$ & $10: 16: 28.4$ & 43.7170 & -111.0905 & $0.8 \mathrm{Mc} \mathrm{IE}$ & 136.6 & 2.25 & 11 & 137 & 10.2 & 0.11 & 1.1 & 11.9 \\
\hline $12 / 29 / 2013$ & $10: 39: 47.8$ & 43.7228 & -111.0833 & 1.6 Mc IE & 137.2 & 4.28 & 14 & 154 & 10.5 & 0.12 & 0.8 & 2.5 \\
\hline $12 / 29 / 2013$ & $10: 53: 44.5$ & 43.7587 & -110.8735 & $0.8 \mathrm{Mc} \mathrm{IE}$ & 154.3 & 10.20 & 9 & 156 & 18.2 & 0.06 & 0.6 & 2.3 \\
\hline $12 / 29 / 2013$ & $11: 30: 20.9$ & 43.7222 & -111.0865 & $0.8 \mathrm{Mc} \mathrm{IE}$ & 136.9 & 4.81 & 9 & 196 & 10.5 & 0.08 & 1.0 & 2.4 \\
\hline $12 / 29 / 2013$ & $12: 07: 12.9$ & 43.7205 & -111.0990 & $0.6 \mathrm{Mc} \mathrm{IE}$ & 135.9 & 2.84 & 9 & 199 & 10.8 & 0.06 & 1.0 & 6.6 \\
\hline $12 / 29 / 2013$ & $12: 33: 40.6$ & 43.7168 & -111.0973 & $0.8 \mathrm{Mc} \mathrm{IE}$ & 136.1 & 0.89 & 10 & 199 & 10.4 & 0.12 & 0.9 & 1.4 \\
\hline $12 / 29 / 2013$ & $12: 38: 29.2$ & 43.7192 & -111.0988 & 2.8 ML MB & 135.9 & 3.80 & 26 & 109 & 10.7 & 0.11 & 0.5 & 2.9 \\
\hline $12 / 29 / 2013$ & $13: 41: 28.6$ & 43.7200 & -111.0860 & 1.8 ML IE & 137.0 & 6.22 & 15 & 154 & 10.3 & 0.09 & 0.7 & 1.6 \\
\hline $12 / 29 / 2013$ & $14: 05: 53.2$ & 43.7223 & -111.0778 & 1.7 Mc IE & 137.7 & 3.78 & 14 & 133 & 10.2 & 0.11 & 0.8 & 3.2 \\
\hline $12 / 29 / 2013$ & $14: 11: 19.9$ & 43.7165 & -111.0978 & $0.9 \mathrm{Mc} \mathrm{IE}$ & 136.0 & 4.13 & 9 & 199 & 10.4 & 0.05 & 0.9 & 2.8 \\
\hline $12 / 29 / 2013$ & $14: 16: 24.7$ & 43.7128 & -111.0918 & $2.0 \mathrm{Mc} \mathrm{IE}$ & 136.5 & 4.74 & 7 & 198 & 9.8 & 0.03 & 1.8 & 2.5 \\
\hline $12 / 29 / 2013$ & $14: 33: 10.0$ & 43.7018 & -111.1322 & $0.8 \mathrm{Mc} \mathrm{IE}$ & 133.2 & 2.92 & 8 & 160 & 11.1 & 0.12 & 2.3 & 11.5 \\
\hline $12 / 29 / 2013$ & $14: 40: 01.6$ & 43.7127 & -111.0715 & $0.8 \mathrm{Mc} \mathrm{IE}$ & 138.1 & 6.34 & 9 & 193 & 9.0 & 0.11 & 1.1 & 1.8 \\
\hline $12 / 29 / 2013$ & $14: 45: 07.5$ & 43.7127 & -111.1130 & $0.9 \mathrm{ML}$ IE & 134.8 & 2.00 & 7 & 203 & 10.8 & 0.10 & 2.6 & 14.9 \\
\hline $12 / 29 / 2013$ & $14: 58: 23.9$ & 43.7225 & -111.0923 & $0.8 \mathrm{Mc} \mathrm{IE}$ & 136.5 & 0.66 & 9 & 197 & 10.8 & 0.10 & 0.9 & 1.3 \\
\hline $12 / 29 / 2013$ & $14: 59: 28.9$ & 43.7125 & -111.0927 & $0.8 \mathrm{Mc} \mathrm{IE}$ & 136.4 & 4.22 & 10 & 198 & 9.8 & 0.07 & 0.9 & 2.7 \\
\hline $12 / 29 / 2013$ & $15: 10: 48.3$ & 43.7160 & -111.0138 & $0.7 \mathrm{Mc} \mathrm{IE}$ & 142.8 & 6.60 & 9 & 159 & 8.7 & 0.19 & 1.2 & 2.2 \\
\hline $12 / 29 / 2013$ & $16: 10: 22.7$ & 44.6653 & -113.6535 & $1.9 \mathrm{Mc} \mathrm{IE}$ & 132.7 & 6.67 & 11 & 238 & 44.1 & 0.18 & 1.9 & 4.1 \\
\hline $12 / 29 / 2013$ & $17: 11: 51.9$ & 43.7213 & -111.0747 & $0.8 \mathrm{Mc} \mathrm{IE}$ & 137.9 & 5.08 & 9 & 193 & 10.0 & 0.09 & 1.0 & 2.0 \\
\hline $12 / 29 / 2013$ & $17: 58: 13.8$ & 43.7213 & -111.0895 & $0.8 \mathrm{Mc} \mathrm{IE}$ & 136.7 & 3.24 & 10 & 196 & 10.5 & 0.12 & 1.1 & 5.8 \\
\hline $12 / 29 / 2013$ & $18: 10: 41.0$ & 43.7212 & -111.1213 & 1.6 Mc IE & 134.2 & 3.47 & 11 & 141 & 12.0 & 0.11 & 0.8 & 5.1 \\
\hline $12 / 29 / 2013$ & $18: 19: 28.2$ & 43.7178 & -111.0998 & $0.6 \mathrm{Mc} \mathrm{IE}$ & 135.9 & 2.09 & 7 & 199 & 10.6 & 0.11 & 3.9 & 15.3 \\
\hline $12 / 29 / 2013$ & $18: 22: 55.9$ & 43.7217 & -111.0892 & $0.8 \mathrm{Mc} \mathrm{IE}$ & 136.7 & 1.77 & 9 & 196 & 10.5 & 0.13 & 0.9 & 1.5 \\
\hline $12 / 29 / 2013$ & $18: 29: 20.6$ & 43.7198 & -111.0993 & $0.6 \mathrm{Mc} \mathrm{IE}$ & 135.9 & 3.63 & 9 & 199 & 10.8 & 0.10 & 1.0 & 4.2 \\
\hline $12 / 29 / 2013$ & $19: 10: 34.4$ & 43.7250 & -111.0552 & $0.8 \mathrm{Mc}$ IE & 139.5 & 6.15 & 8 & 183 & 9.9 & 0.06 & 0.9 & 1.8 \\
\hline $12 / 29 / 2013$ & $19: 15: 33.6$ & 43.7183 & -111.0992 & $2.5 \mathrm{Mc} \mathrm{IE}$ & 135.9 & 4.80 & 15 & 108 & 10.6 & 0.10 & 0.4 & 2.2 \\
\hline $12 / 29 / 2013$ & $19: 21: 14.5$ & 43.7205 & -111.0948 & $0.8 \mathrm{Mc}$ IE & 136.3 & 3.65 & 7 & 198 & 10.7 & 0.12 & 1.1 & 5.3 \\
\hline $12 / 29 / 2013$ & $19: 27: 21.2$ & 43.7165 & -111.0955 & $2.5 \mathrm{Mc} \mathrm{IE}$ & 136.2 & 5.00 & 13 & 110 & 10.3 & 0.08 & 0.4 & 2.1 \\
\hline $12 / 29 / 2013$ & $22: 45: 54.6$ & 43.7262 & -111.0852 & $0.9 \mathrm{Mc} \mathrm{IE}$ & 137.1 & 1.97 & 10 & 195 & 10.9 & 0.12 & 0.7 & 1.3 \\
\hline $12 / 29 / 2013$ & $22: 48: 20.6$ & 43.7217 & -111.0765 & 1.7 Mc IE & 137.8 & 5.06 & 11 & 133 & 10.1 & 0.12 & 0.9 & 2.3 \\
\hline $12 / 29 / 2013$ & 23:09:22.7 & 43.7203 & -111.0788 & 1.4 Mc IE & 137.6 & 1.92 & 11 & 134 & 10.0 & 0.14 & 0.8 & 1.4 \\
\hline $12 / 30 / 2013$ & 00:04:04.3 & 43.7182 & -111.0930 & 3.1 ML US & 136.4 & 5.62 & 23 & 111 & 10.4 & 0.10 & 0.4 & 1.5 \\
\hline $12 / 30 / 2013$ & $00: 08: 58.7$ & 43.7168 & -111.0885 & 1.6 Mc IE & 136.8 & 4.70 & 12 & 113 & 10.1 & 0.08 & 0.8 & 2.2 \\
\hline $12 / 30 / 2013$ & $00: 17: 44.1$ & 43.7202 & -111.0985 & $0.5 \mathrm{Mc} \mathrm{IE}$ & 136.0 & 2.36 & 9 & 199 & 10.8 & 0.12 & 1.0 & 12.0 \\
\hline $12 / 30 / 2013$ & $02: 46: 14.1$ & 43.7137 & -111.0447 & $0.7 \mathrm{Mc} \mathrm{IE}$ & 140.3 & 6.81 & 7 & 179 & 8.5 & 0.09 & 1.2 & 1.5 \\
\hline $12 / 30 / 2013$ & 03:00:13.2 & 43.7203 & -111.0758 & $0.8 \mathrm{Mc} \mathrm{IE}$ & 137.8 & 5.55 & 10 & 193 & 10.0 & 0.10 & 1.0 & 1.9 \\
\hline $12 / 30 / 2013$ & 04:35:00.8 & 43.7178 & -111.0887 & 1.0 Mc IE & 136.8 & 4.46 & 10 & 196 & 10.2 & 0.11 & 0.9 & 2.7 \\
\hline $12 / 30 / 2013$ & $05: 29: 31.6$ & 43.7082 & -111.0767 & $0.7 \mathrm{Mc}$ IE & 137.7 & 7.15 & 9 & 195 & 8.7 & 0.08 & 1.0 & 1.4 \\
\hline
\end{tabular}


Table C-2. Continued.

\begin{tabular}{|c|c|c|c|c|c|c|c|c|c|c|c|c|}
\hline ORIGIN & TIME & LAT N & LONG W & MAG-TYP & DIST & $z$ & NO & GAP & DMIN & RMS & $\mathrm{ERH}$ & ERZ \\
\hline $12 / 30 / 2013$ & $05: 41: 26.5$ & 43.7168 & -111.0990 & $2.1 \mathrm{Mc} \mathrm{IE}$ & 135.9 & 3.46 & 18 & 108 & 10.5 & 0.10 & 0.6 & 3.5 \\
\hline $12 / 30 / 2013$ & $06: 29: 54.2$ & 43.7150 & -111.0830 & $0.8 \mathrm{Mc}$ IE & 137.2 & 2.27 & 9 & 196 & 9.7 & 0.11 & 1.1 & 11.2 \\
\hline $12 / 30 / 2013$ & 07:11:39.6 & 43.7205 & -111.0888 & $0.8 \mathrm{Mc}$ IE & 136.8 & 2.80 & 9 & 196 & 10.4 & 0.09 & 1.0 & 6.8 \\
\hline $12 / 30 / 2013$ & $07: 48: 15.1$ & 43.7142 & -111.1000 & $1.9 \mathrm{Mc} \mathrm{IE}$ & 135.8 & 2.10 & 8 & 156 & 10.3 & 0.04 & 1.8 & 12.9 \\
\hline $12 / 30 / 2013$ & 09:49:03.4 & 43.7235 & -111.0860 & $0.8 \mathrm{Mc}$ IE & 137.0 & 0.05 & 10 & 195 & 10.6 & 0.15 & 1.1 & 0.8 \\
\hline $12 / 30 / 2013$ & $10: 03: 42.5$ & 43.7142 & -111.0565 & $0.9 \mathrm{Mc} \mathrm{IE}$ & 139.3 & 4.26 & 9 & 186 & 8.8 & 0.13 & 1.5 & 2.6 \\
\hline $12 / 30 / 2013$ & $10: 34: 22.5$ & 43.7170 & -111.0930 & 1.0 Mc IE & 136.4 & 0.17 & 12 & 155 & 10.3 & 0.09 & 0.8 & 0.7 \\
\hline $12 / 30 / 2013$ & $10: 44: 26.3$ & 43.7173 & -111.0895 & $2.1 \mathrm{Mc}$ IE & 136.7 & 1.81 & 17 & 154 & 10.1 & 0.09 & 0.5 & 0.9 \\
\hline $12 / 30 / 2013$ & $10: 54: 21.9$ & 43.7167 & -111.0850 & $0.8 \mathrm{Mc}$ IE & 137.0 & 3.77 & 10 & 196 & 9.9 & 0.11 & 1.0 & 3.7 \\
\hline $12 / 30 / 2013$ & $11: 22: 24.0$ & 43.7175 & -111.0897 & $0.8 \mathrm{Mc} \mathrm{IE}$ & 136.7 & 2.32 & 10 & 196 & 10.2 & 0.13 & 1.0 & 12.3 \\
\hline $12 / 30 / 2013$ & $11: 37: 43.4$ & 43.7200 & -111.0728 & $2.1 \mathrm{Mc} \mathrm{IE}$ & 138.0 & 5.29 & 14 & 119 & 9.8 & 0.11 & 0.6 & 1.8 \\
\hline $12 / 30 / 2013$ & $12: 11: 28.1$ & 43.8112 & -110.8338 & $0.9 \mathrm{Mc} \mathrm{IE}$ & 158.0 & 10.56 & 11 & 163 & 24.7 & 0.09 & 0.7 & 2.6 \\
\hline $12 / 30 / 2013$ & $12: 54: 51.2$ & 43.7147 & -111.0798 & $0.8 \mathrm{Mc} \mathrm{IE}$ & 137.4 & 4.07 & 10 & 195 & 9.5 & 0.14 & 1.1 & 3.3 \\
\hline $12 / 30 / 2013$ & $13: 10: 44.1$ & 43.7167 & -111.0868 & $1.0 \mathrm{Mc} \mathrm{IE}$ & 136.9 & 4.91 & 11 & 196 & 10.0 & 0.08 & 0.9 & 2.4 \\
\hline $12 / 30 / 2013$ & $13: 23: 32.6$ & 42.5253 & -111.8528 & 2.6 ML MB & 146.2 & 9.27 & 19 & 110 & 57.2 & 0.19 & 0.4 & 1.4 \\
\hline $12 / 30 / 2013$ & $13: 25: 55.6$ & 42.5220 & -111.8428 & 1.9 ML IE & 147.0 & 7.18 & 8 & 115 & 59.7 & 0.12 & 0.5 & 2.7 \\
\hline $12 / 30 / 2013$ & $15: 08: 42.7$ & 43.7120 & -111.0848 & 1.0 Mc IE & 137.0 & 6.77 & 9 & 196 & 9.4 & 0.10 & 0.9 & 1.5 \\
\hline $12 / 30 / 2013$ & $15: 10: 55.1$ & 43.7197 & -111.0767 & 1.0 Mc IE & 137.7 & 2.14 & 11 & 193 & 9.9 & 0.12 & 0.9 & 14.0 \\
\hline $12 / 30 / 2013$ & $15: 15: 40.7$ & 43.7145 & -111.0883 & $0.8 \mathrm{Mc} \mathrm{IE}$ & 136.8 & 2.06 & 9 & 197 & 9.8 & 0.11 & 1.0 & 15.5 \\
\hline $12 / 30 / 2013$ & $16: 03: 27.4$ & 43.7203 & -111.0632 & $1.7 \mathrm{Mc} \mathrm{IE}$ & 138.8 & 0.22 & 15 & 151 & 9.6 & 0.11 & 0.8 & 0.6 \\
\hline $12 / 30 / 2013$ & $16: 10: 33.7$ & 43.7207 & -111.0947 & $0.9 \mathrm{Mc}$ IE & 136.3 & 2.26 & 10 & 198 & 10.7 & 0.09 & 0.9 & 12.0 \\
\hline $12 / 30 / 2013$ & $16: 43: 36.0$ & 43.7240 & -111.0767 & 1.2 Mc IE & 137.8 & 0.15 & 14 & 193 & 10.3 & 0.12 & 0.6 & 0.7 \\
\hline $12 / 30 / 2013$ & $17: 40: 31.2$ & 43.7207 & -111.0850 & $1.0 \mathrm{Mc} \mathrm{IE}$ & 137.1 & 2.36 & 8 & 196 & 10.3 & 0.13 & 1.3 & 13.5 \\
\hline $12 / 30 / 2013$ & $17: 46: 13.1$ & 43.7072 & -111.0373 & $0.6 \mathrm{Mc} \mathrm{IE}$ & 140.8 & 8.90 & 6 & 175 & 7.7 & 0.08 & 1.3 & 1.9 \\
\hline $12 / 30 / 2013$ & 18:09:17.5 & 43.7208 & -111.0842 & $0.6 \mathrm{Mc} \mathrm{IE}$ & 137.1 & 4.40 & 11 & 195 & 10.3 & 0.12 & 1.0 & 3.2 \\
\hline $12 / 30 / 2013$ & $23: 28: 46.0$ & 43.7227 & -111.0705 & 1.2 ML IE & 138.2 & 0.03 & 10 & 192 & 10.0 & 0.11 & 0.7 & 0.8 \\
\hline $12 / 31 / 2013$ & $01: 25: 18.4$ & 43.7150 & -111.0452 & $0.2 \mathrm{Mc}$ IE & 140.2 & 6.44 & 6 & 212 & 8.7 & 0.07 & 2.7 & 1.7 \\
\hline $12 / 31 / 2013$ & 01:52:54.4 & 43.7183 & -111.0815 & $0.9 \mathrm{Mc}$ IE & 137.3 & 2.84 & 12 & 195 & 9.9 & 0.12 & 1.0 & 6.6 \\
\hline $12 / 31 / 2013$ & $02: 04: 47.7$ & 43.7207 & -111.0617 & $0.9 \mathrm{Mc} \mathrm{IE}$ & 138.9 & 6.66 & 9 & 188 & 9.6 & 0.07 & 1.1 & 1.5 \\
\hline $12 / 31 / 2013$ & $02: 38: 12.9$ & 43.7238 & -111.0927 & 2.1 ML IE & 136.5 & 0.66 & 18 & 112 & 10.9 & 0.10 & 0.5 & 0.9 \\
\hline $12 / 31 / 2013$ & $02: 54: 26.0$ & 43.7238 & -111.0845 & 1.0 Mc IE & 137.1 & 0.40 & 11 & 195 & 10.6 & 0.11 & 0.9 & 0.7 \\
\hline $12 / 31 / 2013$ & $03: 26: 08.0$ & 43.7202 & -111.0613 & 1.2 Mc IE & 139.0 & 0.03 & 11 & 187 & 9.5 & 0.15 & 1.0 & 0.7 \\
\hline $12 / 31 / 2013$ & 04:38:17.8 & 42.7223 & -111.3422 & $2.2 \mathrm{Mc} \mathrm{IE}$ & 156.1 & 7.11 & 14 & 109 & 20.4 & 0.07 & 0.6 & 3.0 \\
\hline $12 / 31 / 2013$ & $05: 56: 36.2$ & 43.7205 & -111.0805 & $0.9 \mathrm{Mc}$ IE & 137.4 & 2.24 & 12 & 195 & 10.1 & 0.11 & 1.0 & 12.6 \\
\hline $12 / 31 / 2013$ & $06: 29: 33.2$ & 43.7238 & -111.0945 & $2.6 \mathrm{Mc} \mathrm{IE}$ & 136.3 & 2.23 & 9 & 198 & 11.0 & 0.09 & 2.4 & 13.0 \\
\hline $12 / 31 / 2013$ & $06: 32: 06.9$ & 43.7178 & -111.0535 & $0.5 \mathrm{Mc} \mathrm{IE}$ & 139.6 & 6.62 & 9 & 183 & 9.1 & 0.10 & 1.3 & 1.5 \\
\hline $12 / 31 / 2013$ & $07: 41: 31.9$ & 43.7193 & -111.1008 & $0.9 \mathrm{Mc} \mathrm{IE}$ & 135.8 & 2.10 & 11 & 199 & 10.8 & 0.17 & 1.0 & 18.8 \\
\hline $12 / 31 / 2013$ & 08:03:07.5 & 43.7213 & -111.0760 & $0.9 \mathrm{Mc}$ IE & 137.8 & 4.92 & 12 & 193 & 10.0 & 0.12 & 0.9 & 2.3 \\
\hline $12 / 31 / 2013$ & 09:59:47.7 & 43.7200 & -111.0707 & $0.8 \mathrm{Mc} \mathrm{IE}$ & 138.2 & 0.82 & 13 & 132 & 9.8 & 0.12 & 0.7 & 0.5 \\
\hline $12 / 31 / 2013$ & $10: 04: 56.7$ & 43.7210 & -111.0930 & $2.2 \mathrm{Mc} \mathrm{IE}$ & 136.4 & 2.03 & 20 & 111 & 10.6 & 0.11 & 0.4 & 15.6 \\
\hline $12 / 31 / 2013$ & $15: 45: 48.1$ & 43.7215 & -111.0878 & 1.2 ML IE & 136.8 & 3.50 & 12 & 196 & 10.5 & 0.15 & 1.0 & 4.9 \\
\hline $12 / 31 / 2013$ & $15: 48: 18.9$ & 43.7210 & -111.0740 & $0.7 \mathrm{Mc} \mathrm{IE}$ & 137.9 & 3.69 & 8 & 193 & 10.0 & 0.06 & 0.9 & 3.3 \\
\hline $12 / 31 / 2013$ & $16: 53: 02.2$ & 43.7115 & -111.0507 & $0.6 \mathrm{Mc} \mathrm{IE}$ & 139.8 & 9.40 & 9 & 183 & 8.4 & 0.07 & 1.1 & 1.1 \\
\hline $12 / 31 / 2013$ & $17: 35: 22.5$ & 43.7255 & -111.0940 & $0.9 \mathrm{Mc} \mathrm{IE}$ & 136.4 & 2.00 & 12 & 197 & 11.1 & 0.13 & 1.0 & 16.6 \\
\hline $12 / 31 / 2013$ & 23:39:05.9 & 43.7228 & -111.0945 & $0.9 \mathrm{Mc} \mathrm{IE}$ & 136.3 & 3.14 & 12 & 198 & 10.9 & 0.13 & 1.0 & 5.8 \\
\hline
\end{tabular}

